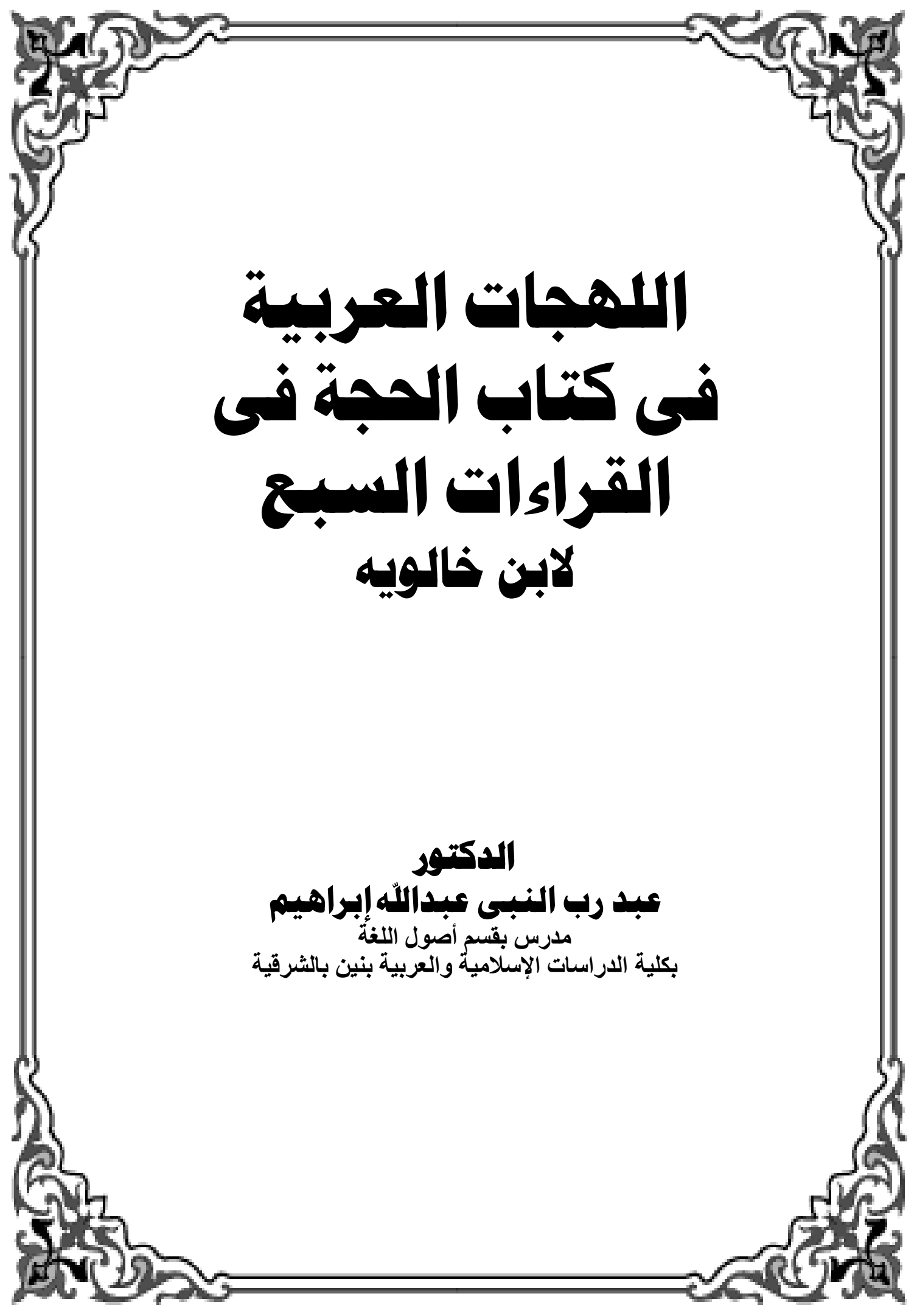




$$
\text { بسم الله الرحن الرحيم }
$$

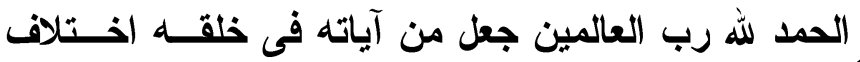

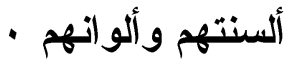

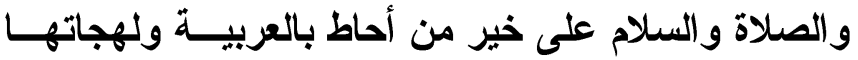

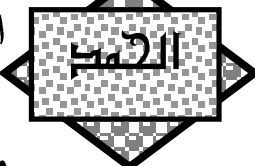

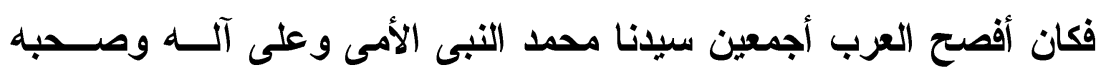

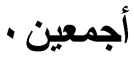

\section{وبعر ...}

فمما لا شك فيه أن البحث فى اللهجات العربية وبيــان خصائصــها وسماتها أمر بالغ الأهمية إذ إنه يوقفنا على أصول اللغة التها العربية وجذورها

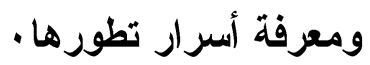

والواقع أن المكتبة العربية فى حاجة ماسة إلى مثل هــــه البحــوث التى تعد لبنة أساسية فى صرح الثقافة اللغوية الثاميخ.

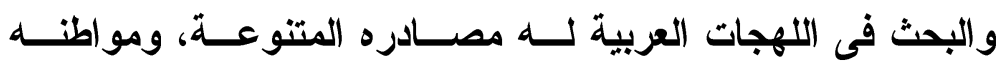

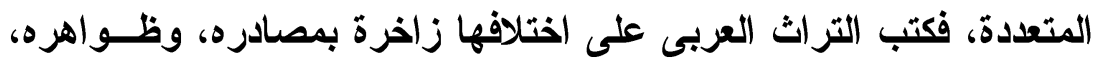
وملامحه. .

وكتاب "العجة فى القراعات السبع" لابن خالويه يحتل مكانة رفيعـة بين كتب التراث، فقد اثتمل على كثير من اللهجات العربية وهو من الكتب التبن

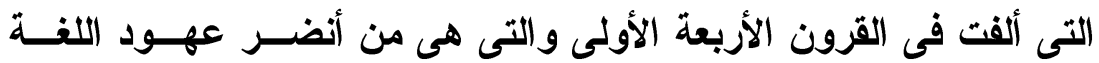

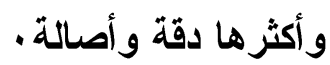

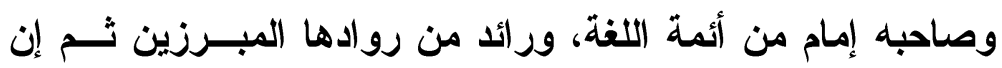
اللهجات الواردة فيه تزخر بثروة لغوية ضخمة جديرة بالبحث والدار اســـة و المناقشة .

وقد قمت باستقراء تام لهذا الكتاب، وأنعمت النظر فيـهـه واسـتنبط

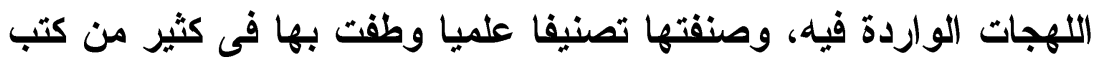

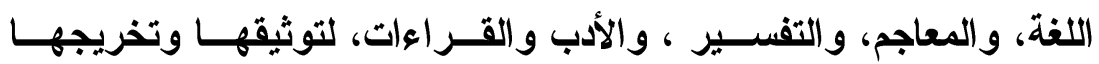

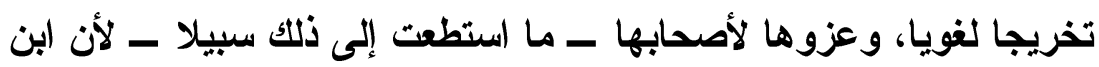


خالويه لم ينسب كثير ا منها لأصحابها، فقد كان يكتفى بقوله : "وهذه لغــة

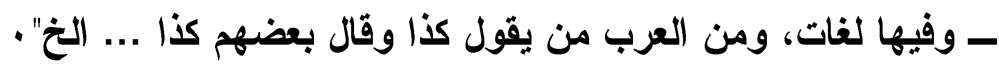

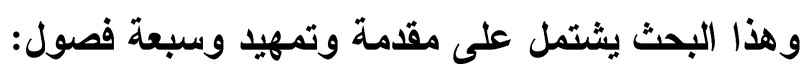

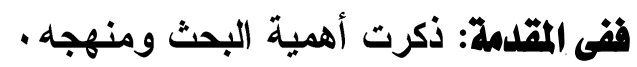

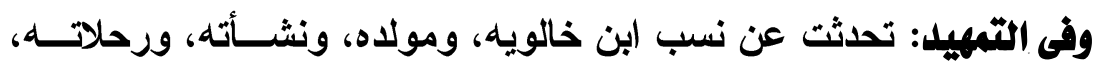

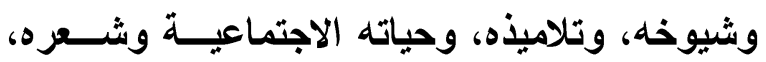

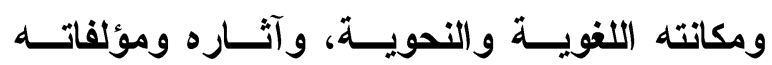

$$
\text { ووفاته و وناته }
$$

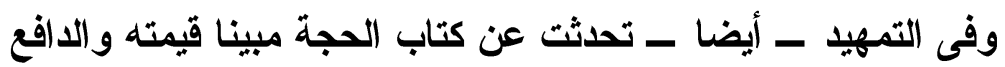

لتأليفه، ومصادره، ومنهجه ، والمآخذ عليه.

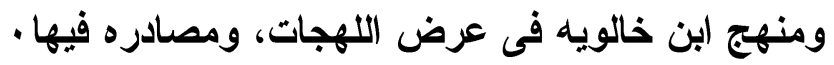

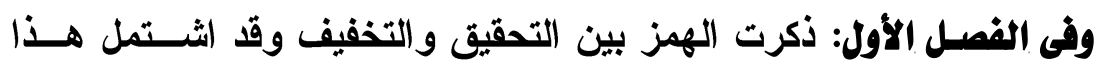

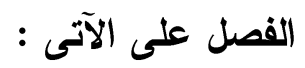

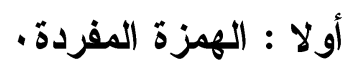

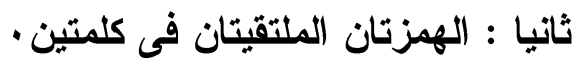

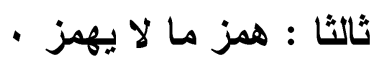

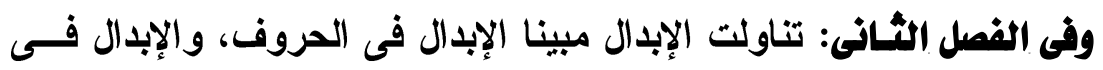

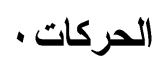

وفى الفصل الثالث: تحدثت عن التقريب بين الأصوات، وقـــ تضــمن هــــا

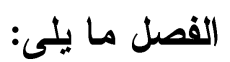

$$
\begin{aligned}
& 1 \\
& \text { r } \\
& \text { - r - الإشمام - r }
\end{aligned}
$$

وفى الفصل الرابـع: ذكرت تقصير الحركة، وقد اشتمل هذا الفصل على مــا

$$
\text { يلحى: }
$$

أولا: تقصير الحركة الطويلة.

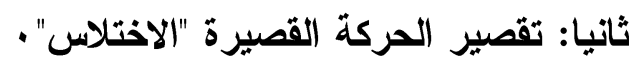


وفى الفصل الخامس: تناولت الحذف ، وقد تضمن هذا الفصل ما يلى:

$$
1 \text { - } 1
$$

وفى الفصل السادس: تعدثت عن الظواهر الصرفية وقد اثتثمل هذا الفصـل

$$
\begin{aligned}
& \text { على ما يأتى: } \\
& \text { أولا: البنية بين الطول والقصر - } \\
& \text { ثاتيا: القلب المكانى }
\end{aligned}
$$

وفى الفمسل السـابع : ذكرث الظواهر النحوية ، وقد تضمن هذا الفصل مــا

$$
\text { يلى : نكرث: }
$$

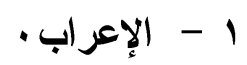

$$
\begin{aligned}
& \text { r - إعراب المثى بالألف. }
\end{aligned}
$$

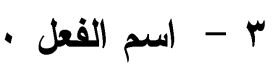

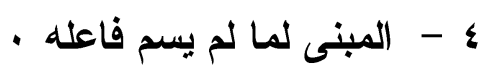

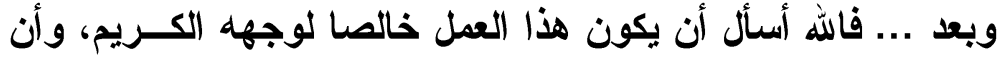

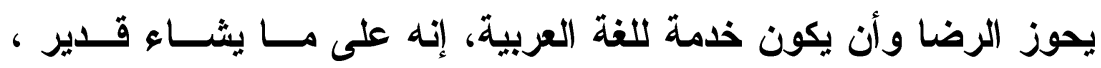

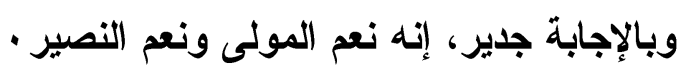

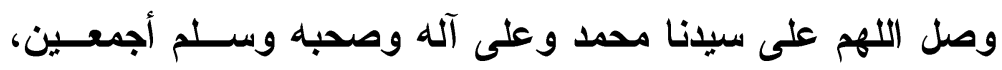

\section{الباحث}

$$
\text { وآخر دعوانا أن الحمد لله رب العالمين . }
$$




\section{التمهيد

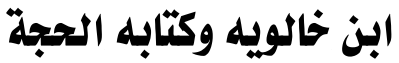

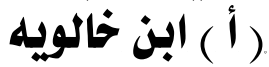

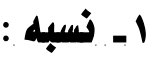

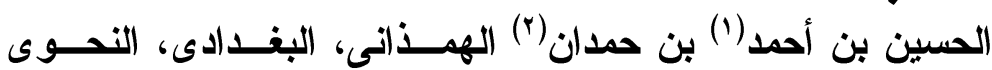

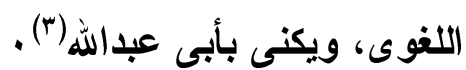

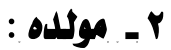

لم تتعرض كتب الرواة لسنة مولده، وإن تعرضت لسنة وفاته(؛) .

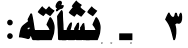

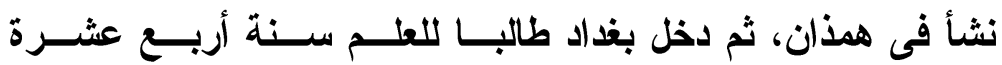

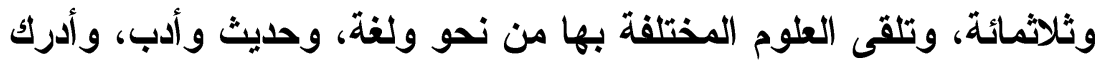

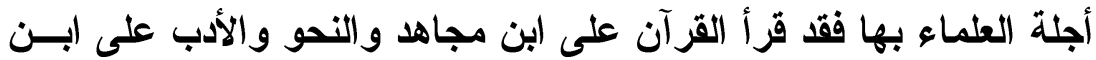

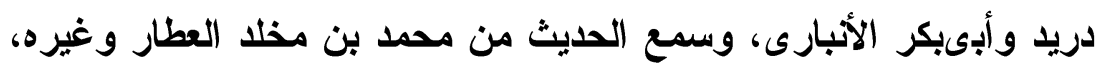

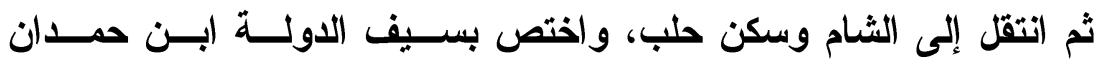
وأولاده، وأدب بعض أولاده، وتصدر بحلب وميا فارقين وحمــ لــ للإفــادة

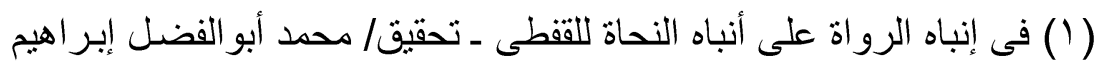

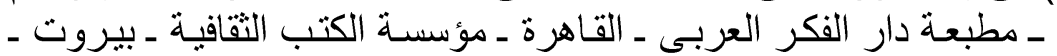

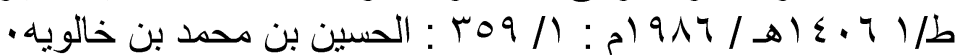

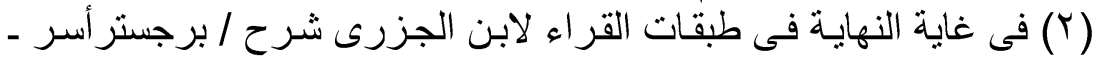

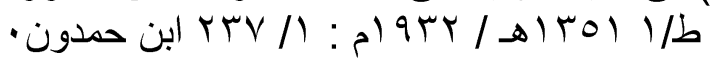

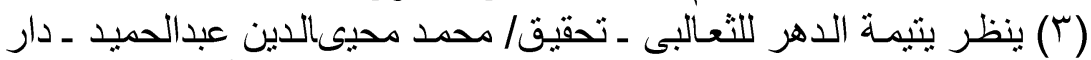

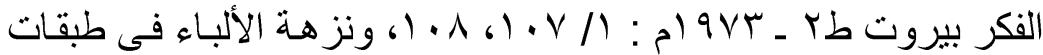

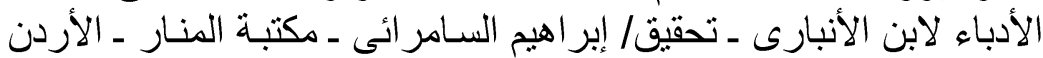

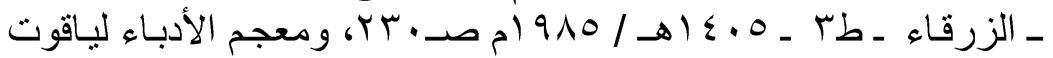

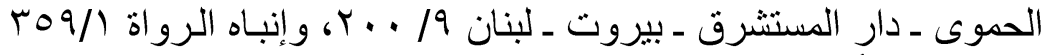

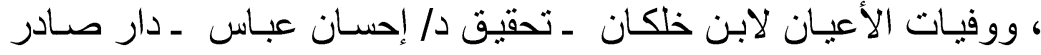

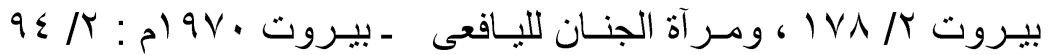

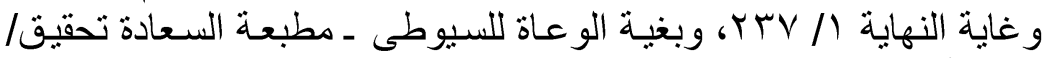

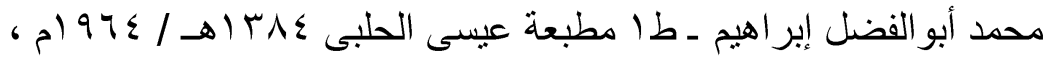
. or. ، 0 r $9 / 1$

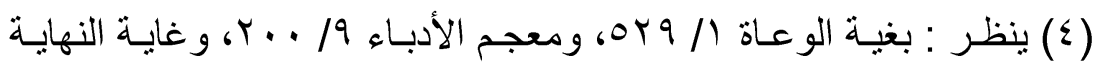


و التصنيف، وعاث بعد سيف الدولة فى صحبة ولاه شريف وغيره من آل حمدان (1)

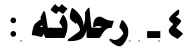

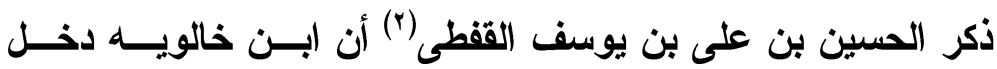

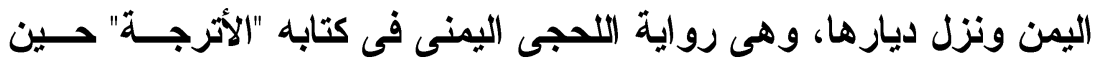

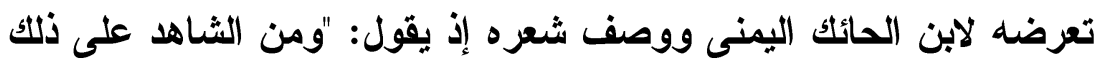

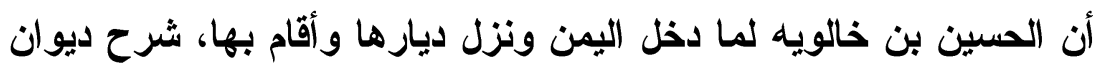
ابن الحائك، وعنى به، وذكر غريبه وإعرابه" .

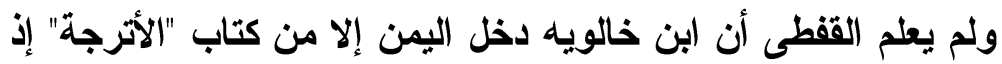

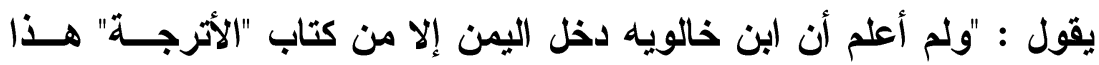

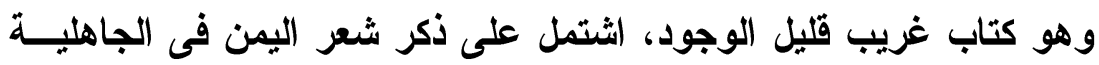

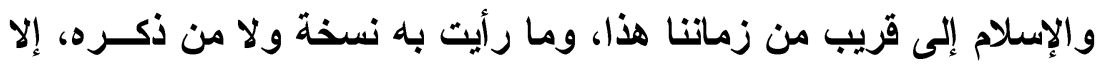

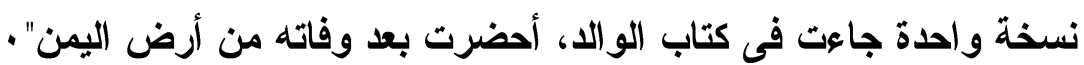

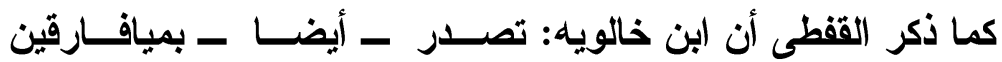
و"حمص" للإفادة والتصنيف، وأخير الستقر به المقام فى "حلب" حتى وافهاه

\section{هـ ـ شيوخه وأساتدته :}

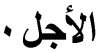

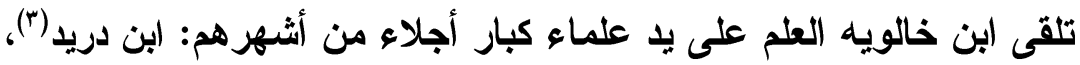

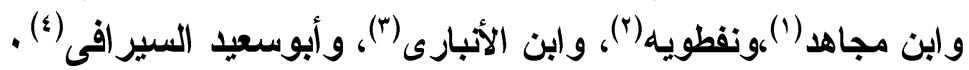

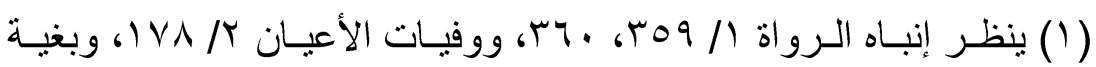

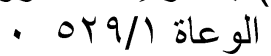

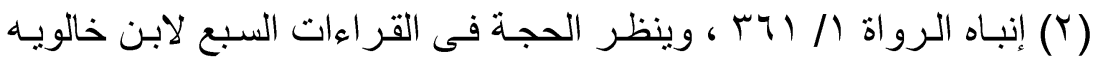

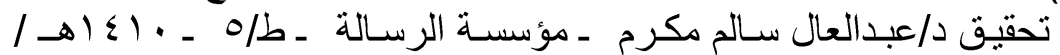

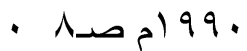

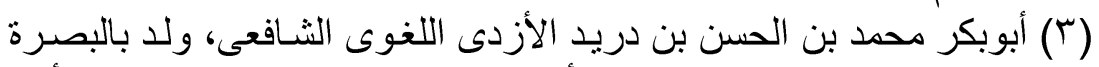

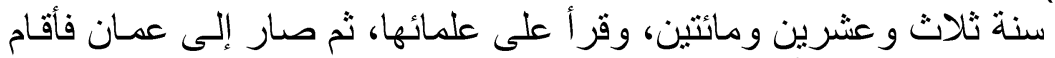

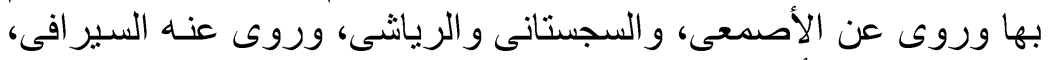

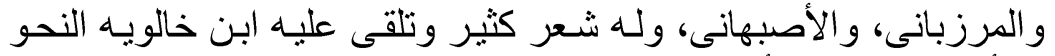

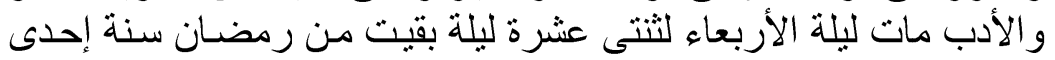

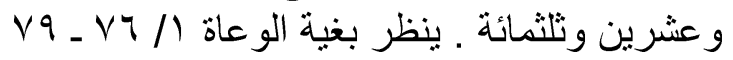




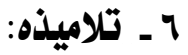

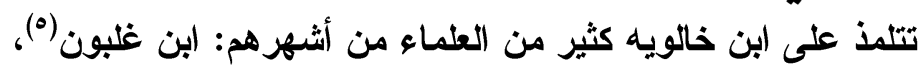

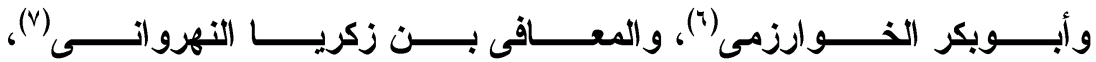

(1) أحمد بن موسى بـن العباس بـن مجاهد: أبوبكر تلقى ابن خالويـه عليه

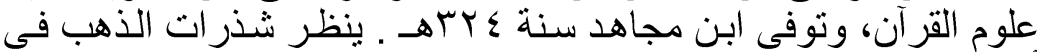

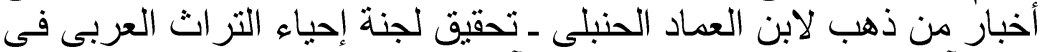

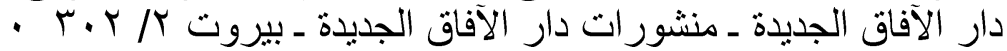

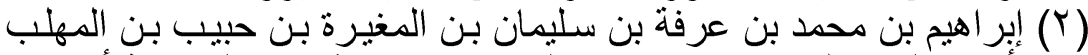

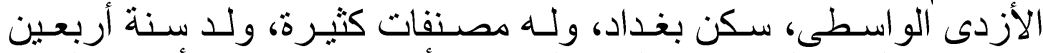

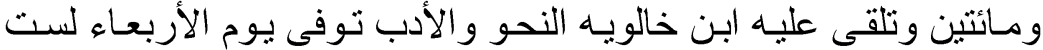

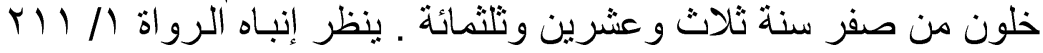

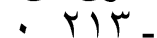

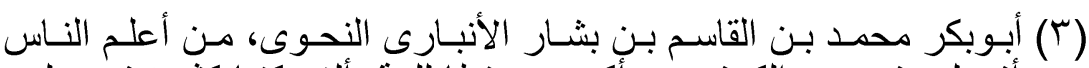

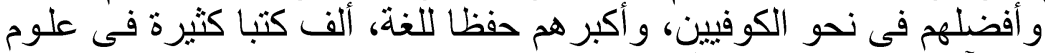

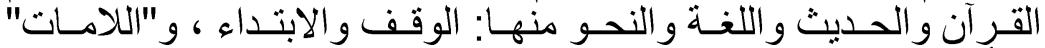

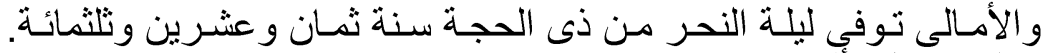

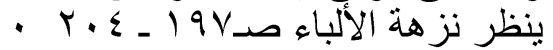

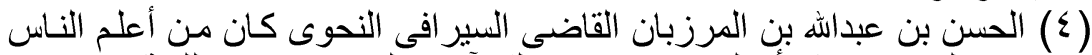

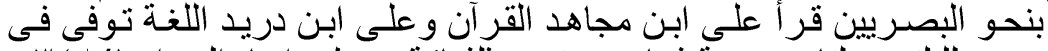

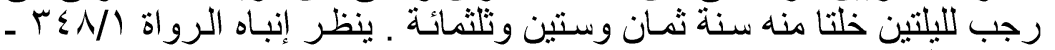

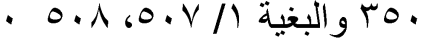

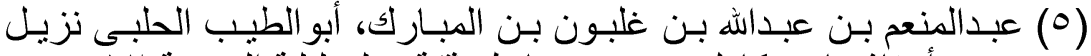

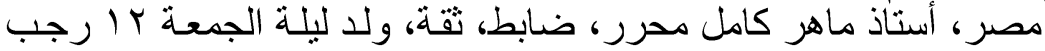

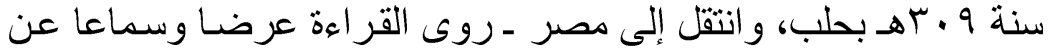

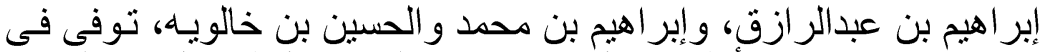

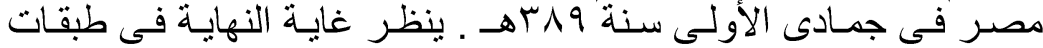
- القر اءه

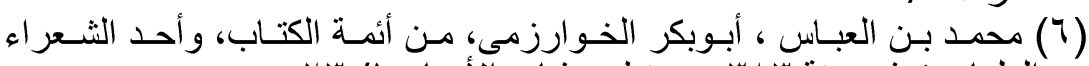

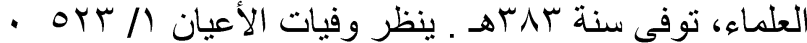

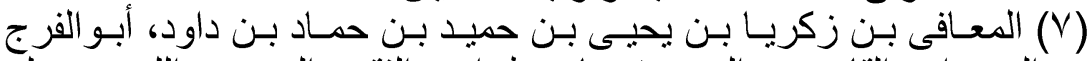

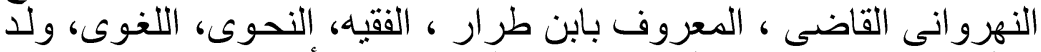

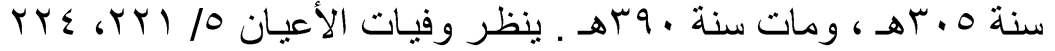




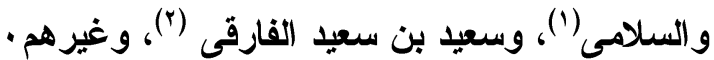

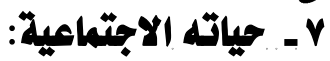

كان ابن خالويه فقير ا معوزا وقد طلب المال ليسد العوز ويبعد الفقر

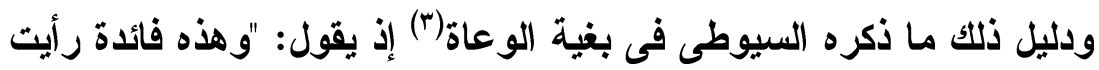

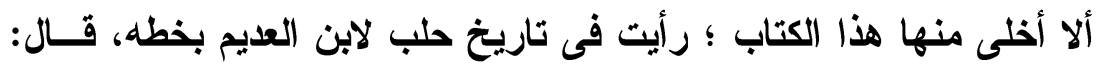

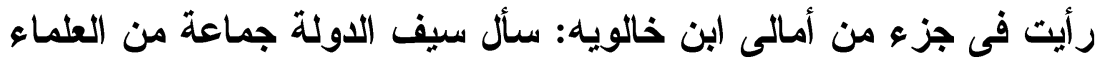

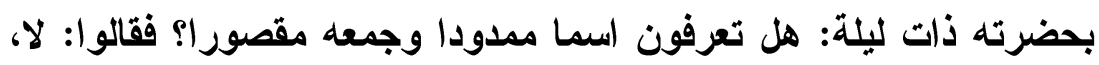

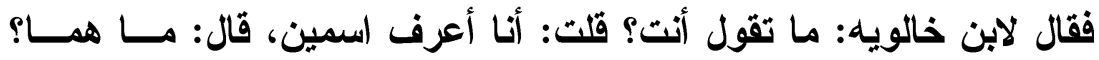

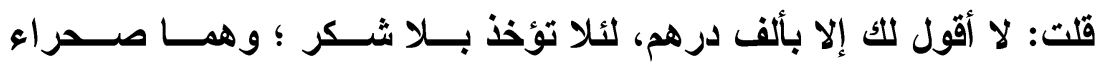

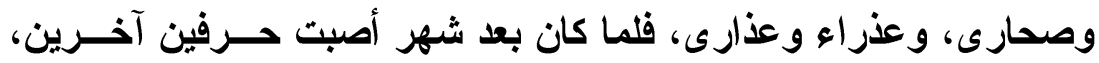

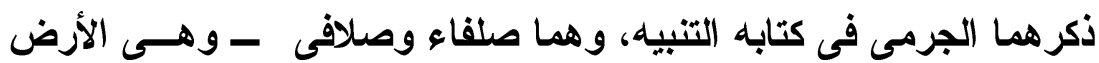

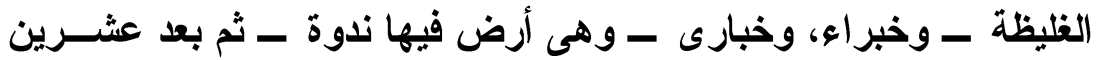

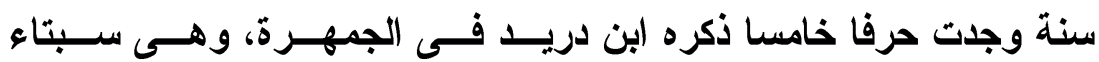
وسباتى، وهى الأرض الخشنة" .

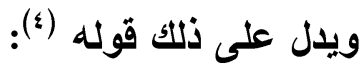

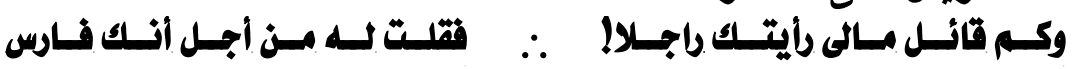

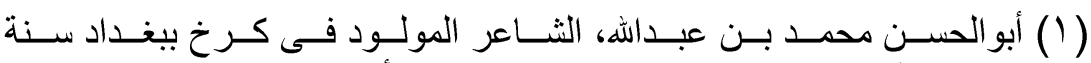

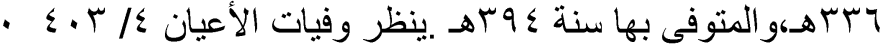

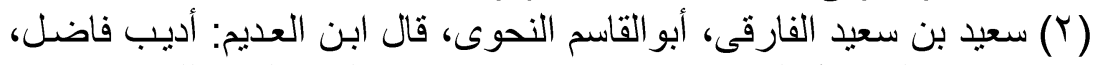

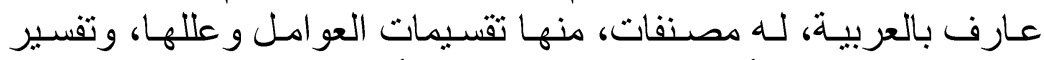

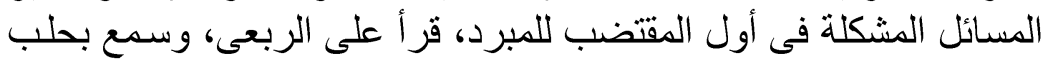

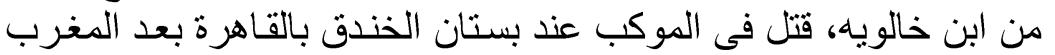

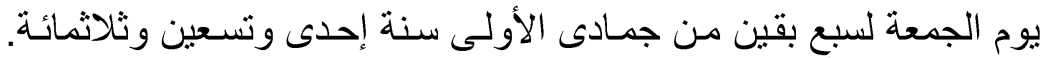

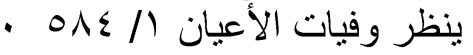

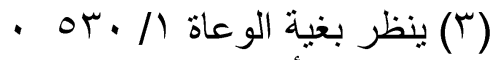

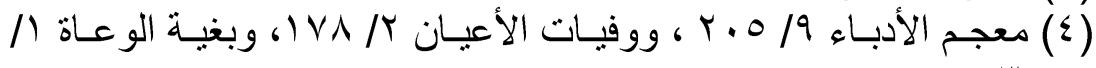




$$
\text { ويدل على ذلك - أيضا - قولهه (1) : }
$$

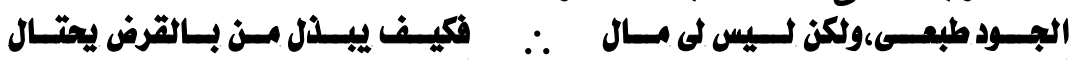

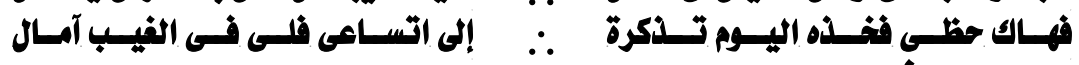

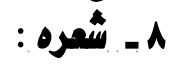

كان لابن خالويه شعر مليح ولكنه قليل فهو الأى قال (؟) :

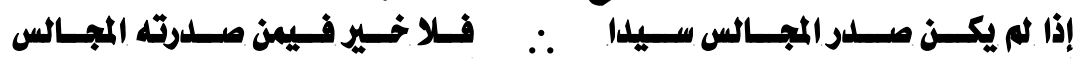

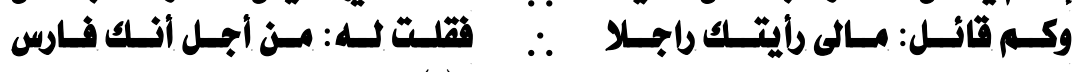

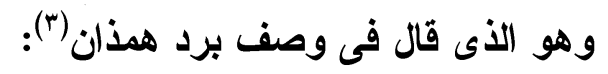

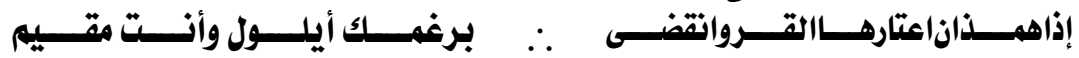

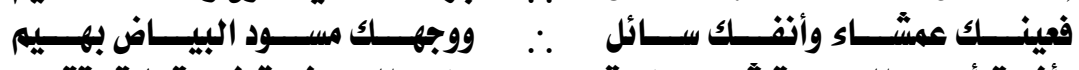

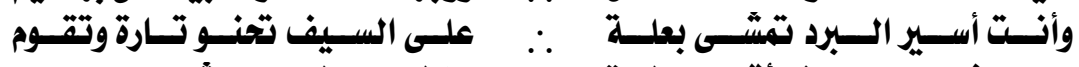

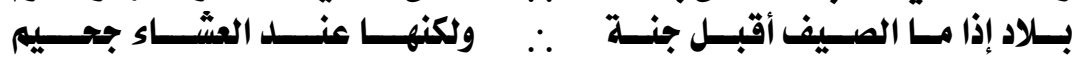

$$
\text { وهو القائل عن قد محبوبه (๕): }
$$

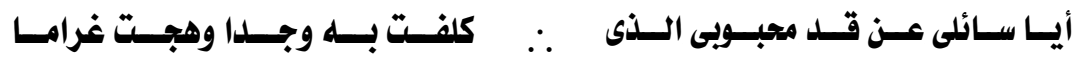

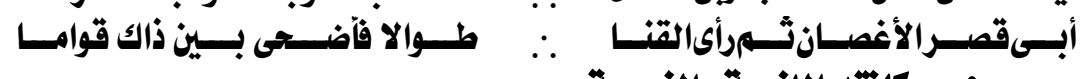
9 - مكاتثه اللفوية والنعوية:

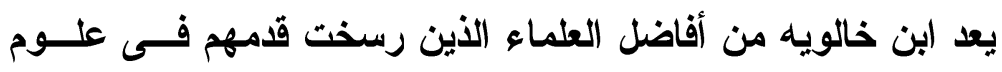

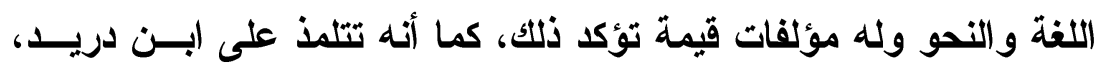

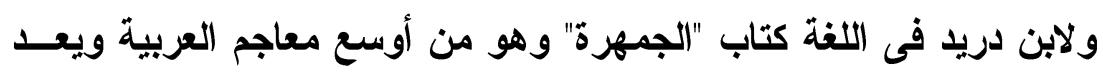

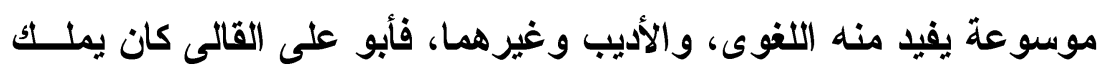

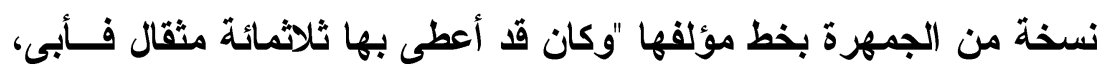

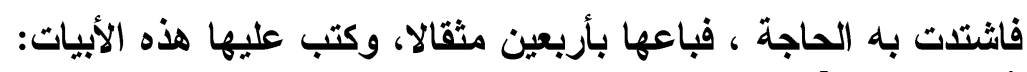

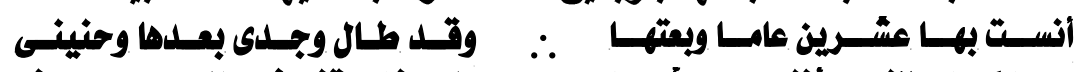

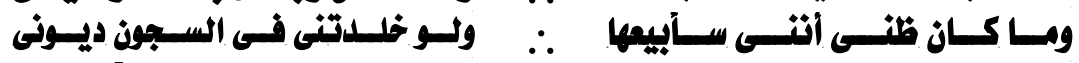

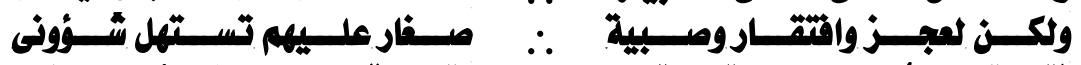

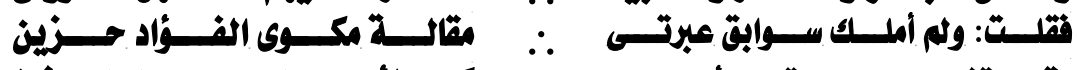

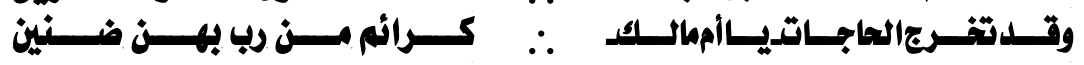

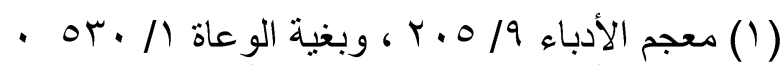

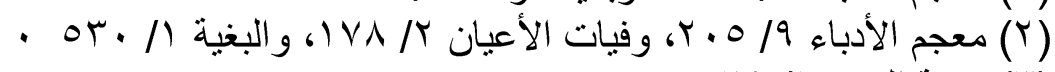

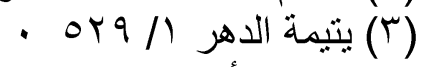

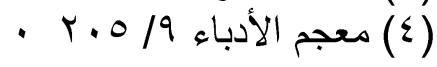


قال: فأرسلها الأى اثتر اها، وأرسل معها أربعين دينــارا أخــى (1)

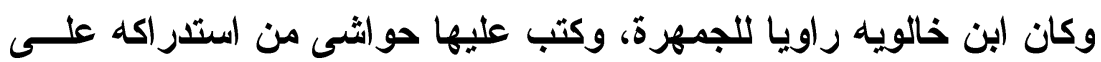

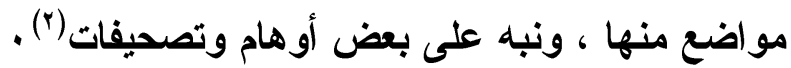

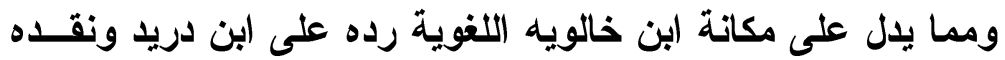

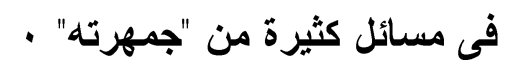

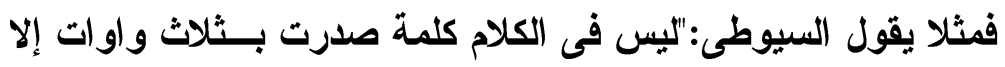

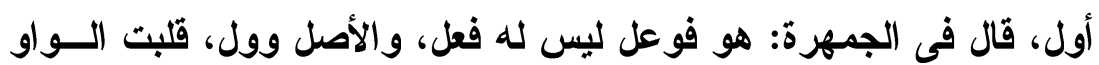

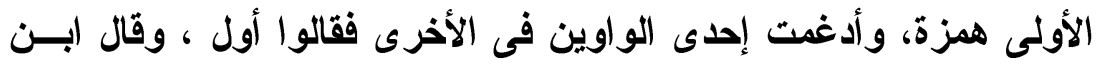

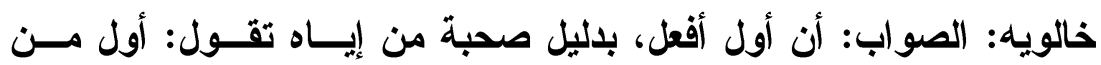
كذا"(r) (") وقد رد ـ أيضا ـ على ابن دريد فى جمهرته حينما قال: "لم يجسئ

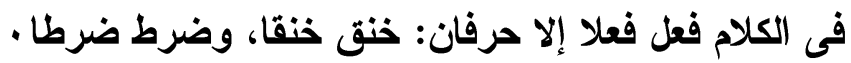

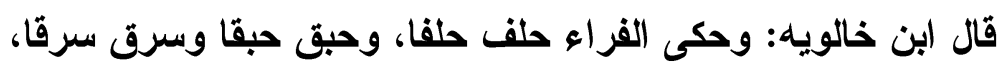

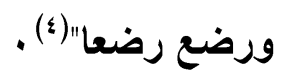

كما أن ابن خالويه كان يتمتع بحس مرهف فى تذوق أسرار اللغــة

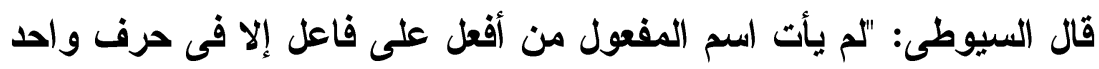

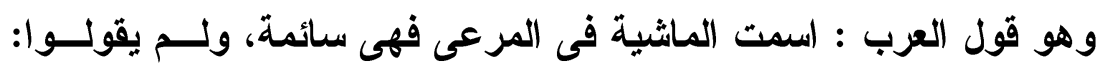

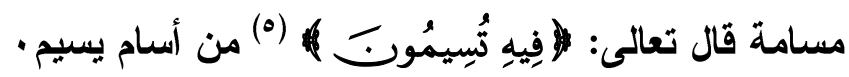

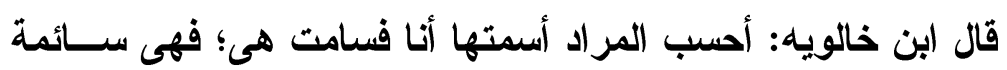

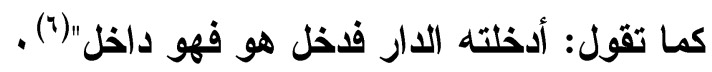

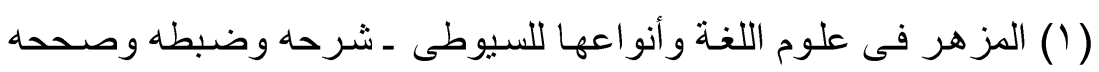

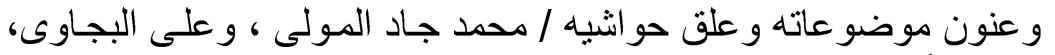

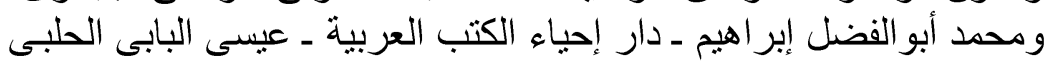




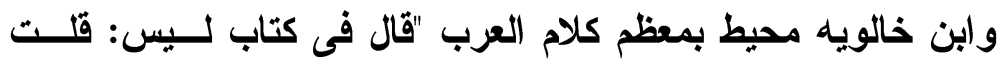

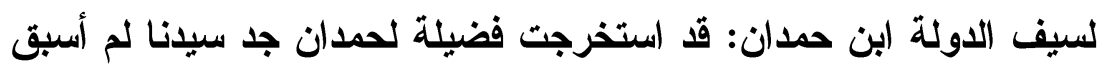

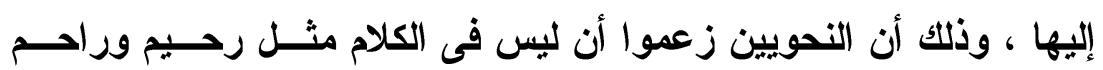

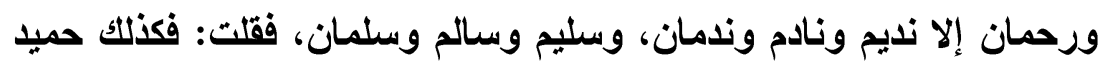

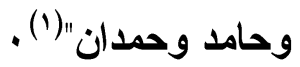

واستشهد ابن خالويه بلغة الأعراب إذ يقول فى شرح الدريدية: "كل

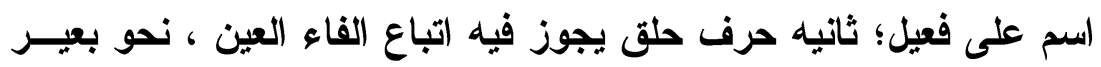

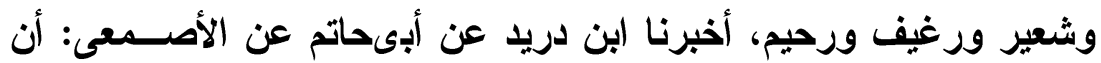

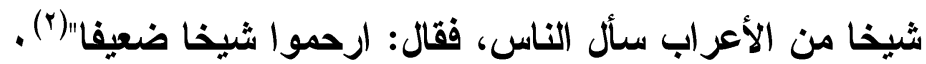

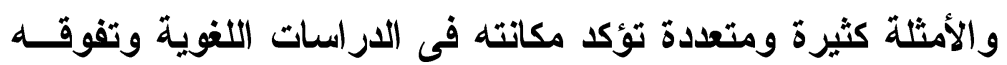

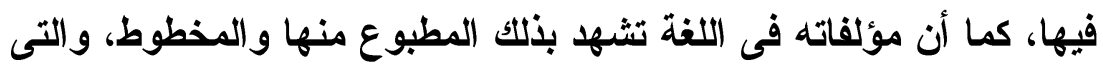
سنذكرها عقب هذا الموضوع، إن شاء الله تعالى، وبقى هنا سؤال هل كله كان

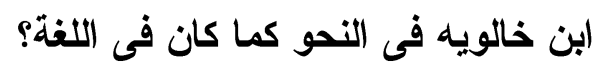

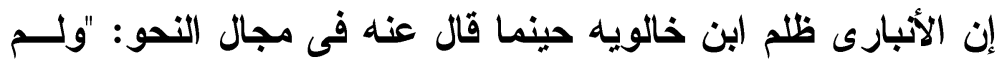

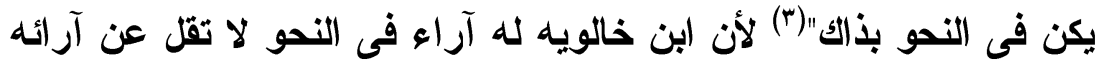

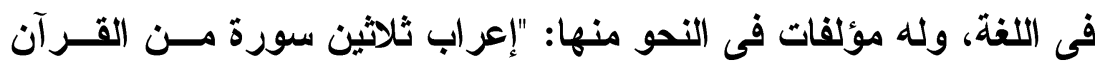

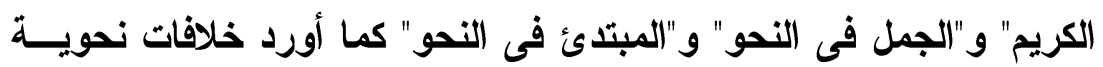

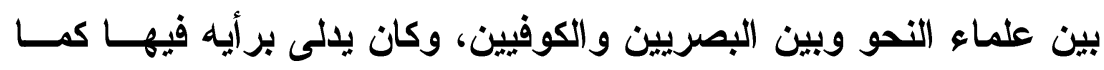

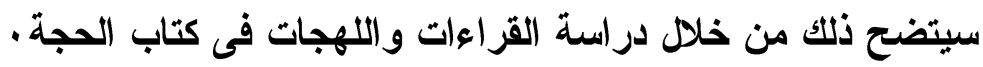
ولعل السبب فى عدم اشتهار ابن خالويه بالنحو هو: أنه كان يؤمن:

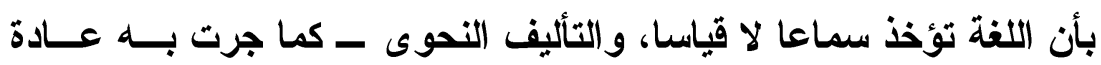

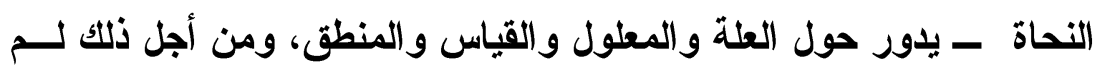

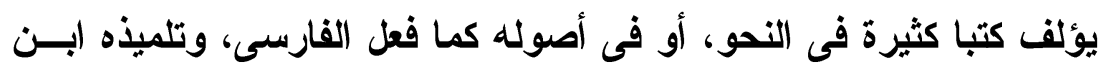

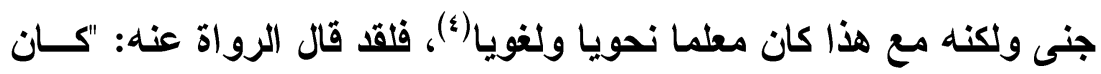

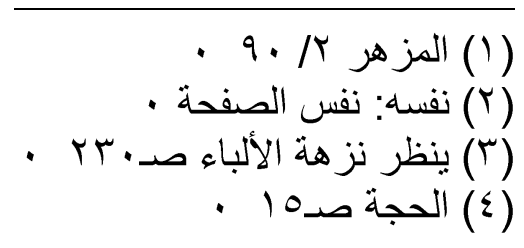


إمامـا أحد أفر اد الدهر فى كل قسم من أقسام العلـــم والأدب وكانـــت إليــهـ

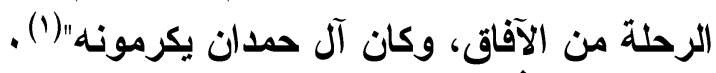

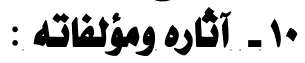

لقد خلف العلامة ابن خالويه وراءه كتبا كثيرة نفيسة ومؤلفات قيمة

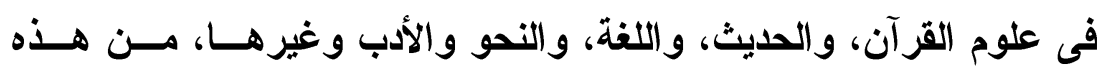

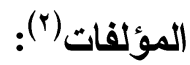

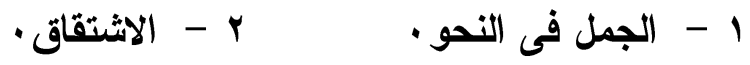

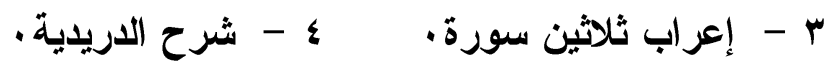

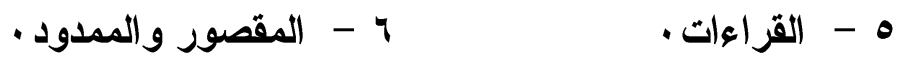

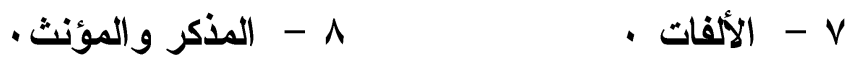

$$
\begin{aligned}
& \text {. }
\end{aligned}
$$

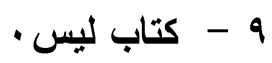

$$
\begin{aligned}
& 11 \\
& \text { r r ا تقفية ما اختلف لفظه واتفق معناه. } \\
& \text { rا }
\end{aligned}
$$

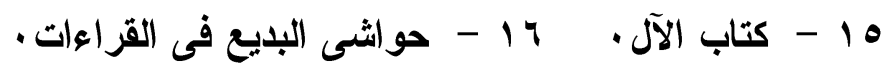

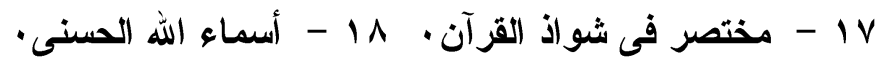

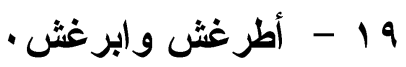

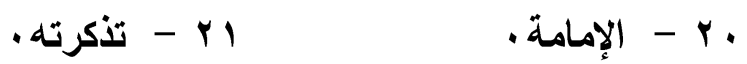

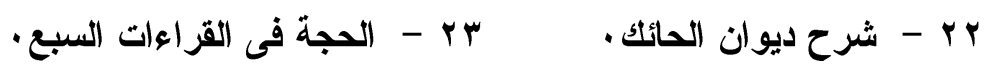

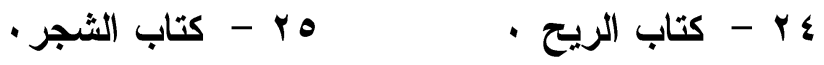

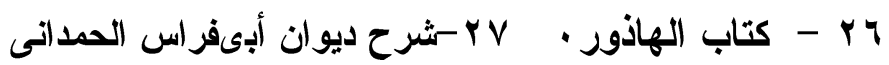

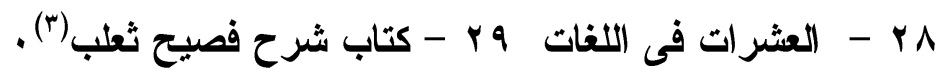

$$
\begin{aligned}
& 11 \text { - وضاته: }
\end{aligned}
$$

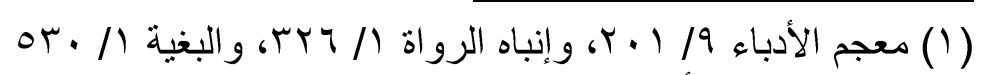

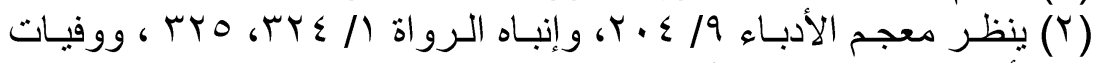

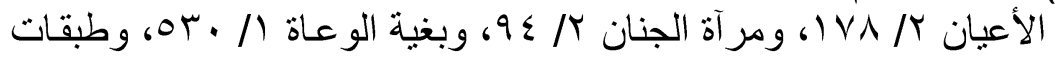

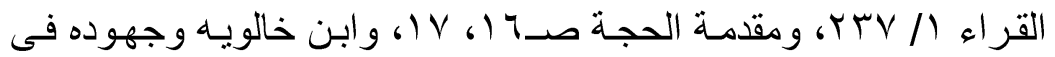

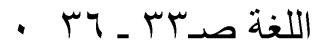

(r) ينظر المزهر / / آץ ، ، ونقل عنه السيوطى فى مواطن كثيرة. 
توفى العلامة ابن خالويه ـ رحمه الله ـ بحلب عام سبعين وثُلاثمائة

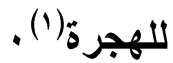

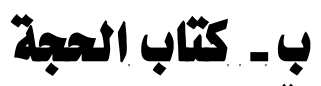

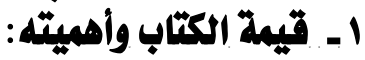

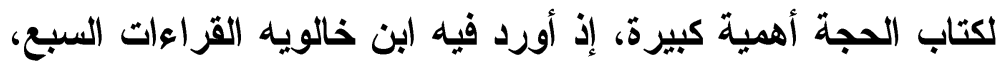

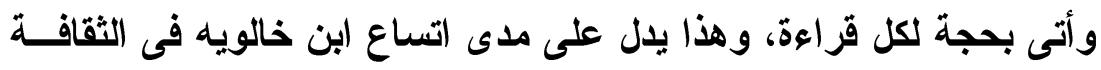

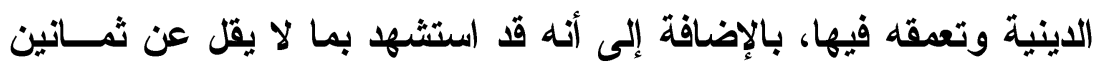

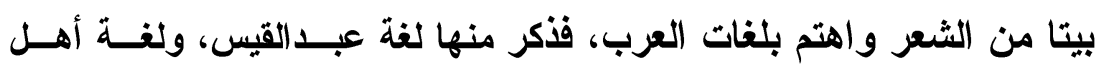

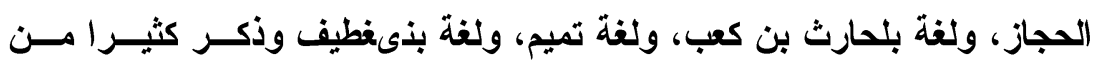

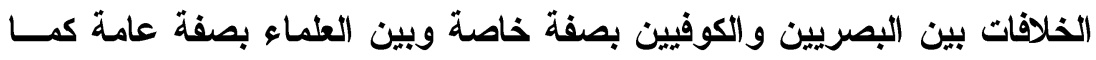

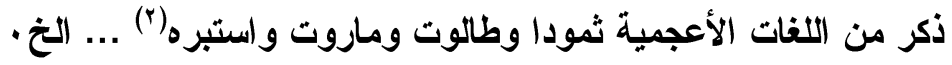

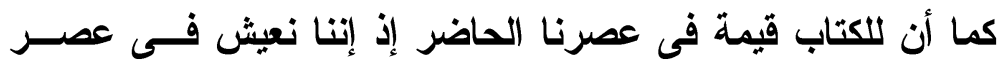

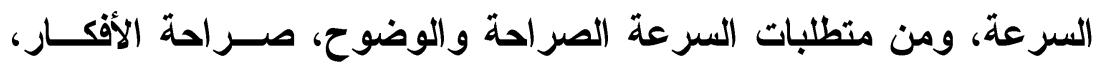

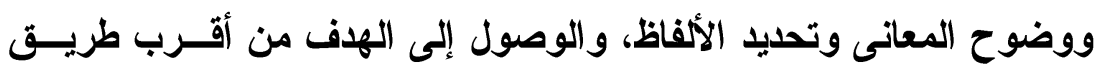

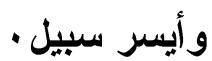

وكل ذلك تجده فى الحجة متمثلا فى كل صفحة من صفحاته بل فـى كل سطر من سطوره("). (5).

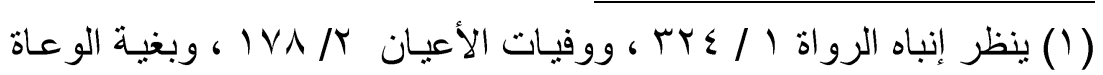
- Or./1

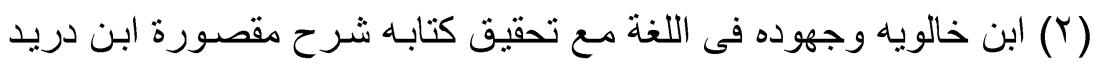

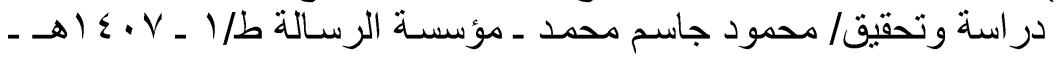
- 90 _ 94 (1919

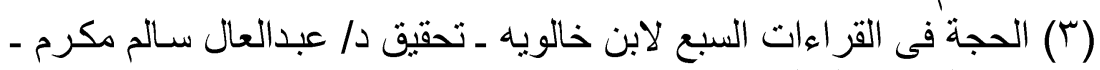

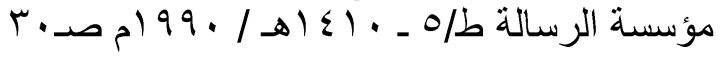




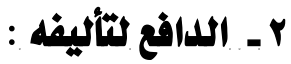

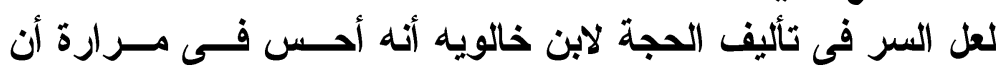
كتاب أبىعلى لا ينتفع به الخاصة فضلا عن العامة، فحفزه ذلك إلى تــأليف

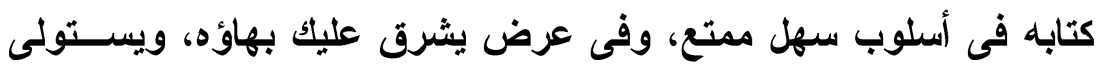

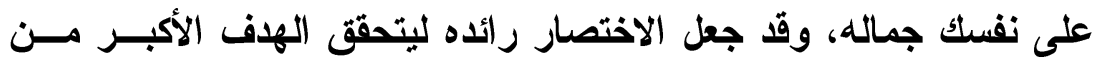

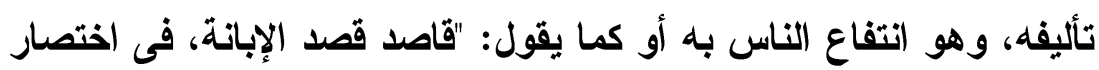

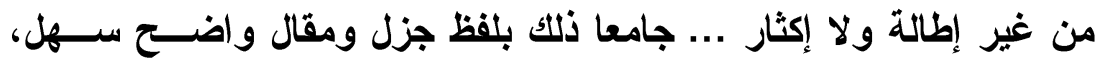

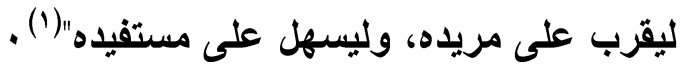

$$
\begin{aligned}
& \text { r. }
\end{aligned}
$$

نقل ابن خالويه كثيرا من الأقوال عن النحاة واللغــويين بصــريين

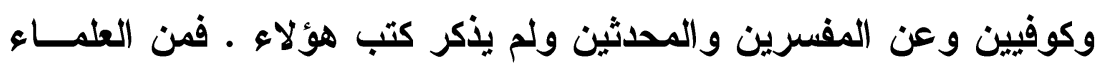

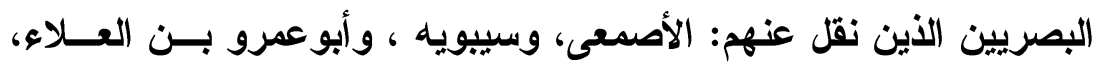

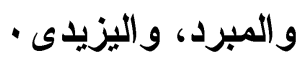

ومن العلماء الكوفيين: ابن الأنبارى، والفراء، والكســائى، وهشــام

$$
\text { الضرير }
$$

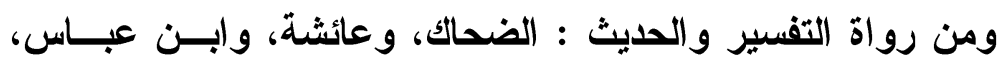

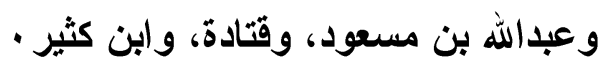

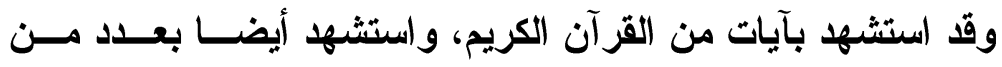

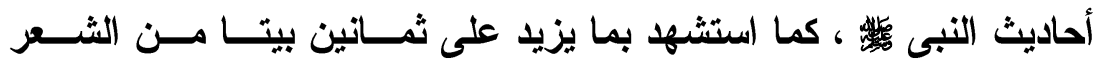

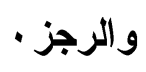

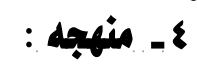

سأذكر منهج ابن خالويه فى كتابه الحجة بصفة عامة هنا وســوف

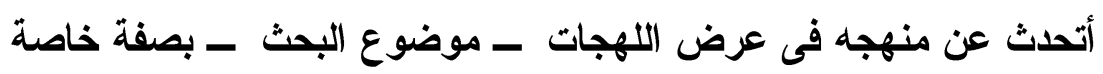

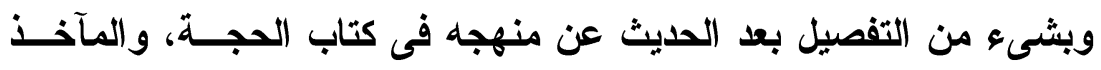

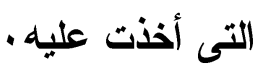

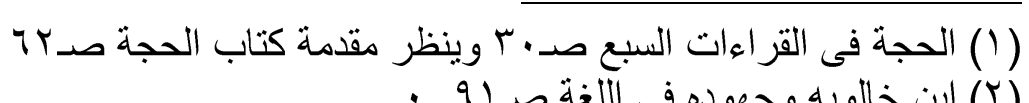

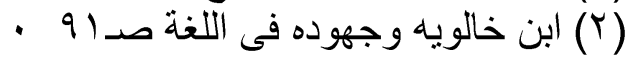


فلقد حدد الدكتور عبدالعال سالم مكرم منهج ابن خالويه فى الحجــة

بالنقاط التالية: (1):

1 - اعتمد فى حجته على القراعات المشهورة ، تاركا الروايات الثاذة .

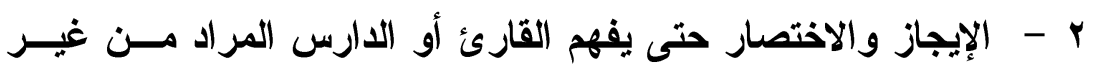

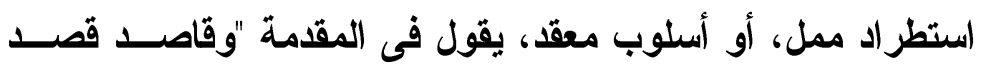

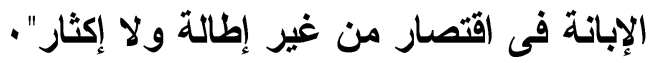

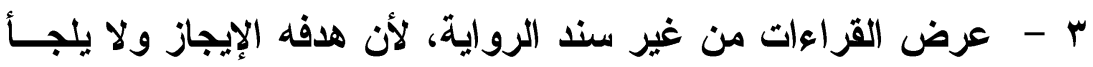

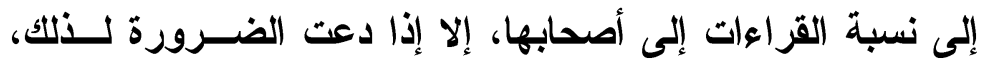

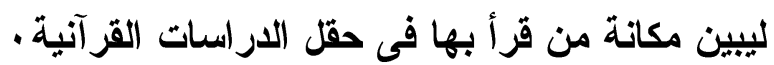

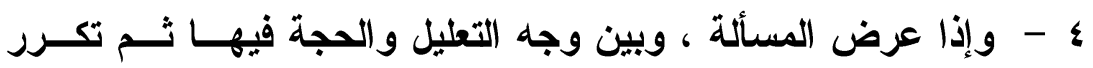

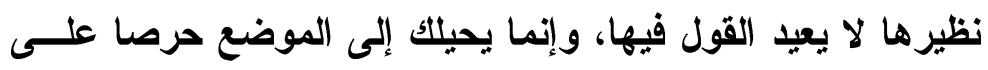

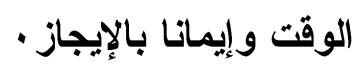

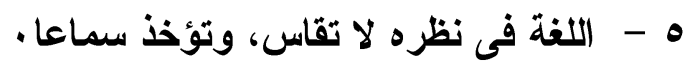

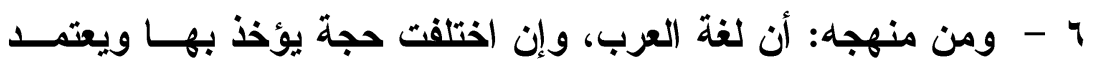

$$
\text { عليها. }
$$

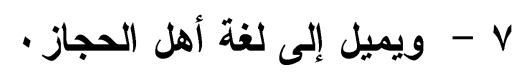

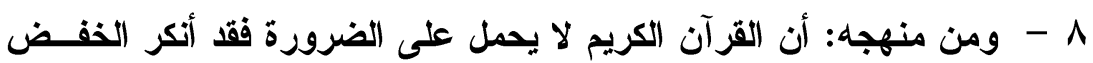

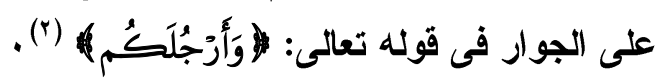

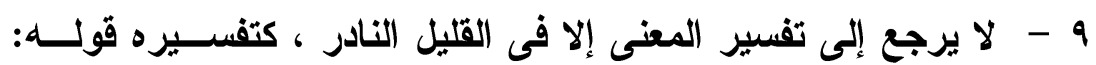

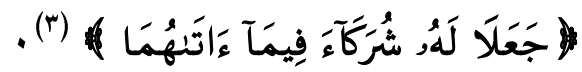

• 1 - من النادر تعرضه لإعراب الثواهد التى يحتج بها، ولكنه فى بيت:

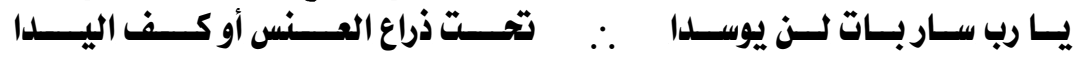
فإنه يتعرض لإعراب مواضع من البيث، مفسرا بعض كلماته(؛) .

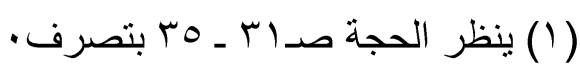

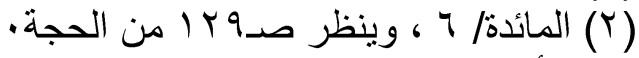

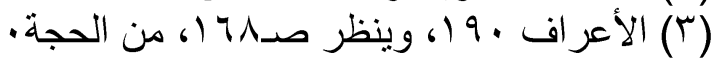

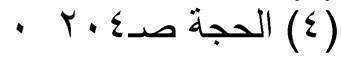


11

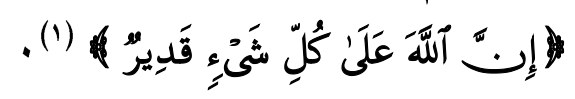

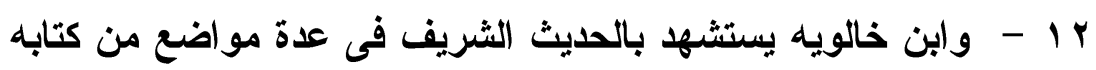

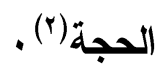

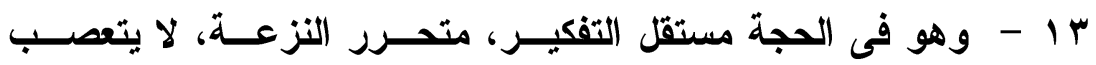

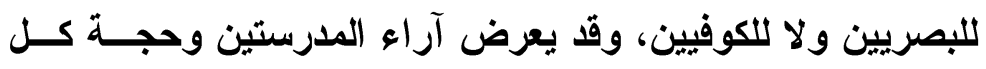

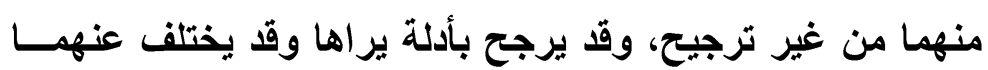

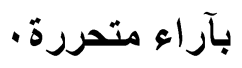

\section{0}

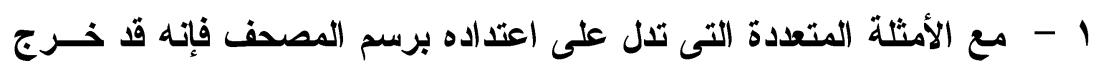

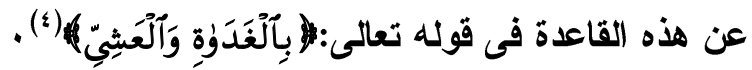

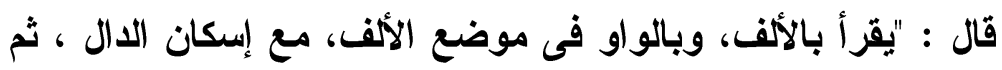

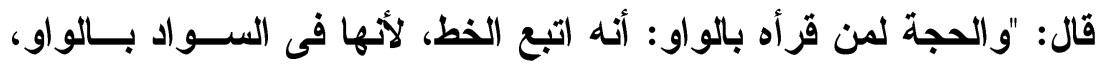

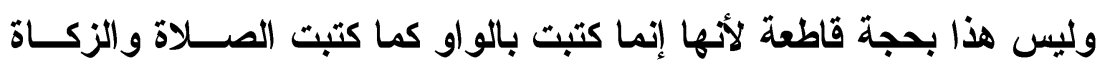

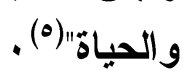

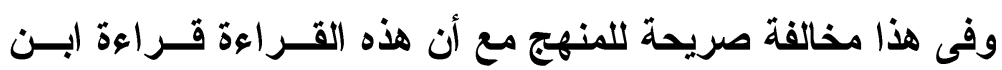

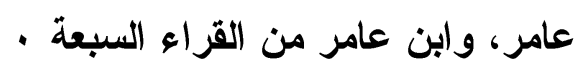

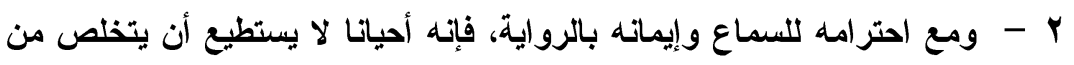

النزعة النحوية التى تؤمن بالعلة وتقدس المنطق(") .

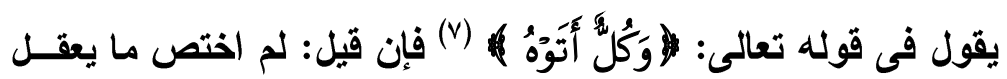

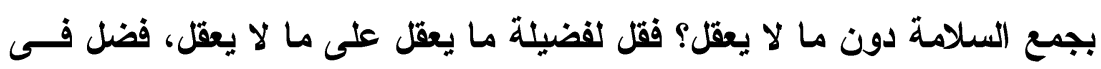

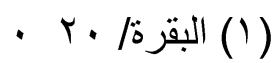

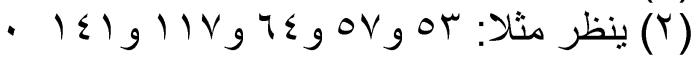

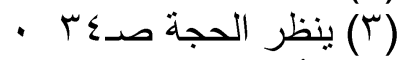

$$
\begin{aligned}
& \text { - or (ع) الأنعام (1) }
\end{aligned}
$$

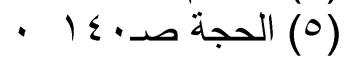

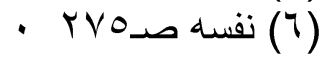

$$
\begin{aligned}
& \text { - NV/ النمل (Y) }
\end{aligned}
$$




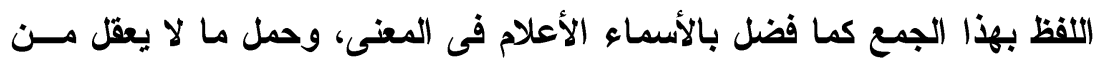

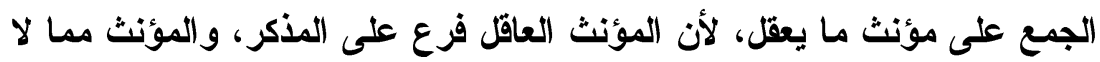

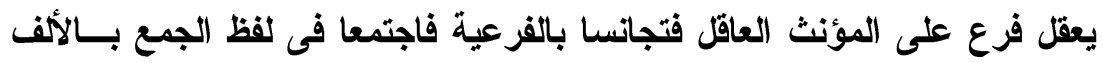

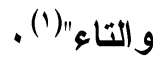

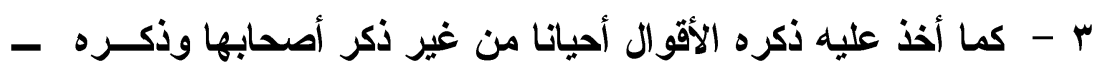

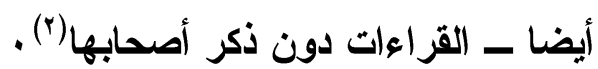

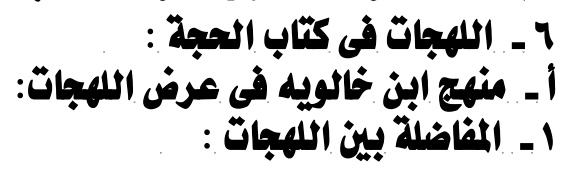

نرى ابن خالويه ــ أحيانا ـ يعرض اللهجة ثم يفضل لهجات علــى أخرى - مان

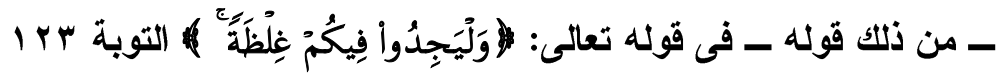

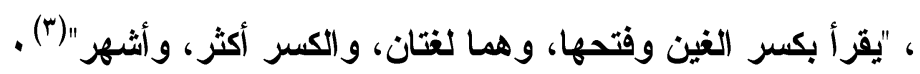

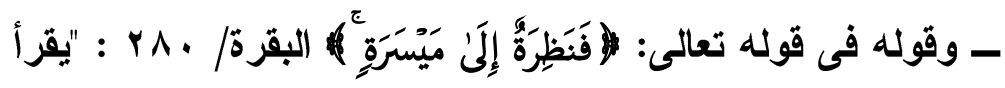

بضم السين وفتحها، وهما لغتان، والفتح أفصح وأثهر" (؛) .

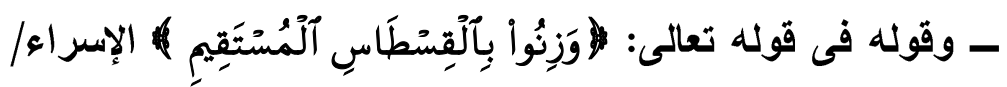

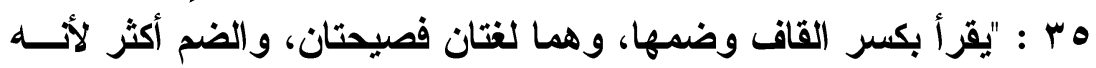

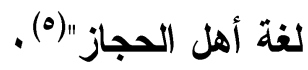

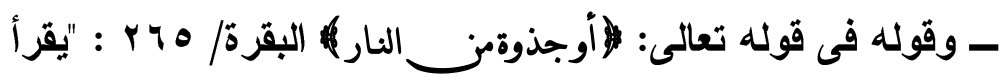

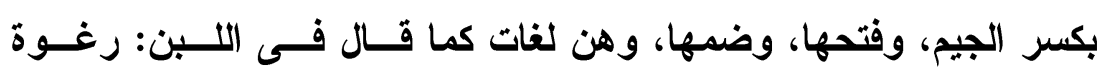

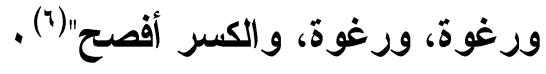

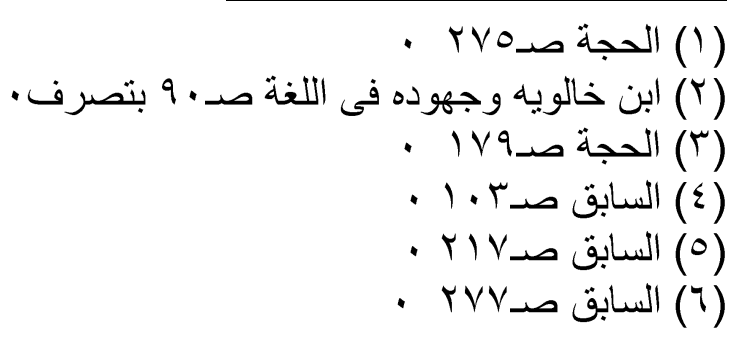




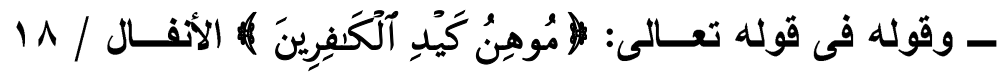

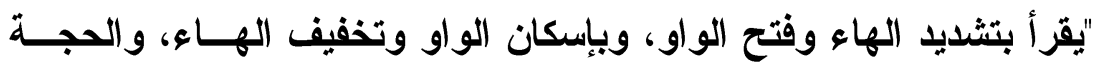

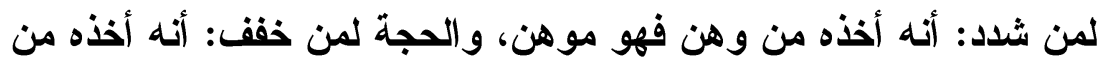

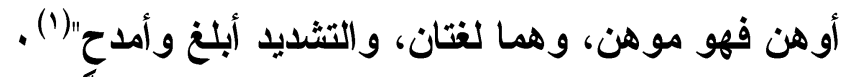

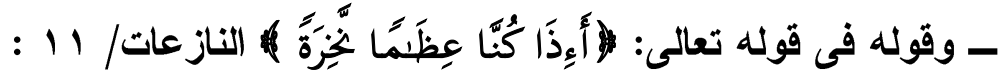

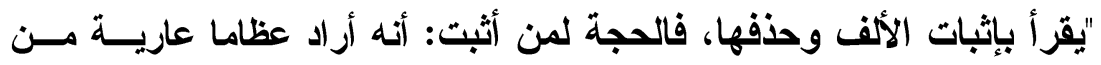

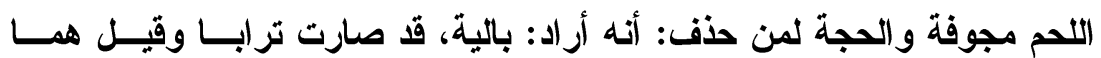

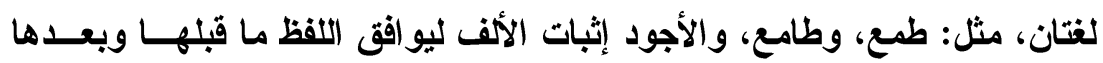

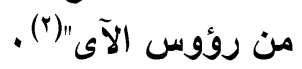

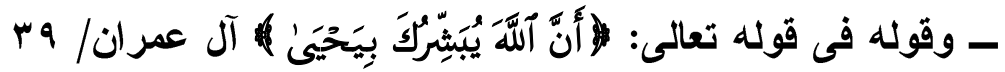

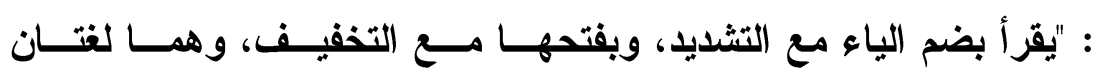

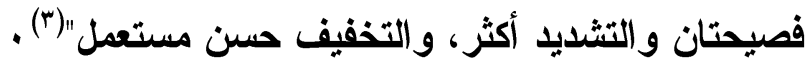

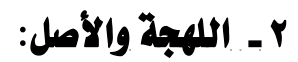

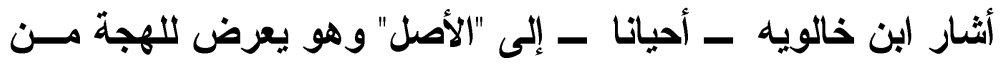

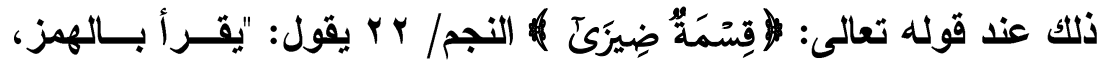
وتركه، وهما لغتان: ضأز، وضاز، ومعناهما: جار والأصل: ضم الضــاد،

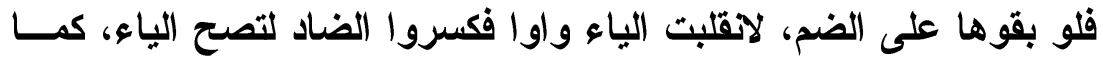

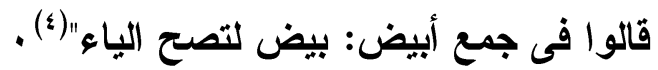

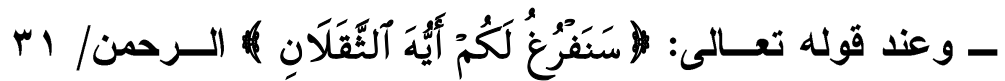
يقول: "يقرأ بالنون مفتوحة وضم الراء، وبالياء مضمومة وفتح الراء، وقد

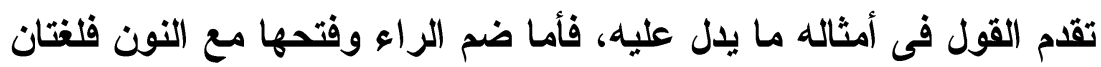

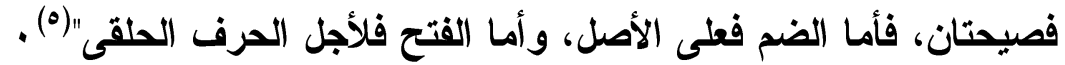

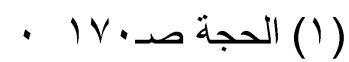

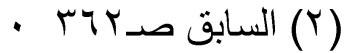

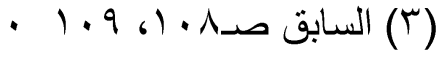

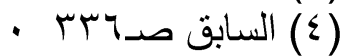

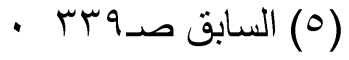




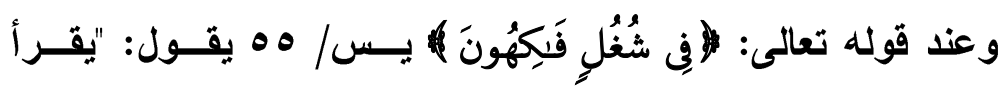
بضمتين متواليتين، ويضم الثين وإسكان الغين، فقيل هما لغتان فصيحتان وقيل الأصل: الضم، والإسكان تخفيف، ويضم (1) .

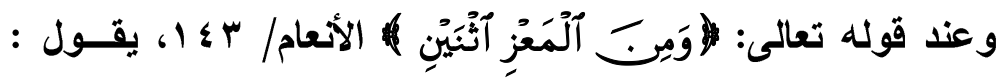

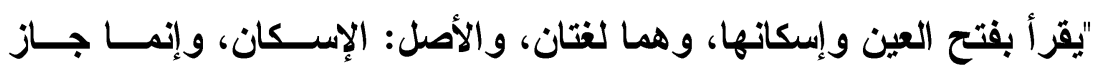

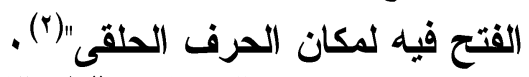

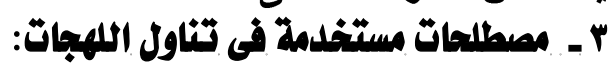
هناك بعض المصطلحات ذكرها ابن خالويه في تناول اللهجات مــن هذه المصطلحات:

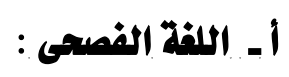

وقد استخدم ابن خالويه هذا المصطلح فى المواضع الآتية:

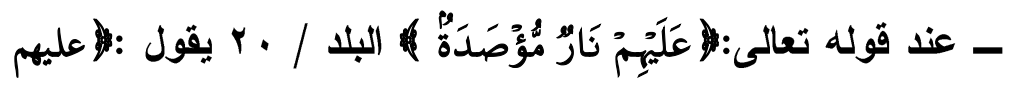
نارمؤصدة) هاهنا وفى "الهمزة"(ז) "آيقر آن بتحقيق الهمز وحذفه . فالحجة لمن حقى الهمز: أنه أخذه من آصدت النار فهى مؤصدة .

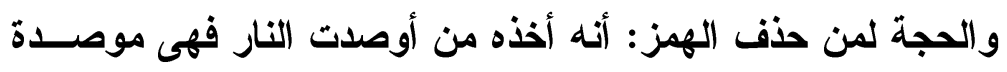

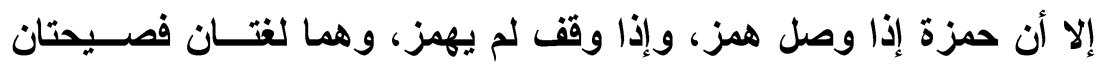
معناهما: أغلقت عليهم فهى مغلقة" (๕) .

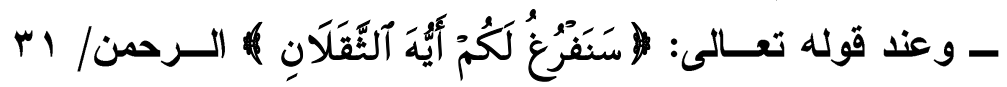
يقول: "يقرأ بالنون مفتوحة وضم الراء، وبالياء مضمومة وفتح الــراء ...

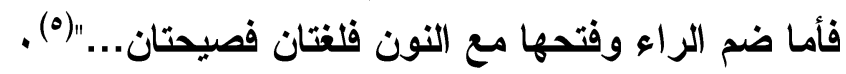

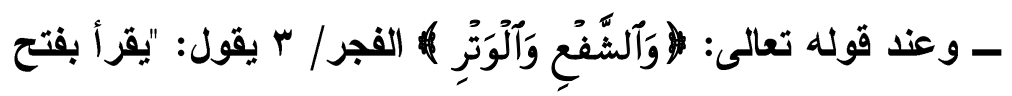
الواو وكسرها فالحجة لمن كسر أنه جعل الثفع: الزوج، وهما آدم وحواء

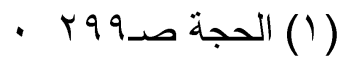

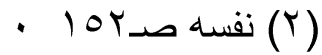

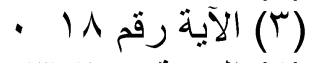

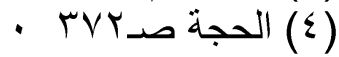

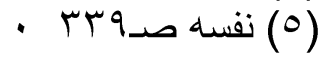




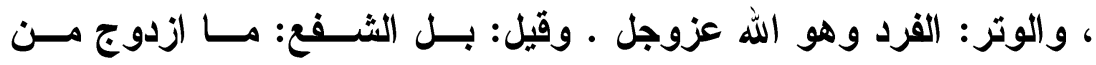

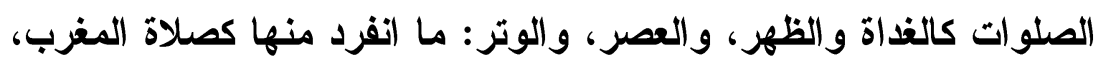

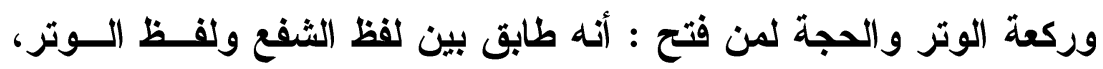

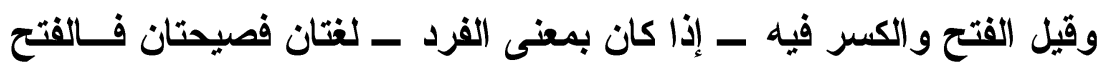

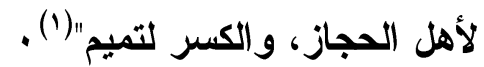

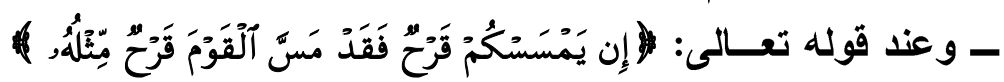

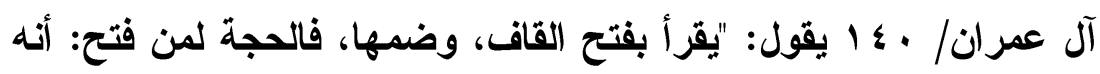

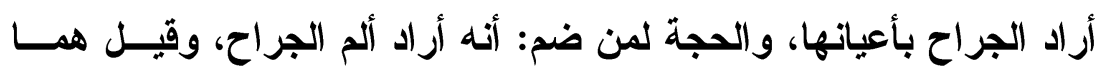

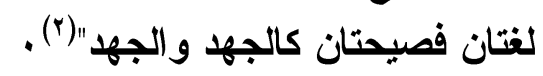

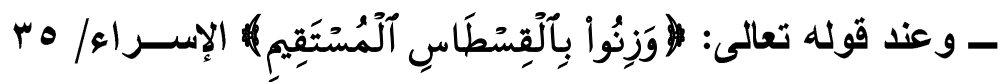
يقول: "يقرأ بكسر القاف وضمها، وهما لغتان فصيحتان"("َ) .

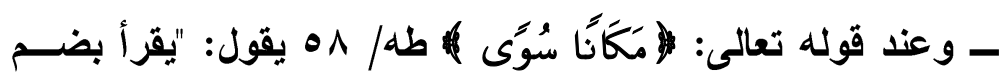

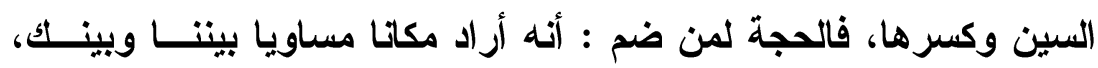

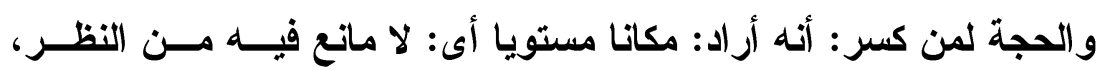

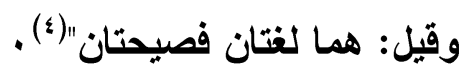

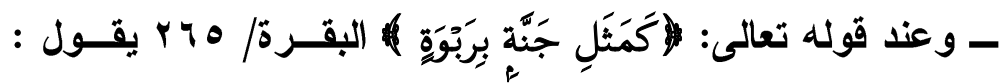
"قوله تعالى: (بوربوة) هاهنا وفى المؤمنين (ه) يقر آن بضم الـــراء وفتحهــا،

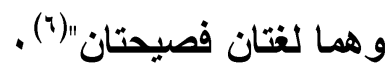

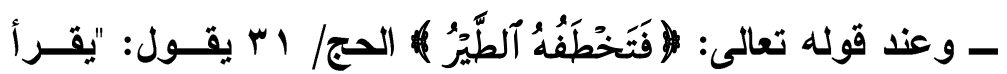
بفتح الخاء وتثديد الطاء ، وبإسكان الخاء وتخفيف الطاء ، فالحجة لمــن

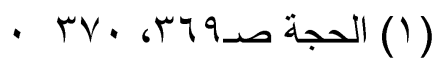

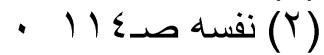

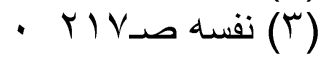

$$
\begin{aligned}
& \text { - } r \leqslant Y \text { ك }
\end{aligned}
$$

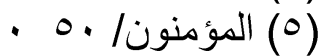

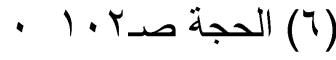


شدد أنه أراد: فتختطفه، فنقل فتحة التاء إلى الخاء وأدغم التاء فى الطـاء

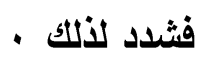

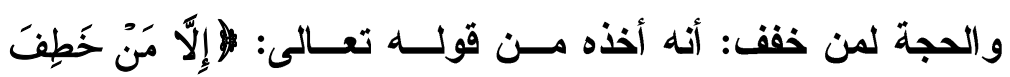

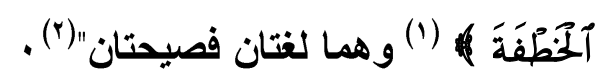

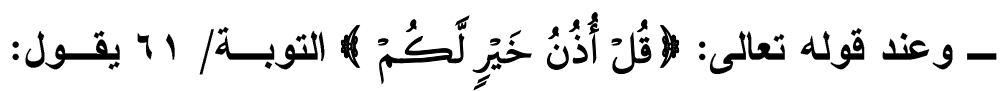

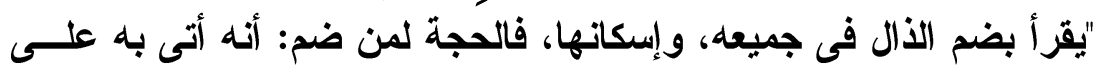

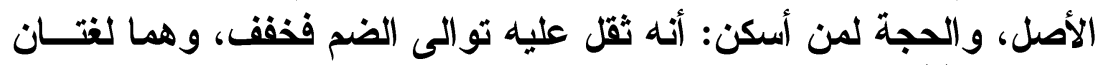

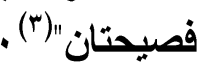

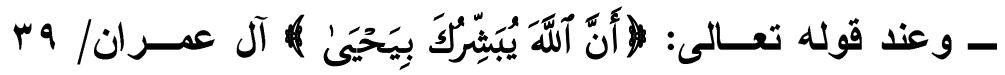

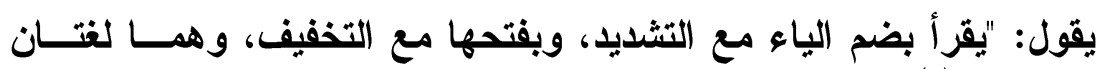

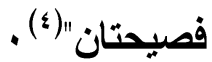

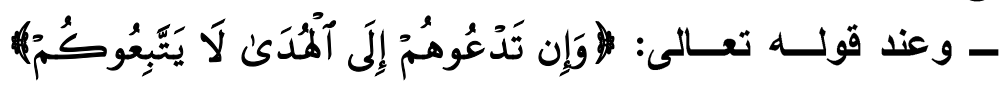

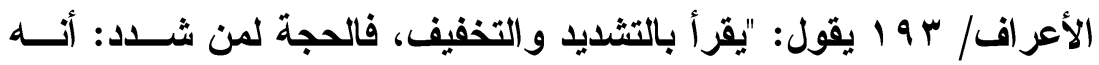

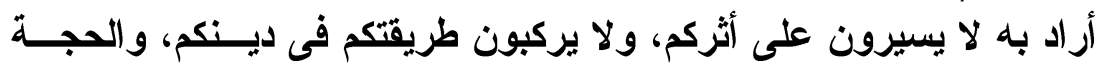

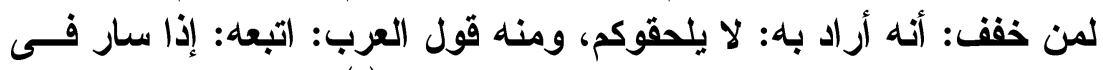

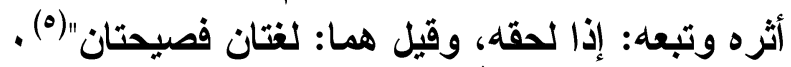

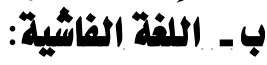

هى اللغة الكثيرة الاستعمال وقد استخدمها (بن خالويه فى الموضع الآتى :

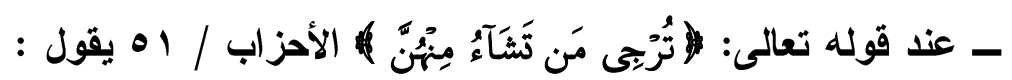

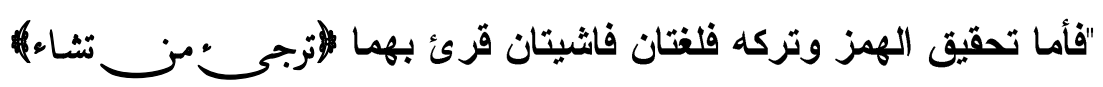

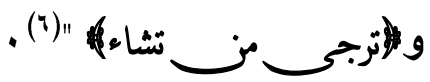

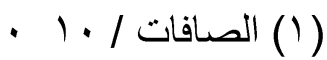

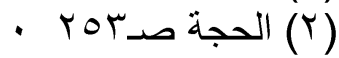

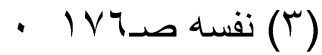

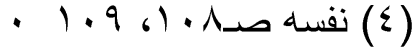

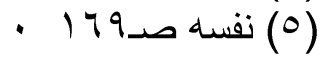

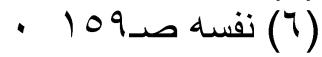




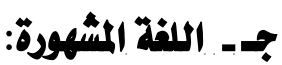

قد استخدم ابن خالويه هذا المصطلح فى الموضعين الآتيين:

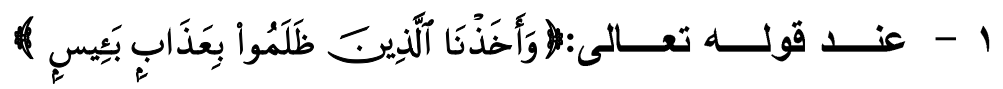
الأعراف/ 17 يقول: "يقرأ بئيس بالهمز على وزن "فعيل" و والبسر) بإثبات

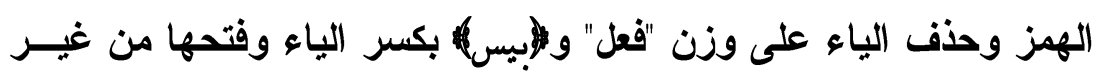

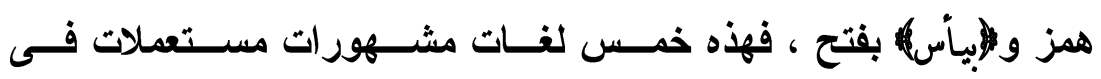

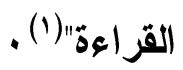

r - يقول : "... هذه لغة مشهورة للعرب يقولون فــى "رعاتــى" ،

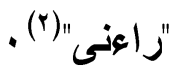

$$
\begin{aligned}
& \text { ك- ــ لهجات معزوة: }
\end{aligned}
$$

ونلاحظ على منهج ابن خالويه في تناول اللهجات أنه كان مقلا جدا

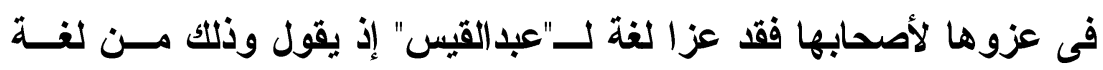

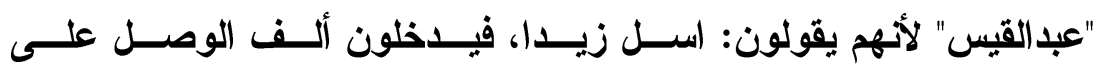

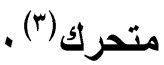

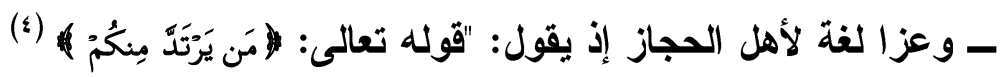

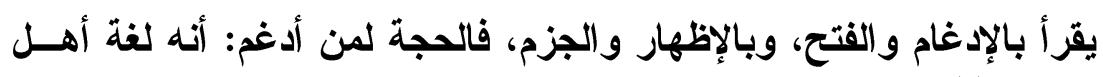

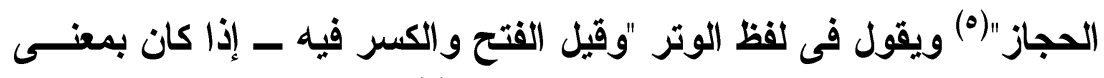

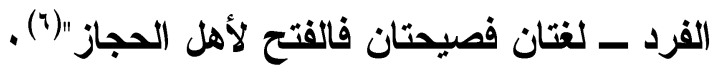

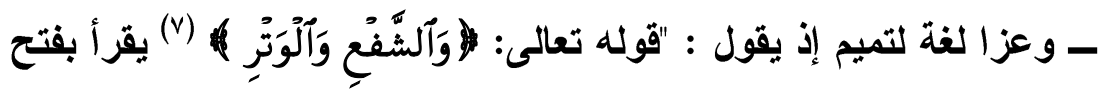

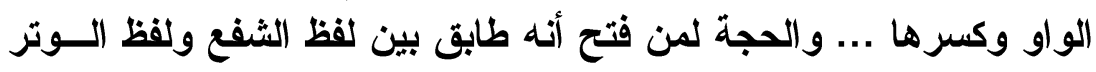

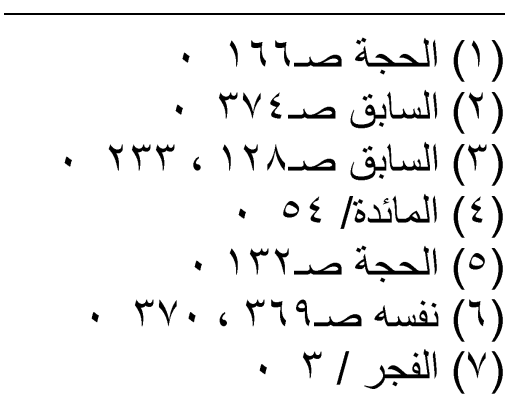


وقيل الفتح والكسر فيه ــ إذا كان بمعنى الفرد ـ لغتان فصيحتان فــالفتح

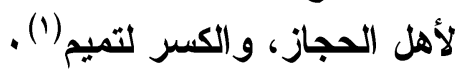

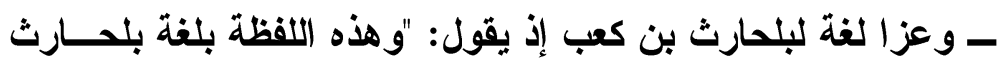

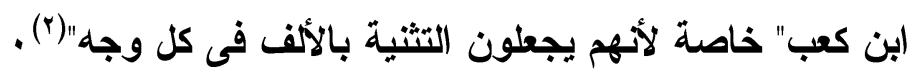

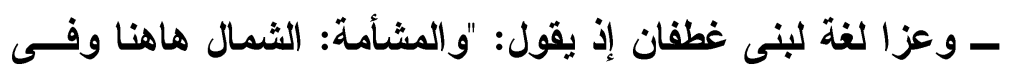

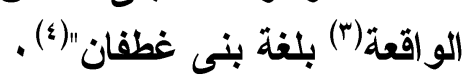

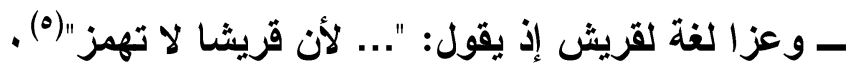

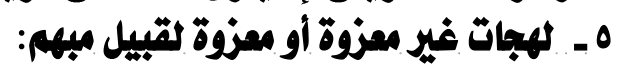

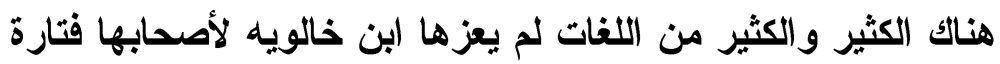

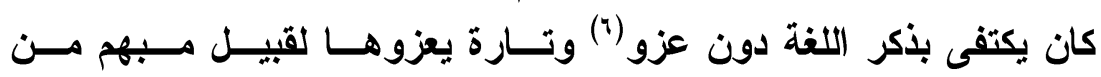

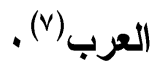

\section{7 ـ ت تفنيل السماع على الثقياس:}

اللغة فى نظر ابن خالويه لا تقاس، وتؤخذ سماعا إذ يقول في قوله

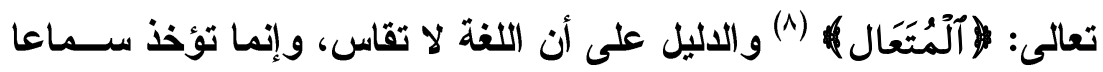
قولهز: الله متعال من : تعالى ولا يقال: متبارك من تبارك" (9) .

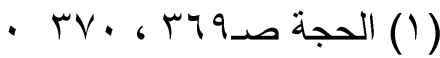

$$
\begin{aligned}
& \text { - نفسله صد r (Y) } \\
& \text { - } 9 \text { آية }
\end{aligned}
$$

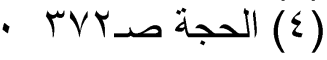

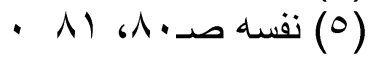

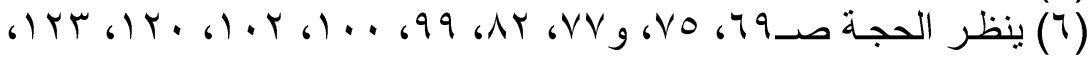

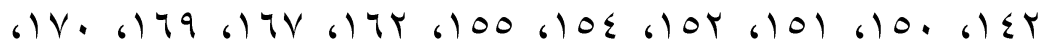
6YY. 6Y10 6 YIY 6197 61906 69. 6119 6 IVT 6IVE 6IVY

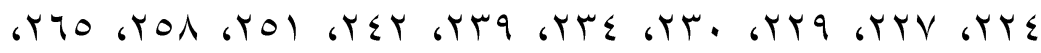
6 $Y$ I

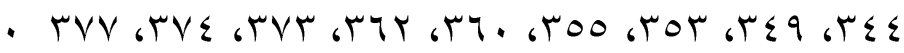

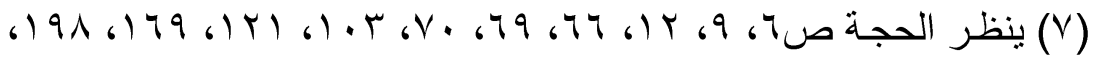

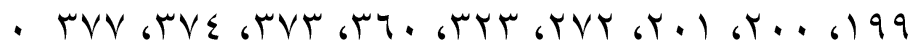

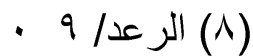

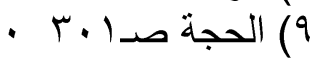




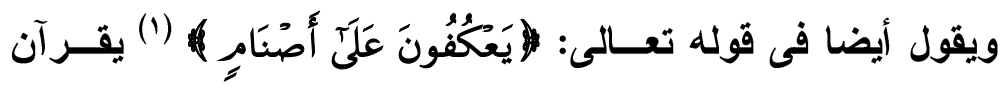

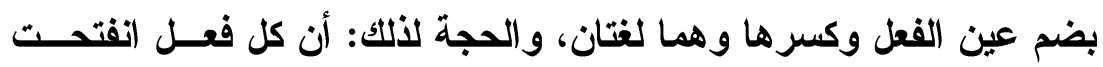

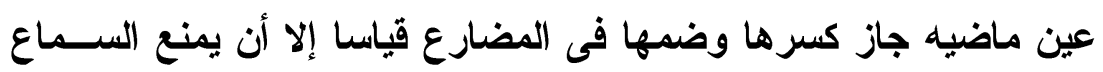

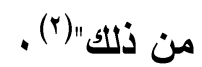

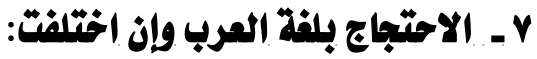

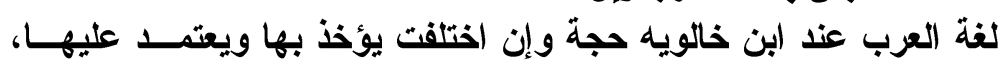

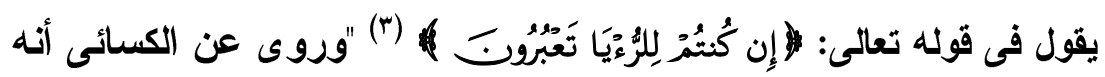

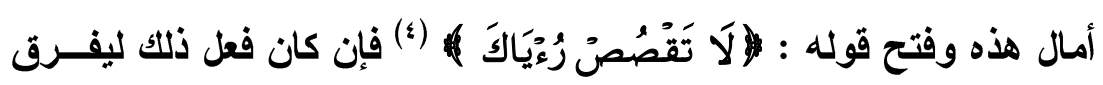

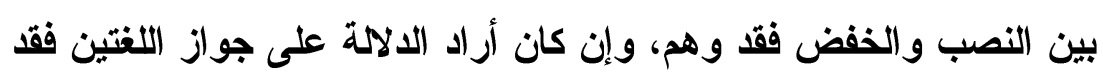
1 - اليل إلى لفة العجاز:

مال ابن خالويه إلى لغة أهل الحجاز والداليل على ذلتك قوله فى قوله

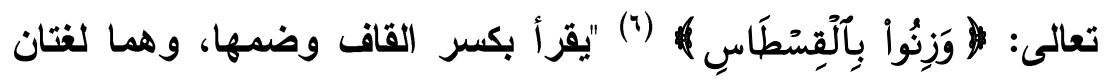

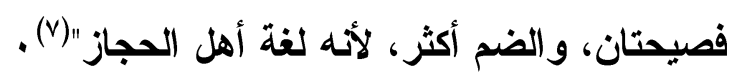

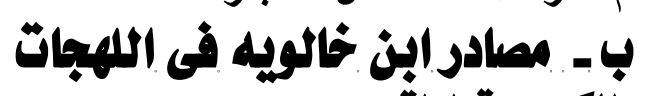

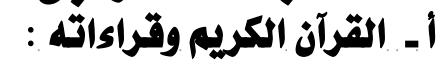

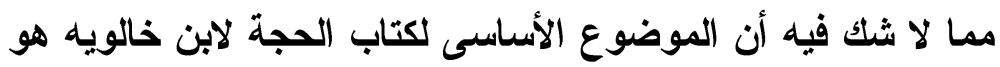

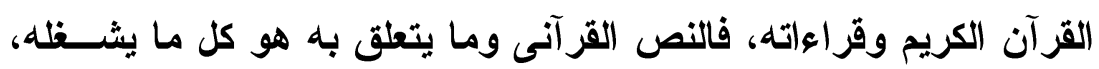

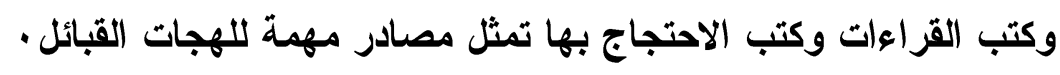

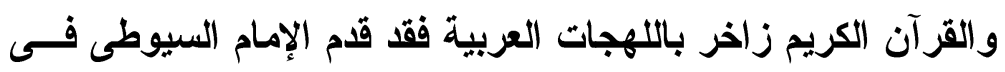

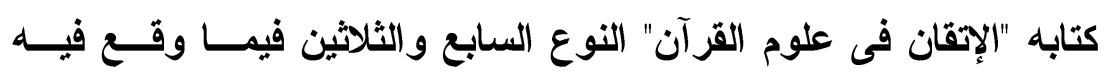

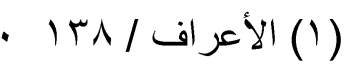

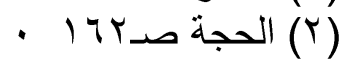

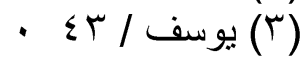

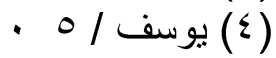

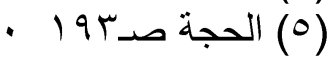

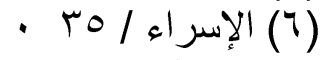

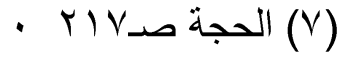




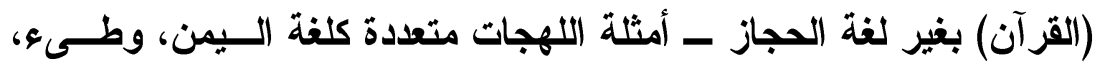

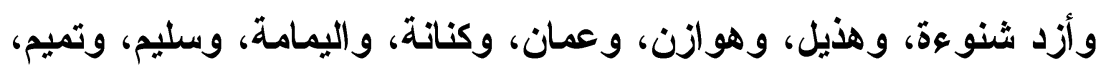

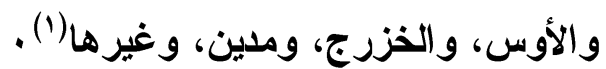

والقراعات مصدر أصيل من مصادر اللهجات العربية يقول أبوشامة:

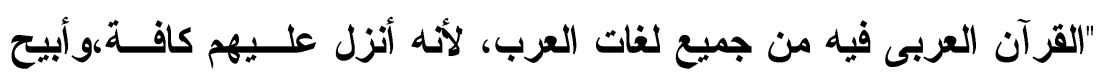

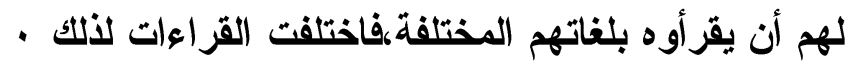

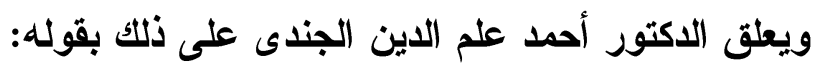

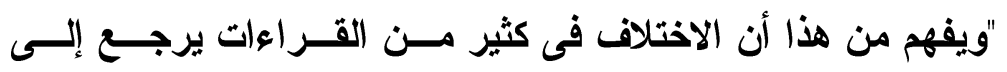

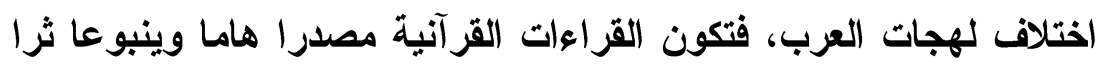

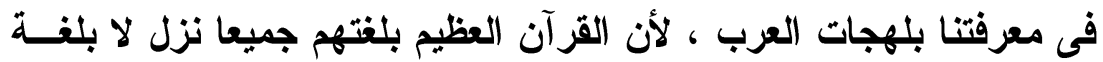

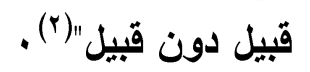

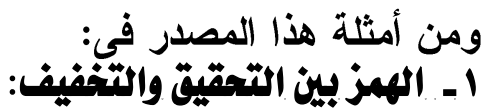

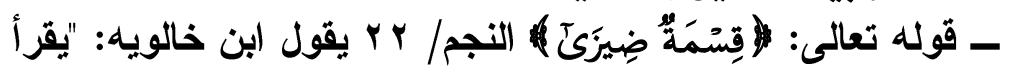
بالهمز وتركه، وهما لغتان"(") .

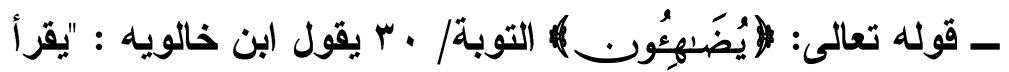

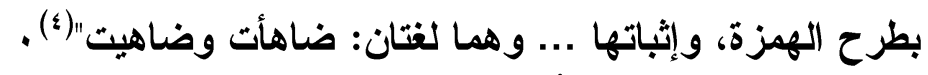

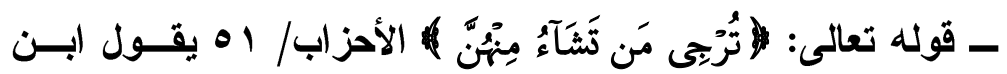

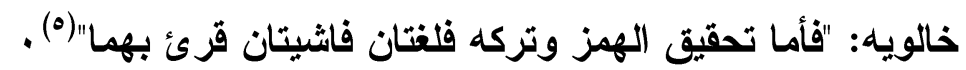

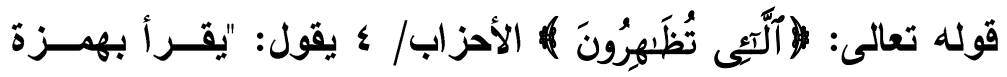

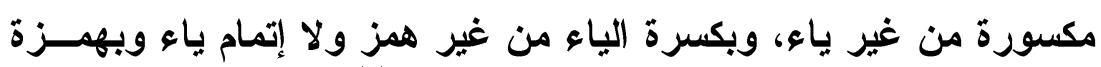

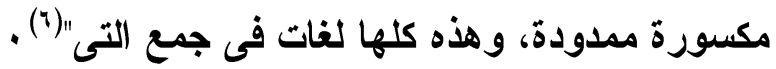

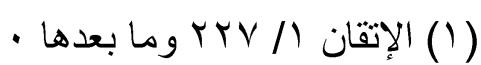

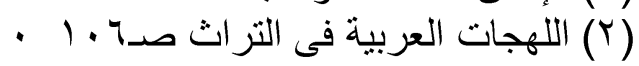

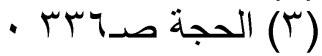

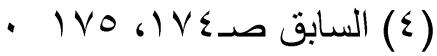

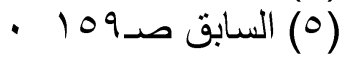

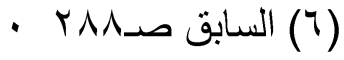




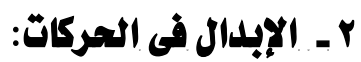

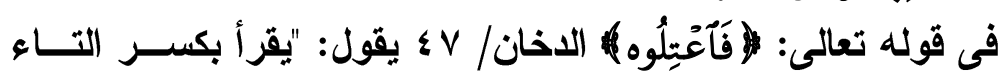

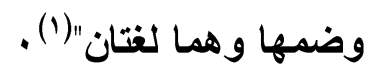

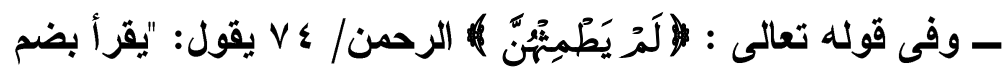

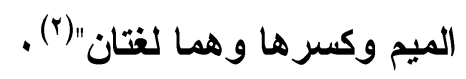

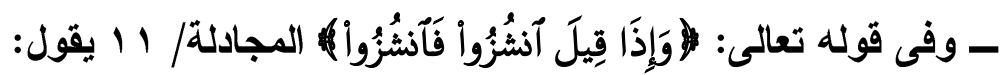

"يقرأ بضم الثنين وكسر ها، وهما لغتان" (() ).

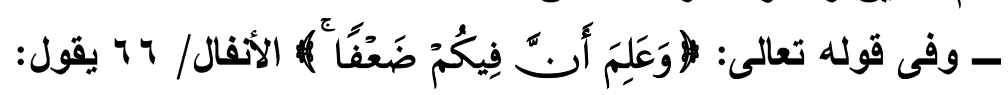

"يقرأ بضم الضاد، وفتحها، وهما لغتان"((4) ).

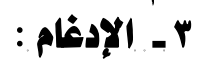

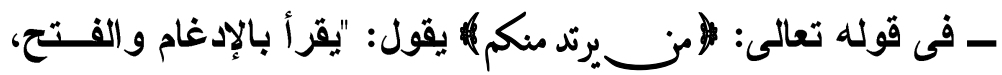

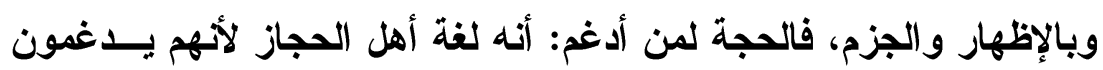

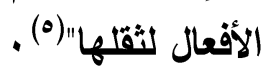

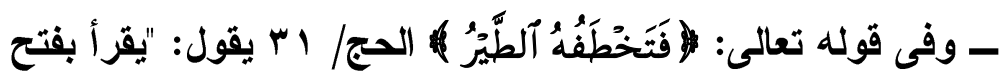

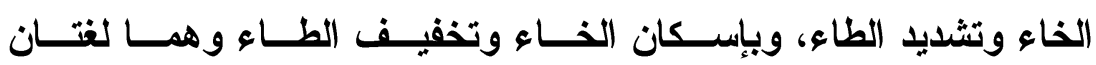

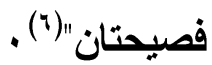
2- 2 - حلف العركة:

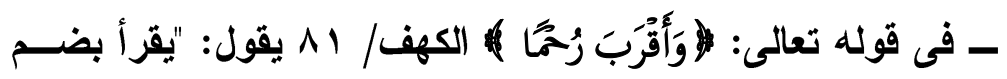

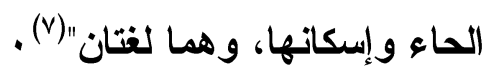

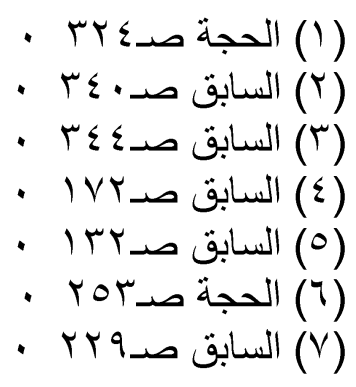




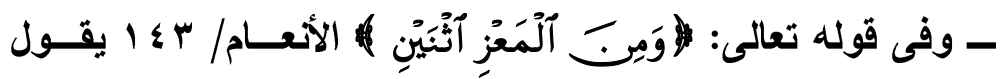

"يقرأ بفتح العين وإسكانها ، وهما لغتان" (1) .

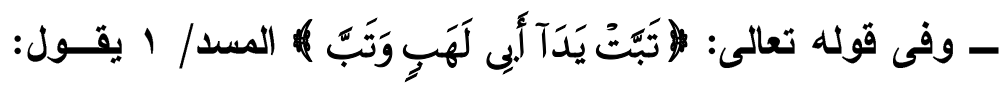

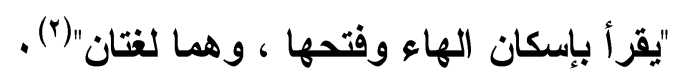

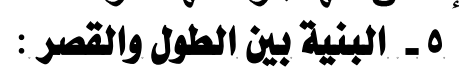

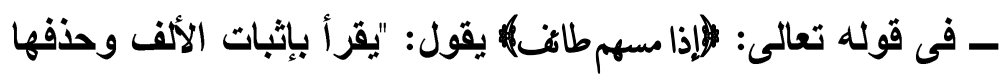
... و وهما لغتان طاف طوفا، وأطاف مطافا" (") .

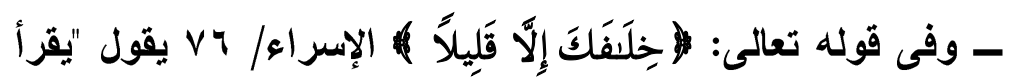

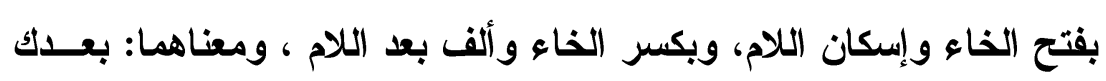

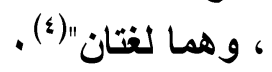

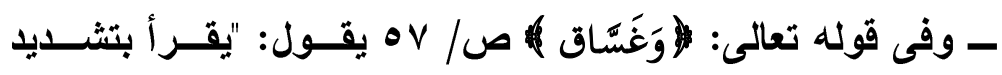
السين وتخفيفها ... و وهما لغتان" (ه) . .

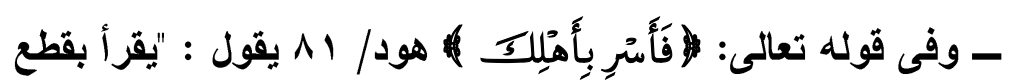

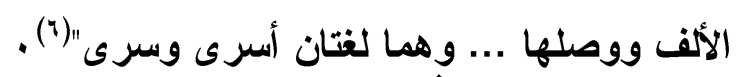

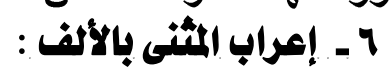

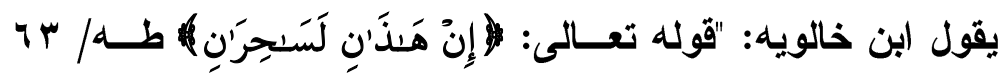

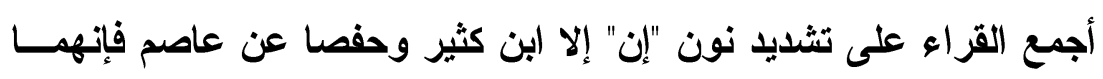

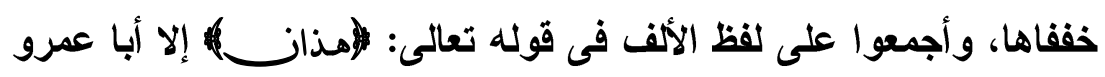

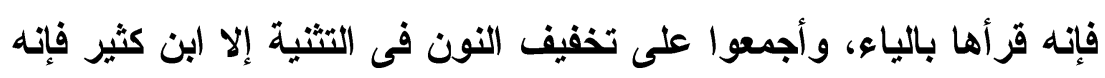

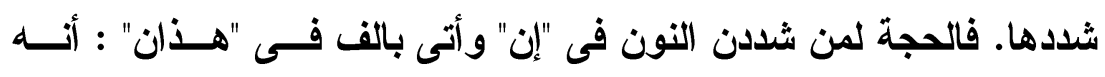

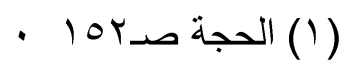

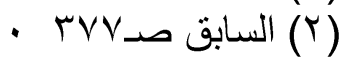

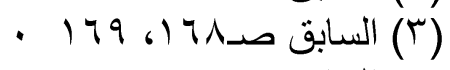

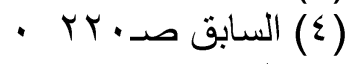

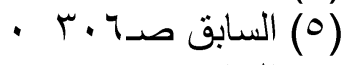

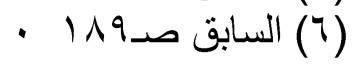


احتج بخبر الضحاك عن ابن عباس أن الله تعالى أنزل هذا القرآن بلغة كل

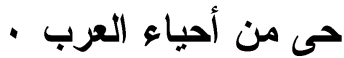

وهذه اللفظة بلغة "بلحارث بن كعب" خاصة بأنهم يجعـــون التثنـــة

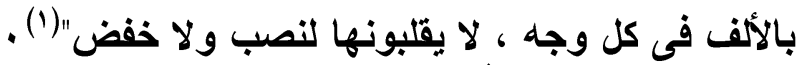

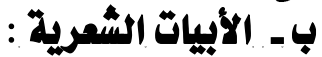

كان ابن خالويه ــ أحيانا ـ يستدل على الظواهر اللهجية بالأبيـات

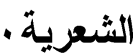
وفيما يلى ذكر لهذه الأبيات ومواضعها من الكتاب:

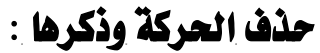

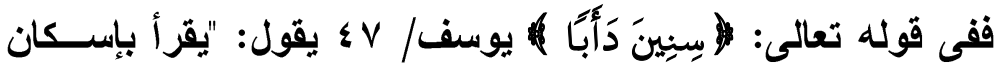

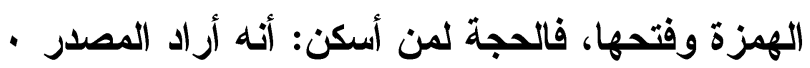

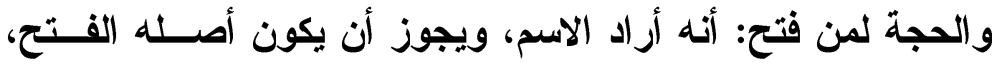

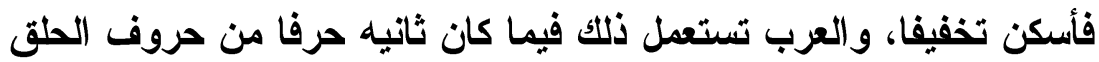

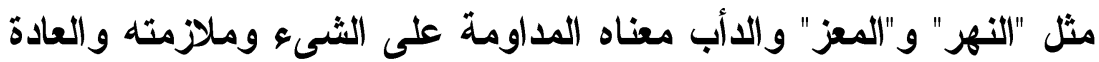

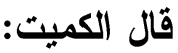

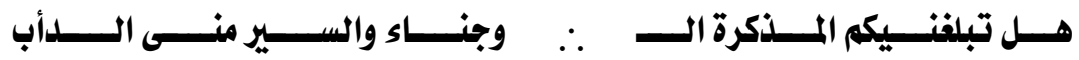

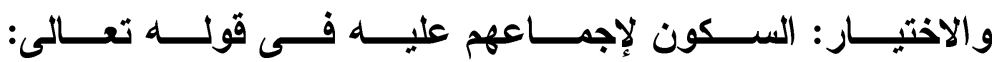

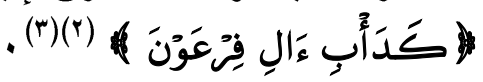

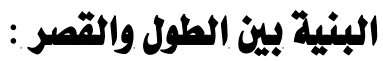

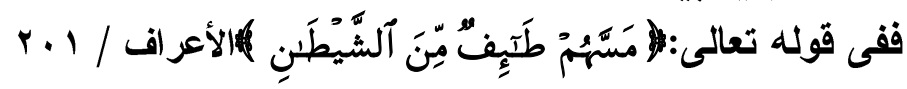

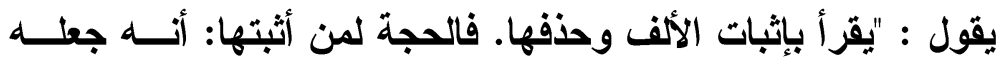

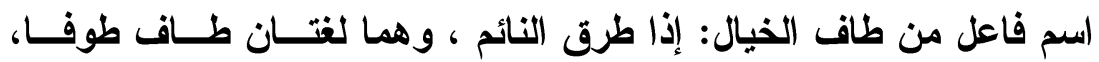

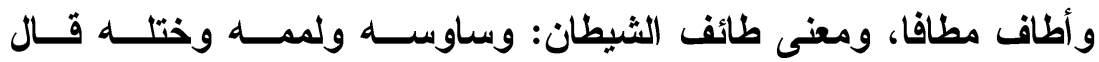

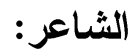

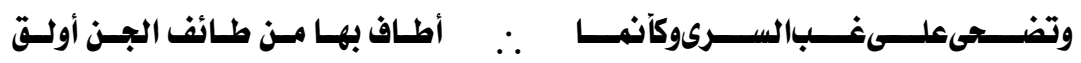




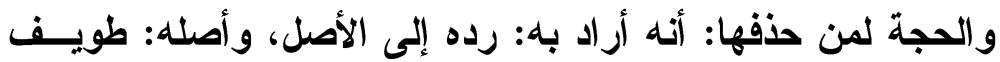

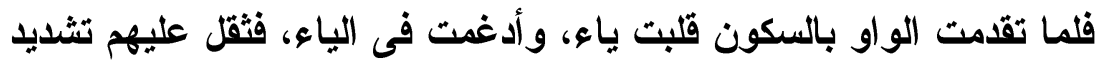

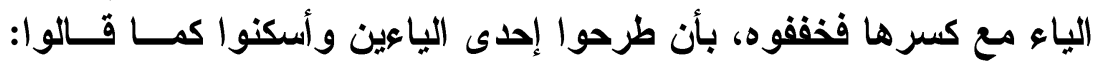

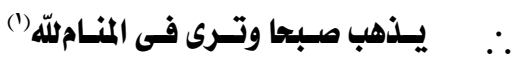
هين لين، قال حسان بن ثابت:

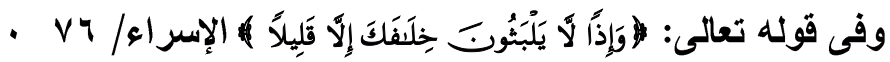

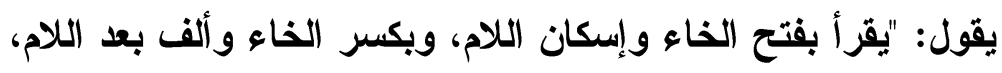

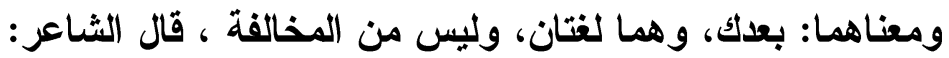

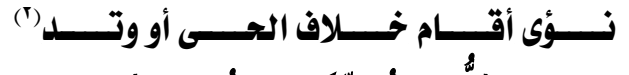

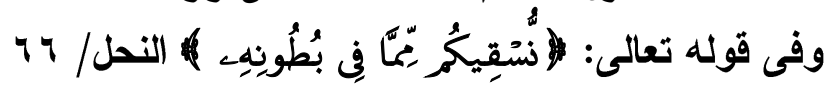

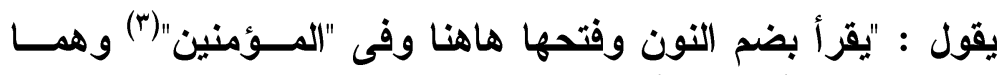

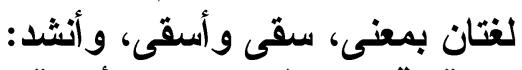

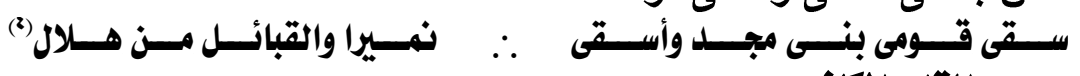

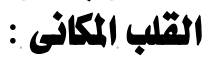

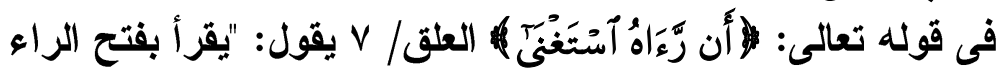

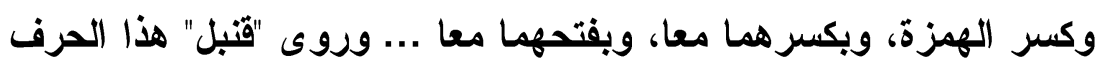

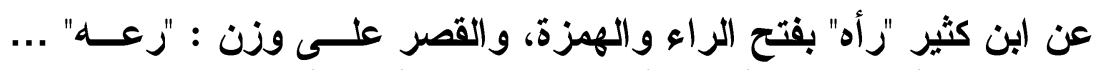

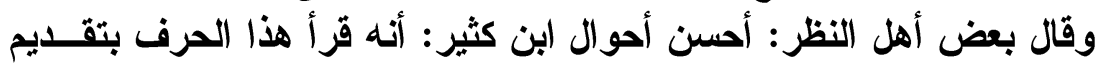

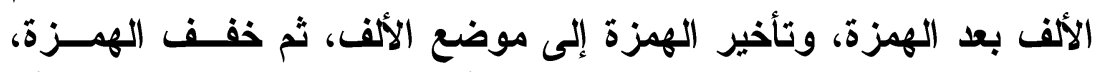

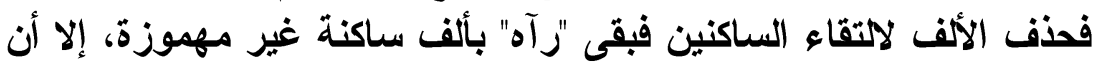

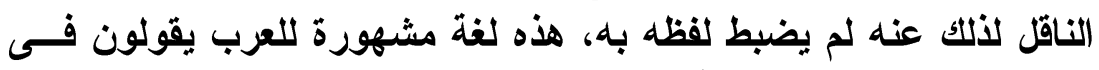

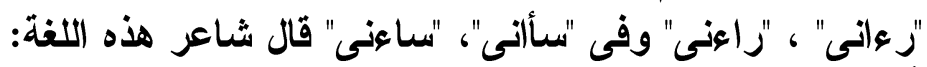

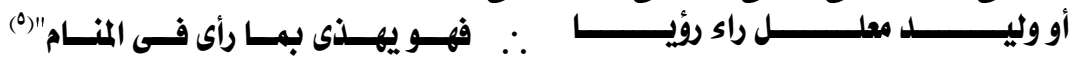

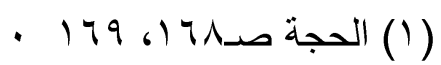

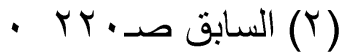

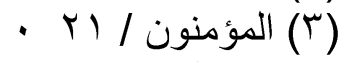

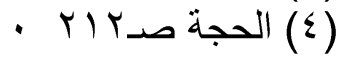

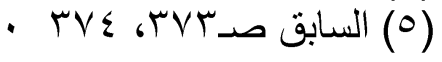




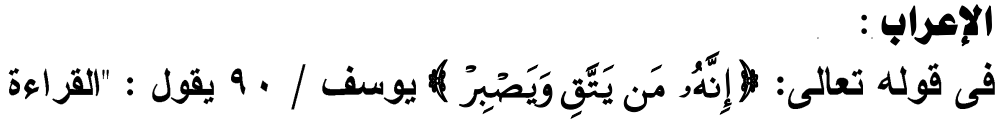

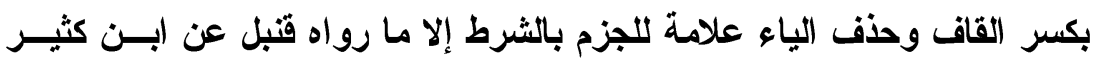
بإثبات الياء. وله في إثباتها وجهان:

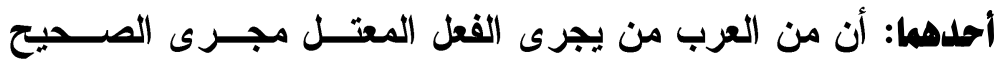

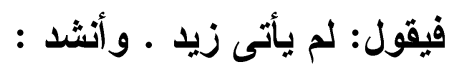

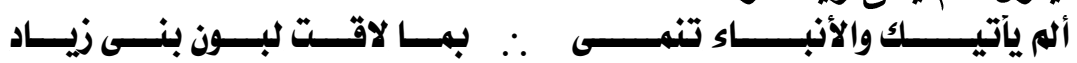

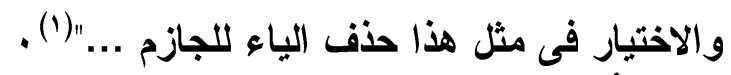

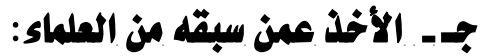
لقد نقل ابن خالويه عن كثير من العلماء كابن مجاهد وابن الأببارى

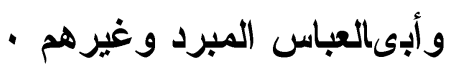




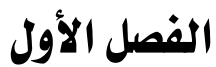 \\ الهمز بين التحقيق والتخفيف}

الهمزة حرف ثقيل فى النطق وذلك لإغلاق الوترين الصوتيين تماما

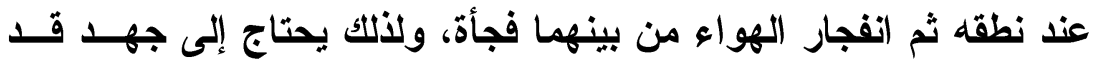

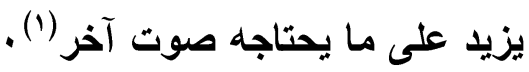
وقد اختلف الأقدمون والمحدثون فى مخرج الهمزة أهرة، فيرى الأقدمون

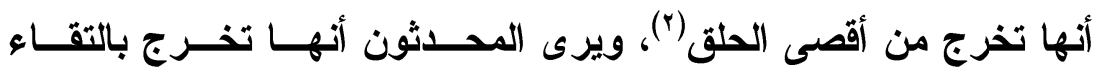

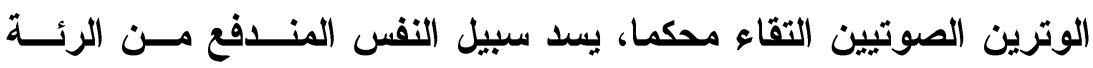

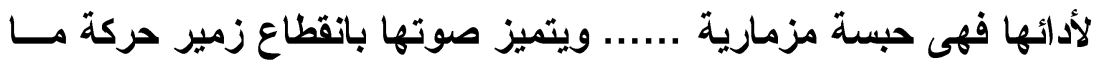

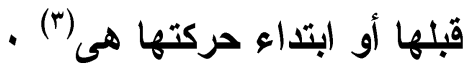

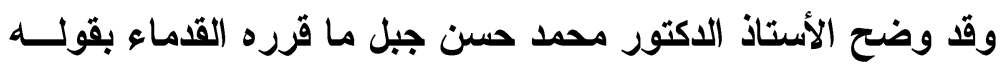

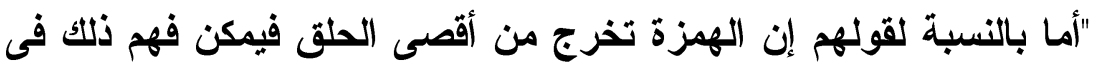

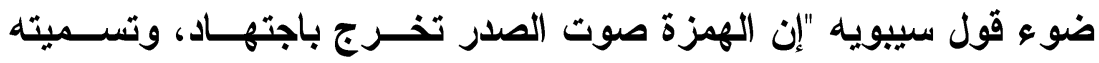

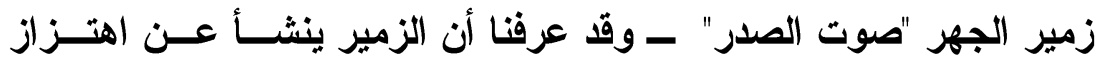

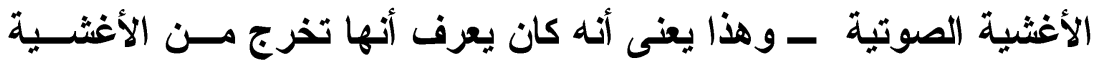

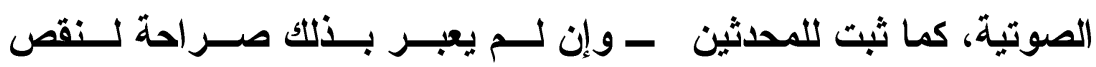

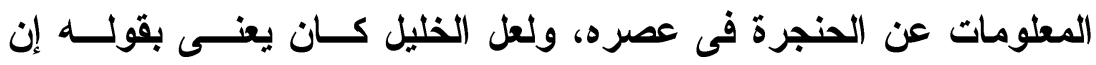

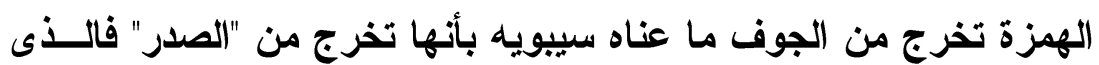

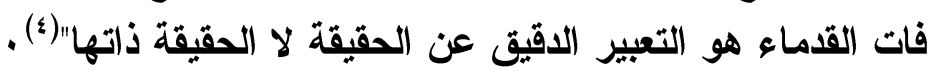

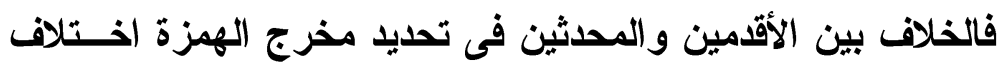

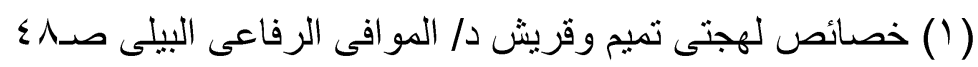

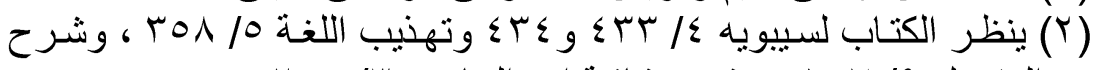

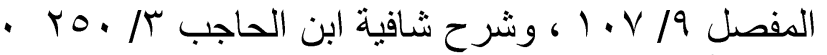

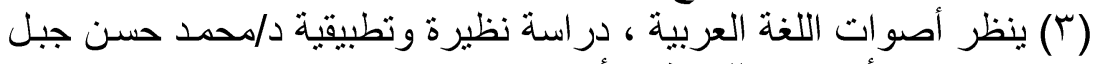

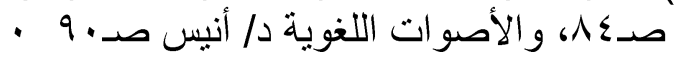

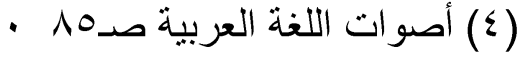




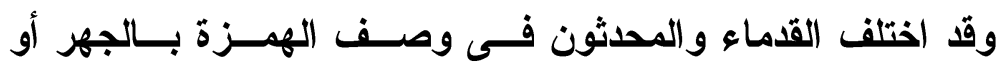

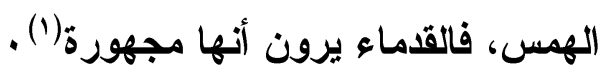

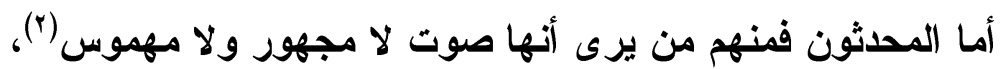

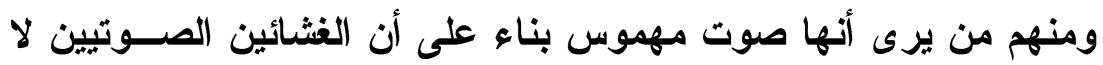

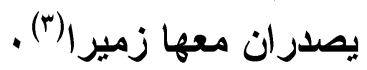

والقائلون بأنها صوت لا هو بالمجهور ولا بالمهوس بنوس بنوا مذهبهم على ما ذكره دانيال جونز من أن للحنجرة ثلاث وظائف: 1 - الانفتاح دون ذبذبة وذللك في المهموسات .

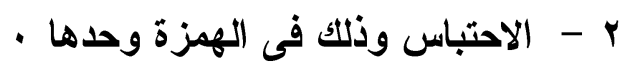

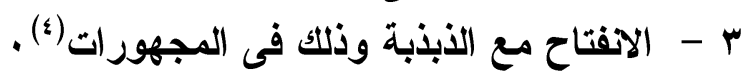

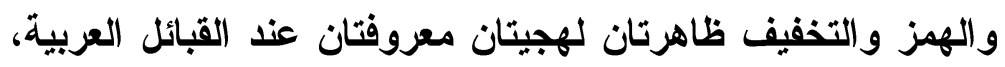

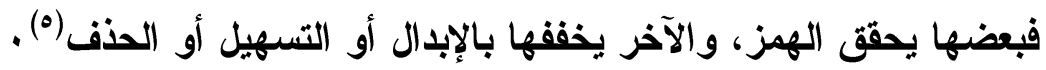

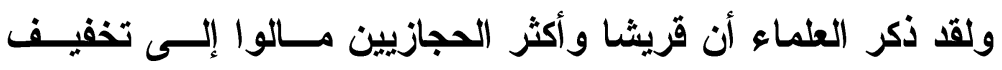

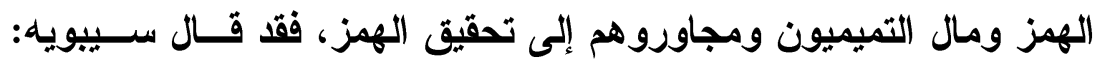

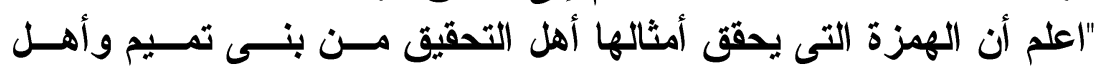

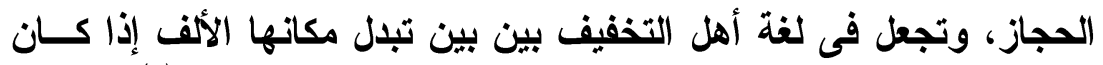

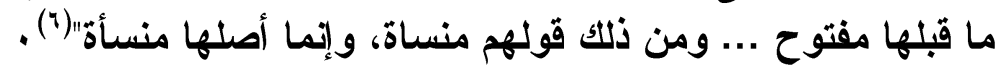

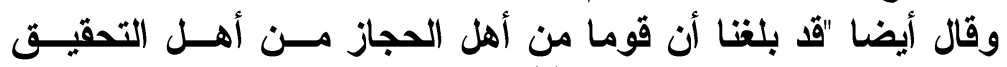

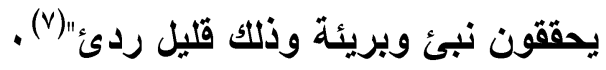

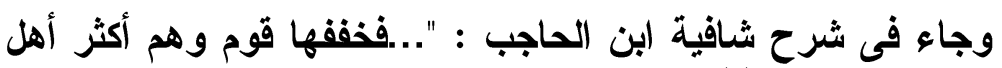

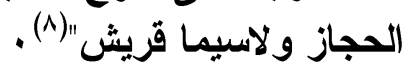

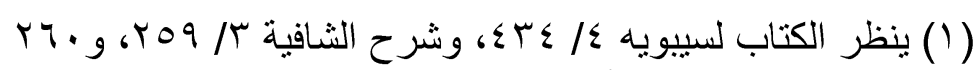

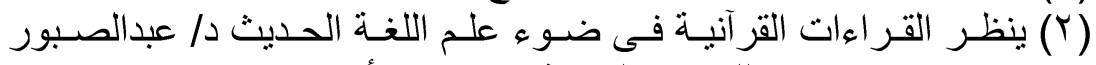

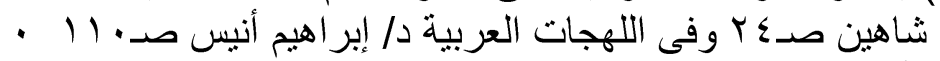

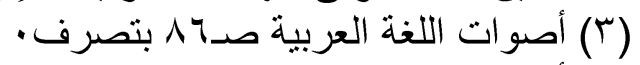

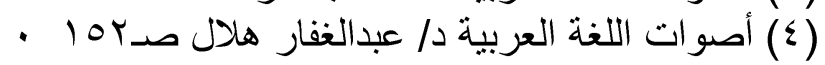

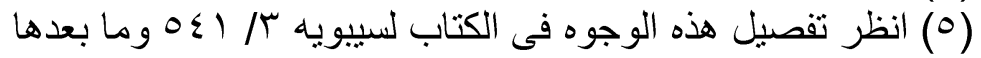

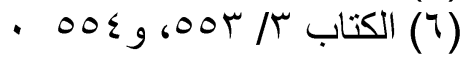

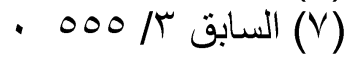

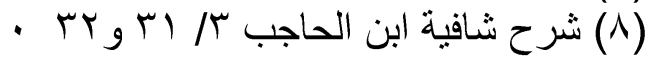


وذكر ابن يعيش أن النطق بالهمزة مستثقل ثم قال "... فــــلكك مـن

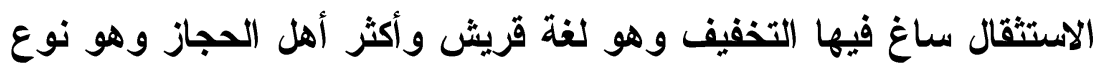

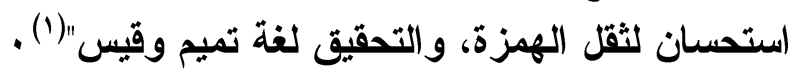

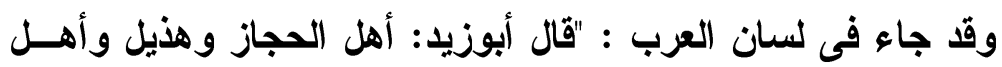

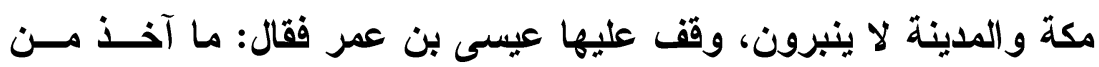

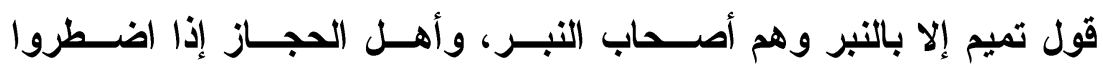

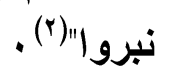

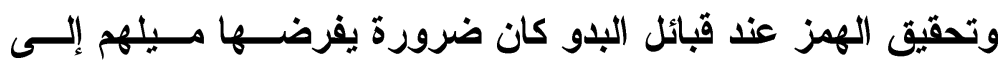

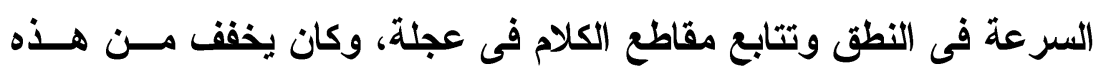

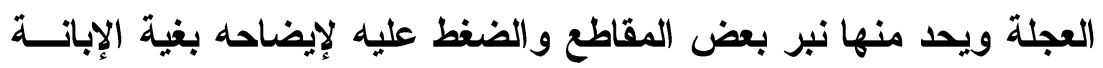

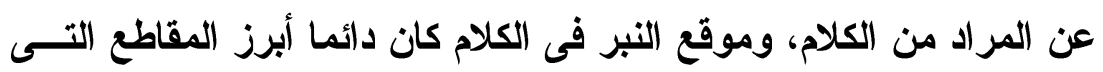
يوليها البدوى كل اهتمامه وضغطه (r) .

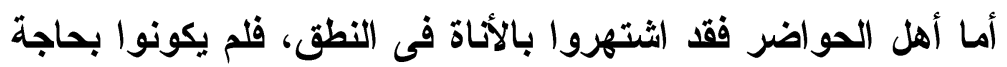

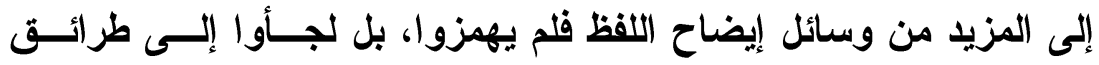
أخرى عبر عنها العلماء بتسهيل الهمزة أو تليينها أو تخفيفها أو إبــالها لهائا

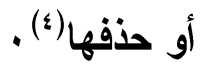

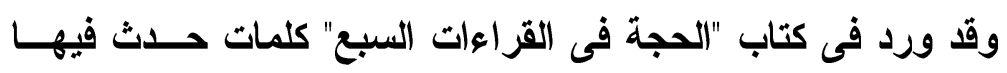

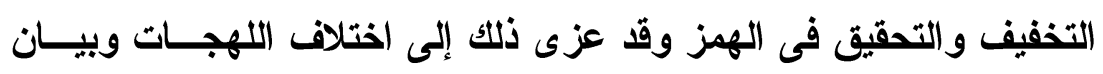
ذلك فيما يلى:

\section{أولا : الهمزة المفردة:}

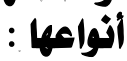

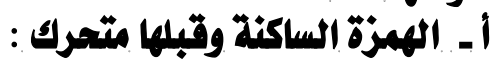

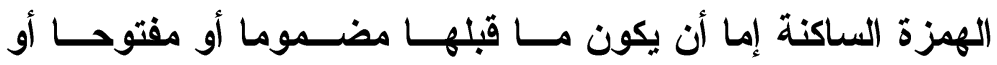

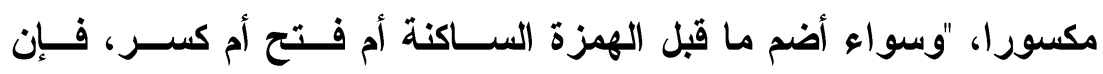

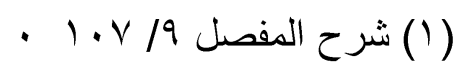

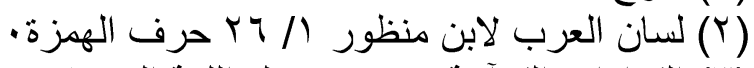

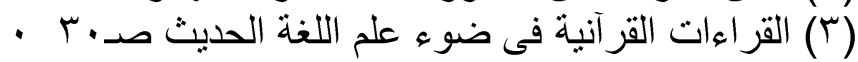

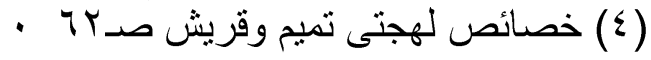


التخفيف القياسى لها يكون بإبدالها حرف مد من جنس الحركة قبلها، فإن

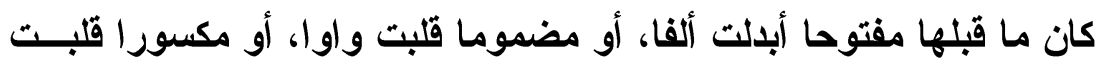

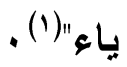

"وهو قياس مطرد فى كل ما كان بهذه الصفة ولا تجعلها هاهنا بين

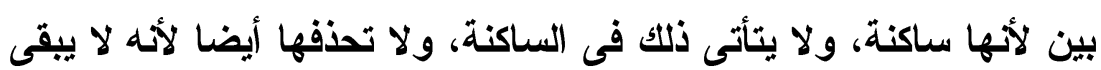

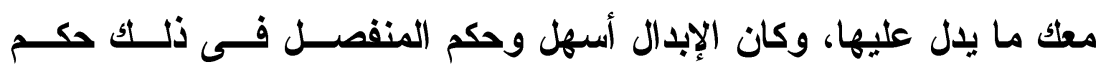

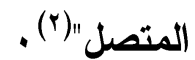

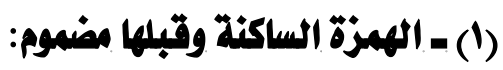

وردت الهمزة الساكنة وقبلها مضموم فى الموضع مونع الآتى :

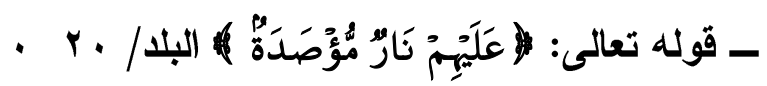

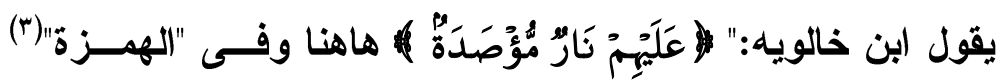

$$
\text { يقرآن بتحقيق الهمز وحذفه . }
$$

فالحجة لمن حقق الهمز: أنه أخذه من آصدت ألهن النار فهى مؤصدة.

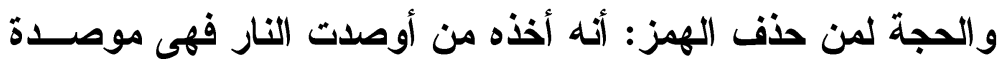

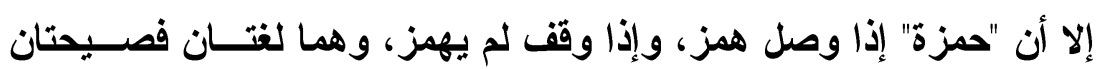

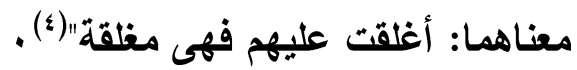
والأين قرأوا بالهمز لمؤصدة) هم: أبوعمرو، وحمزة، وحفص عـن

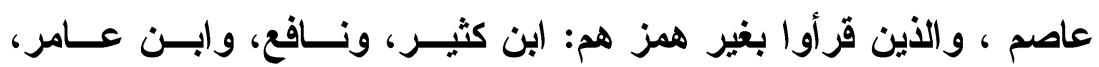

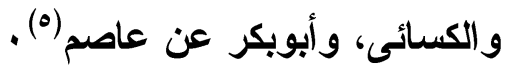

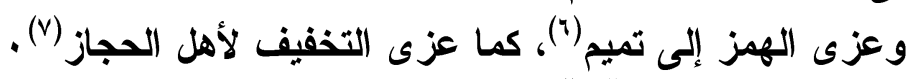
(") ـ ـ الهمزة الساكثة وقبهلها مكسور:

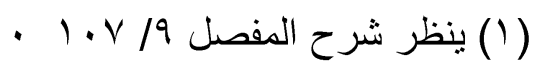

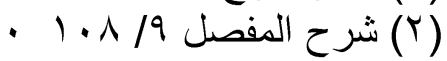

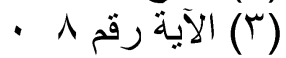

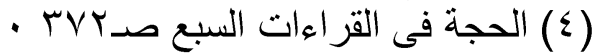

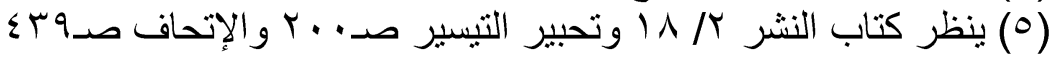

$$
\begin{aligned}
& \text { - rVV/r هز (T) } \\
& \text {. نفسه: نفس الصفحة (V) }
\end{aligned}
$$


وردت الهمزة الساكنة وقبلها مكسور فى الموضع الآتى:

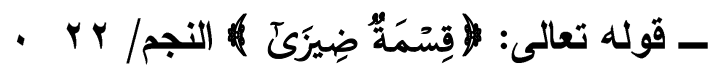

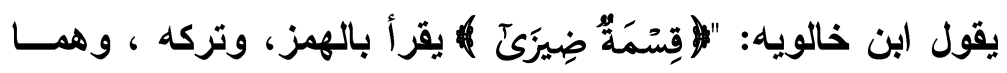

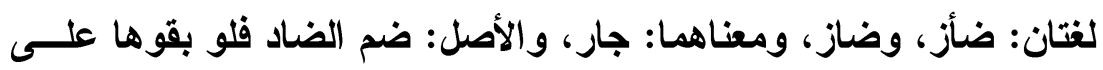

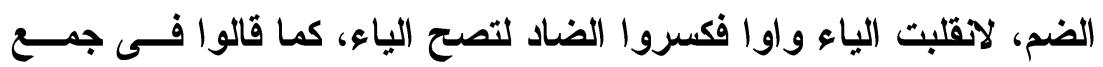

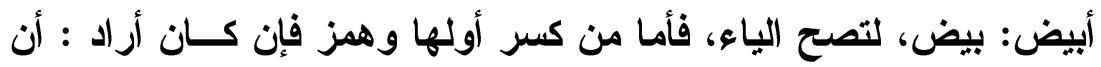

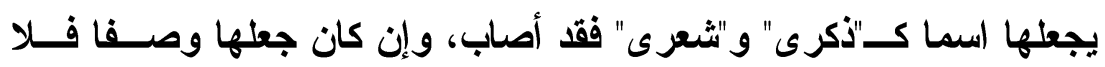

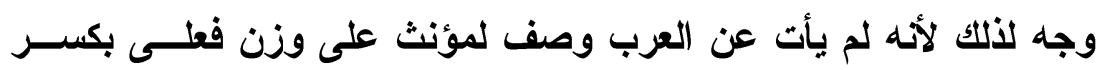
(الفاءع|(1) (1) (1)

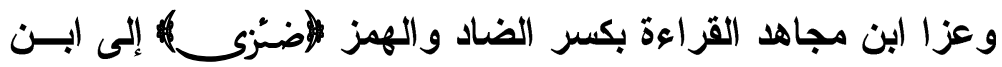
كثير (r) (ك)

كما عزا ابن مجاهد القراعة بكسر الضاد وبغير هــز إلـى بـــى القراءو

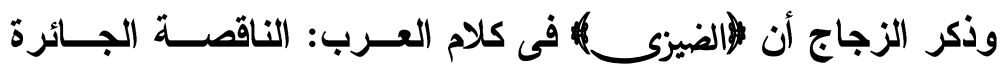

يقال: ضازه يضيزه، إذا نقصه حقه، ويقال: "ضأزه يضأزه" بالهمز (آ) .

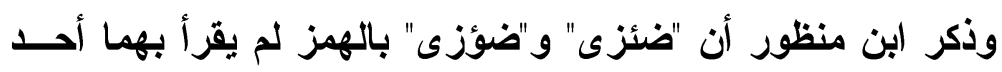

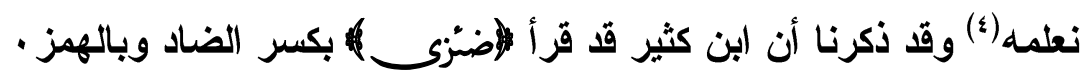

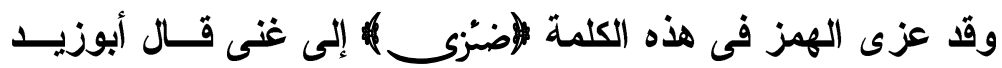
"سمعت رجلا من غنى يقول هذه قسمة ضئزى بالهمز (0) .

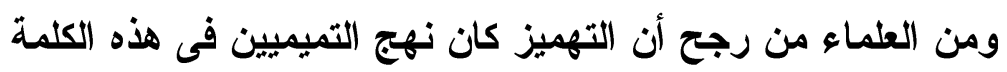

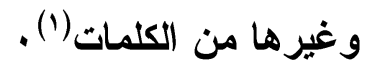

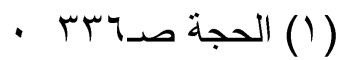

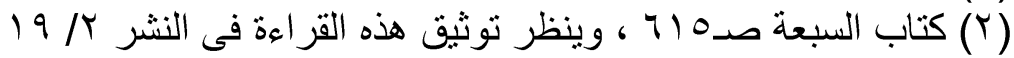

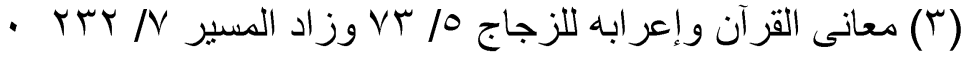

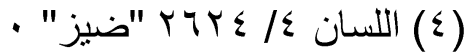

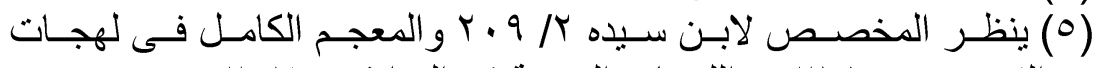

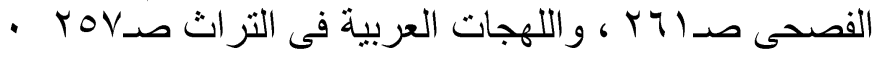




\section{بـ ـ الهمزة المتحركة وقبلها متحرك :}

التخفيف القياسى للهمزة المتحركة وقبلها متحرك يكون بجعلها بين

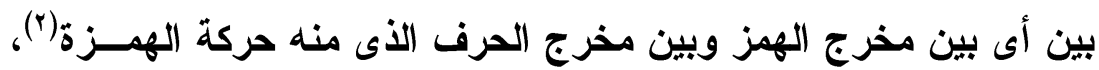

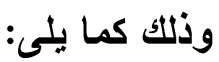

1 - إذا كاتت مفتوحة قبلها مفتوح جعلتها متوسطة فى إخراجهــا بـين

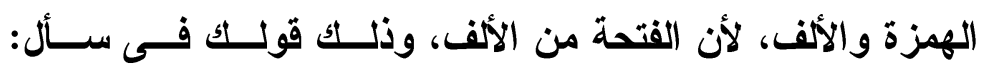

r - إن كانت مفتوحة قبلها ضمة أو كسرة فإنكل تبللها مـــع الضـــم واوا

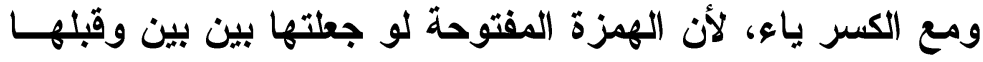

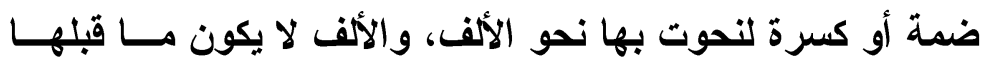

$$
\text { مضموما أو مكسورا. }
$$

r - إذا كاتت مكسورة وقبلها متحرك وأريد تخفيفها جعـــت بـين بــين

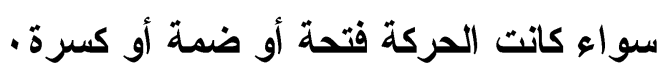

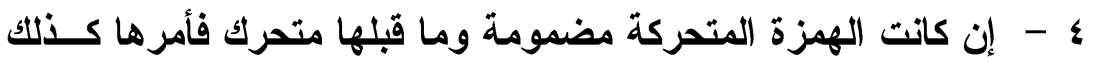

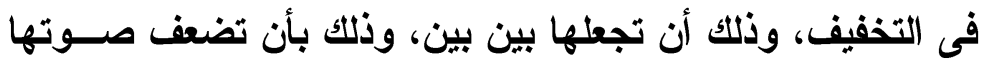

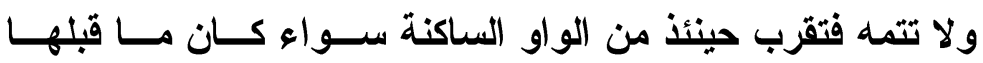

$$
\text { مفتوحا أو مضموما أو مكسورا. }
$$

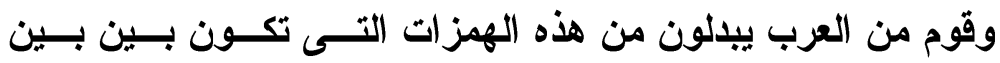

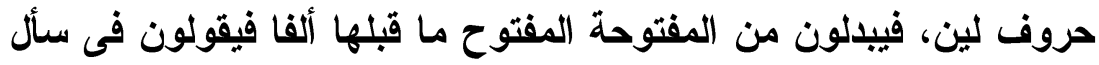

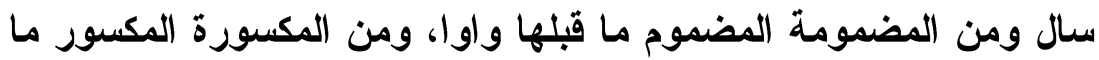

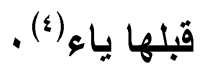

والمواضع التى ذكرت فيها الهمزة المتحركة وقبلها متحرك هى:

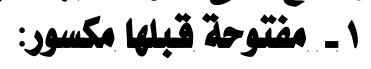

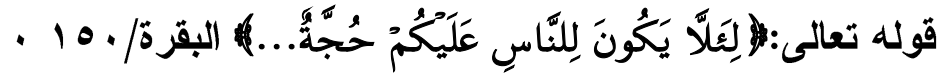

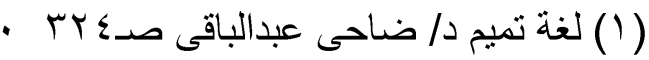

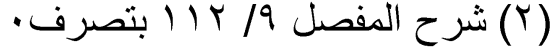

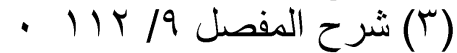

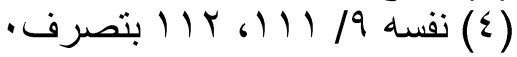




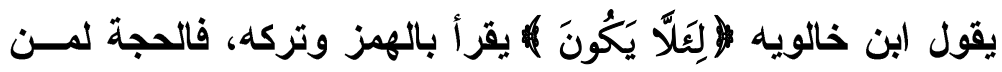

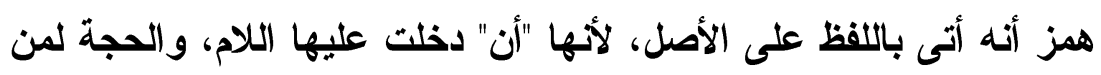

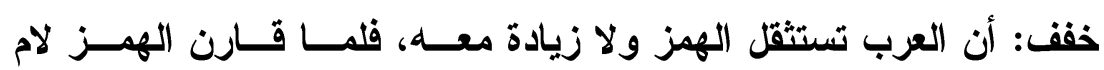

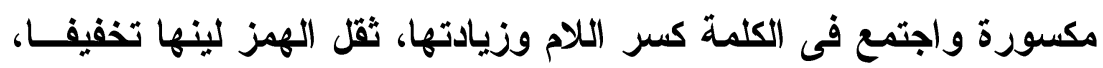

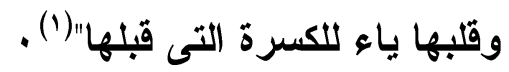
وعن عزو قراعتى الهمز وتركه فى (لتلايل) يقول ابن مجاهد: "روى

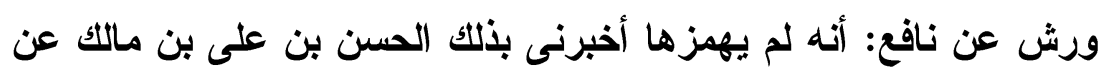

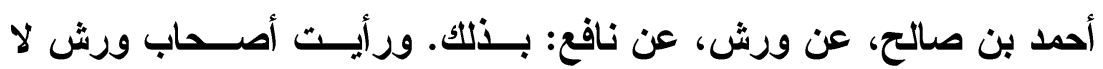

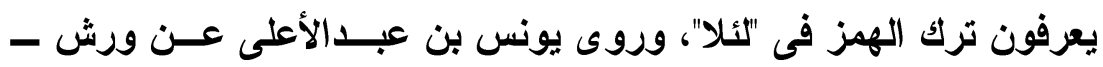

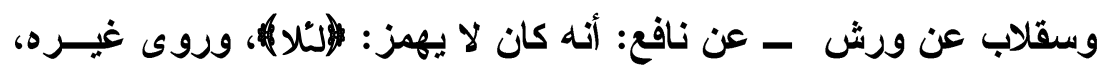

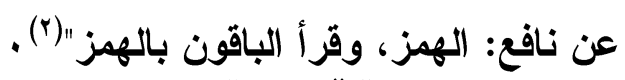

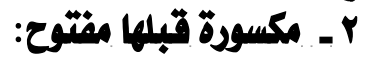

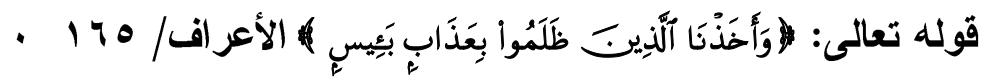

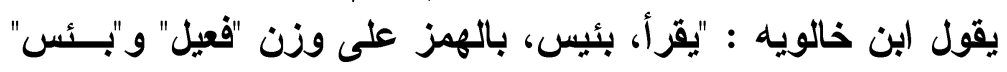

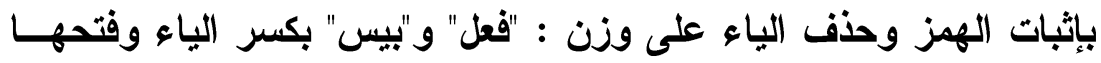

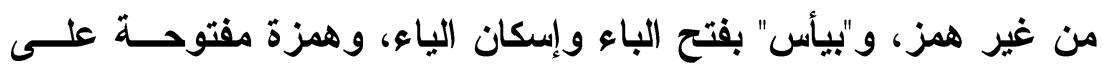

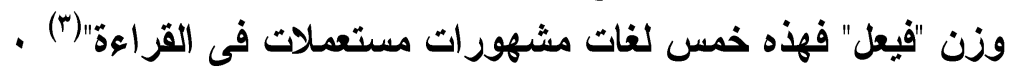
و الأين قرأوا بالهمز على وزن فعيل "بئيس" هم ابن كثير وأبوعمرو فئر

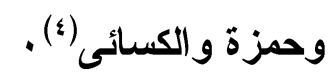
وروى أبوقرة عن نافع: (لبّيس) على وزن فعيل مثل حمزة، وروى

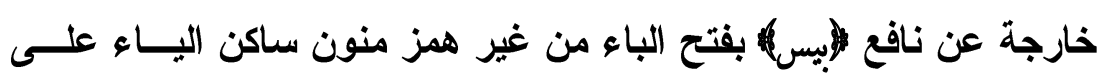

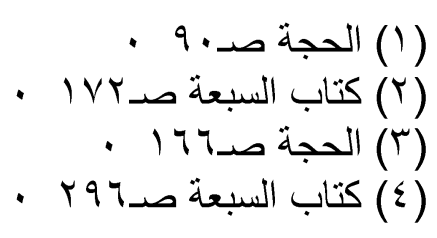




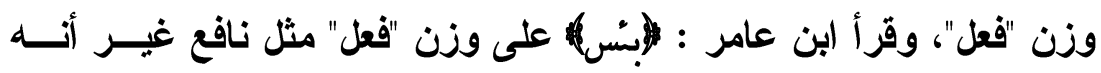

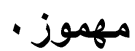

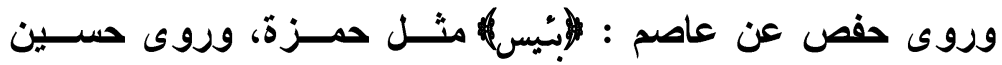

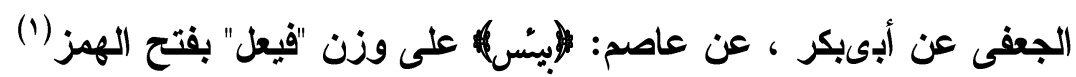

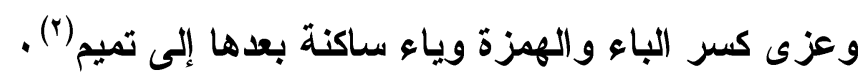

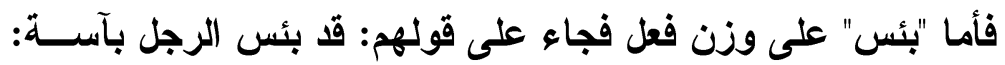

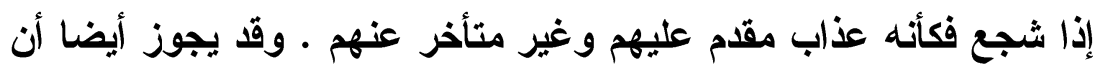

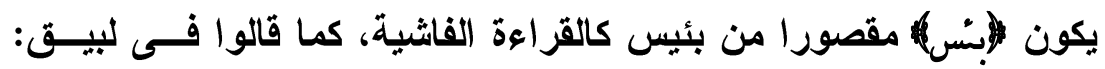

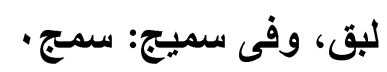

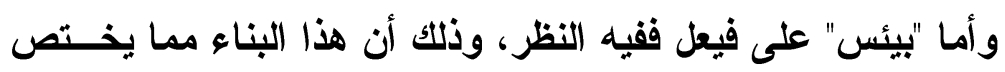

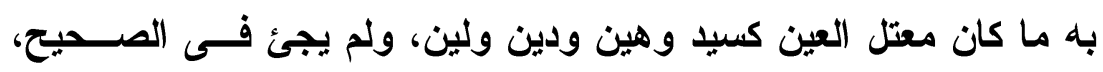

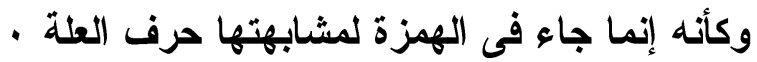

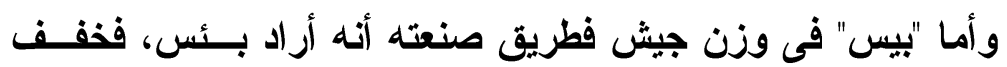

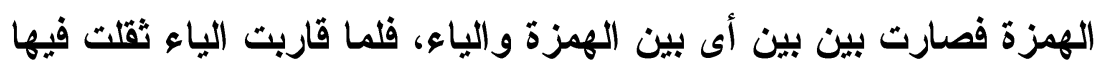

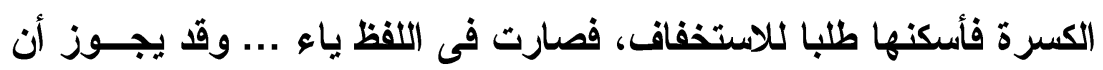

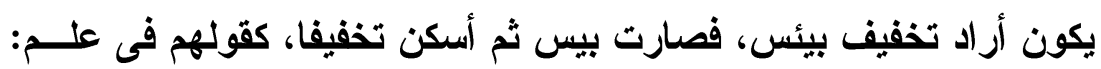

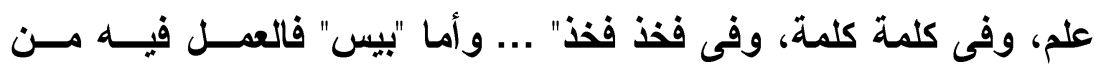

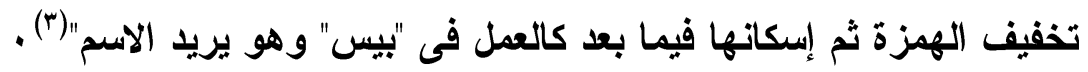

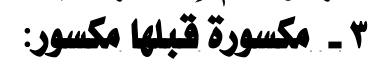

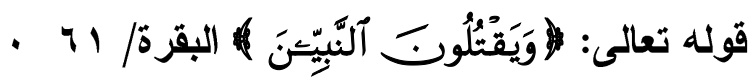

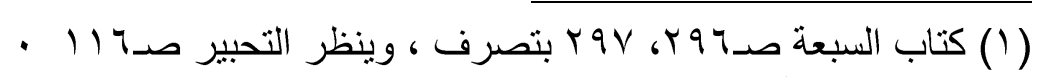

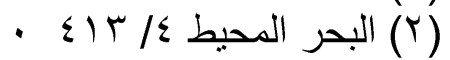

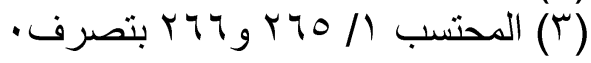


يقول ابن خالويه: "يقرا بالهمز وتركه. وكذلك "النبــوة" و"الأببيــاء"

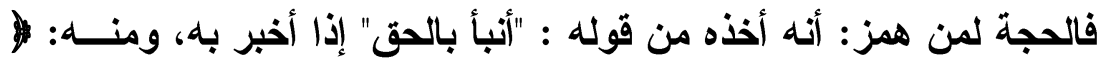

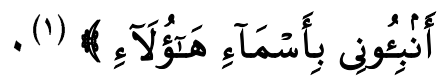

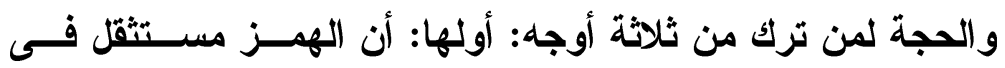

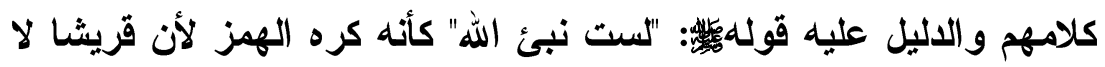

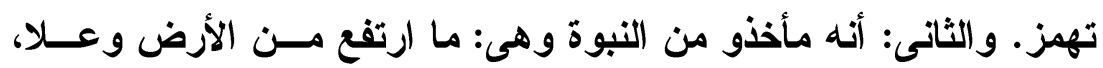

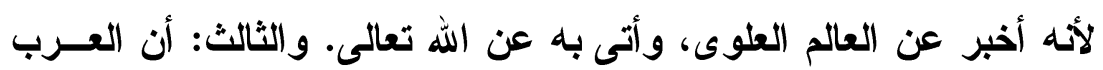

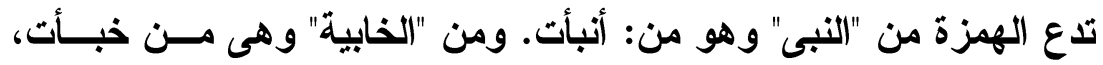

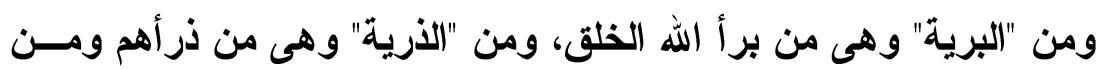

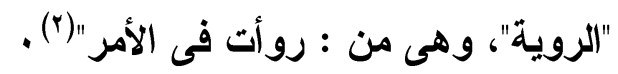

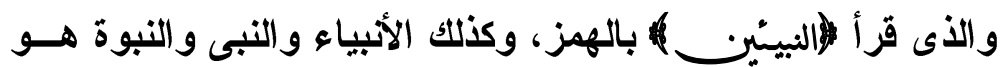

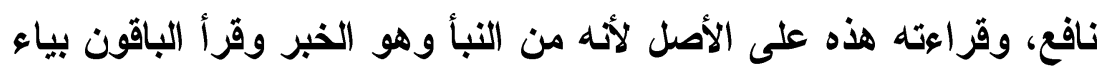

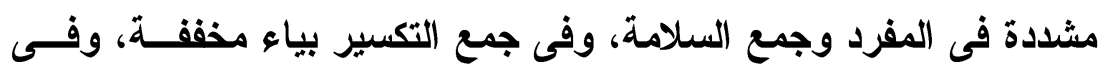
المصدر بواو مثددة مفتوحة (") . .

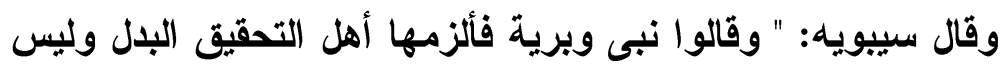

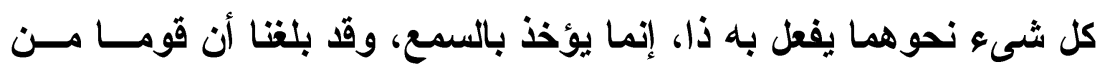

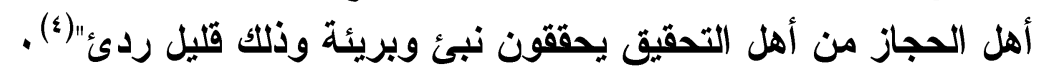

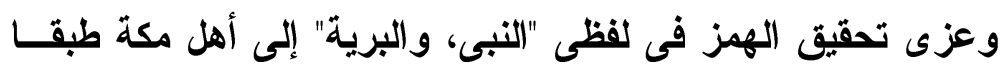

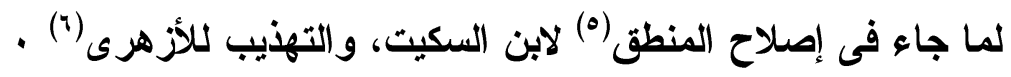

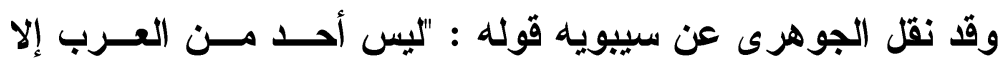
ويقول: تنبأ مسيلمة بالهمز غير أنهم تركوا الهمز فى "النبى" كما تركسـوه التهن

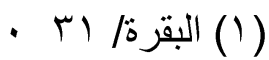

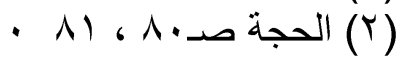

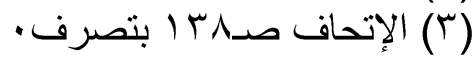

$$
\begin{aligned}
& \text { - }
\end{aligned}
$$

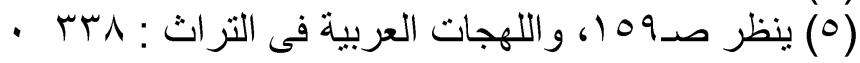

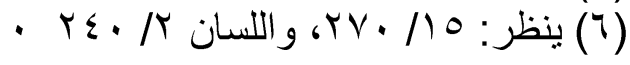


فى الأرية، والبرية، والخابية إلا أهل مكة فإنهم يهمزون هذه الأحرف ولا يهزون فى غيرها ويخالفون العرب فى ذلكي" (1) .

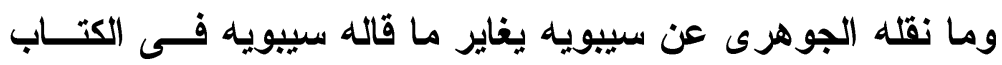

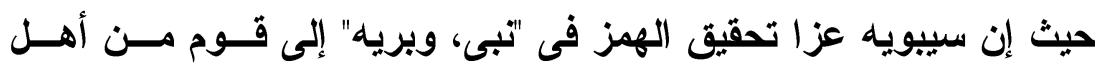

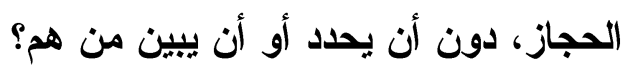

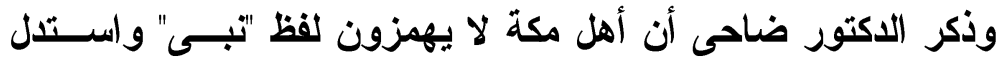

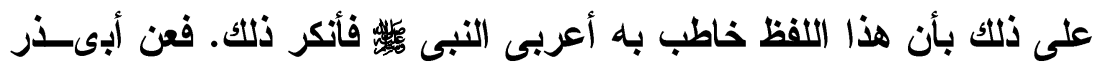

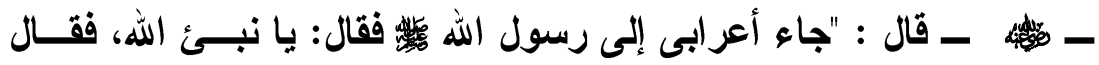

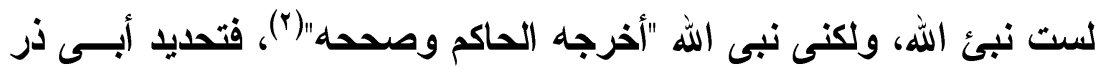

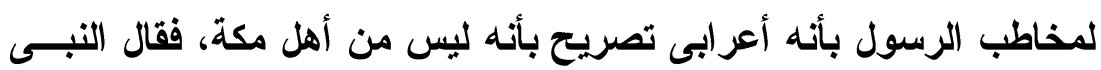

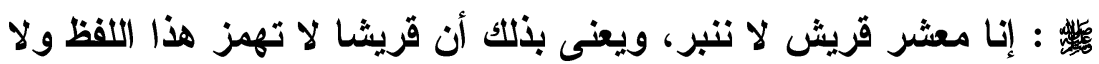

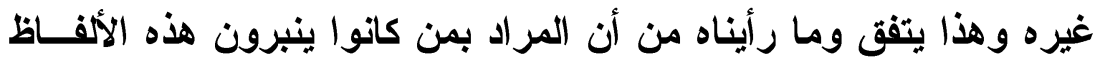

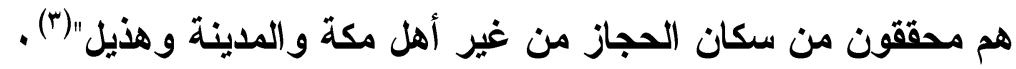

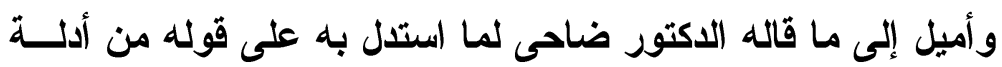

\section{مقبولة .}

$$
\begin{aligned}
& \text { 8 - مضنمومة قبلها مكسور : }
\end{aligned}
$$

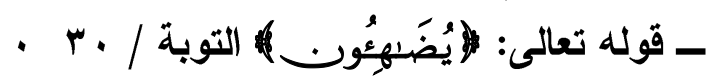

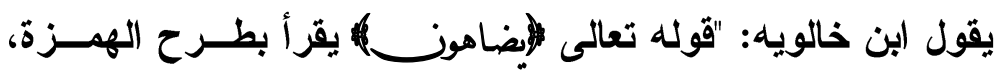

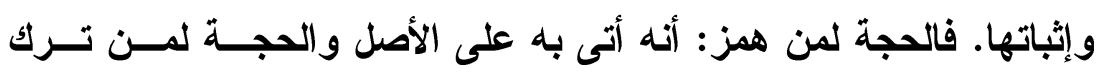

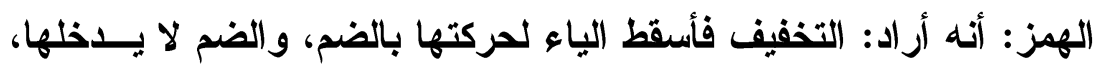

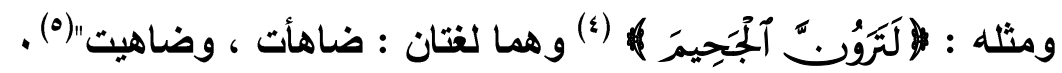

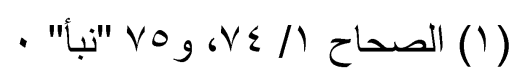

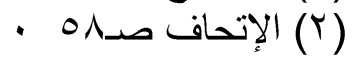

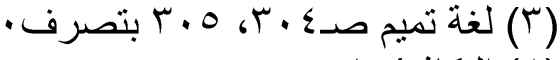

$$
\begin{aligned}
& \text { - } 7 / \text { / } 1 \text { / ( }
\end{aligned}
$$

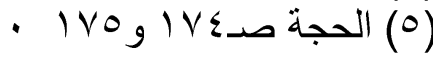




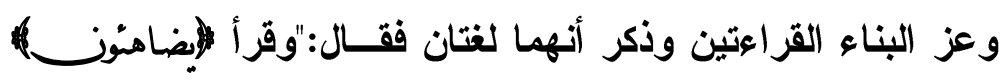

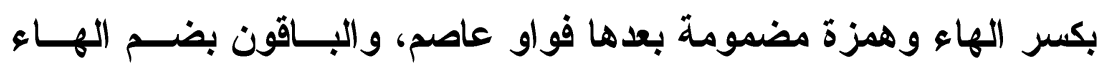

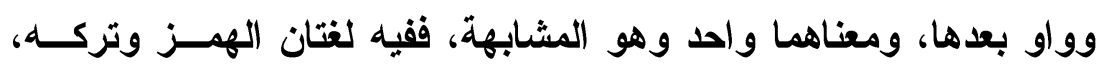

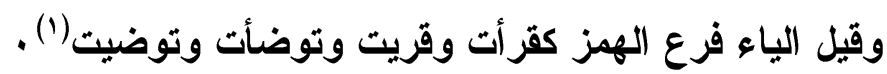

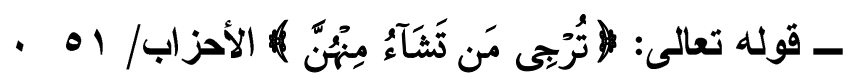

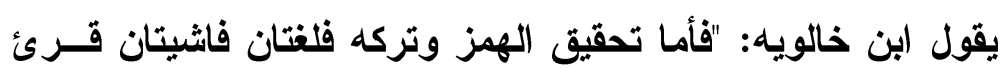

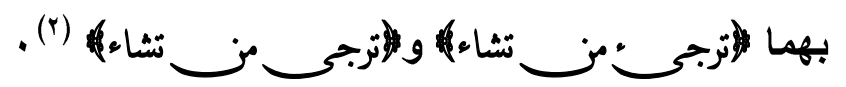

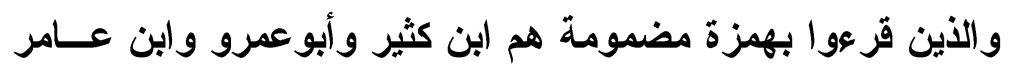

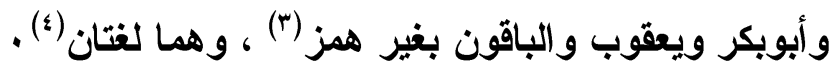

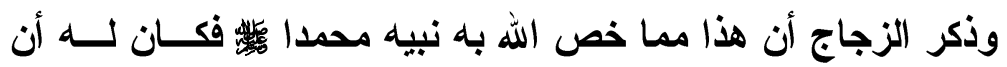

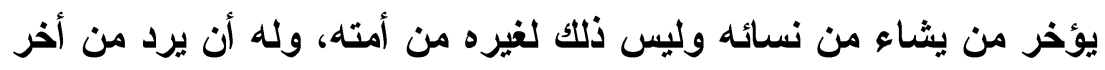

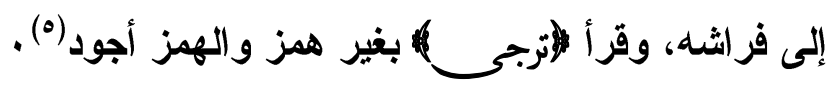

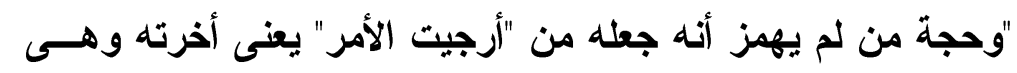

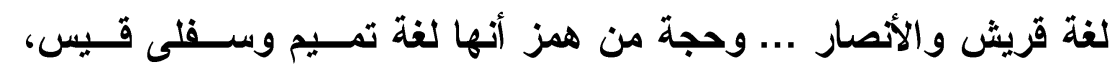

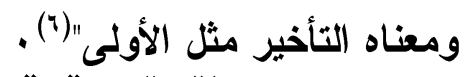

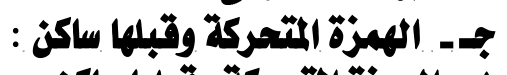

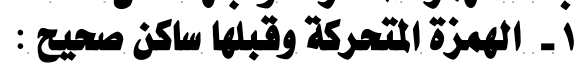

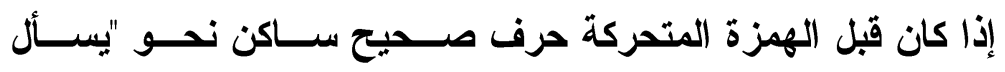

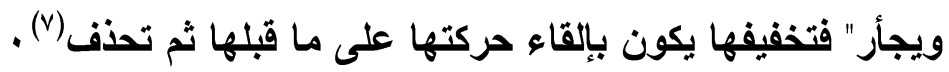

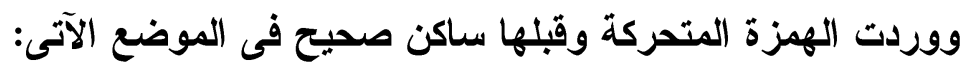

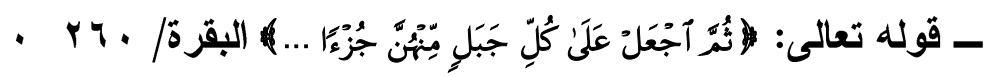

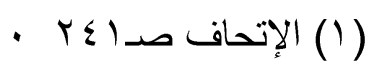

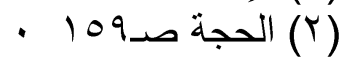

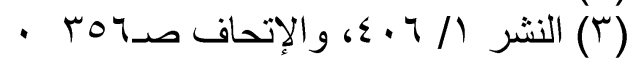

$$
\begin{aligned}
& \text { - } 98 / 0 \text { ( } 10
\end{aligned}
$$

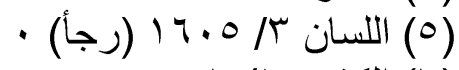

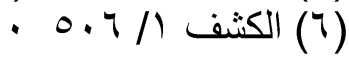

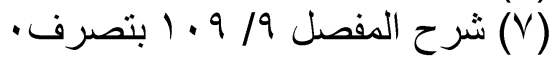




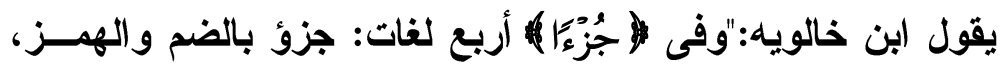
وجزء بالإسكان والهمز، وجزو بالإسكان و الواو، وجزو بضم الزاى والواو

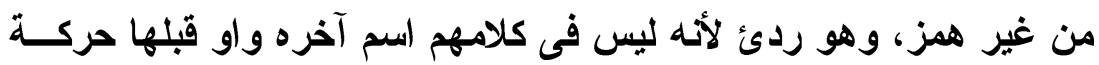

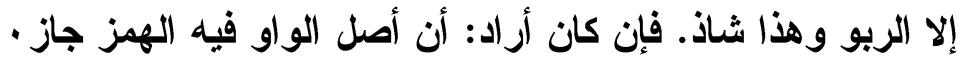

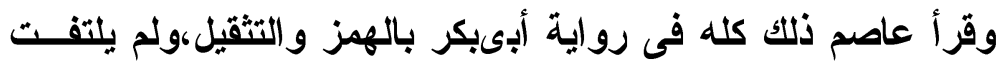

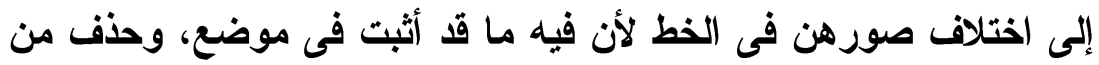

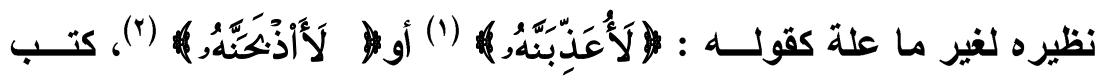
الأول بغير ألف، والثانى بزيادة ألف ولفظهما واحد، فحملـهـه علــى هـــا.

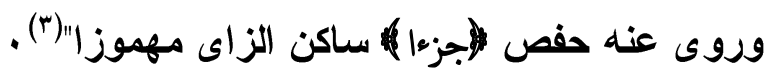
و الأين قر عوا بالإسكان والهمز لمجزء) هم (بــن كثيــر وأبـوعمرو

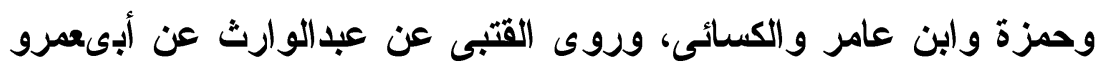

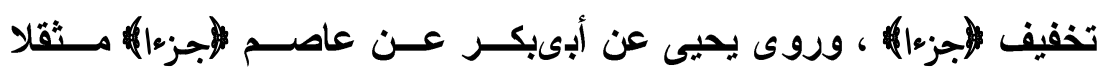
مهوز اوروى حفص عن عاصم (لجزء) مخففا مهموزا وكذلك روى عنه

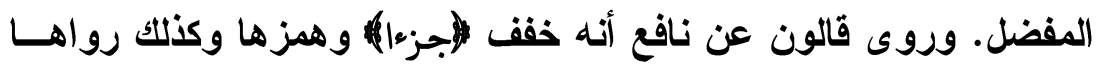

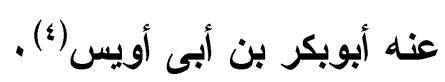

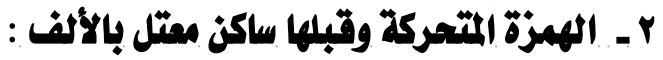

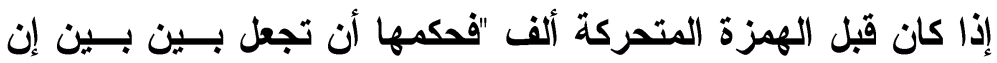

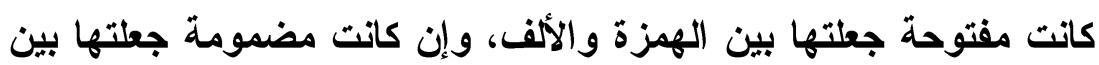

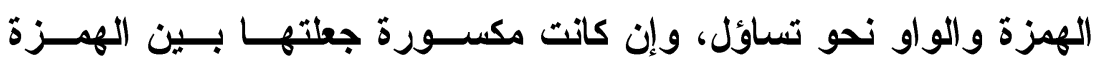

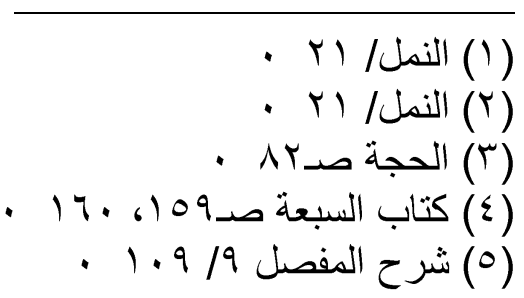


وقد وردت الهمزة المتحركة وقبلها ساكن معتل "ألف" فى الموضعين

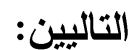

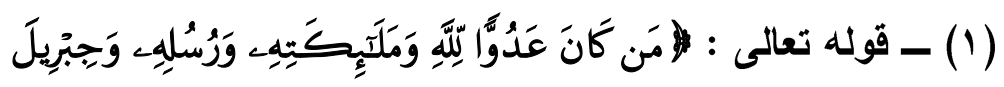

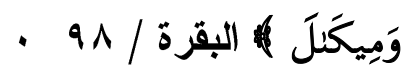

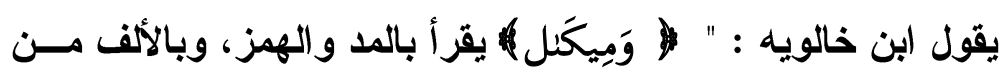

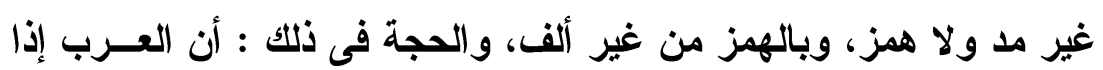

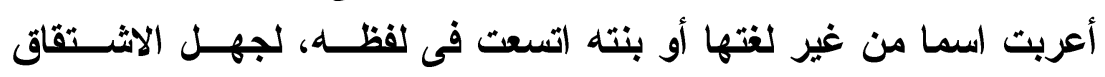

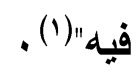

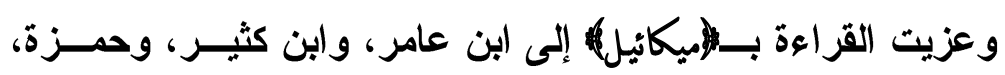

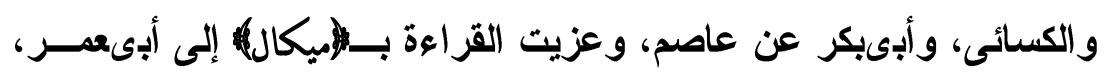

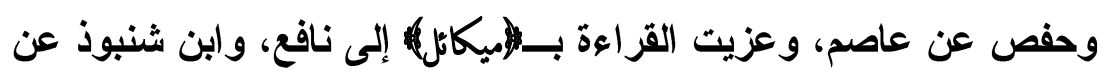

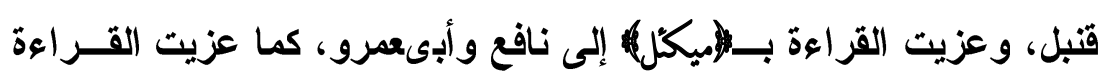

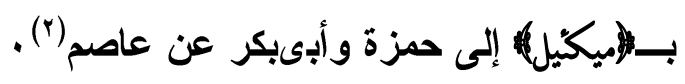

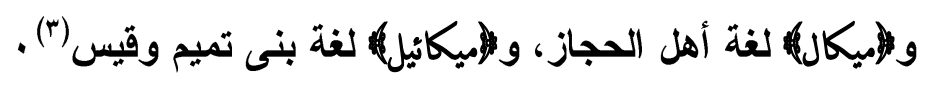

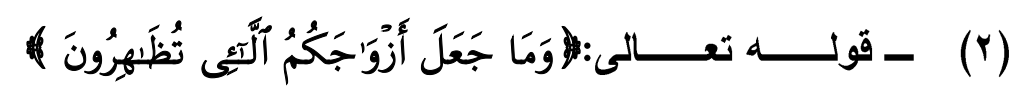

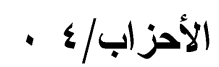

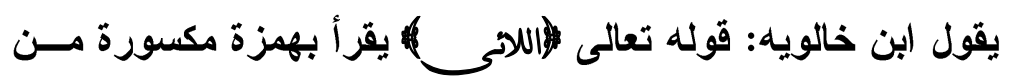

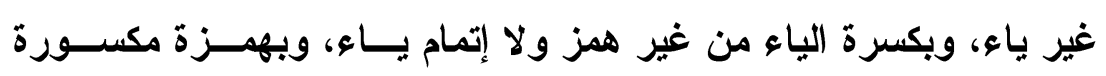

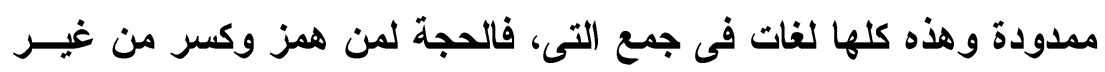

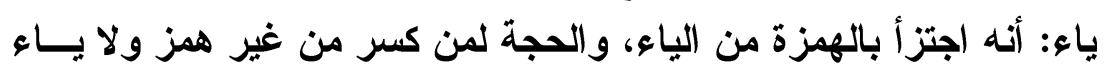

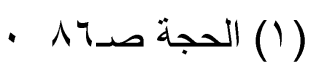

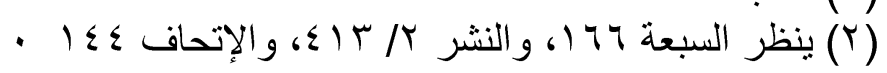

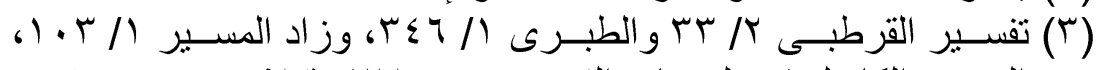

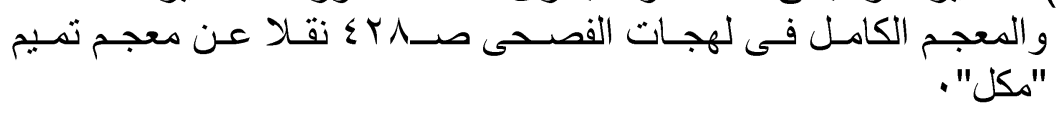




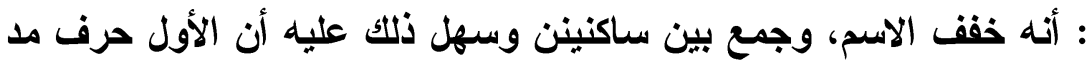

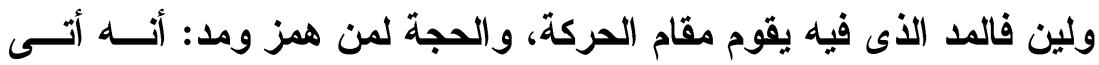

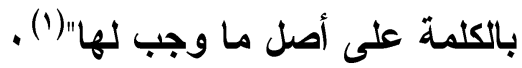

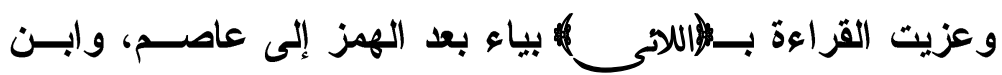
عامر، وحمزة، والكسائى، وعزيت القراعة بــازلاء) ليس بعد الهمزة يــاء

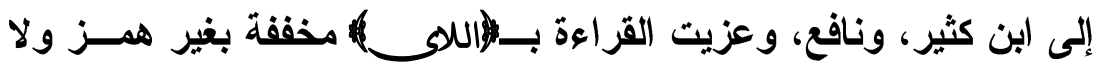
مد إلى ابن كثير فى رواية ابن فليج وإلى أبىعمرو وإلى نافع فى روايــة

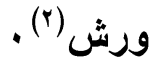

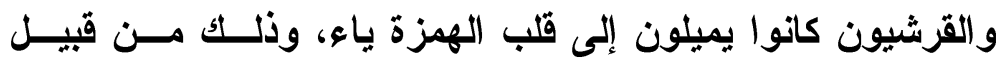

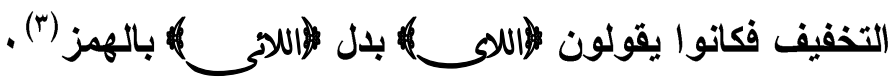

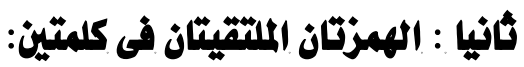

$$
\text { ورد هذا النوع فى الموضع الآتى: }
$$

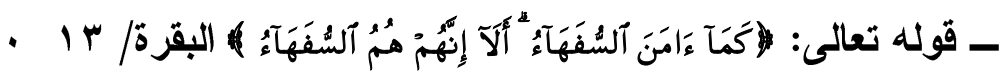

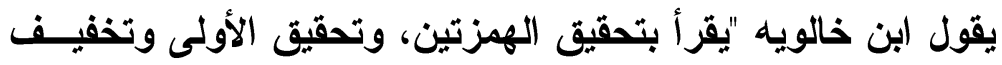

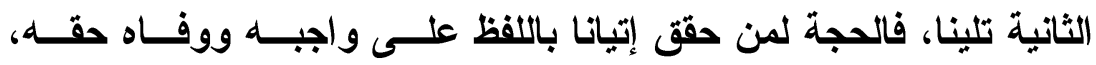

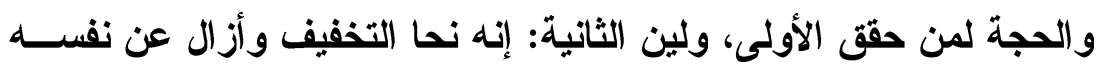
لغة الثقل، فهذا معنى القراعة في الهئ ولئ الهزتين المختلفتين •

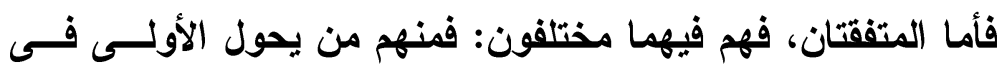

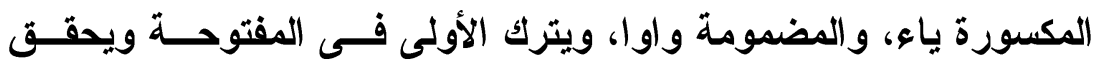

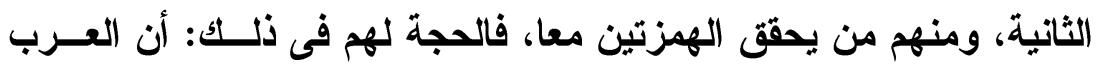

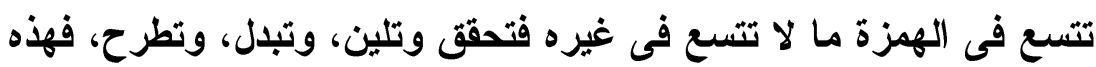

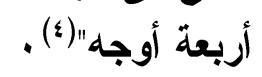

ويتلخص موقف القراء من الهمزتين المتفقتين فيما يأتى:

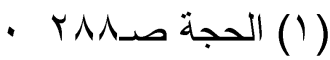

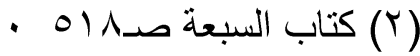

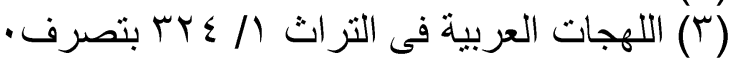

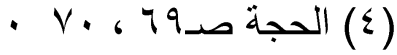




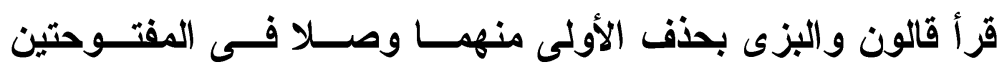

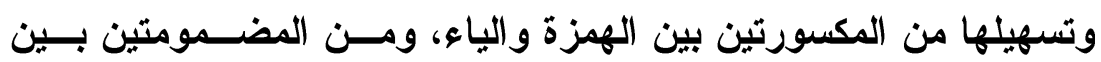

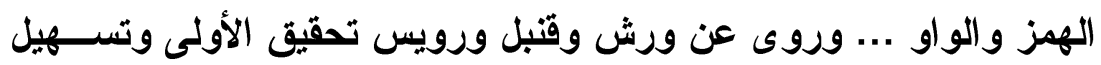
الثانية بين بين فى الأنواع الثلاثة . وروى عن ورش وقنبل وجه آخر هو إبدال الهمزة الثانية حرف مد الثد

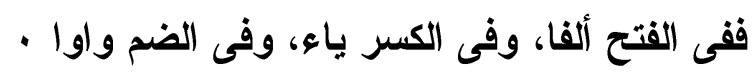

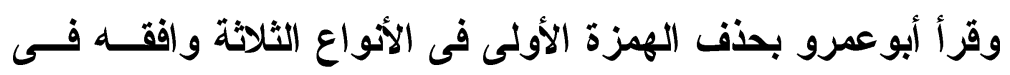
ذلك قتبل ورويس من بعض الطرق ... وقرأ باقى القراء بتحقيق الهمزتين فى الأنواع الثلاثة" (1).

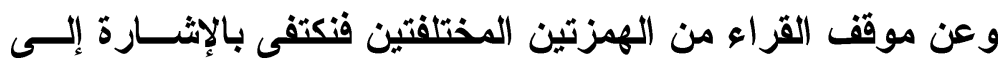

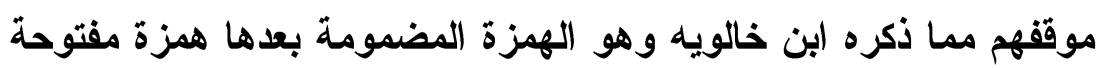

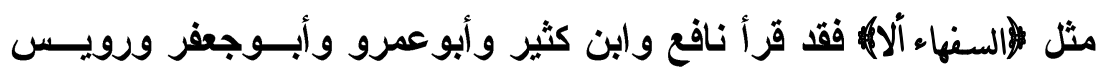

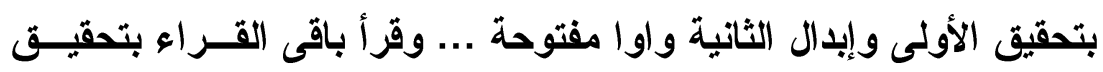

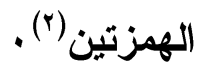

وعن موقف اللهجات العربية من الهمزتين المجتمعتين فى كلمتـين

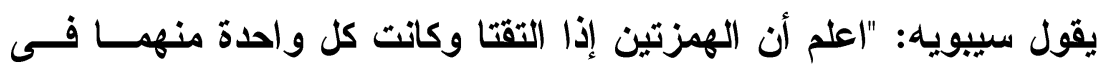

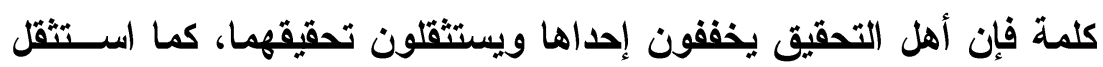

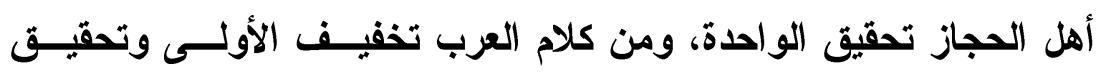

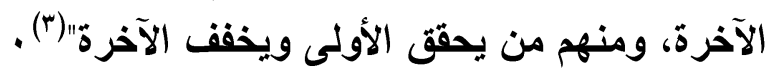

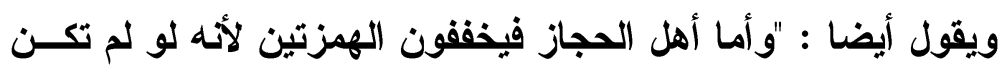

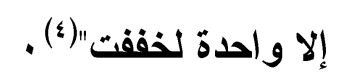

وتحقيقهما جائز لأنهما منفصلتان فى التقاير ولا تلزم إحداهما الأخرى(0).

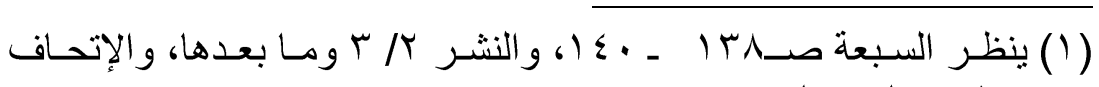

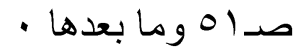

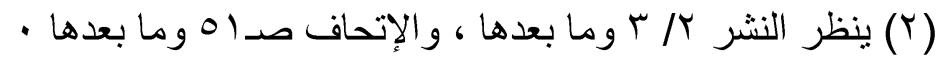

$$
\begin{aligned}
& \text {. }
\end{aligned}
$$

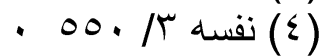

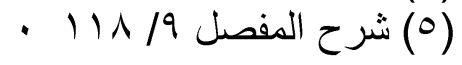




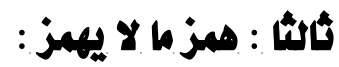

كاتت بعض القبائل العربية لا تكتفى بتحقيق الهمز فقط و إنما كـانوا

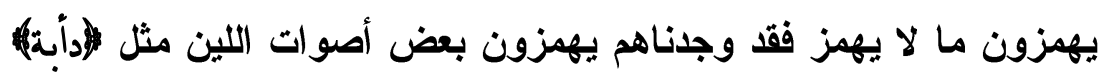
و الشأبة) وغيرها، ومثل هذا يعد من صور المبالغة فى تحقيق الهمز • ولقد تشكك فى ورود بعض صور المبالغة فى تحقيق الهمز الدكتور

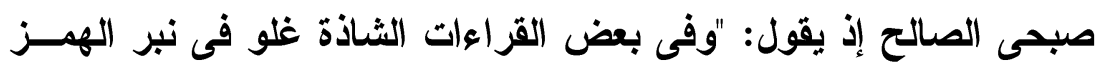

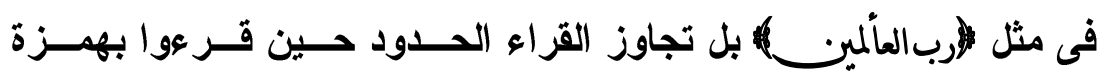
مفتوحة مثل (كعصف مأكول) وبهمزة مفتوحة قبل الحرف المشدد فـى (لولا

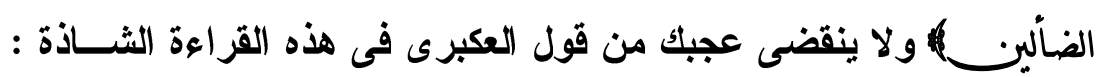

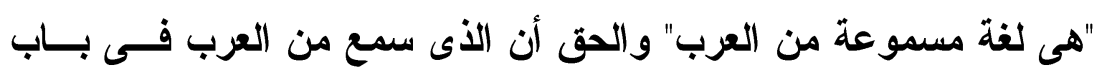

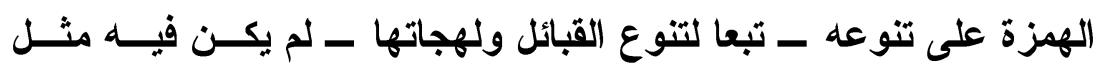

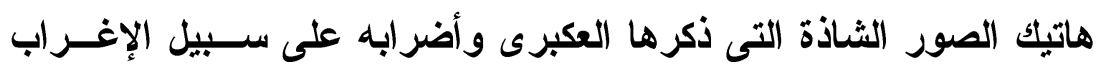

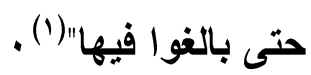

وميع تثكل الدكتور صبحى الصالح فى ورود بعض صور المبالغــة فئة

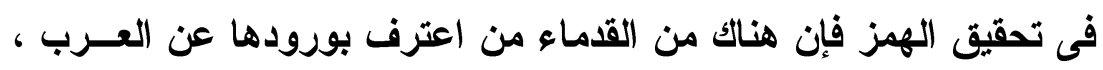

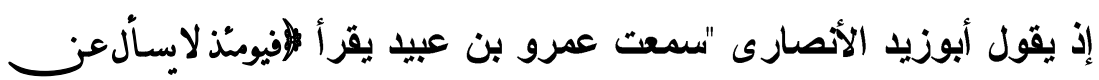

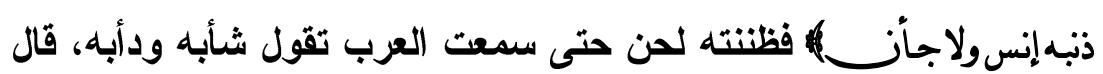

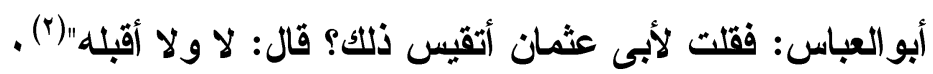

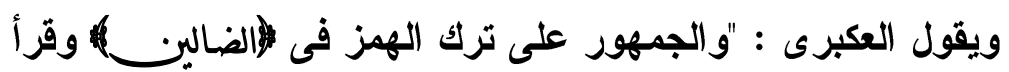

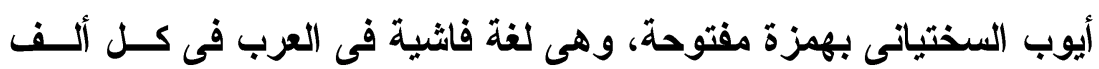

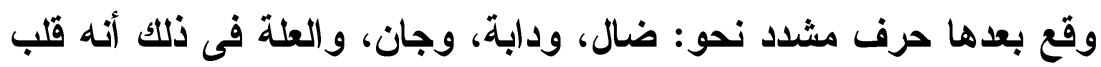

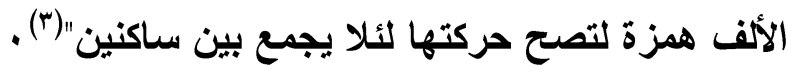


ويقول ابن بعيش : "اعلم أن من العرب من يكره اجتماع الســاكنين

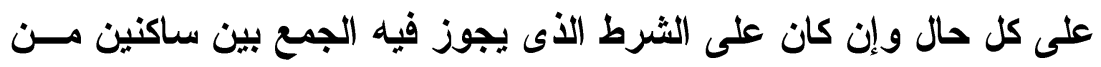

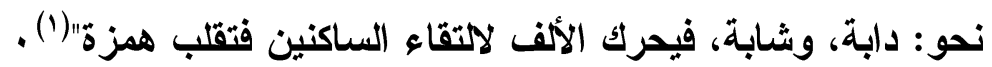

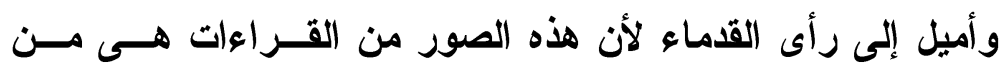

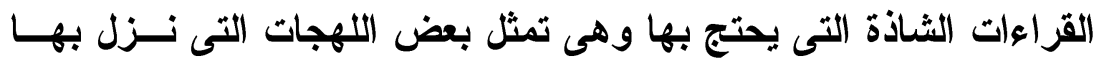

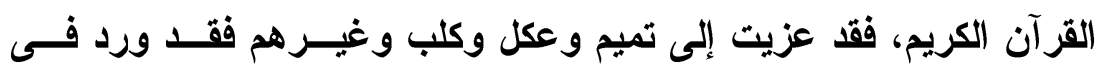

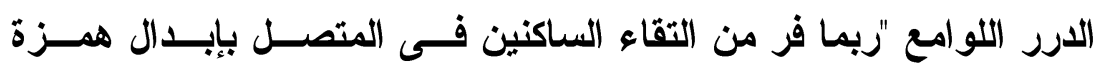

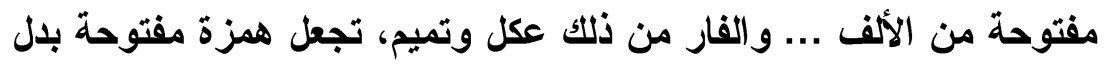

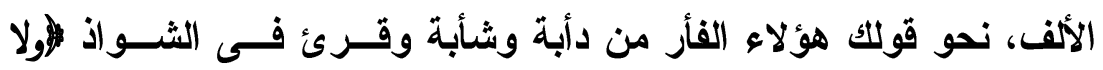

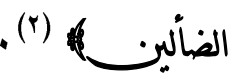
وورد فى لسان العرب عن أبىزيد الأنصارى "سمت رجلا من كلب

يقول: هذه دأبة وهذه امر أة شأبة")(") . وقال ابن منظور: "ووقف عليهما عيسى بن عمر فقال : مأ ما آخذ مسن

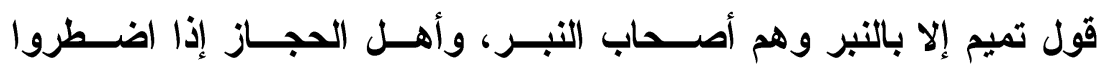

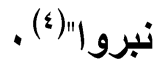
وقد ورد هز ما لا يهمز فى لهجات كتاب الحجة فى الموضع الآتى:

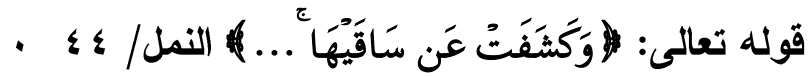

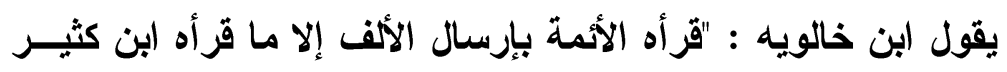

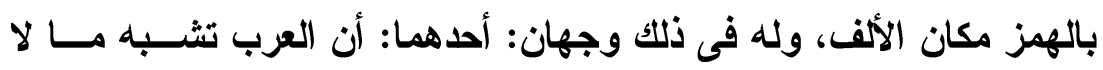

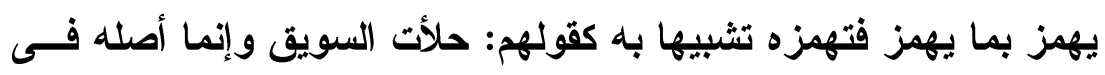

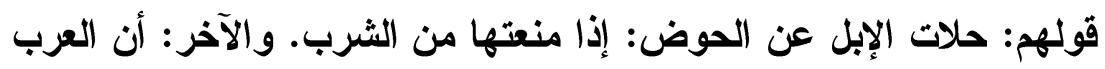

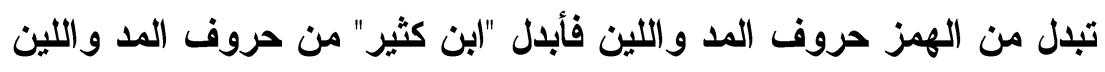

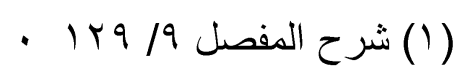

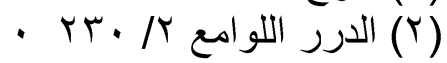

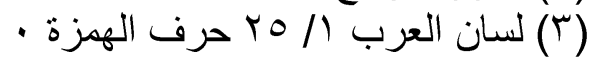

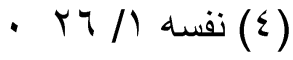




\section{-ะ19.}

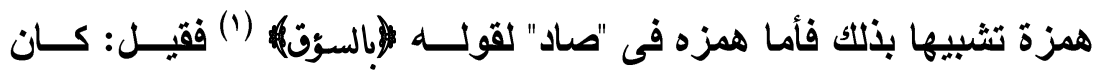

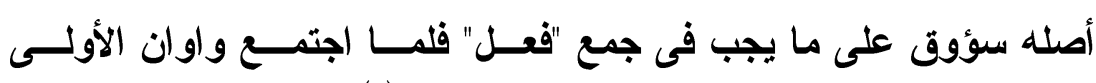

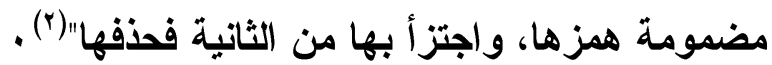
وعزيت القراعة بالهمز مكان الألف إلى ابن كثير وحده وقرأ الباقون

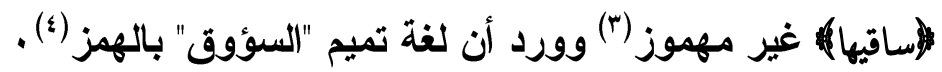

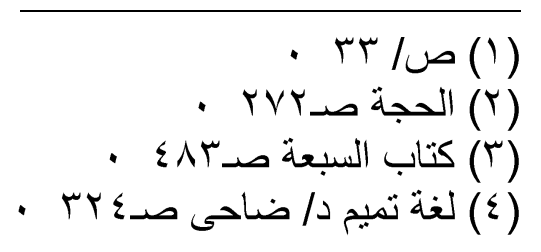




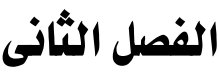 \\ الإبلدال الفيان}

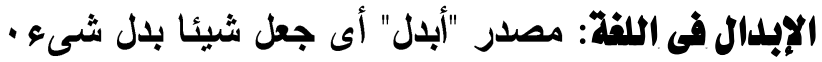

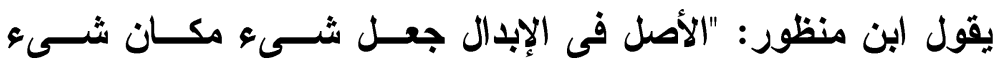

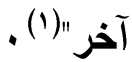

وفى اصطلاح علساء اللفة: "جعل حرف مكان آخر مطلقا"()'، أو حركة

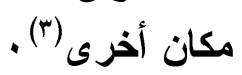

وبذلك يتضح لنا أن الإبدال عند اللغويين يتناول الإبدال فى الحروف لإن

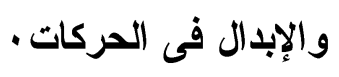

و الإبدال فى الحروف يشمل الإبدال النادر: كقولهم فى "وكنه : وقنته"

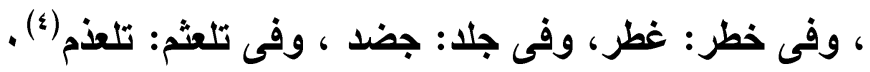

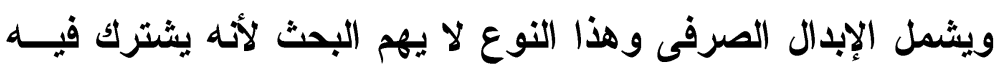

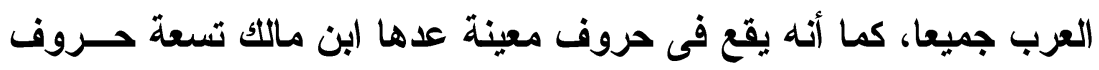

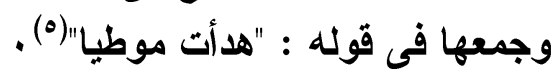

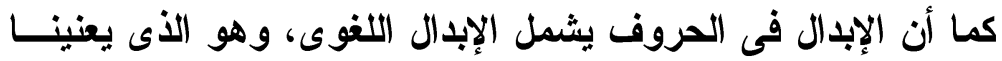

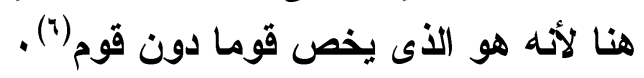

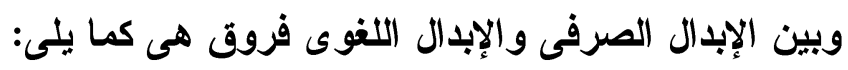

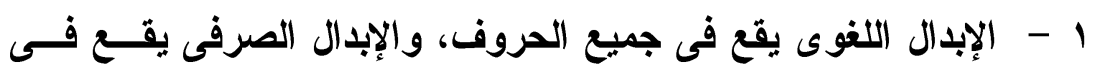

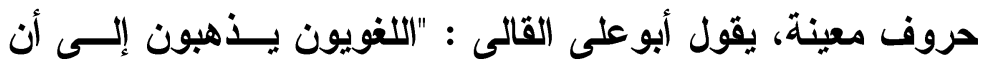

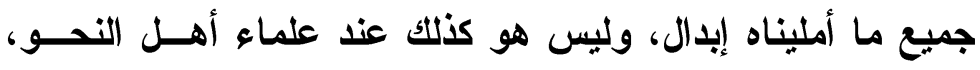

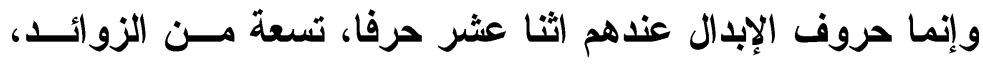

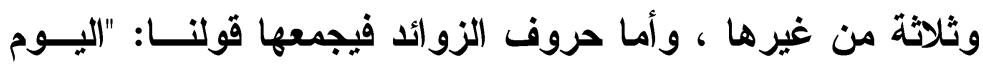

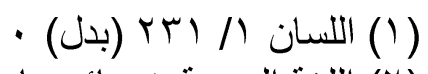

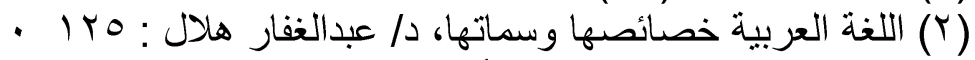

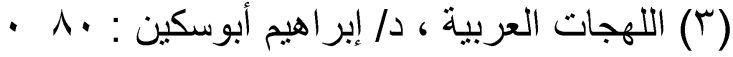

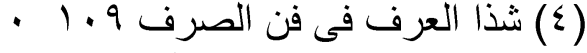

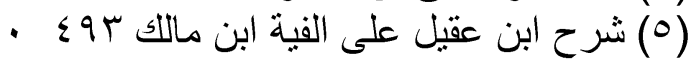

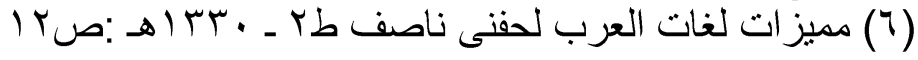


تنساه" وهذا عمله أبوعثمان المازنى، وأما حروف البلال فيجمهــا قولنا: "طال يوم أنجدته" و"هذا أنا عملته"(1) . r - وقيل إن مفهوم الإبدال عند اللغويين، هو جعل حرف مكان آخر مع فع فئه

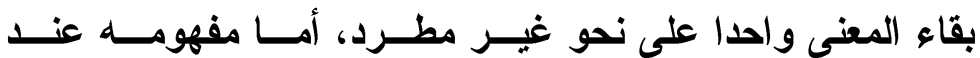
الصرفيين: فهو جعل حرف مكان آخر باطر اداد (؟) . r - كما يختلف الإبدال اللغوى عن الإبدال النحوى فى أن صورتى الكلمة باطنة تستعملان معا عند اللغويين ، فيقال: التهتان، كما يقال: "التهنــال"

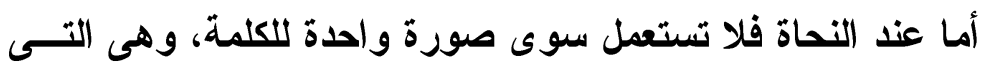

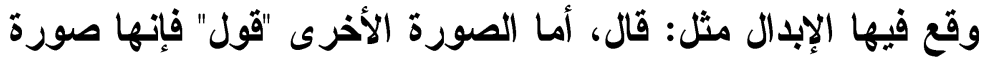

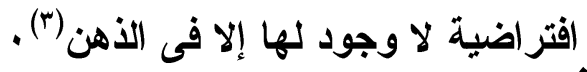

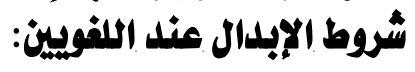

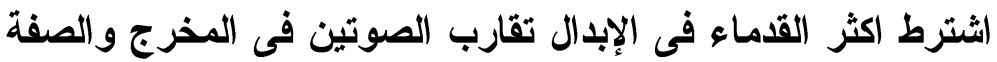

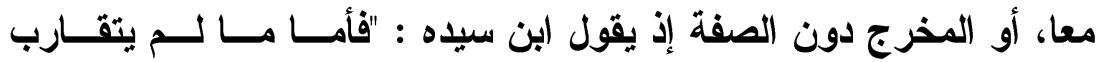
مخرجاه البتة فقيل على حرفين غير متقاربين فلا يسى بدلا، وذلك كإبدال حرف من حروف الفم من حرف من حروف الحلق (๕)" .

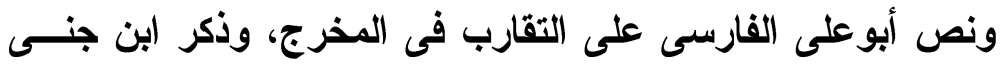

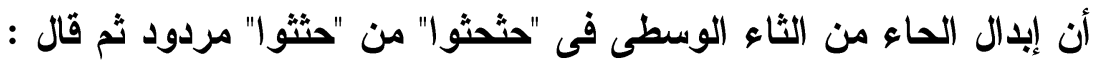

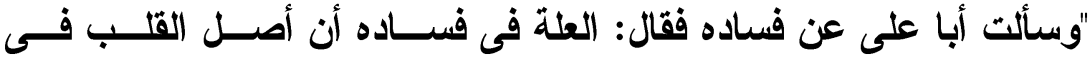

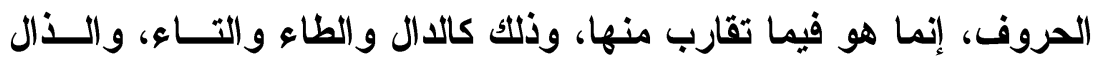

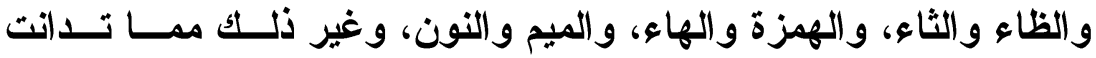

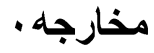

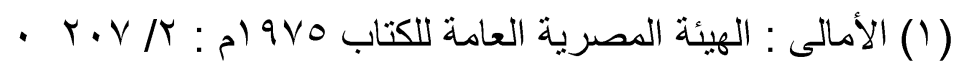

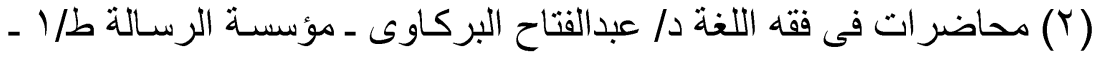

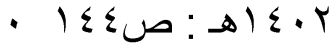

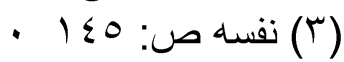

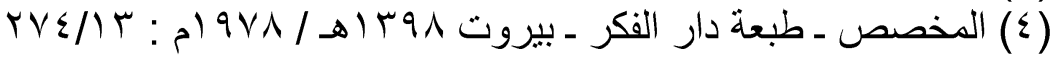


فأما الحاء فبعيدة من الثاء، وبينهما تفاوت يمنع من قلب إحـــاهما

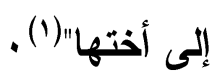
يتضح لنا من ذلك أنه لابد من وجود علاقة صوتية بـين الحــرفين

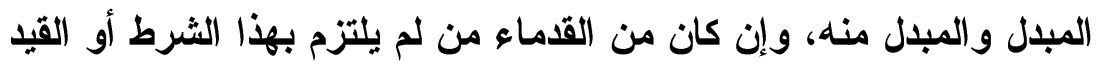

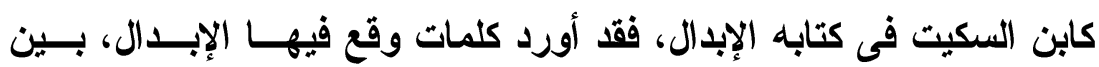

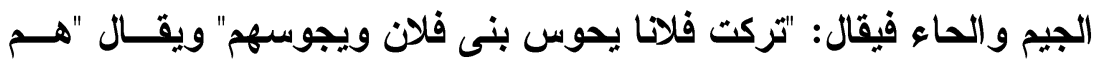

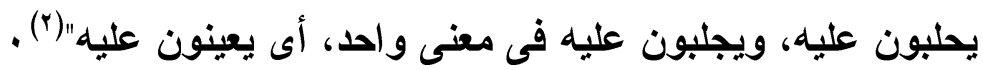

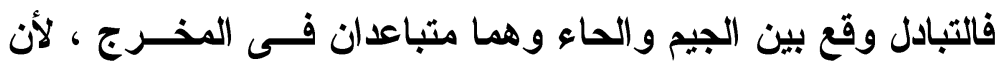

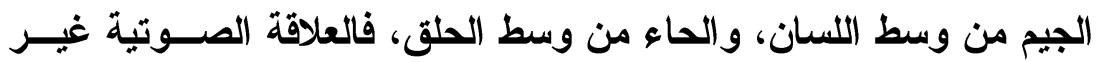

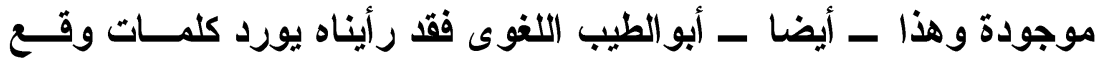

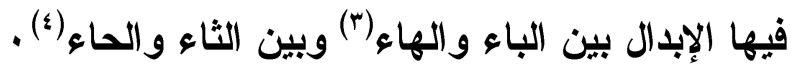

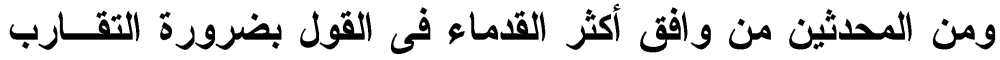
الصوتى شرطا للقول بالإبدال(ه) إذ يرى الاكتور إبراهيم أهن أنيس أن الكلمات

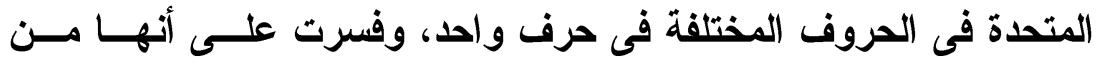

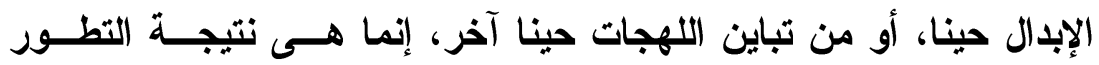

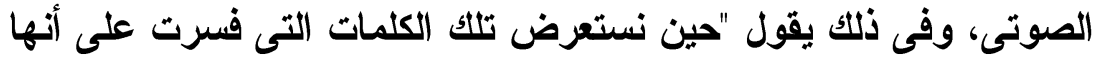

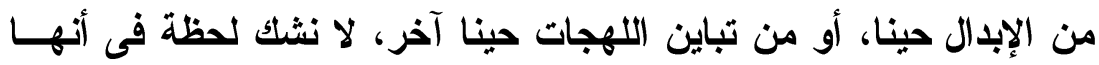

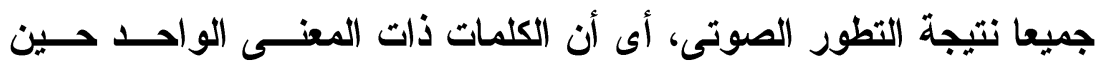

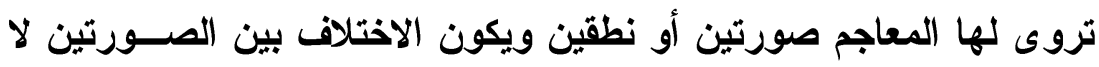

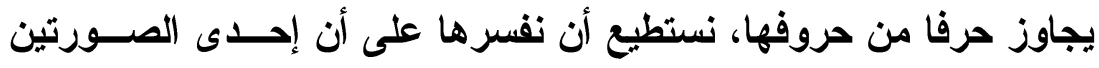

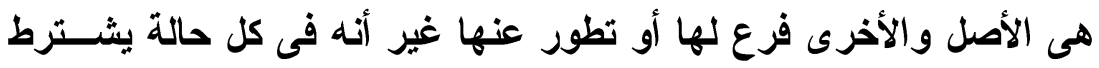

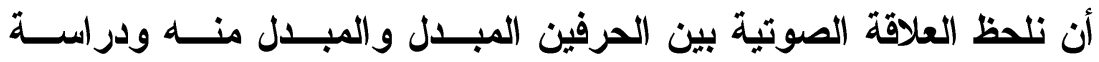

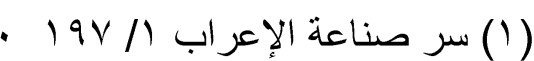

$$
\begin{aligned}
& \text { - 9V : الإبدال لابن السكيت الإعب (Y) }
\end{aligned}
$$

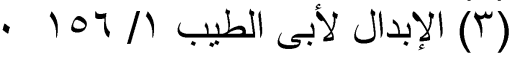

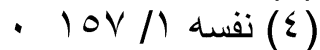

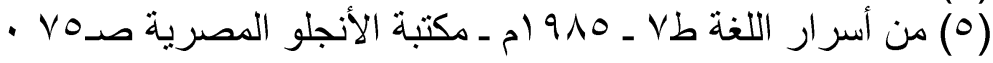


الأصوات كفيلة بأن توقفنا على الصــلات بــين الحــروف وصــفات كـلـ

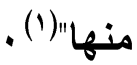
كما أن الاكتور صبحى الصالح وافق القدماء فى القــول بضـــرورة

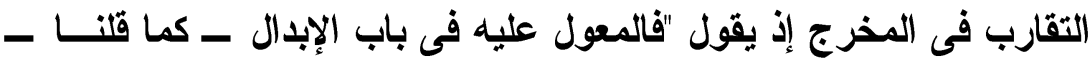

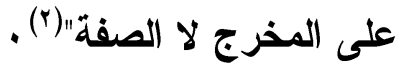

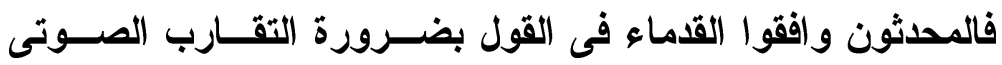

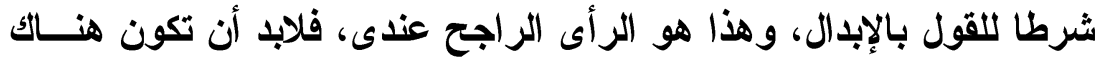

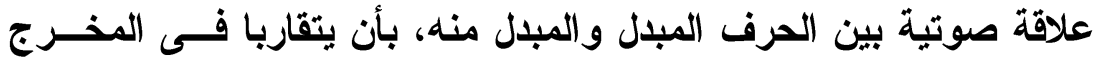

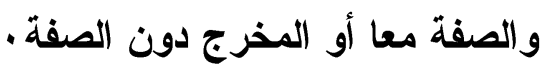

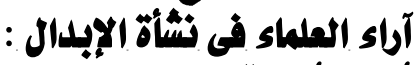
أولا: أنى القداءماء:

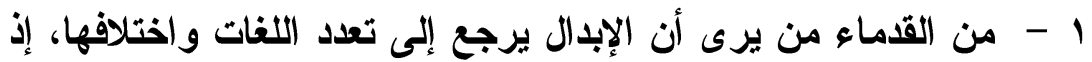

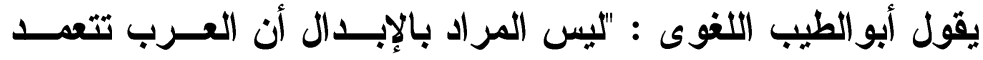

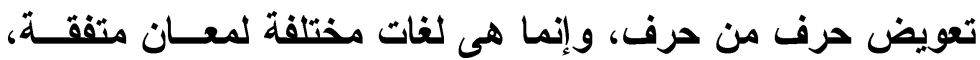

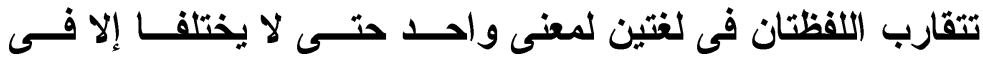
حرف، قال : والاليل على ذلك أن قبيلة واحدة لا تتكلم بكلمة طورا

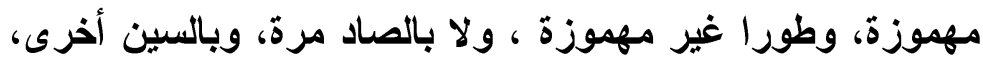
وكذلك إبدال لام التعريف ميما، والهمزة المصدرة عينا كقولهم فى في

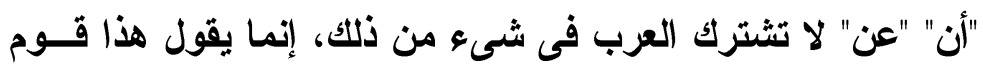

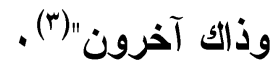

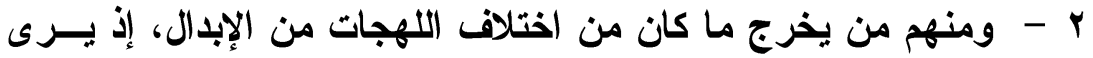

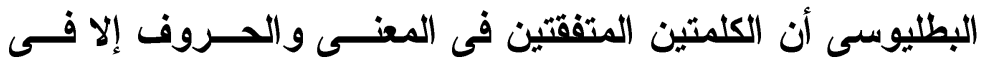
حرف واحد لا يسمى هذا لاختلاف إبدالا إذا كان من لغتين أو أو مسن فئن

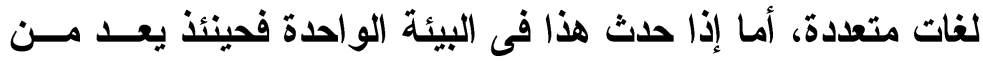

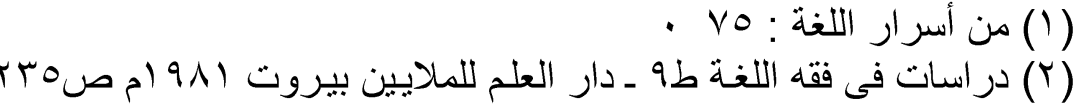


الإبدال إذ يقول : "ليس الألف فى الأرقان ونحوه مبلدة من اليـاء

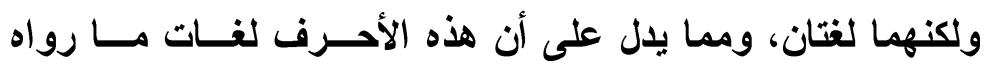

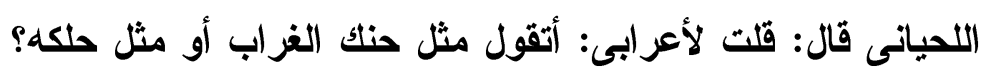

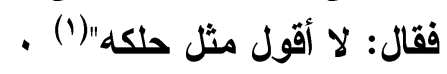
يتضح مما سبق أن أبا الطيب يعتد ما كان من النان اختلاف اللهجات من

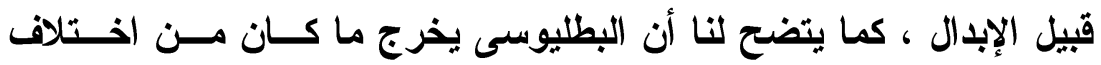

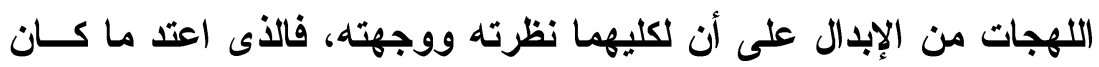

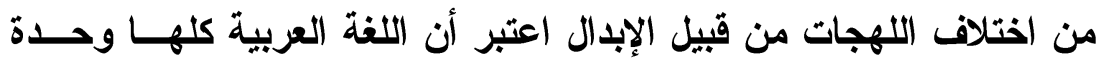

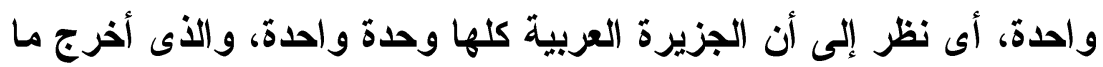
كان من اختلاف اللهجات من الإبدال، اعتبر كل لهجة مستقلة عن الهُ الأخرى وصاحب كل لهجة ينطق صيغة واحدة لا صيغتين مختلفتين •

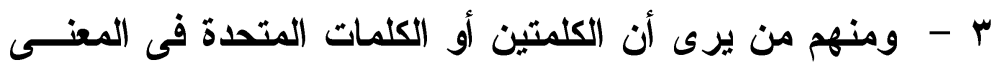

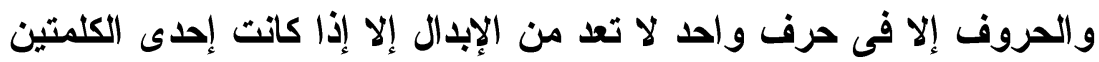

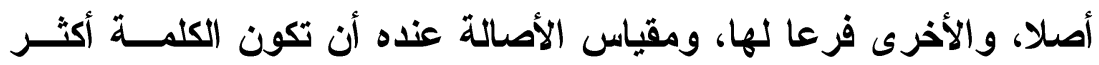

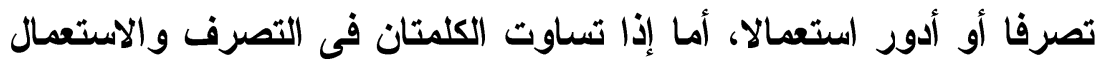

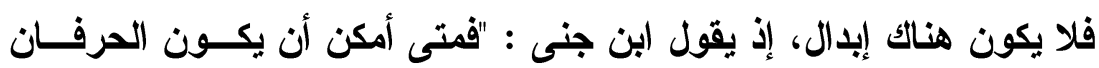

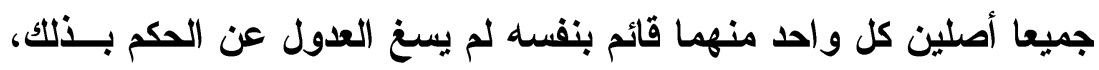

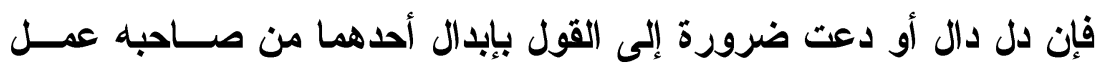

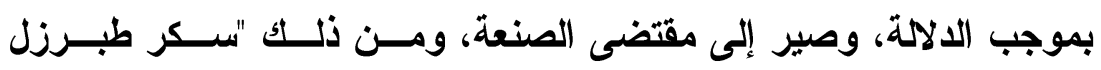

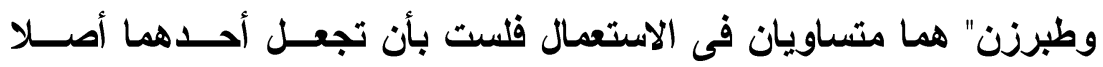

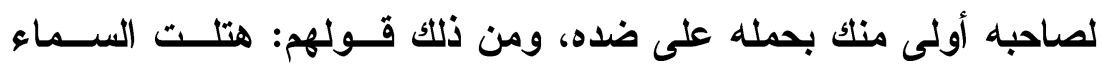

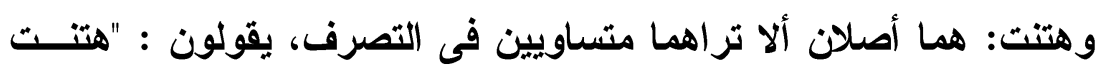

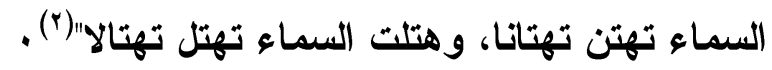

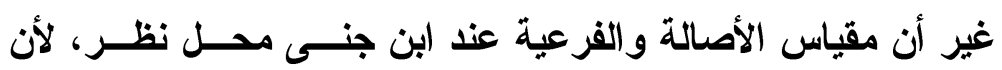

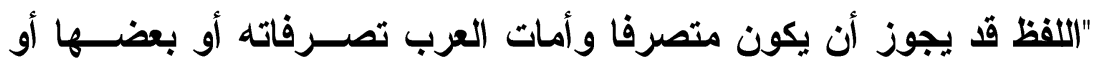


استغنوا عنها، ونحن نطالع فى كتب اللغة أحيانا أن هـــا البـــاء أو هـــه

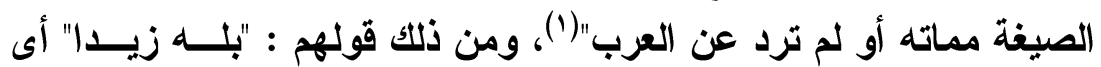

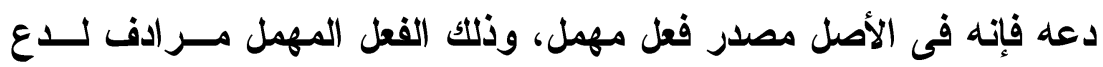

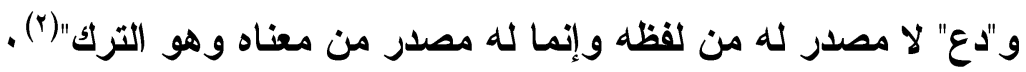

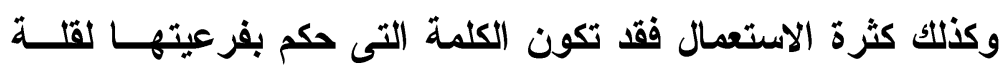

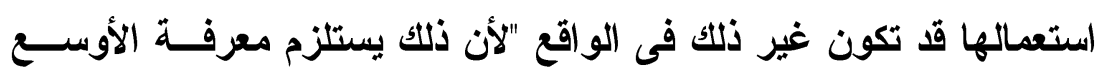

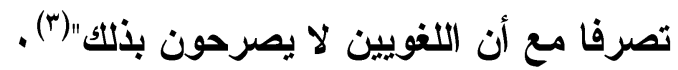

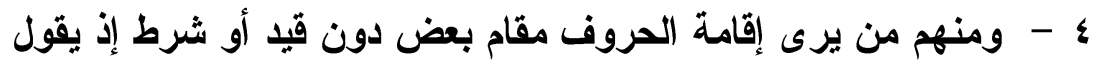

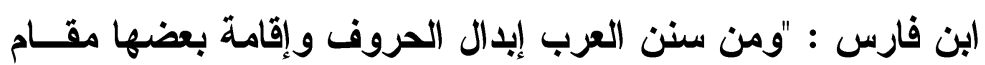

$$
\begin{aligned}
& \text { بعض ... وهو كثير مشهور" (؛) . }
\end{aligned}
$$

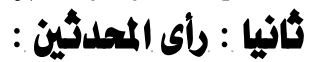

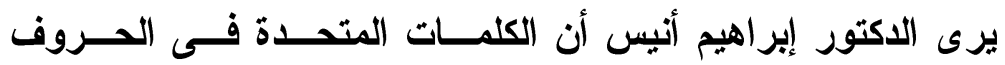

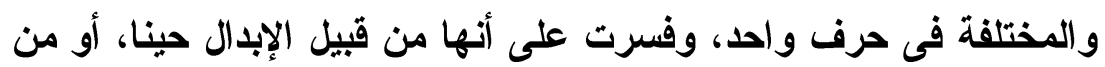

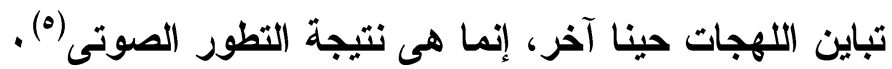

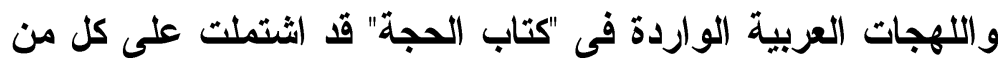

$$
\begin{aligned}
& \text { الإبدال فى الحروف، والإبدال فى الحركات . }
\end{aligned}
$$

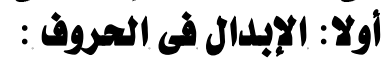

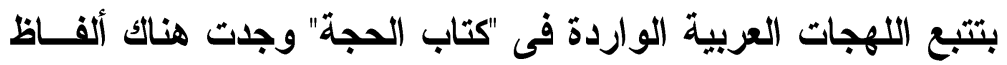

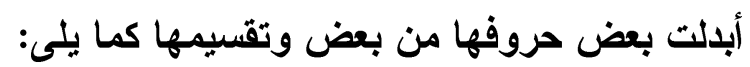

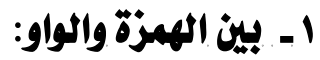

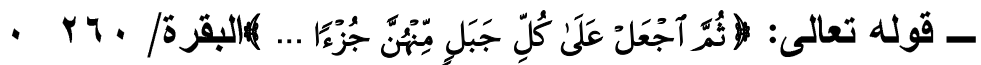

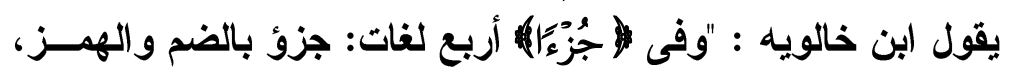

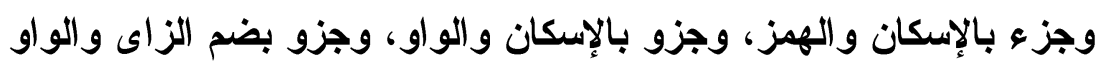

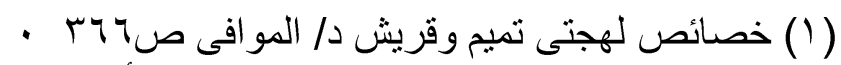

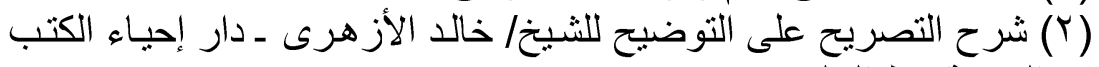

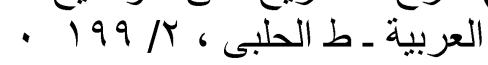

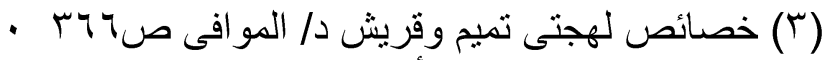

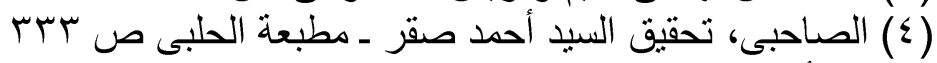

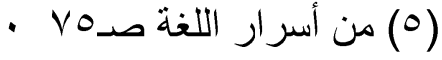




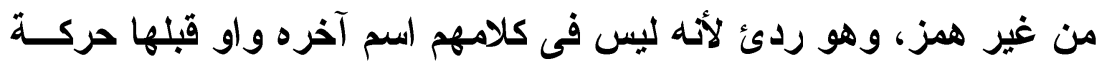

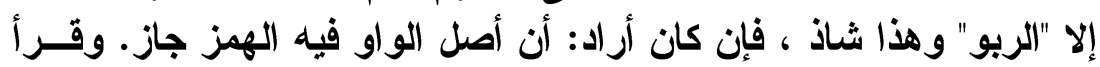

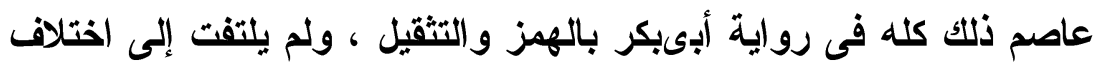

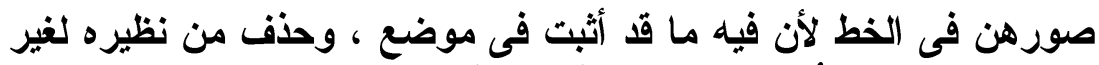

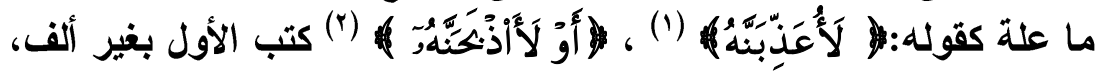

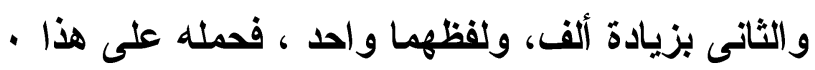

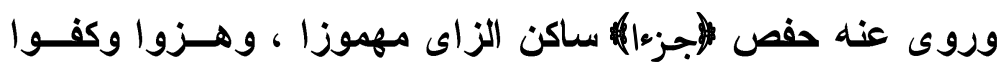

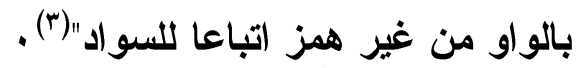

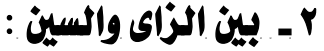

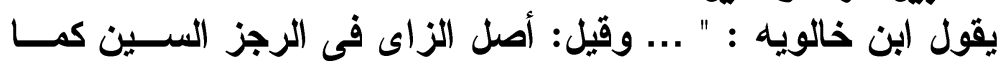

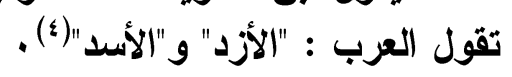

وذكر ابن منظور أن الأسد لغة في الأزد، يقال : "هم الأسد" ، "أســــ

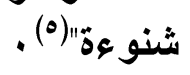

وبين الزاى والسين قرابة صوتية تسوغ الإبدال بينهما فهما متفقان

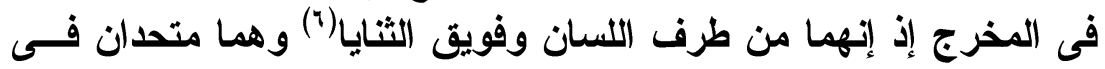

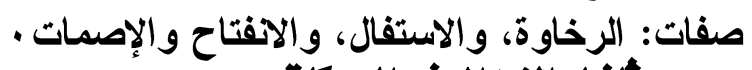

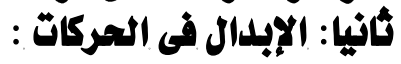

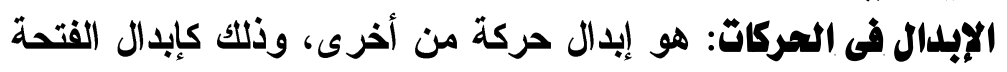

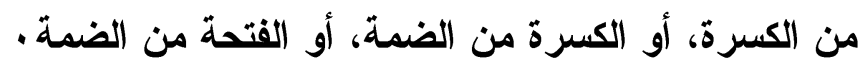

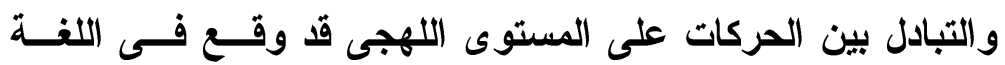

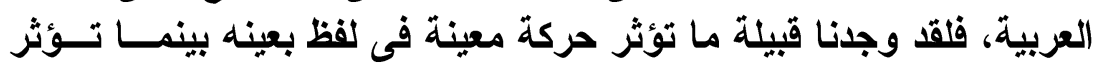

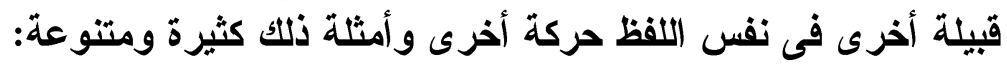

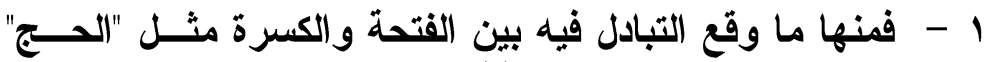
بفتح الحاء لأهل العالية، وبكسرها لنجد(')، ومثل "حصاد" بفتح الحاء لنج ولثد

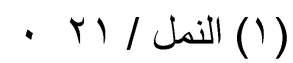

$$
\begin{aligned}
& \text { - r) (r) }
\end{aligned}
$$

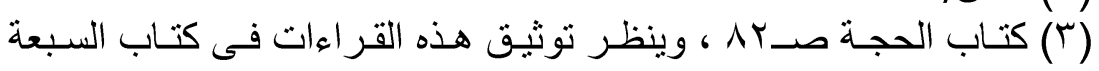

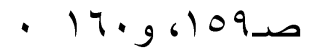

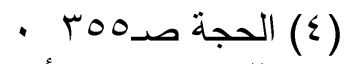

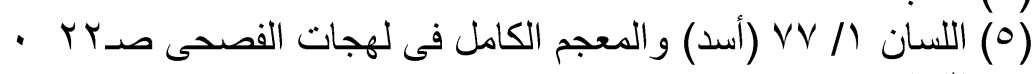

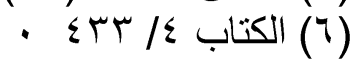




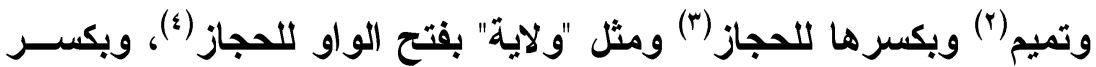

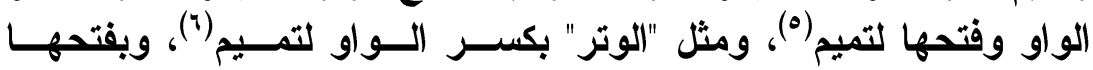

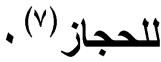

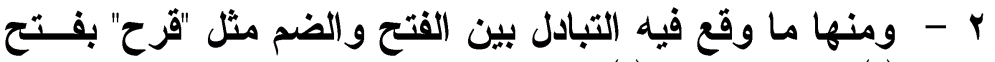

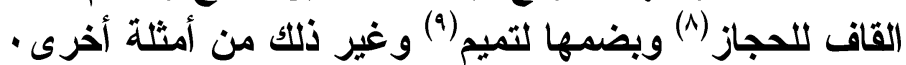

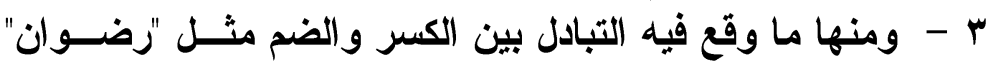

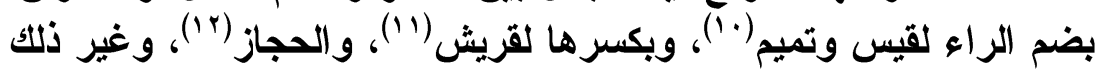

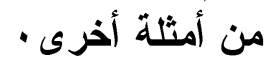

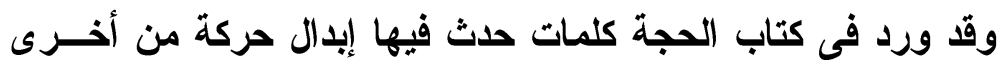

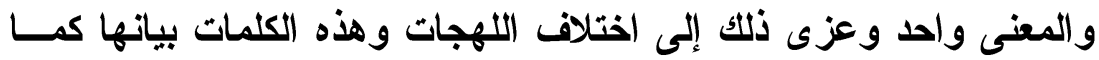

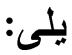

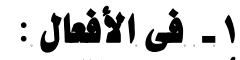

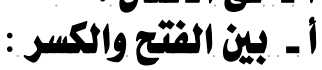

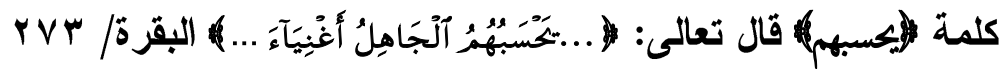
يقول ابن خالويه : "يقرأ بكسر السين وفتحها، فالحجة لمــن فـتح:

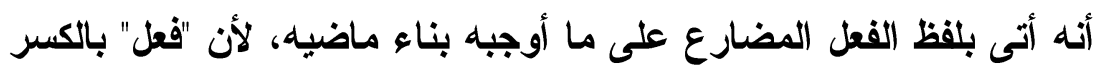

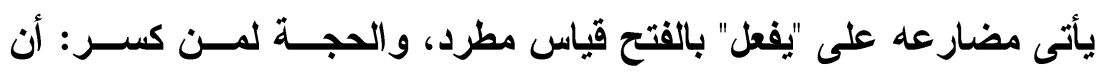

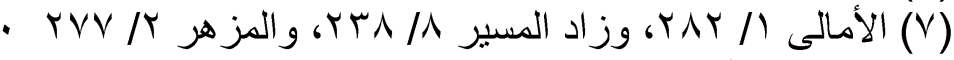

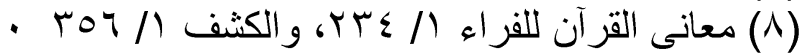

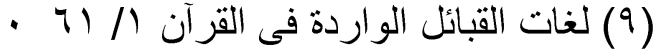

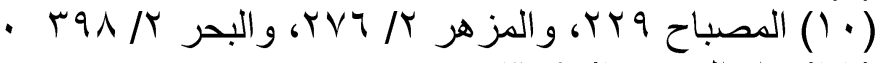

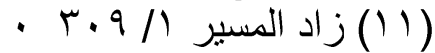

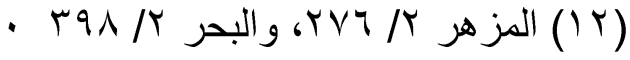




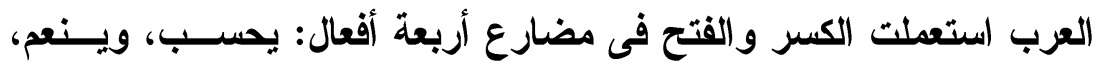

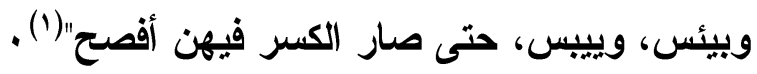

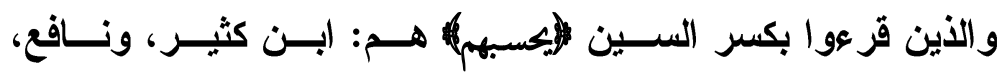

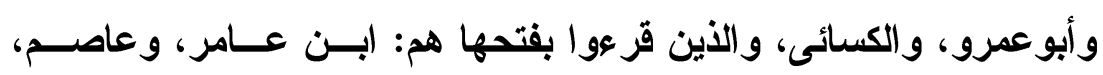

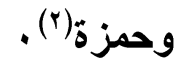

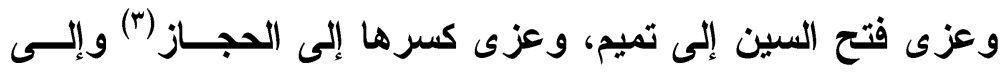

$$
\text { قريش (๕) معزى }
$$

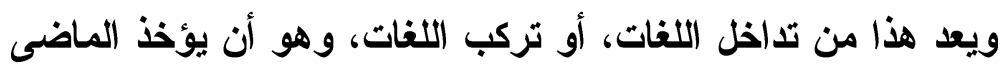

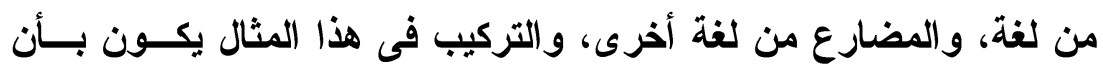

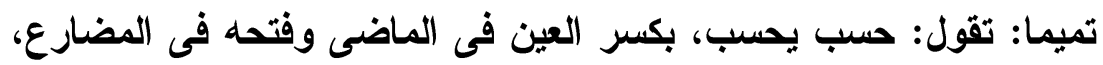

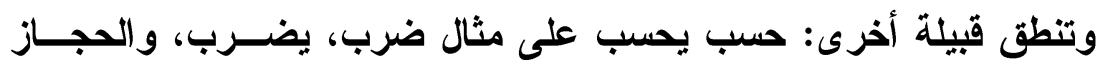

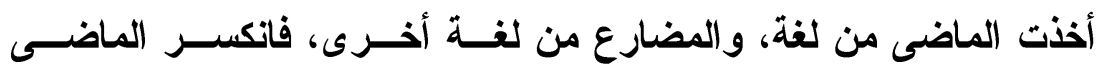

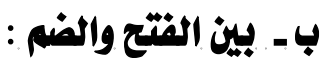

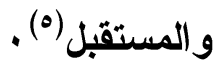

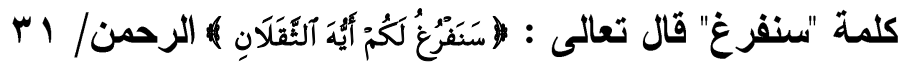

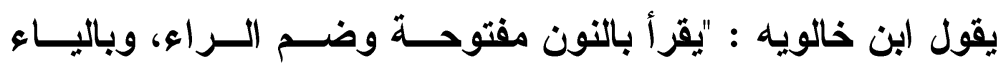

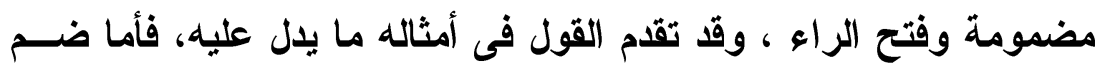

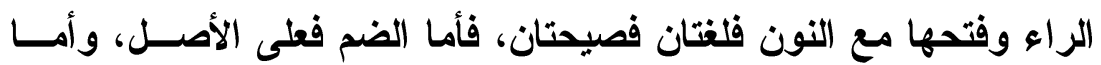

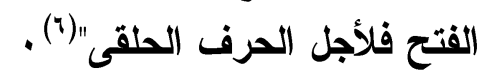

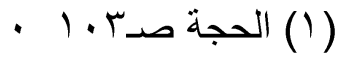

$$
\begin{aligned}
& \text {. } 170 \text { (Y) الإتحاف } 17 \text { (Y) }
\end{aligned}
$$

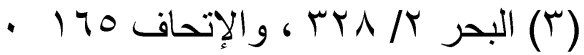

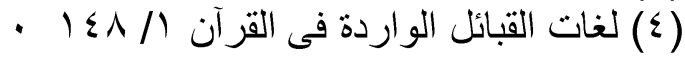

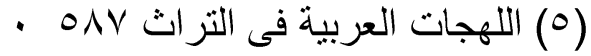

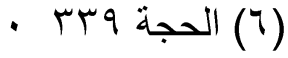


واللأن قر عا بفتح الراء ميع النون لاسنفرغ) هما: الأعرج، وقتادة(1)

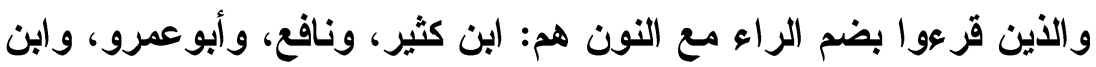

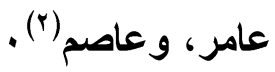
و"فرغ: من الثغل "فروغا" من باب قعد، و"فرغ يفرغ" من باب تعب

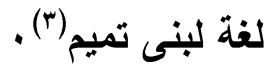

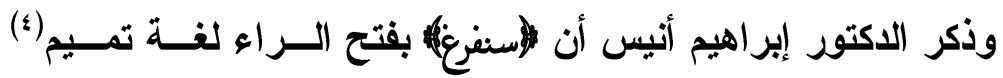
وجاء فى المعجم الكامل فى لهجات الفصحى أن فرغ يفرغ من بـ باب فــرح

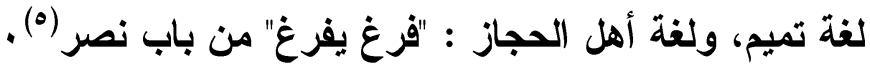

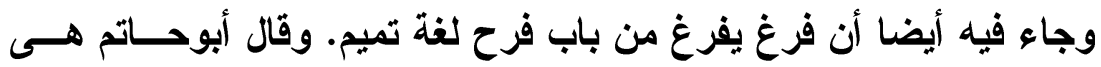

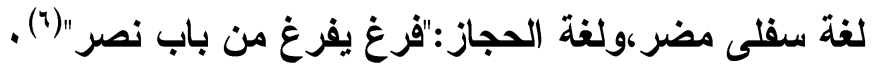

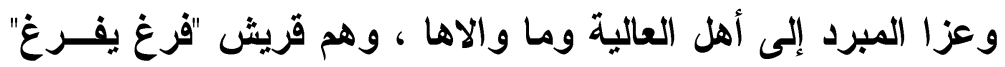
بفتح الراء فى الماضى، وضمها فى المضارع(v) .

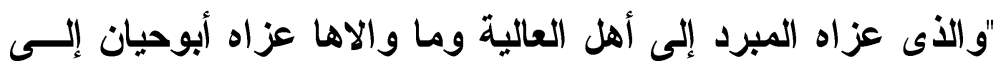

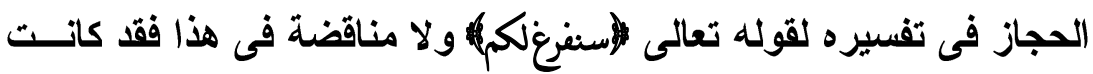

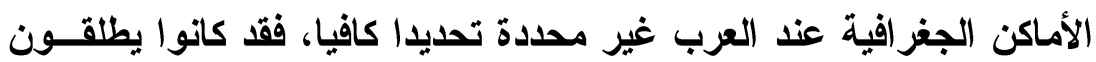

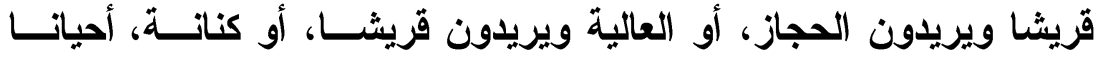

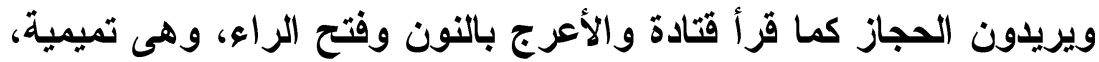

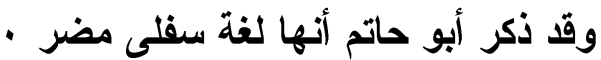

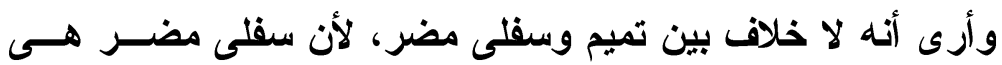

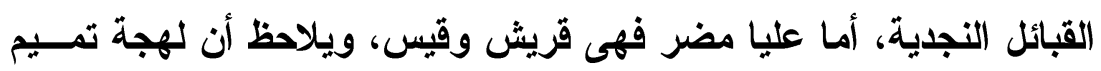

$$
\begin{aligned}
& \text { (1) مختصر في شواذ القرآن صد. } 10 . \\
& \text { - }
\end{aligned}
$$

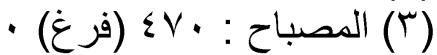

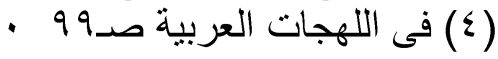

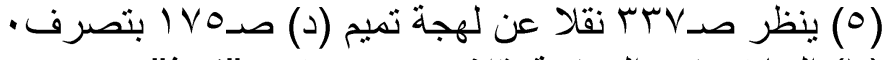

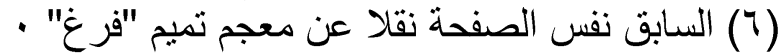

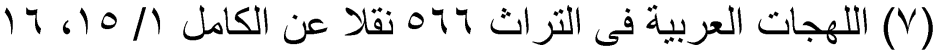




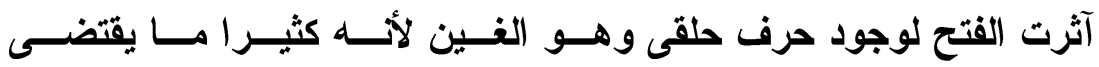

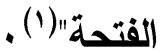

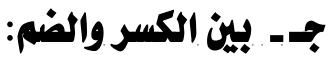

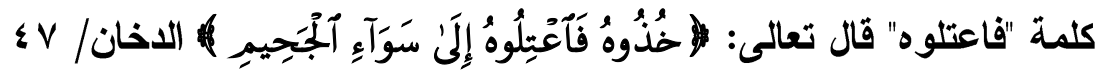

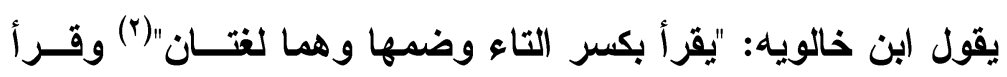

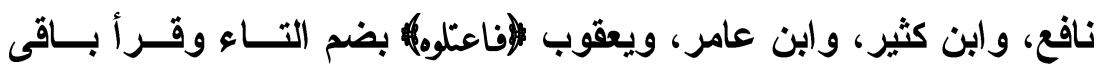

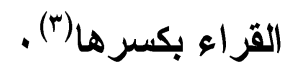

قال الأزهرى: هما لغتان فصيحتان معناه خذوه فاقصفوه كما يقصف الحطب (4)، وذكر مكى أنهما لغتان (o). كما جاء في إبراز المعانى أن الضم والكسر فى تاءع "فاعتلوه" لغتان وهو القود بعنف (").

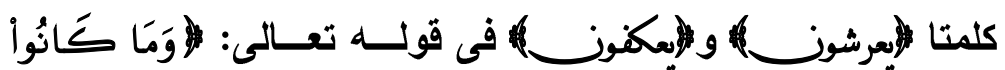

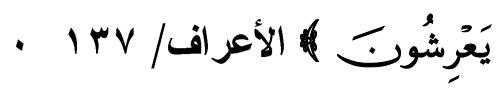

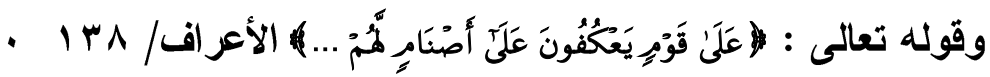

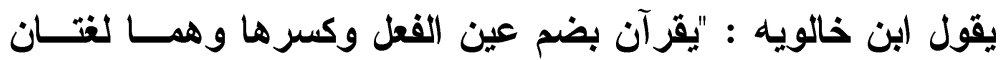

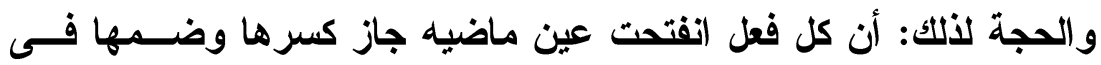

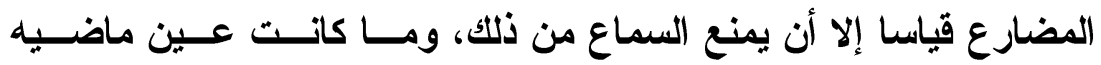

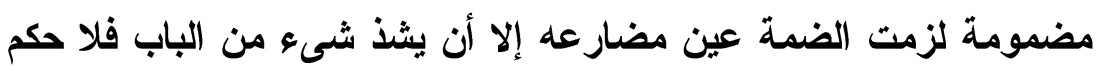

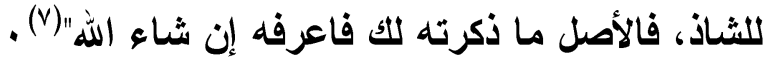

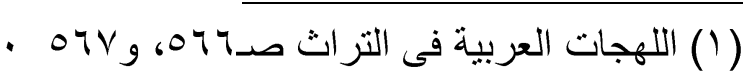

$$
\begin{aligned}
& \text { - }
\end{aligned}
$$

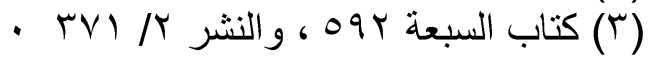

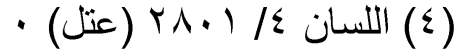

$$
\begin{aligned}
& \text { - }
\end{aligned}
$$

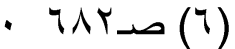

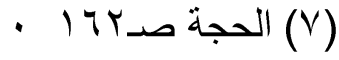


قرأ ابن كثير، ونافع، وأبوعمرو، وحمزة، و الكسائى وحفـص عـن فئن

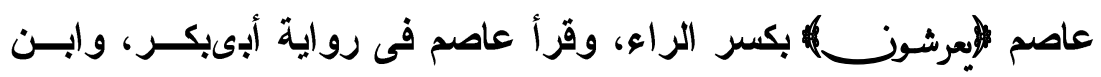
عامر: بضم الراء(1).

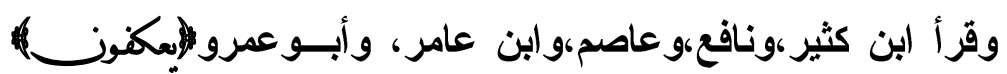

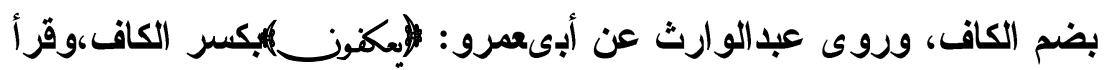

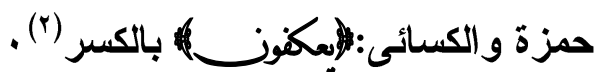

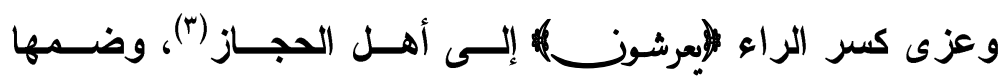

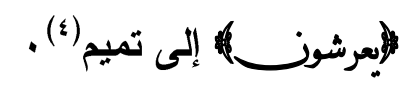

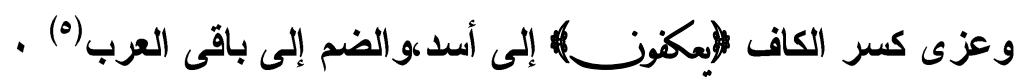

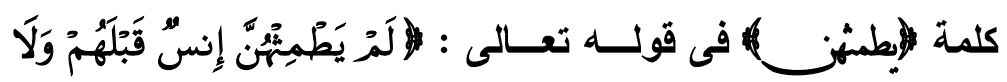

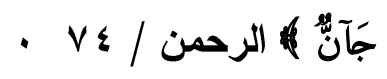

يقول ابن خالويه : "يقرأ بضم الميم وكسرها، وهما لغتان معناهمسـا:

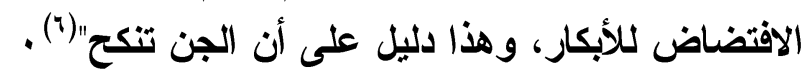

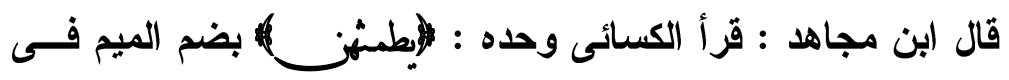

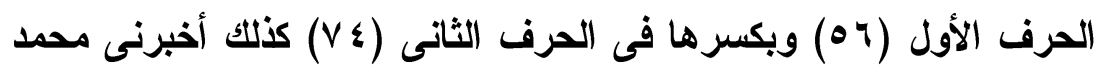

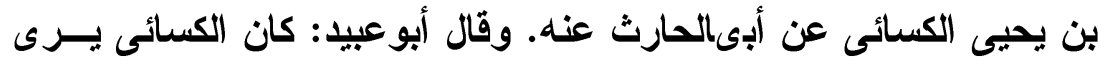

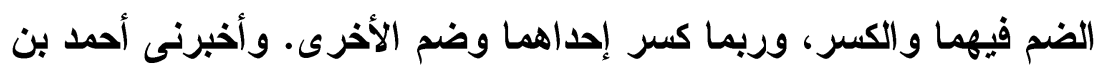

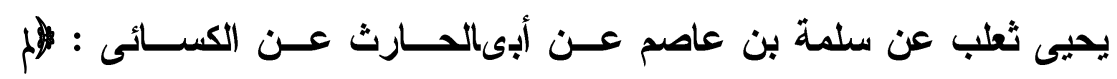

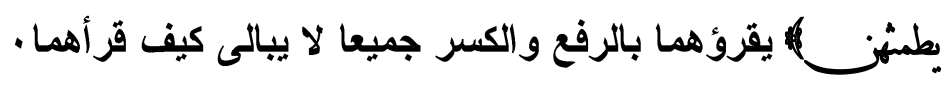

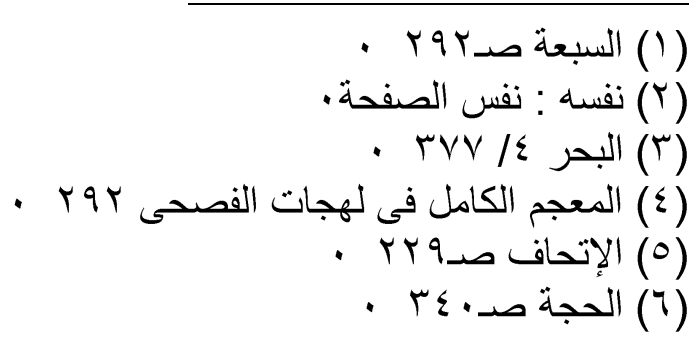




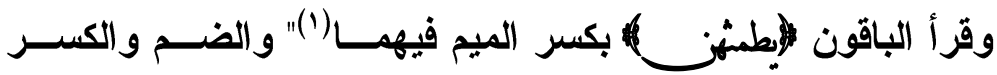

لغتان فى مضارع طمث كلمز (ץ) .

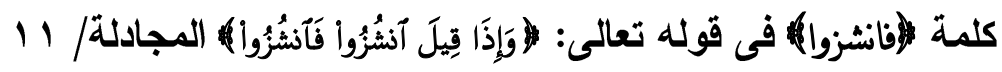

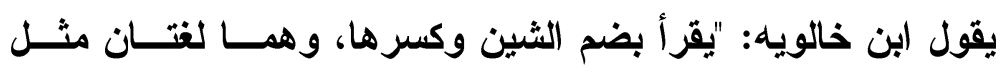

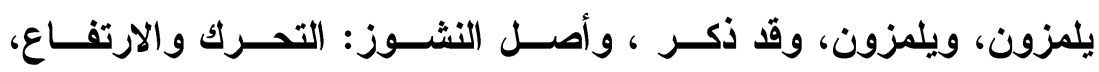

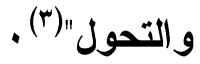

"قرأ المدنيان، وابن عامر، وعاصم، إلا أبا حــدون: إوإذا قيل اششزوا

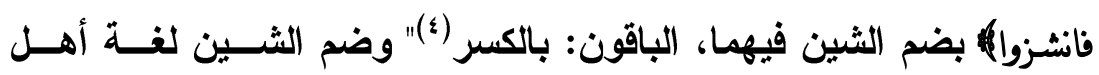

$$
\begin{aligned}
& \text { الحجاز ، والكسر لغة غيرهم (ه) . }
\end{aligned}
$$

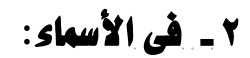

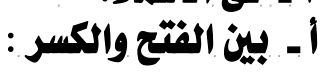

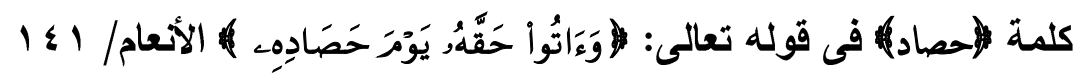

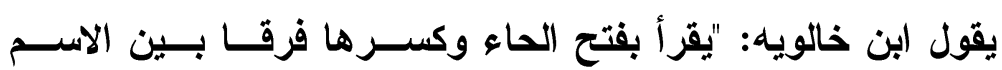
و المصدر على ما قدمنا القول فيه، أو على أنهما لغتان"(") .

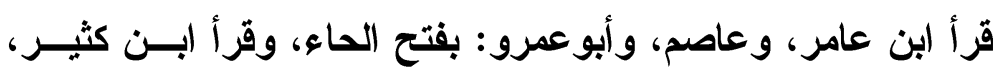

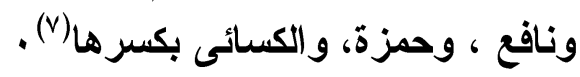

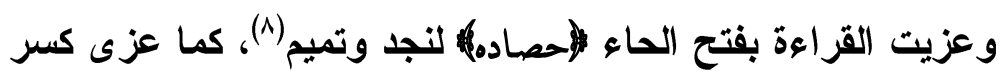

الحاء (أحصاده) لأهل الحجاز (9) .

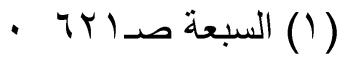

$$
\begin{aligned}
& \text { • }
\end{aligned}
$$

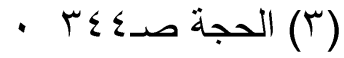

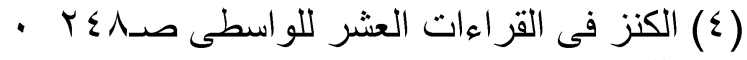

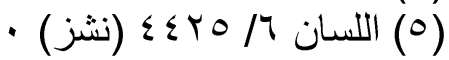

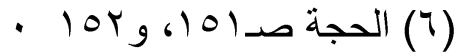

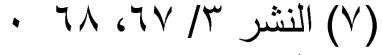

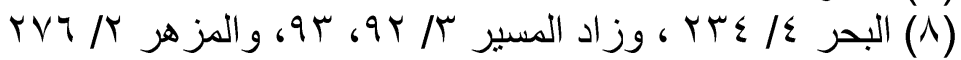

$$
\begin{aligned}
& \text { (9) نفس المصادر السابقة : ونفس الصفحات. }
\end{aligned}
$$


ويلاحظ أن القراعة بفتح الحاء قد عزيت لنجد وتميم، ولا غرابة فى في

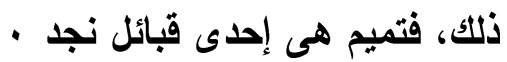

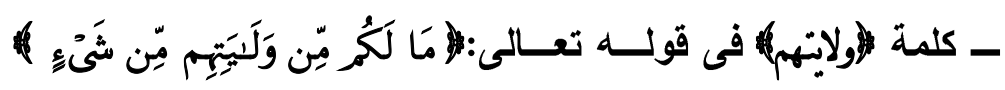
- vr/الأنفال

يقول ابن خالويه:"يقرأ بفتح الواو وكسرها هاهنا، وفى الكهف(1) .

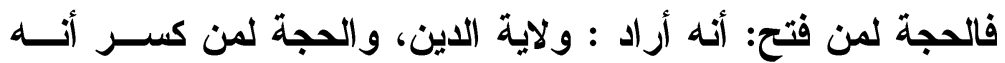

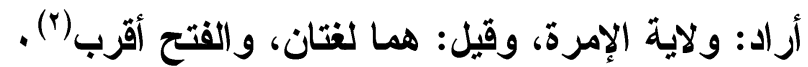

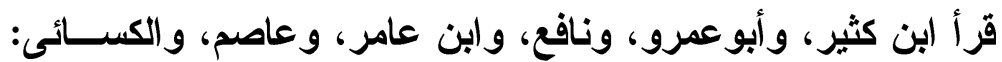

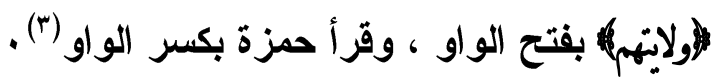

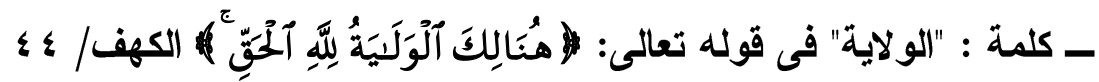

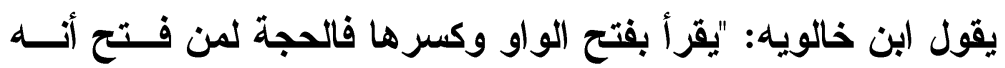

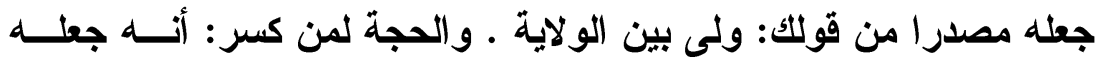

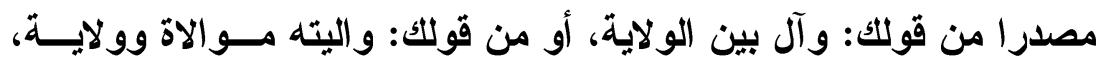

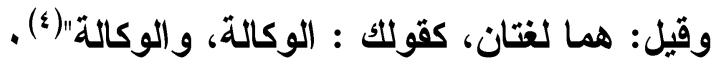

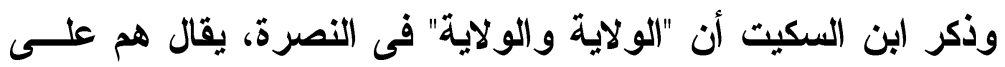

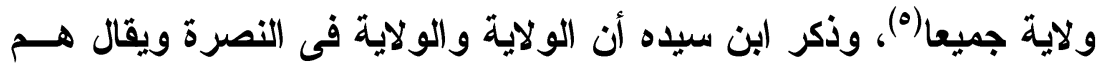

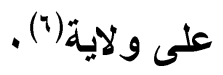

وقال اليزيدى: "أهل الحجاز : الولاية فى الدين ، والتــــلى مفتــوح،

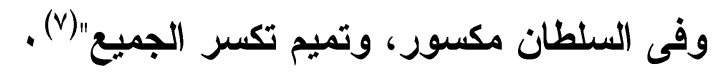

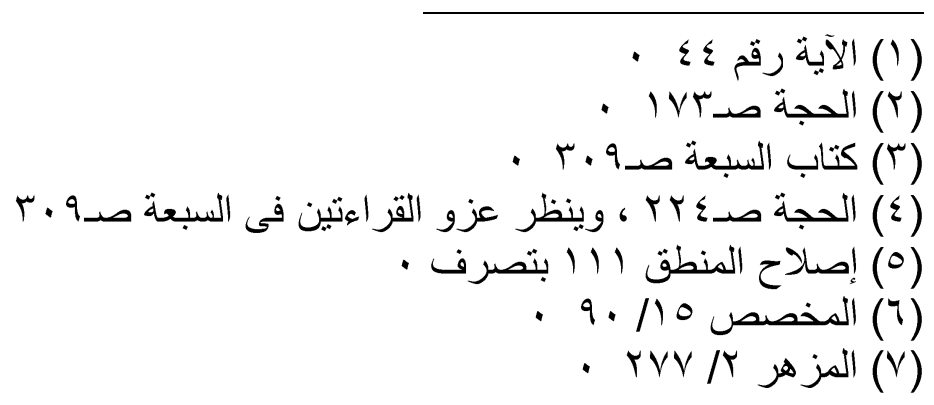




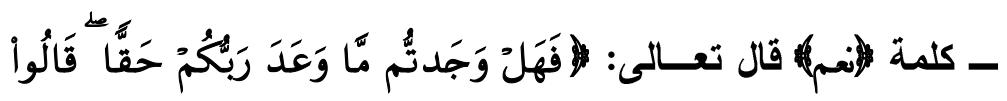

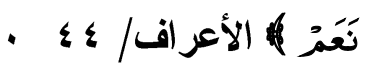

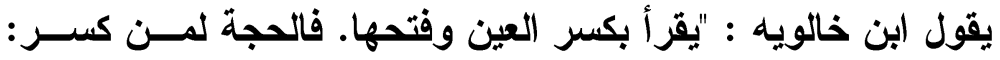

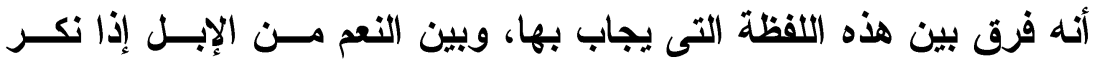

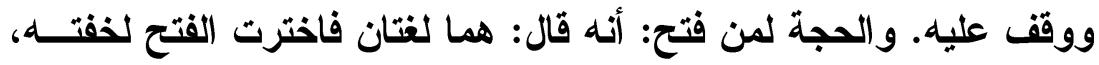
ولم ألتفت إلى مو افقة اللفظ.

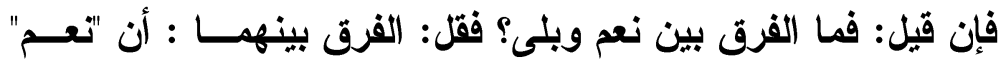

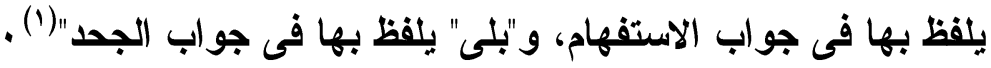

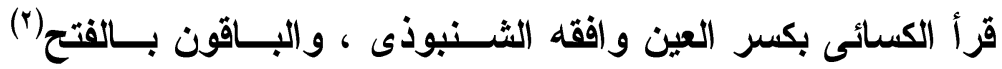

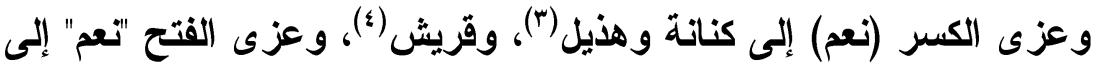

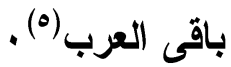

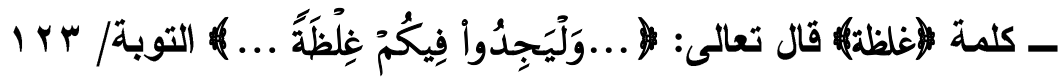
يقول ابن خالويه: "يقرأ بكسر الغين وفتحها، وهما لغتان، والكسـر

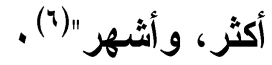

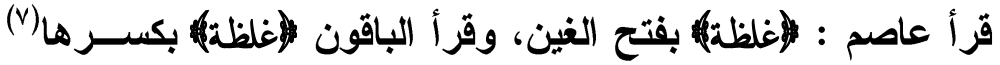
وعزى كسر الغين لبنى أسد، وفتحها لأهل الحجاز (^) .

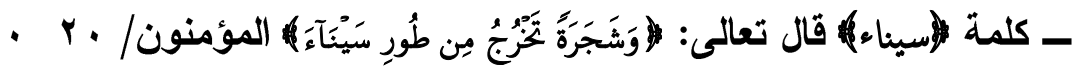

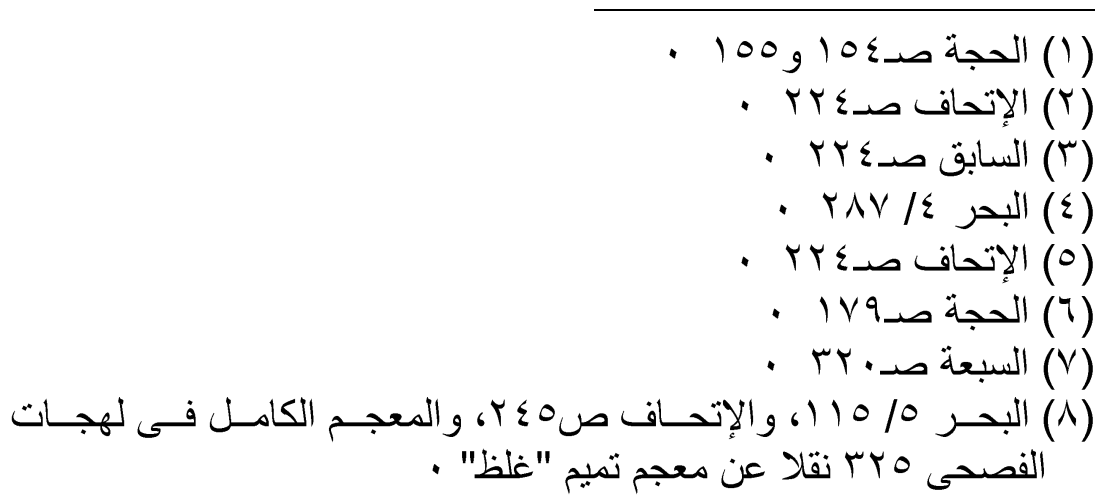


يقول ابن خالويـه : "يقرأ بكسر السين وفتحها، وهما لغتان وأصــله

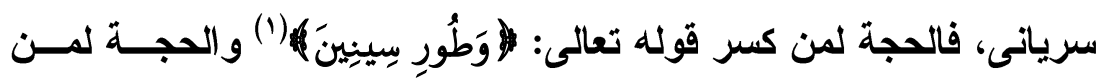

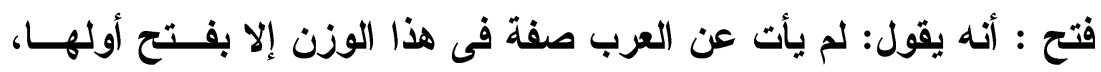
كقولهم : (حمراء) و(صفراء) فمملته على الأشهر من ألفاظهم، ومعنــاه:

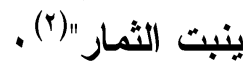

قرأ (بن كثير، ونافع، وأبوعمرو: (بطورسيناء) مكسورة السين، وقرأ

عاصم، وابن عامر، وحمزة، والكسائى مفتوحة السين(") .

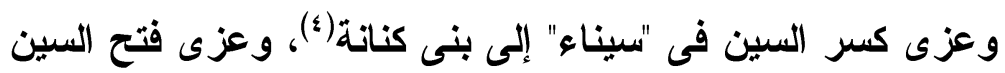

فى "سينين" إلى التميميين و البكريين (ه) .

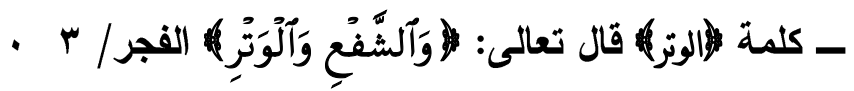

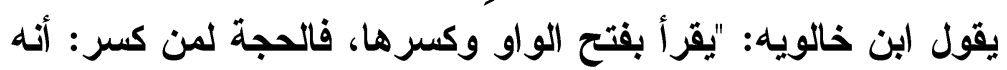

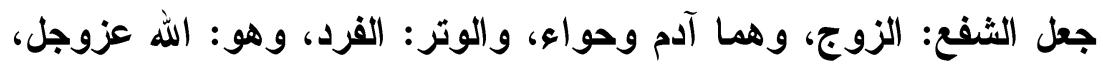

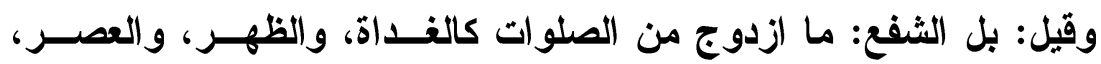

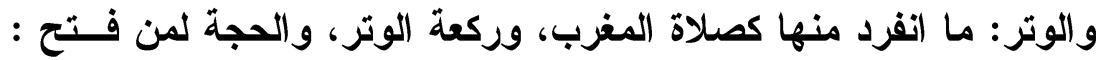

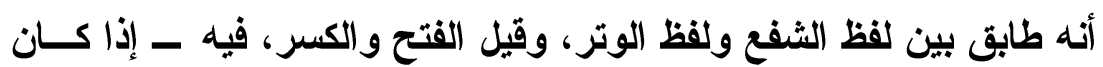

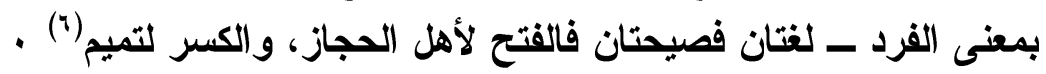

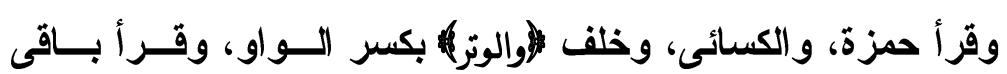

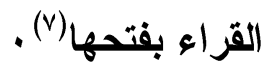

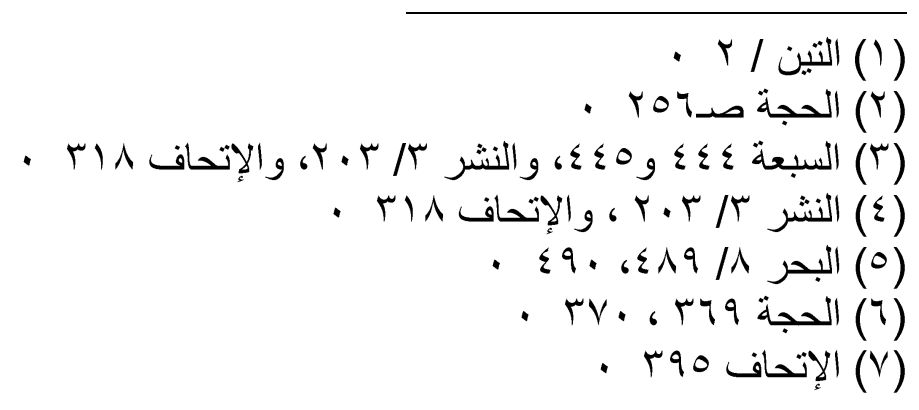


وعزا الفراء الكسر لتميم وأسد، والقتح لأهل الحجاز (1)، وعزا البناء

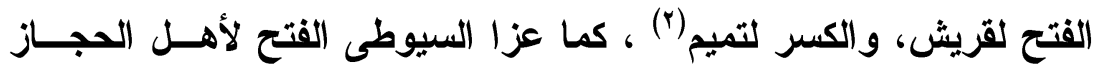
و الكسر لتميم (r) .

ومما سبق يتضح لنا أن الفتح عزى للحجاز ولقريش ولا غرابة فى إئ

ذلك، فقريش إحدى قبائل الحجاز (๕) . وكذلك عزى الكسر لتميم وأسد ولا غرابة فى ذلتك أيضا فهما مسن فئن

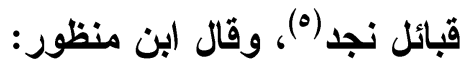

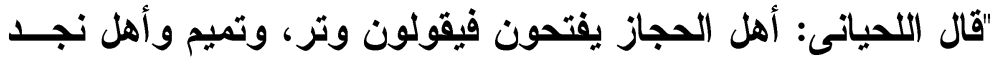

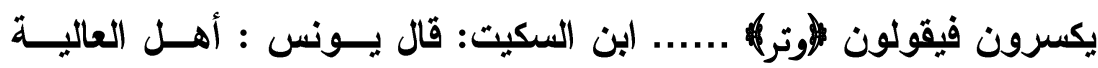
يقولون: الوتر فى العدد والوتر فى الأحل، قال: وتميم تقول وتر ، بالكسر

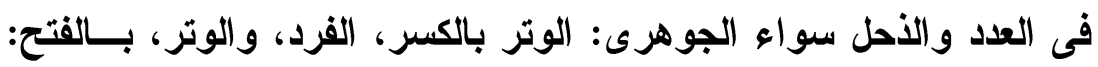

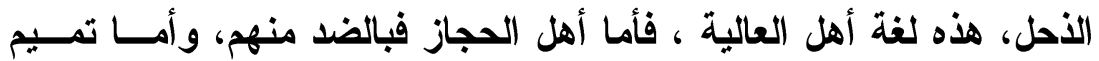

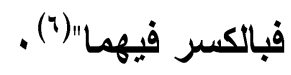

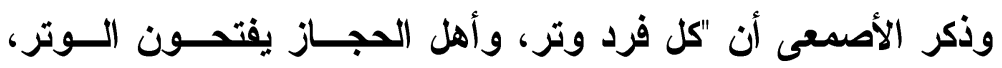

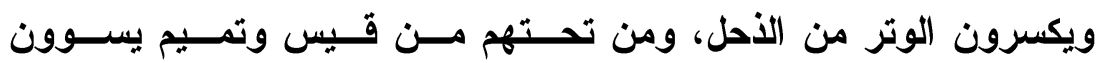

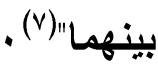

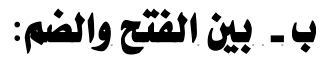

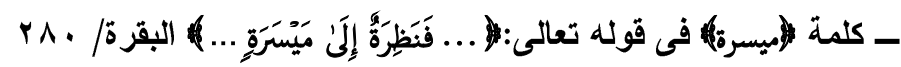

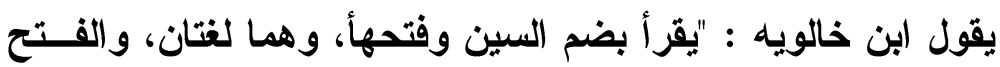

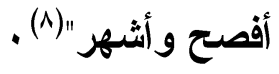

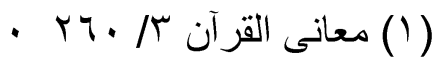

$$
\begin{aligned}
& \text { - (Y) الإتحاف }
\end{aligned}
$$

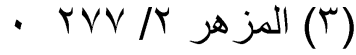

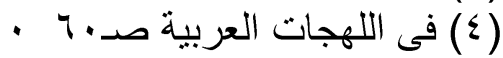

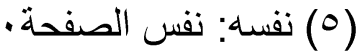

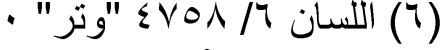

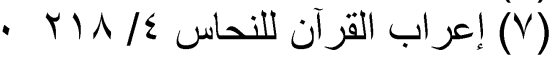

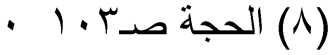


وقرأ نافع ماميسرة) بضم السبن، وقرأ البــاقون بفتحهــا(1)، وعـزا

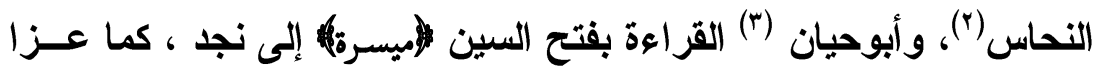

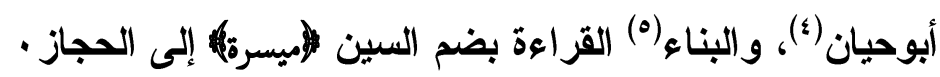

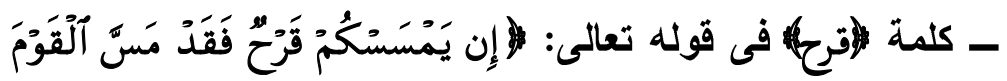

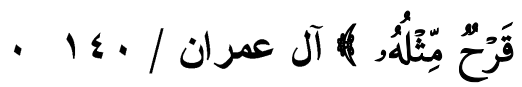
يقول ابن خالويه: يقرأ بفتح القاف، وضمها، فالحجة لمن فتح أنسـه:

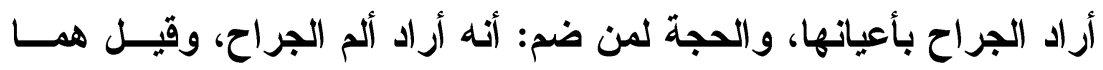

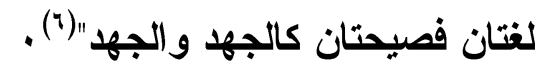

وقرأ (بن كثير، وأبوعمرو، وابن عامر، ونافع: (القرح) بقتح القاف وقــرأ

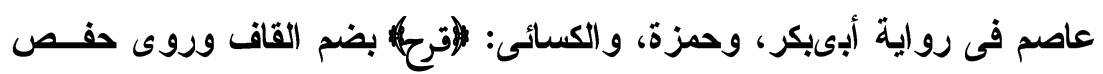

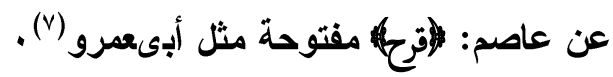

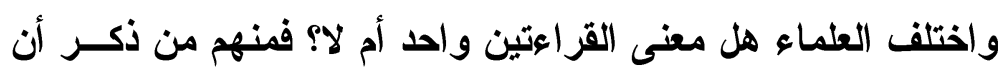

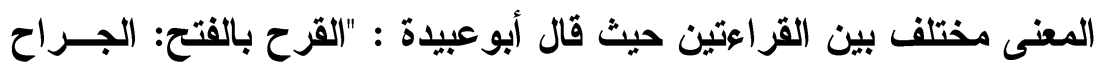
والقتل، والقرح بالضم: ألم الجراح"(^) .

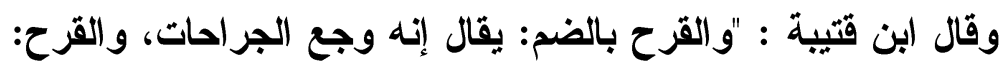

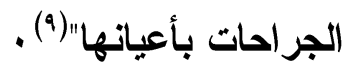

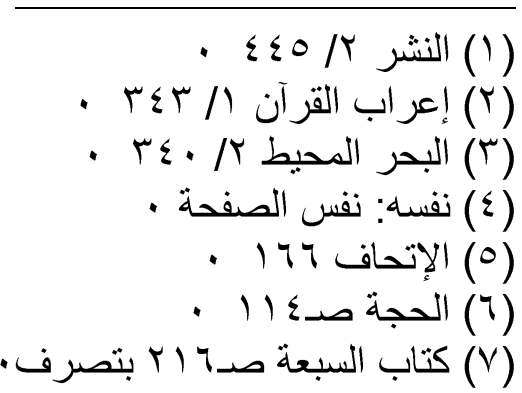

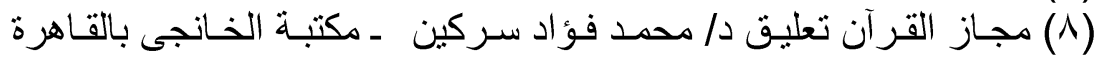
$1 \cdot \varepsilon / 1$

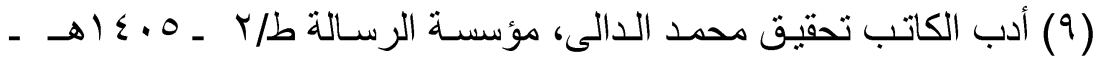


وقال ابن منظور : "وقيل هو بالضم الاسم، وبالفتح المصدر"(1) .

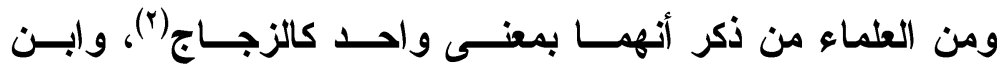

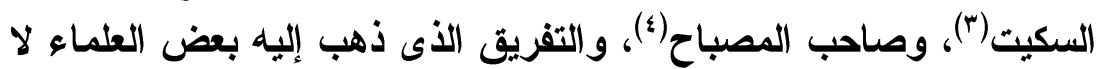

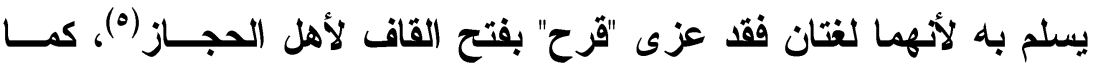
عزى "قرح" بضم القاف إلى تميم(") .

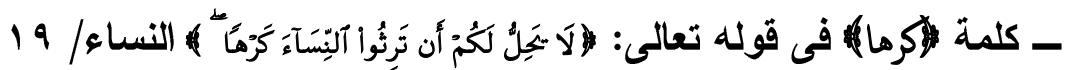

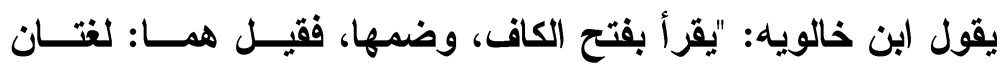

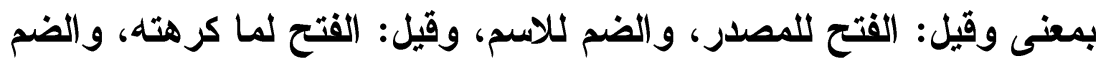

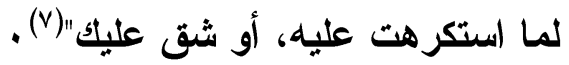
وقرأ ابن كثير، ونافع، وأبوعمرو، وعاصم وابـن عـامر: (كرما) بفتح الكاف، وقرأ حمزة و الكسائى: (كرها) بضم الكاف(^) .

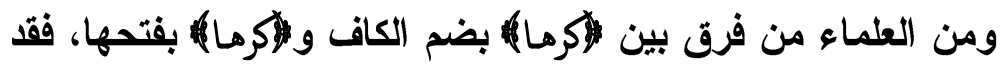
ذكر الفراء أن الكره ما أكرهت نفسك عليه، والكره ما أكرهك غيرك عليــهـ

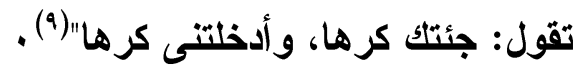

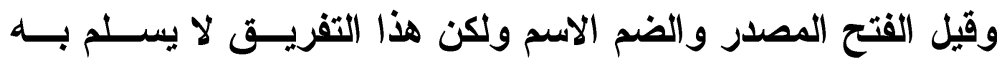

· لأنهما لغتان

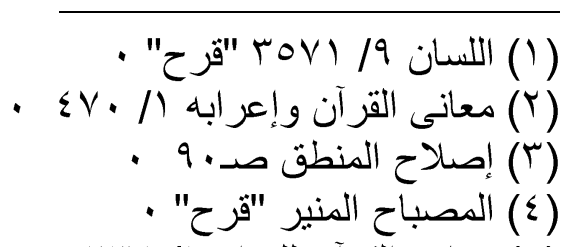

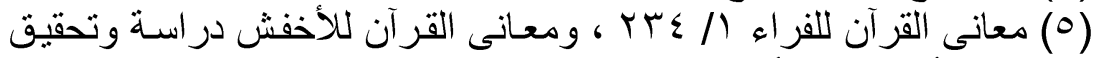

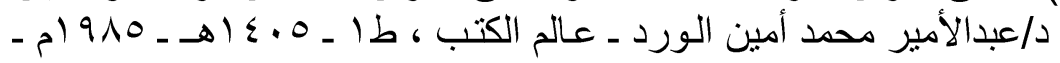

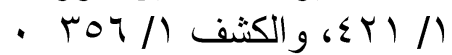

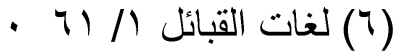

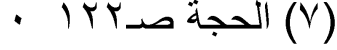

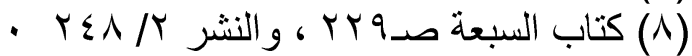

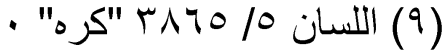


قال النحاس : "والحجة فى هذا قول من يعرف ويعتد به أن "الكــره

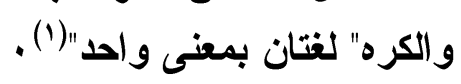

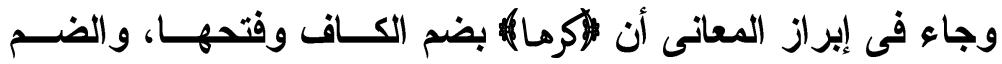

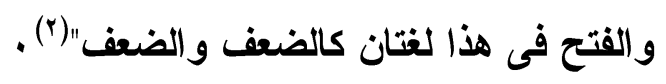

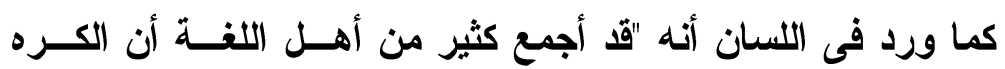

$$
\text { و الكره لغتان" (r) . }
$$

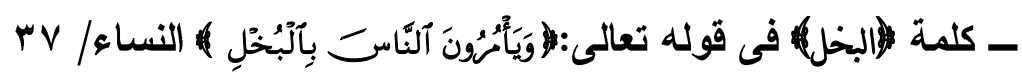

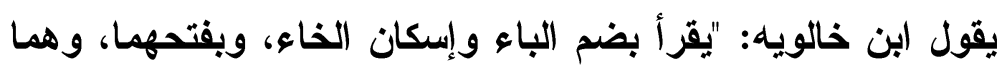

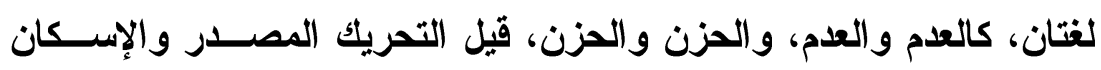

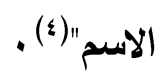

قرأ حمزة، و الكسائى ، وخلف (والبخل) بفتح الباء و الخاء، وقرأ باقى القراء بضم الباء وسكون الخاء(ه) .

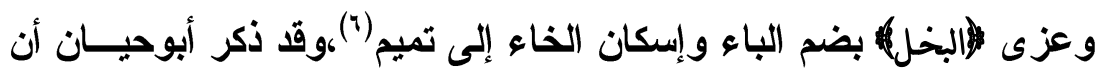

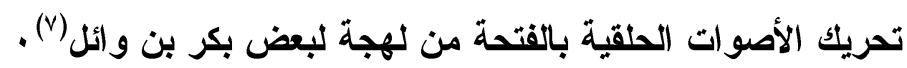

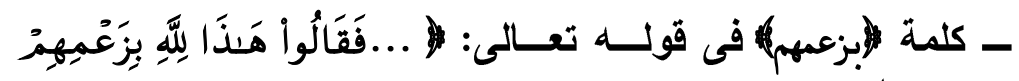

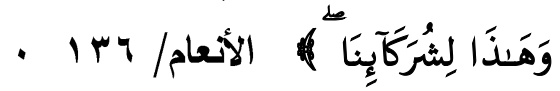

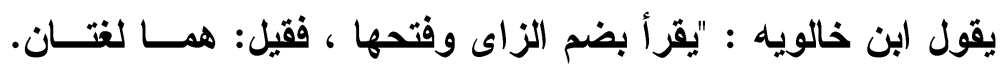

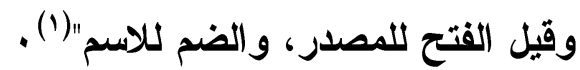

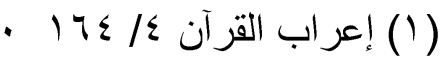

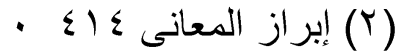

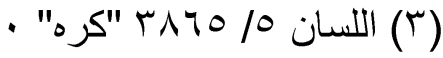

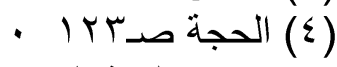

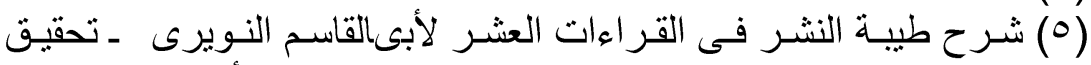

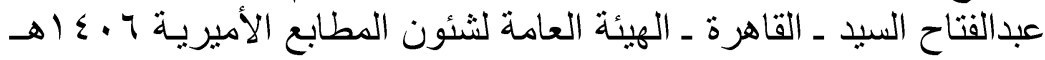

$$
\text { - r. T/ع: }
$$

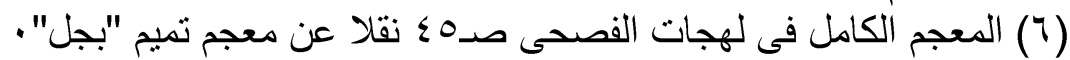

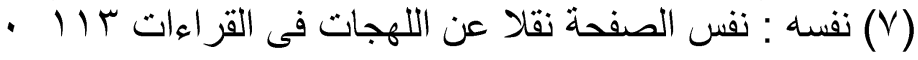


وقر أ الكسائى وحده : (لبزعمهم) مضمومة الــزاى، وقــرأ البـاقون:

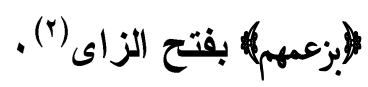

وعزى "الزعم" بفتح الزاى للحجاز، كما عزى "الزعم" بضم الــزاى

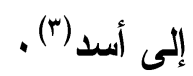

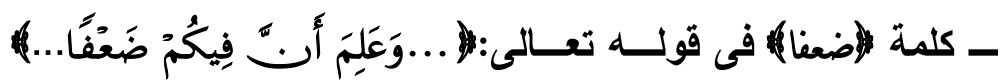

الأنفال/ 79

يقول : "يقر أ بضم الضاد وفتحها، وهما لغتان"(๕) وقر أ ابــن كثيـر ،

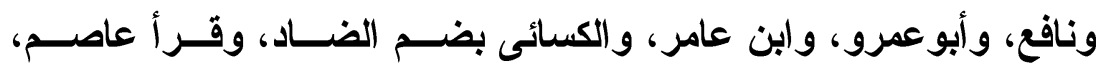

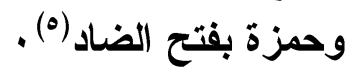

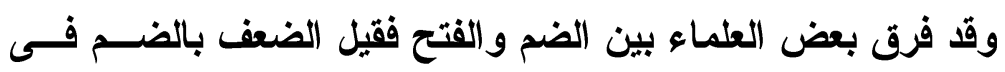

الجسد، و"الضعف" بالفتح فى الرأى و العقل (†) .

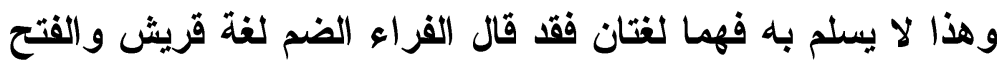

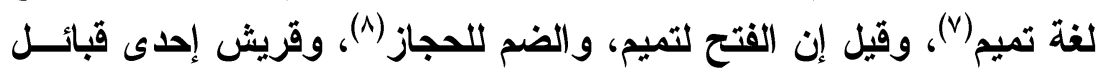
الحجاز •

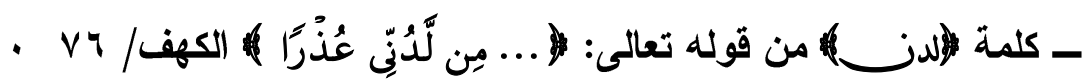

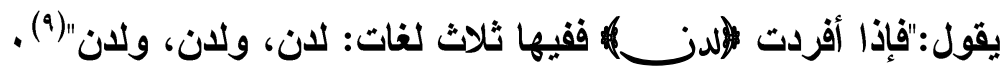

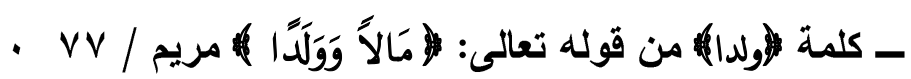

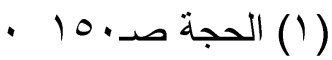

$$
\begin{aligned}
& \text { - }
\end{aligned}
$$

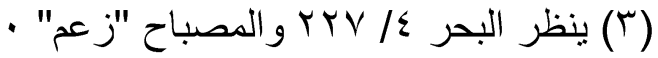

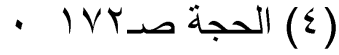

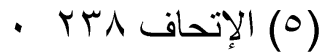

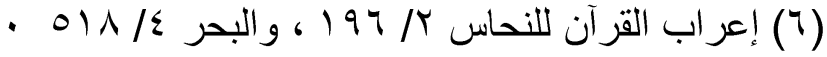

$$
\begin{aligned}
& \text { - jov (V) }
\end{aligned}
$$

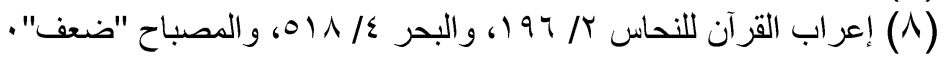

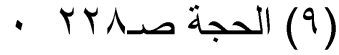


يقول ابن خالويه: "يقرأ بفتح الواو و اللام، وبضم الــواو وإســكان

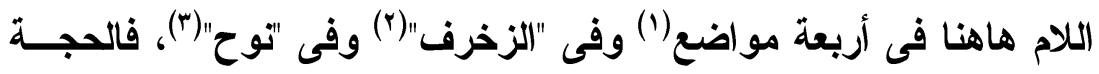

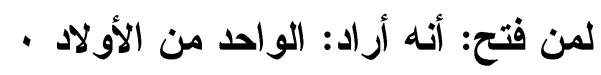

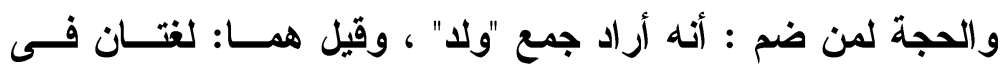

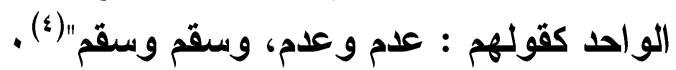

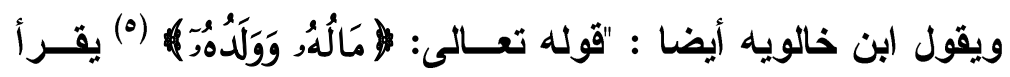

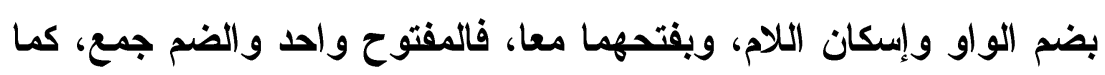

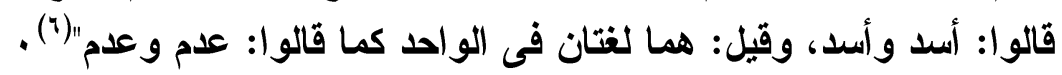

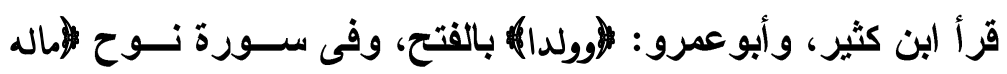

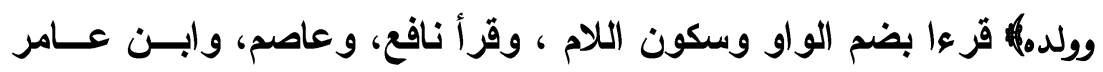

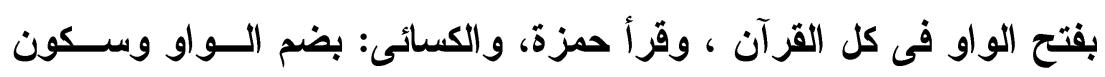

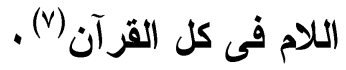

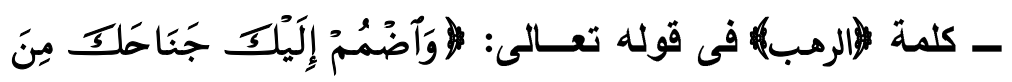

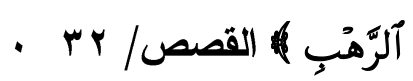

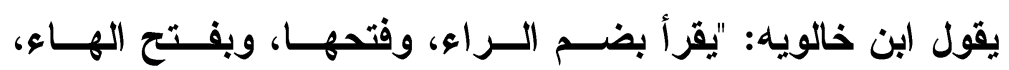

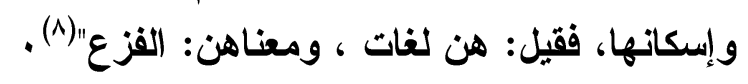

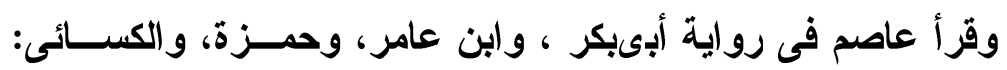

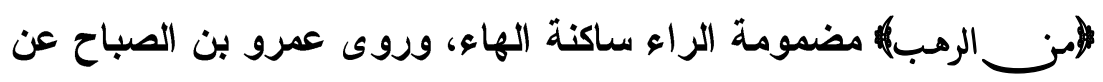

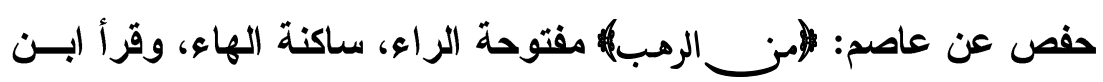

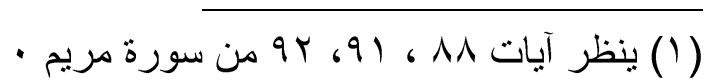

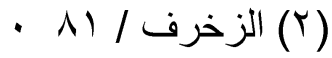

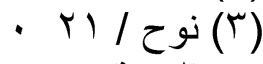

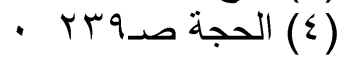

$$
\begin{aligned}
& \text { - } r \text { / / (3) }
\end{aligned}
$$

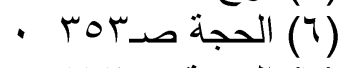

$$
\begin{aligned}
& \text { - السبعة صد (Y) } \\
& \text { - rVV الحجة }
\end{aligned}
$$




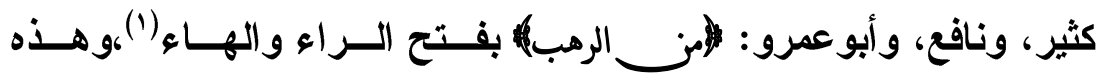

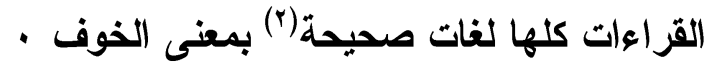

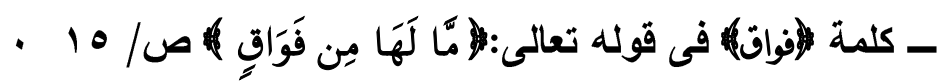

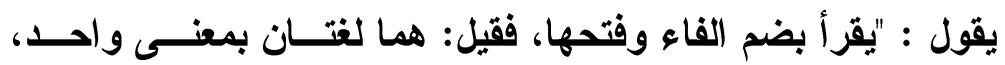

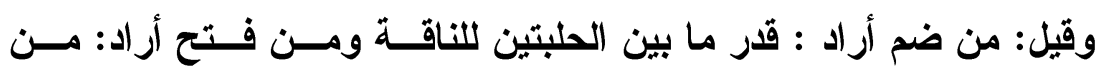

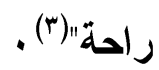

وقرأ حمزة،وخلف،والكسائى (افواق) بضم الفاء،وقرأ الباقون بقتحها(؛) .

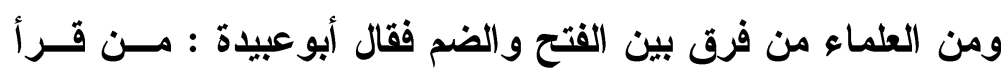

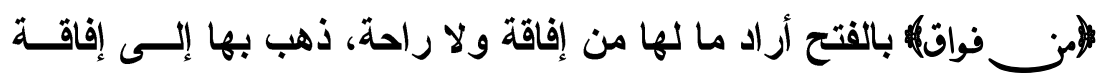

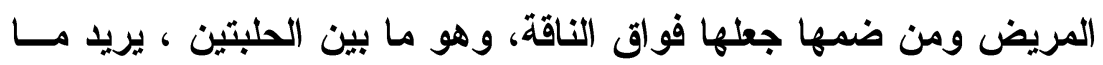
لها من انتظار"(0). و القول بالفرق بين الفتح والضم هنا غير مرضى، لأنهما لغتان منسوبتان،

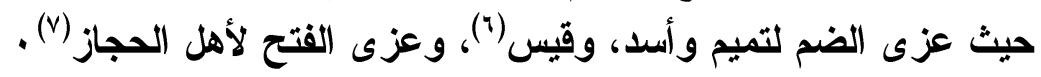

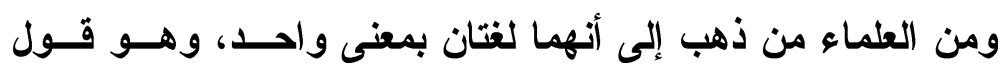

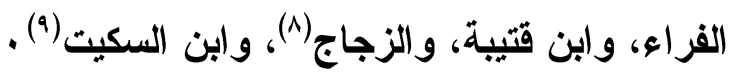

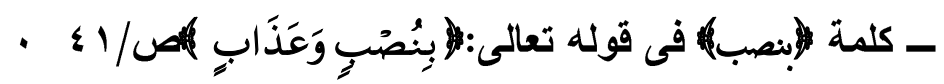

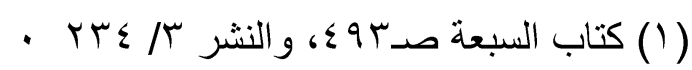

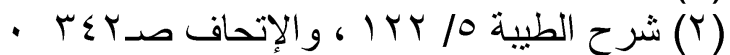

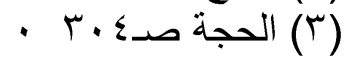

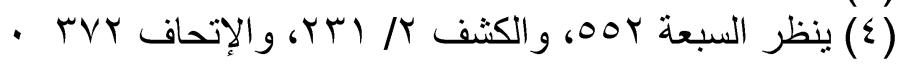

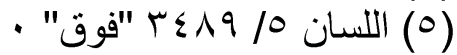

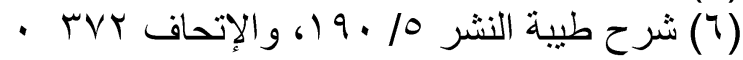

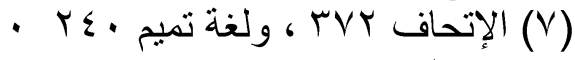

$$
\begin{aligned}
& \text { - زاد الإنسير (^) }
\end{aligned}
$$

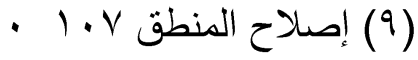




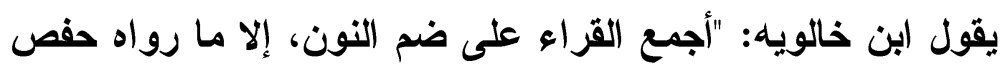

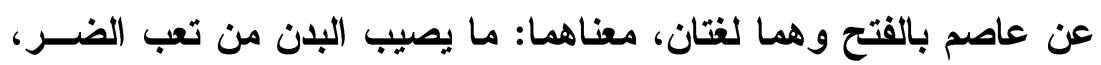

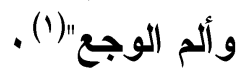

روى هبيرة عن حفص عن عاصم: (بنصب) منصوبة النون سـاكنة

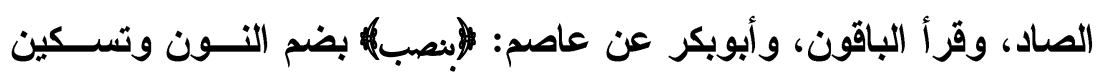

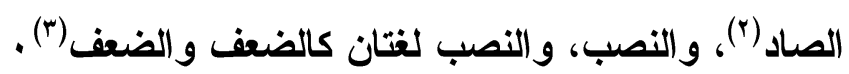

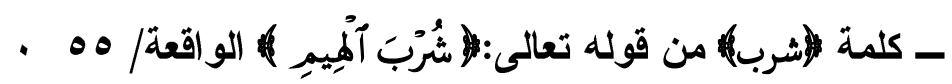

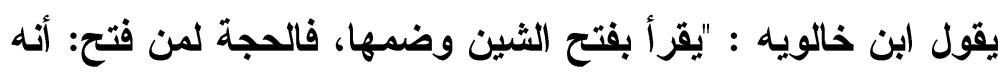

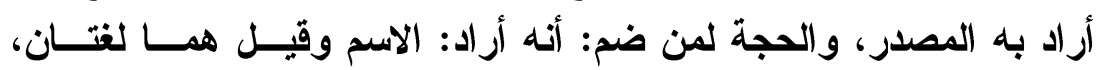

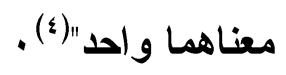

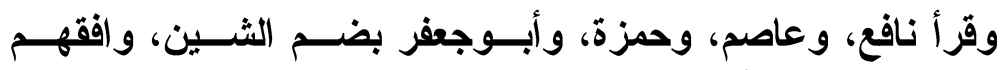
الحسن، والأعش، وقرأ الباقون بفتحها، وهما مصدر شرب، كالأكل، وقيل ولئ

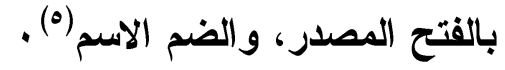
و التفريق بين الفتح والضم لا يسلم به لأنهما لغتان فقد ورد أن أهل

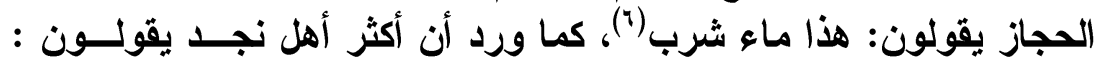

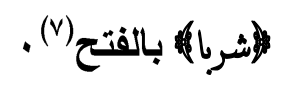

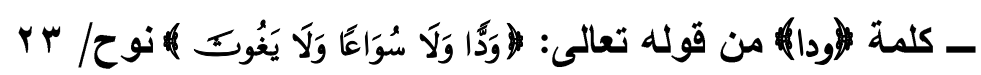

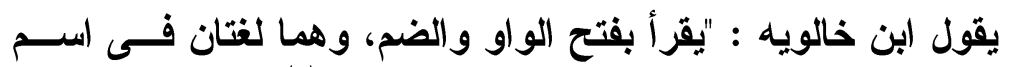

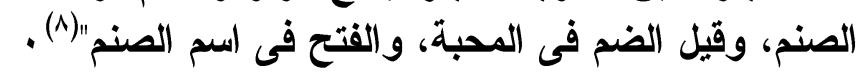

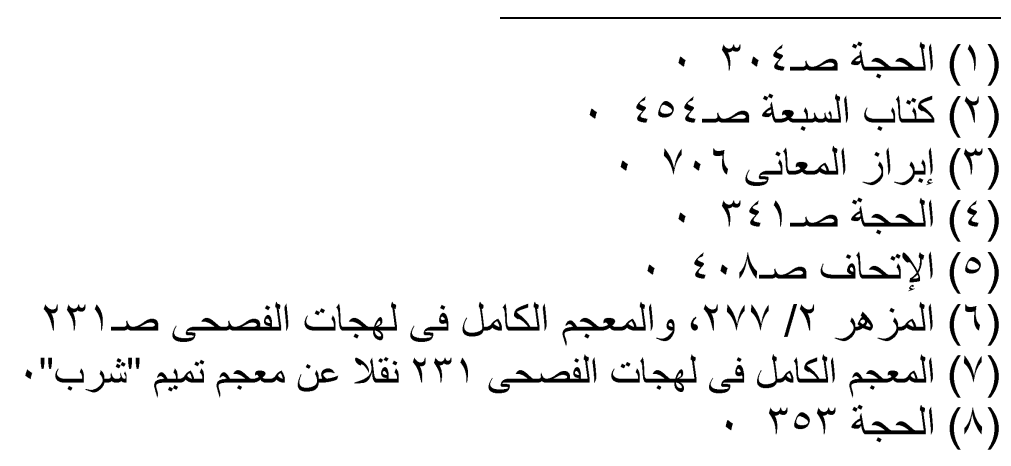


وروى أبو الربيع عن بريـــة عـن أبىبكـر عـن عاصـم : (وردا)

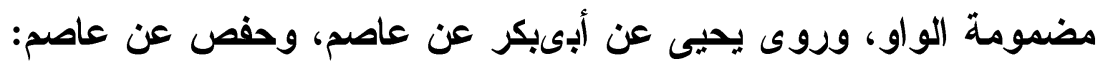

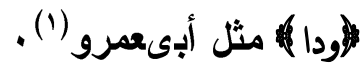

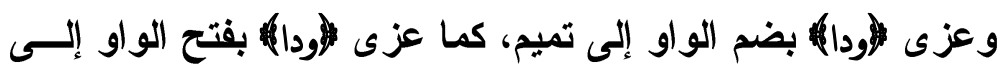

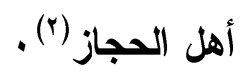

\section{جـ- بين الكسر والضم : (1ان}

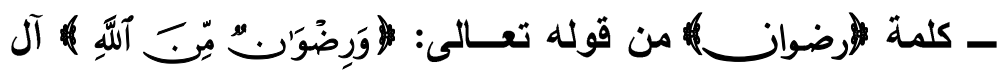

$$
\text { عمران/ } 10
$$

يقول ابن خالويه : "يقرأ بكسر الراء وضمها، فالحجة لمن كسرها:

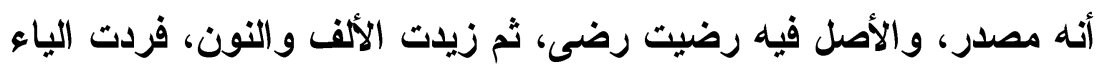

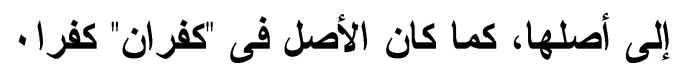

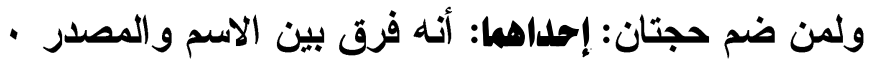

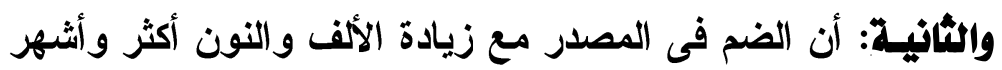

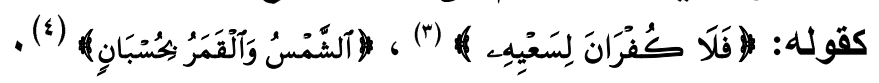

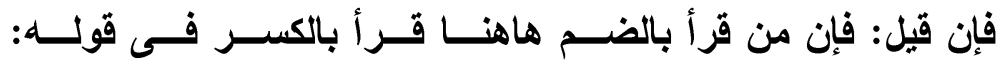

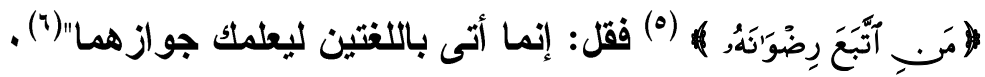

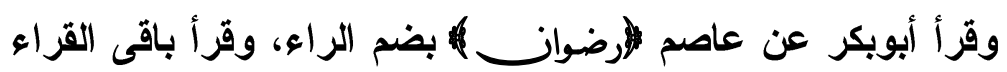

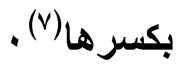

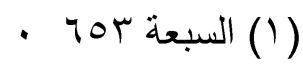

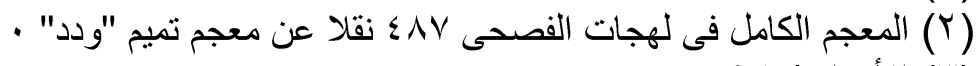

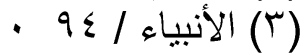

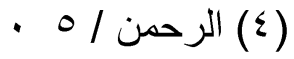

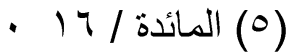

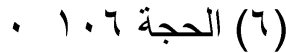

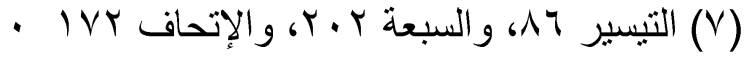




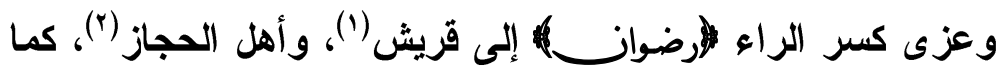

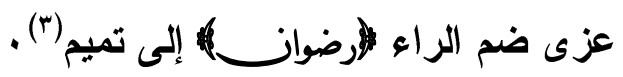

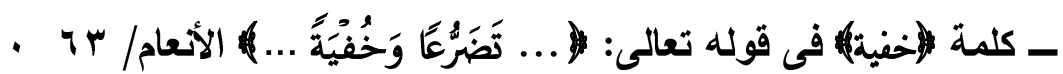

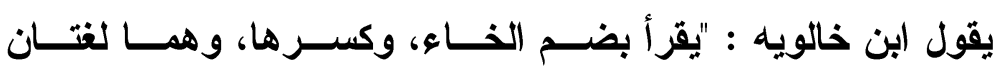

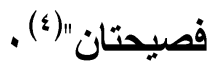

وقرأ أبويكر عن عاصم (لخفية) بكسر الخاء، وقرأ باقى القراء بضمها(ه).

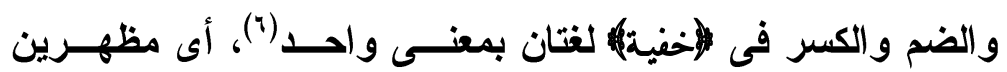

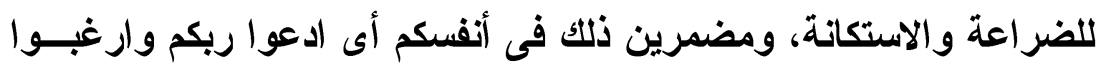

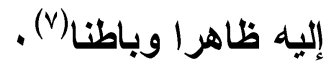

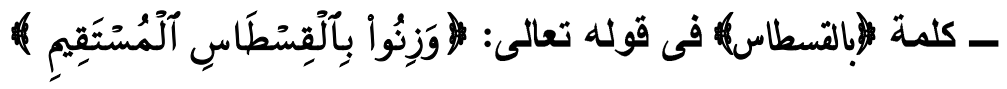
- الإسراء/ هر

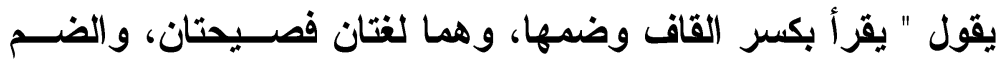

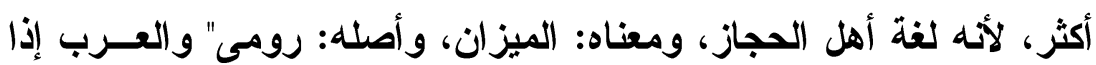

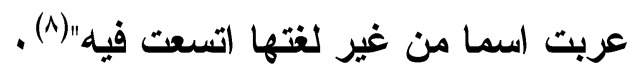
وقرأ حمزة، والكسائى، وحفص عن عند عاصم بكسر القـاف (لقسطاس) وقرأ (بن كثير، ونـافع، وأبوعمرو، وابن عــامر، وأبـويكر عـن عاصــم

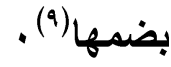
وعزى الضم (لاقسطاس) إلى أهل الحجاز، والكسر إلى غيرهم (1) .

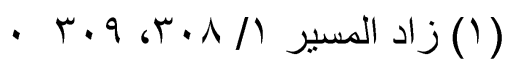

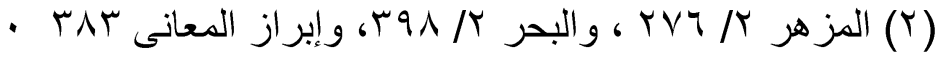

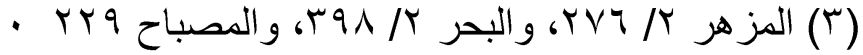




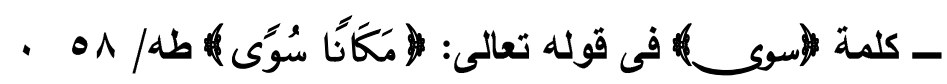

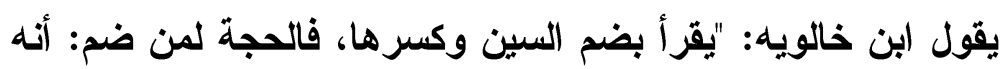

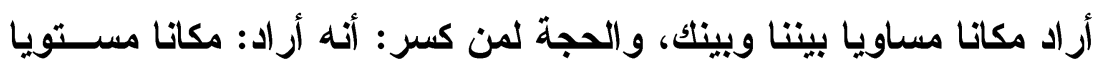

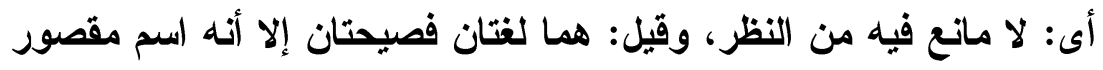

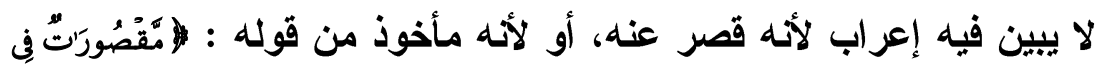

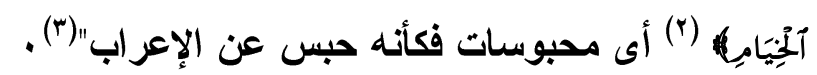

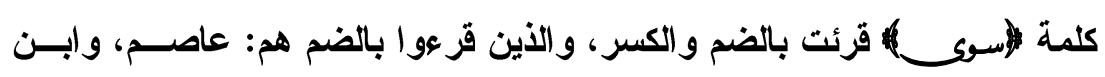
عامر، ويعقوب، وحمزة، وخلف، وقرأ باقى القراء بالكسر (4) .

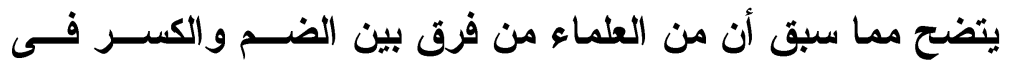

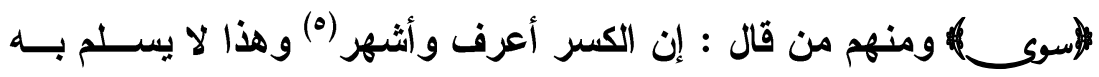

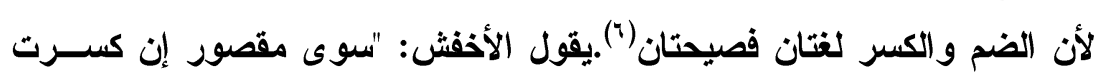

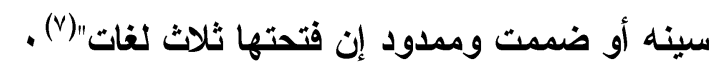

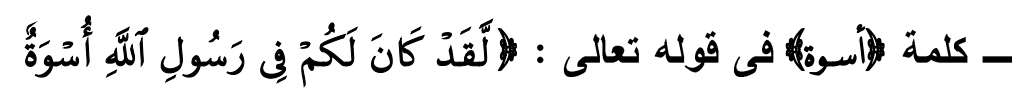

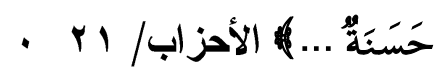
يقول : "يقرأ بكسر الهمزة وضمها، وهما لغتان كما قــالوا: رشــوة

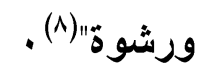
وقرأ عاصم (أسوة) بضم الألف حيث وقعت، وقرأ البـاقون: (لإسوة)

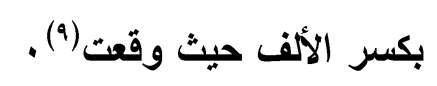

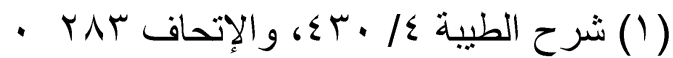

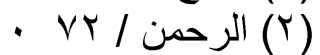

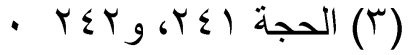

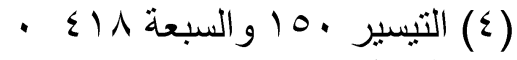

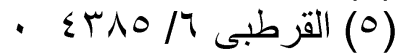

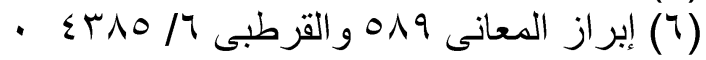

$$
\begin{aligned}
& \text { - البحر (1) (Y) }
\end{aligned}
$$

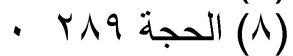

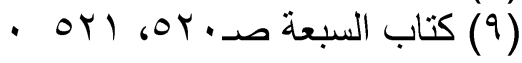




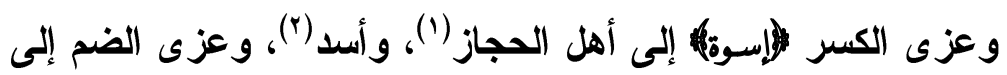

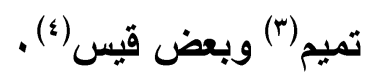

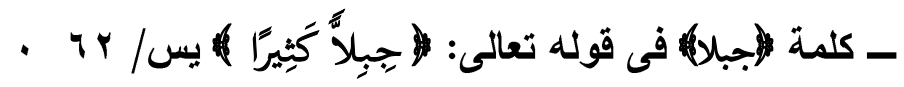

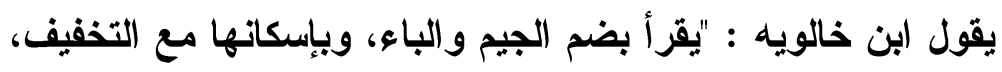

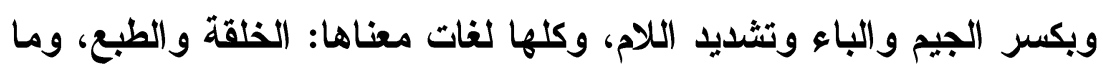

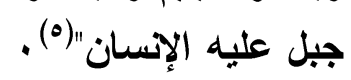

وقرأ نافع، وعاصم (لجبلاك) بكسر الجيم والباء مع تثديد التلام، وقرأ

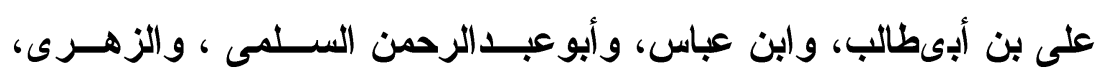

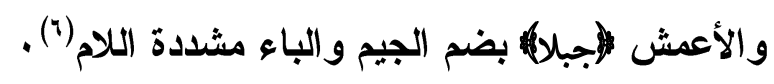

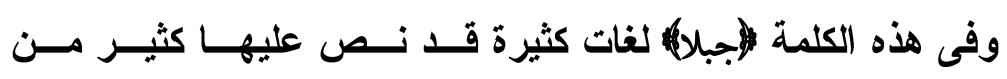

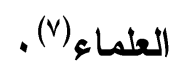

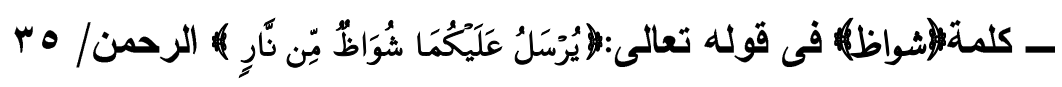

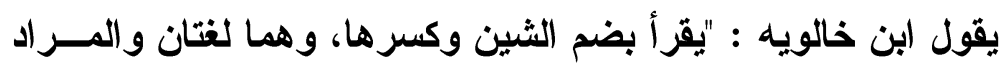
بهما: اللهب الذى لا دخان لهة"(A) .

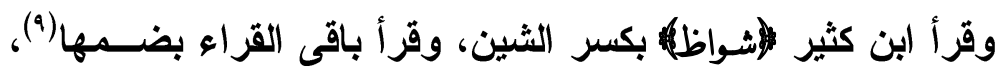
وعزى (الشواظ) بكسر الثبين إلى بذىكلاب(· (1).

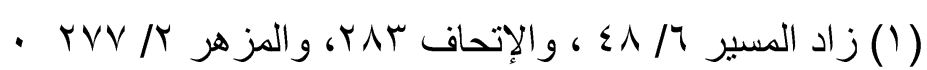
· الإن - r r - ( ) ( - ( ) (0)

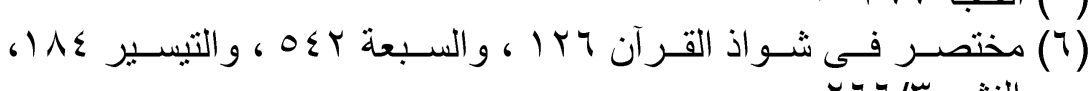

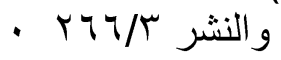

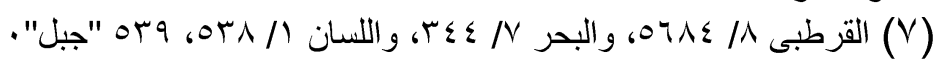

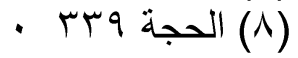

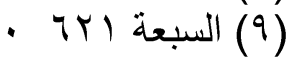

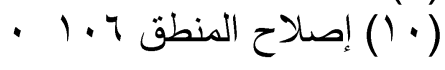




\section{دـ ــ بين الفتح والكسر والضم:}

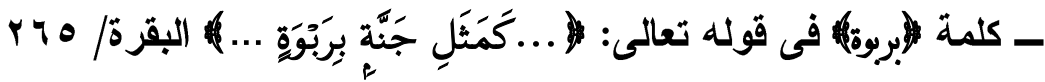
يقول ابن خالويه: قوله تعالى لمبربوة) هاهنا وفى المؤمنين (1) يقرآن

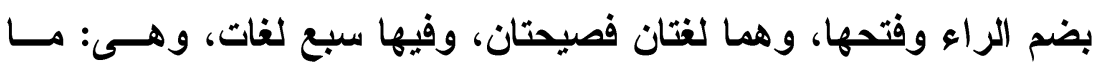

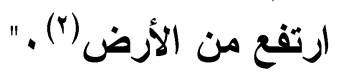

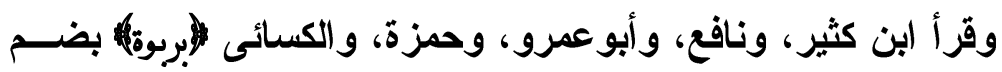

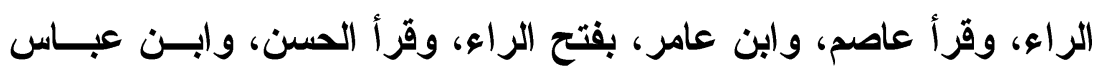

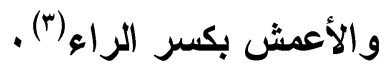

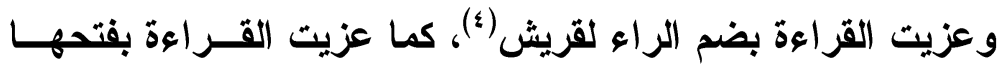
لتميم (0)

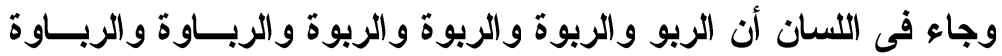

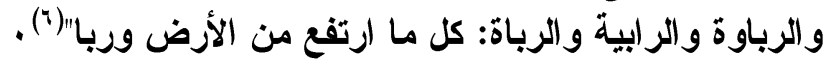

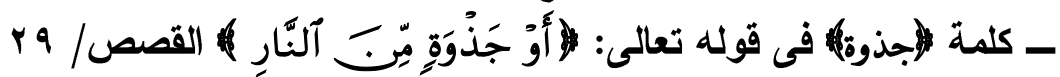

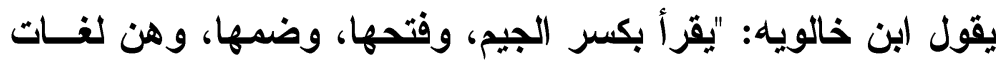

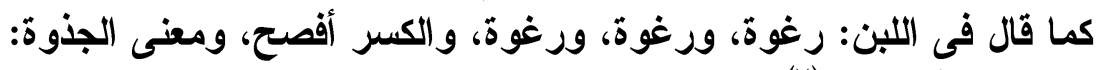

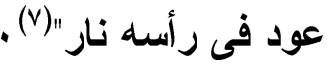

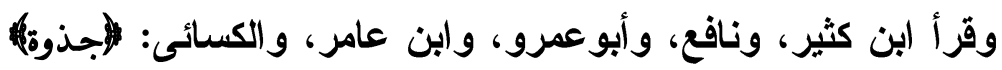

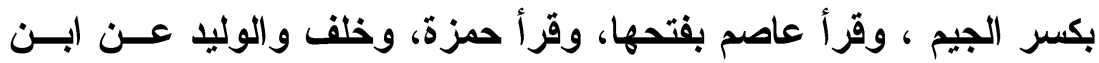

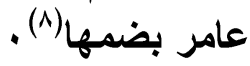

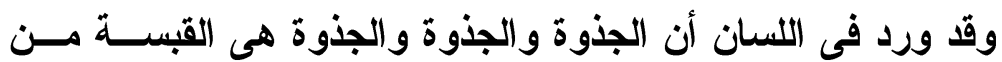

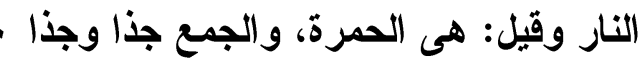

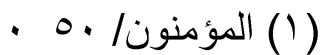

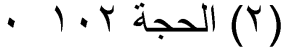

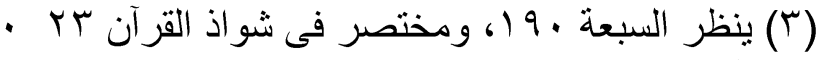

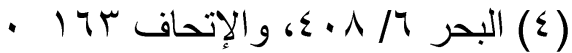

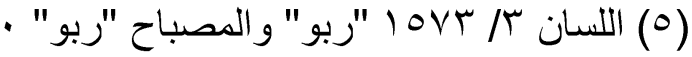

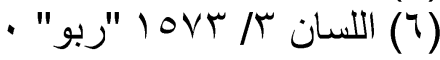




$$
-\leq \leqslant q-
$$

وقال مجاهد :" (وأوجذوةمنـــــالنار) أى قطعة من الجمر، قال: وهى بلغة جميع العرب"(1) 


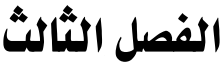

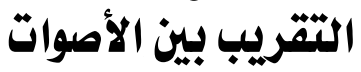

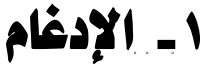

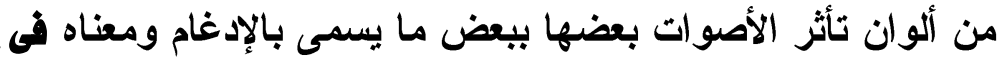

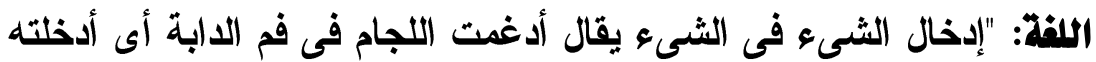

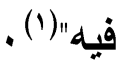

وفى الاصطلاح: "رفعك اللسان ووضعك إياه بالحرفين دفعة واحدة بعد

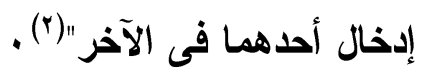
أو هو : "خلط الحرفين المتمــاثلين أو المتقــاربين أو المتجانسـين

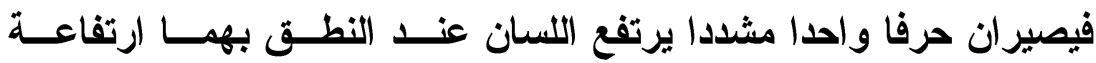

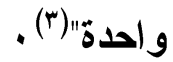

وفائدة الإدغام هى التخفيف "لأن اللســـان إذا لفــ بــالحرف مــن

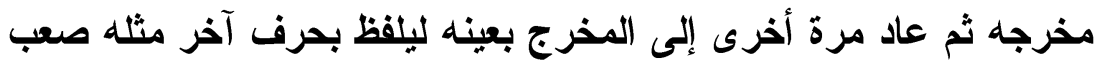

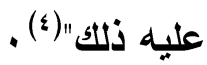

وفى ذلك يقول سيبويه : "اعلم أن التضعيف يثقل عـــى ألســنتهم، وأن اختلاف الحروف أخف عليهم من أن يكون من موضع واحد ... وذلك ألك

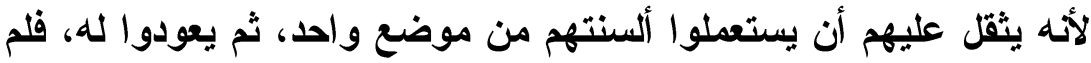

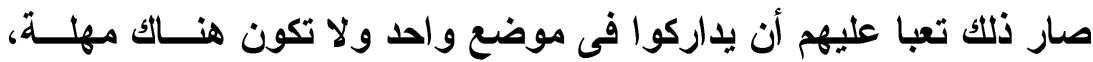

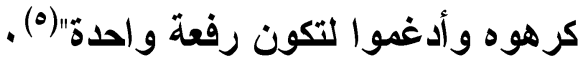

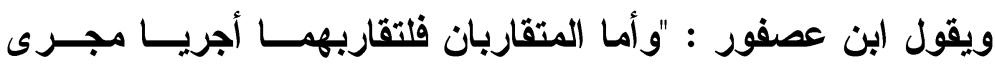

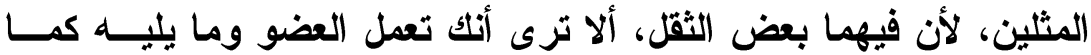

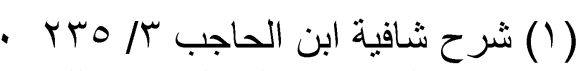

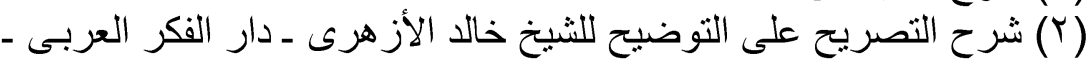
- $r q \Lambda / r$

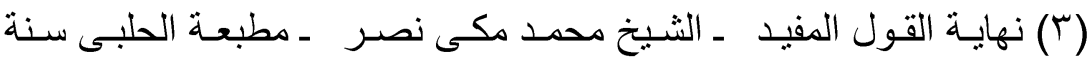

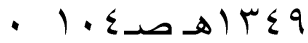

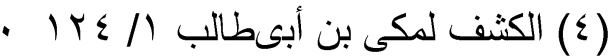

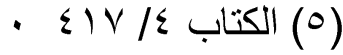


كنت فى المثلين تعمل العضو الواحد مرتين، فكأن العمل باق فى العضو لم

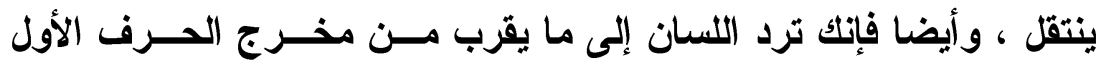

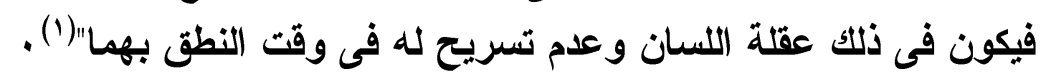

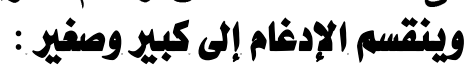

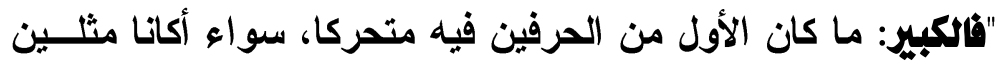

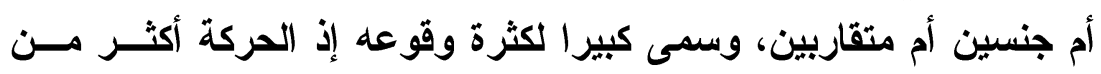

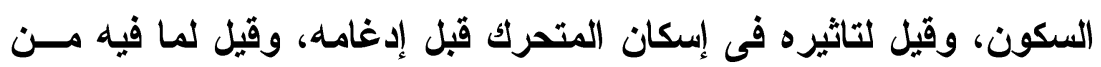

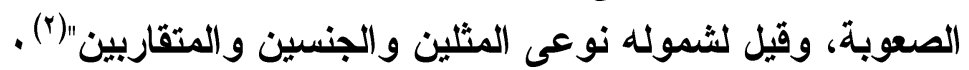

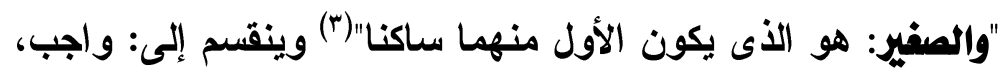

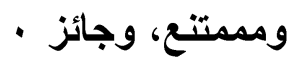

ما يجب فيه الإدغام كل حرفين متـــاثلين أو متجانســين يلتقيــان

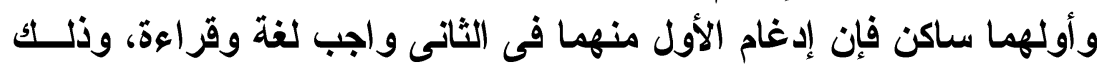

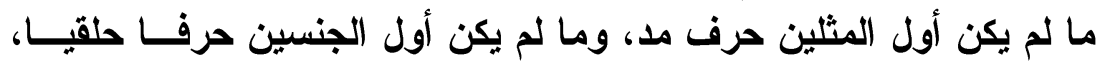

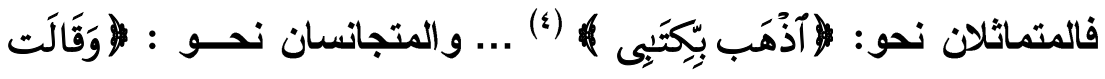

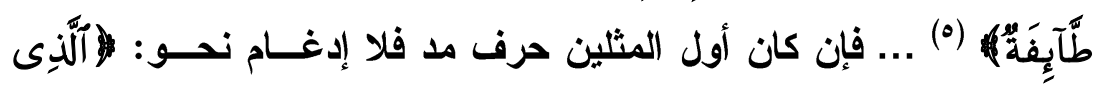

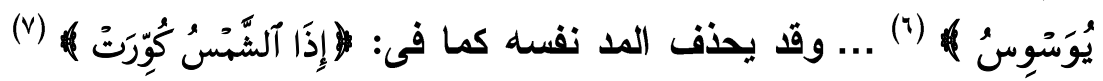

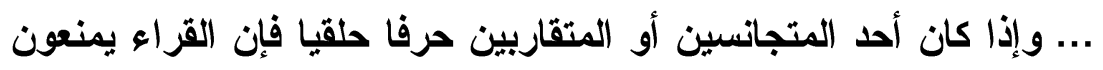

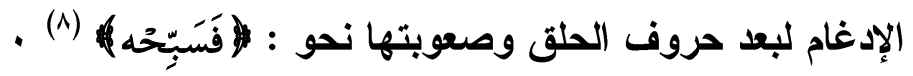

(1) الممتع فيى التصريف تحقيق د/فخر الدين قباوة ـ دار الآفاق الجديدة

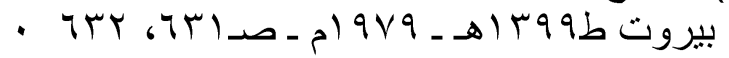

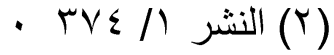

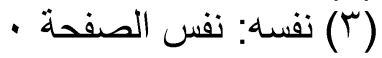

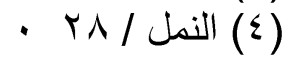

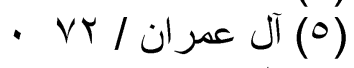

.

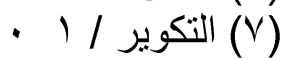

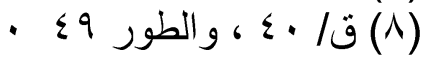


ويمتنع إدغام ما لم يستوف الثروط، ويكون الإدغام الصغير جـائزا

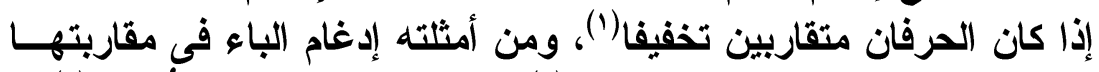

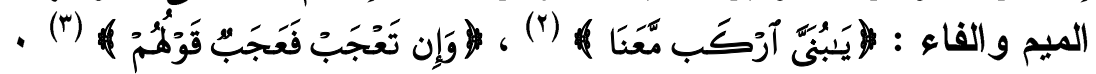

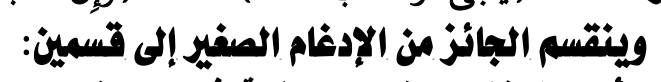

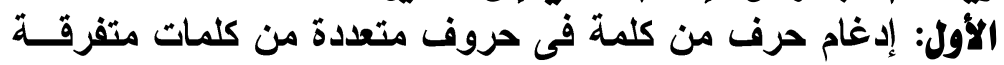

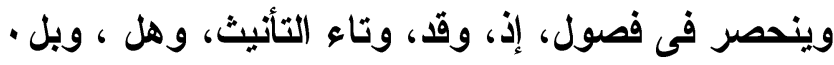

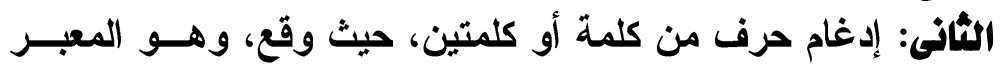

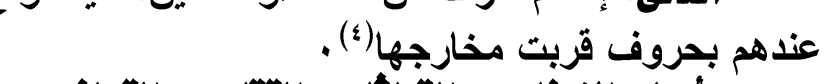

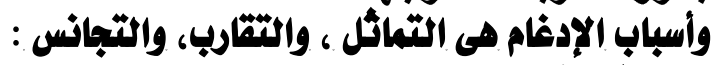

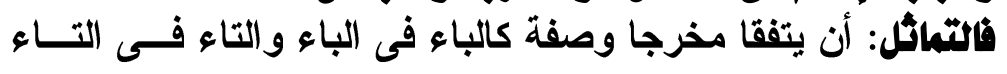

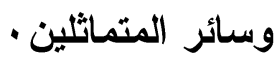

والتجانس: أن يتفقا مخرجا ويختلفا صفة كالذال فى الثاء، والثاء فى الظاء، والتاء فى الدال .

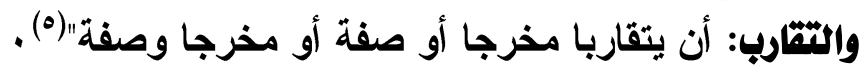

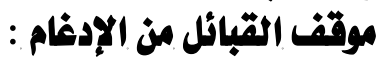

قـ نصت كتب اللغة على نسبة الإدغام إلى تميم ومجاوريها، ونسبة

$$
\text { القك إلى أهل الحجاز : أصناث }
$$

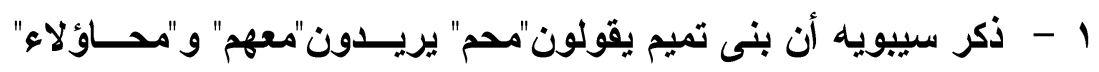

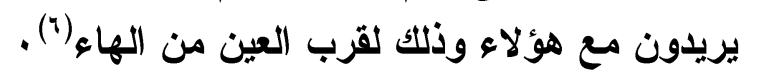

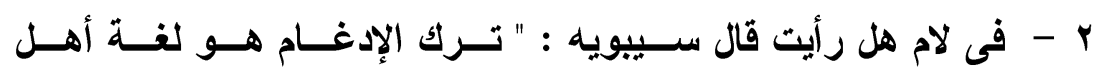

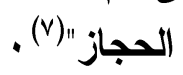

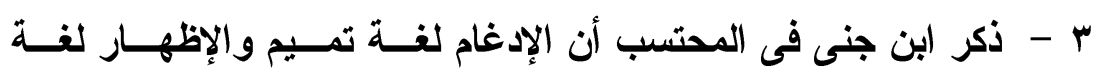

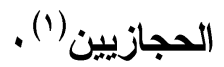

(1) اصـوات اللغـة العربيـة در اسـة نظريـة وتطبيقيـة أ.د/ محمد حسـن جبـل

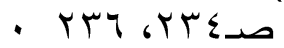

- Er/ / هو (r)

•

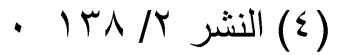

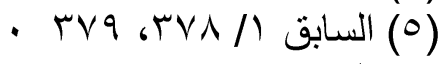

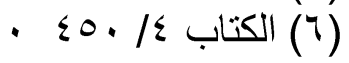

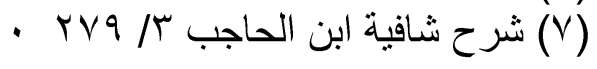




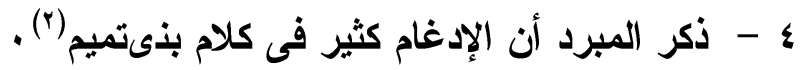

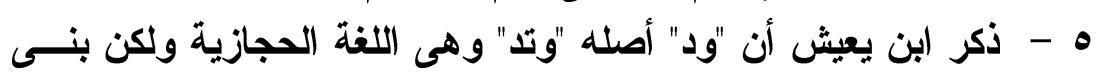

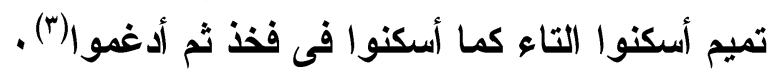

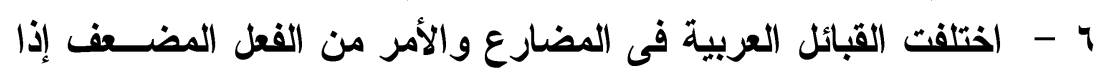

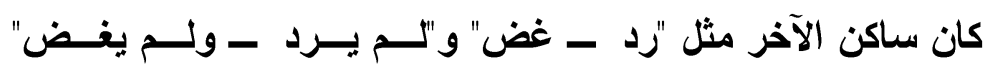

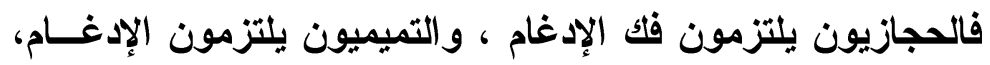

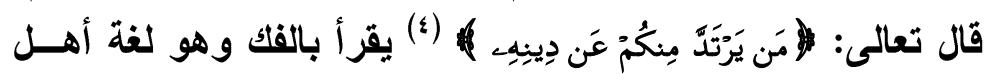

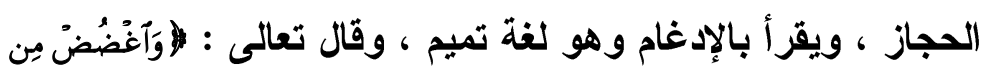

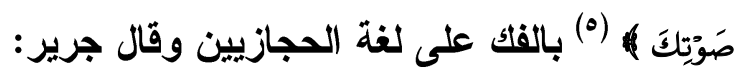

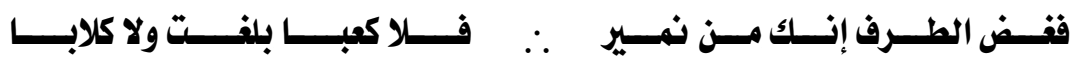

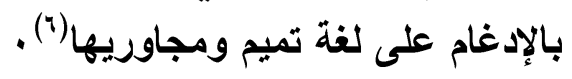

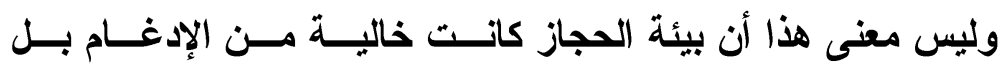

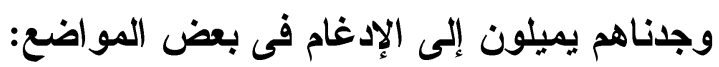

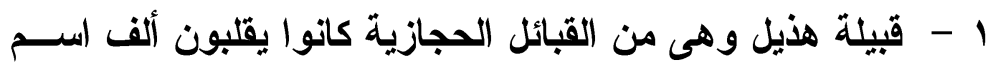

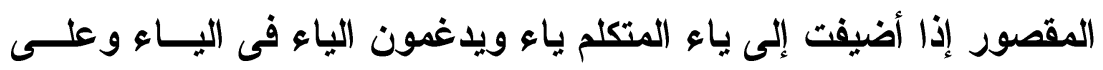

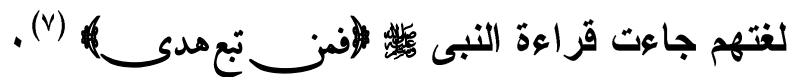

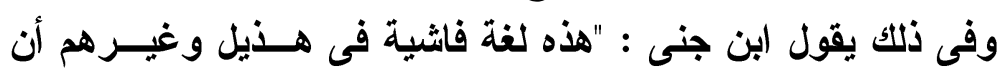

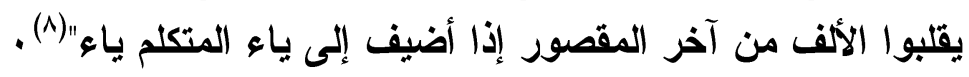

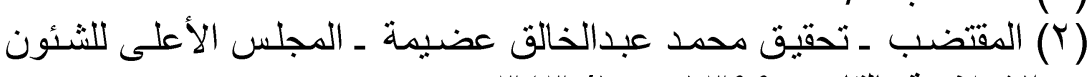

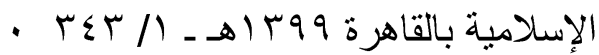

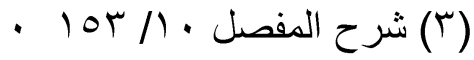

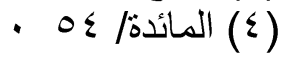

$$
\begin{aligned}
& \text { - } 19 \text { / } 19 \text { / (1) لقمان }
\end{aligned}
$$

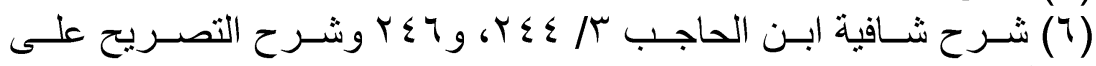

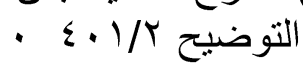

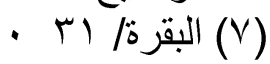


r - اختلفت القبائل العربية فى "هلم" على لغتين: إحسلهاها: أنهــا

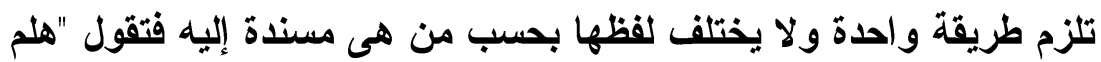

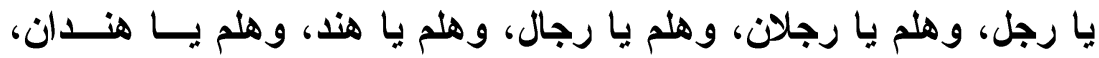

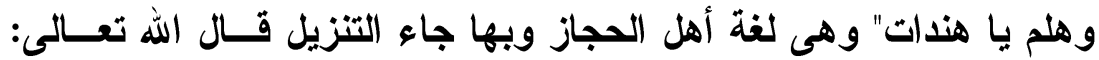

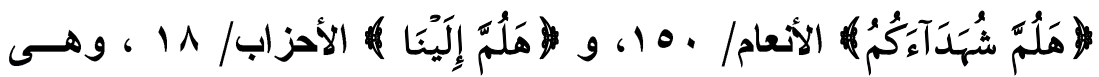
عندهم اسم فعل أمر وهى مدغمة .

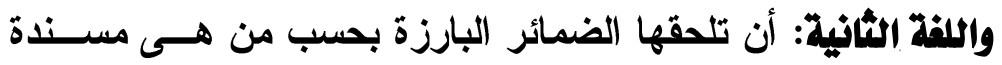

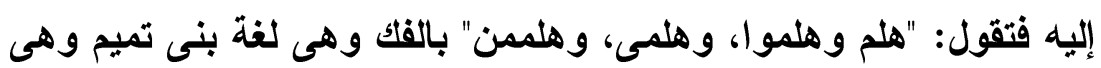

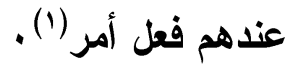

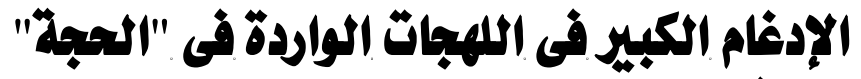

$$
\text { إلدال فى المثلين : }
$$

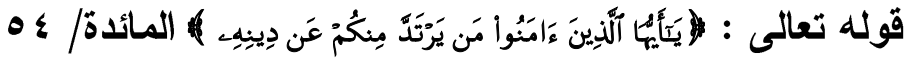

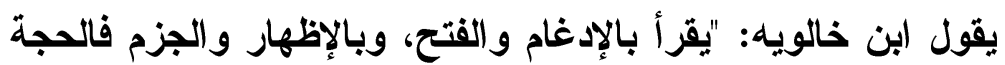

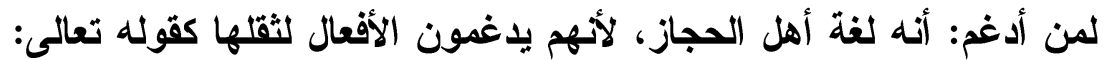

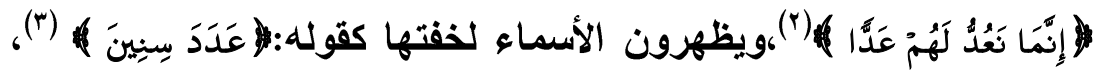

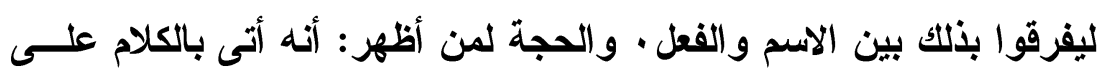

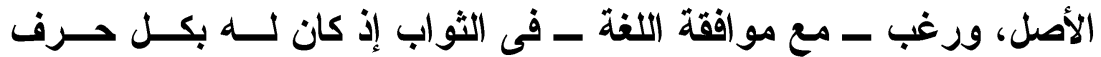

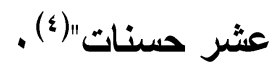

و القارئون بالإدغام هم: (بن كثير، وعاصم، وأبــوعمرو، وحمـزة،

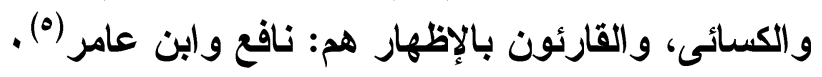

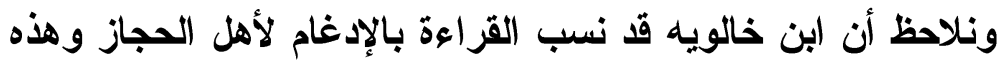

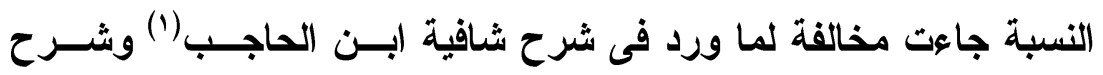

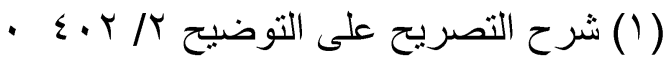

$$
\begin{aligned}
& \text { - }
\end{aligned}
$$

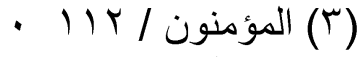

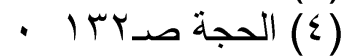

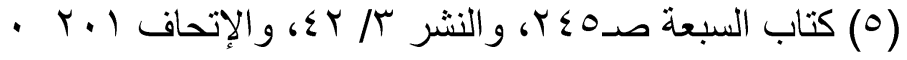




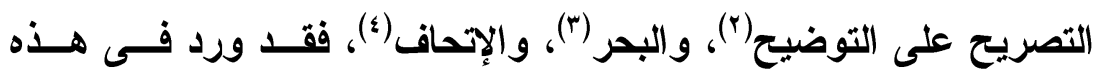

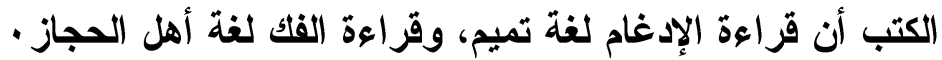

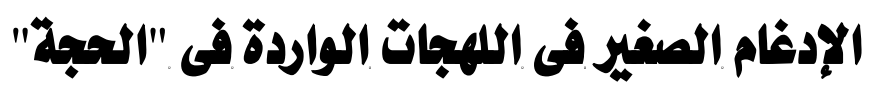
أ ـ . حروض مثقاربة فلى المخرج : الذال فى الثاء :

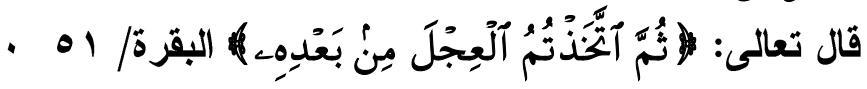

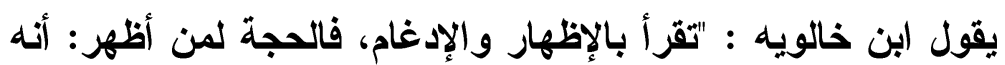

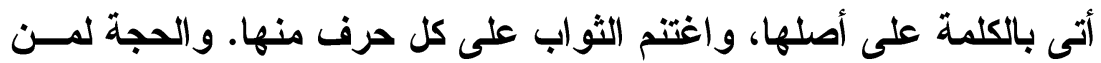
أدغم : أن الظاء والثاء، والذال مخرجهن من طرف واعلم اللسان وأطراف الثنايا

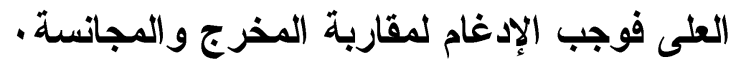

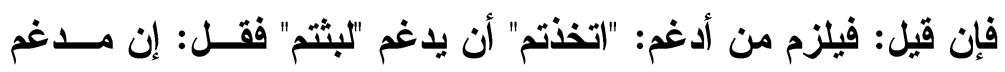

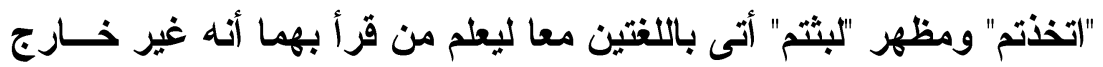

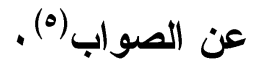

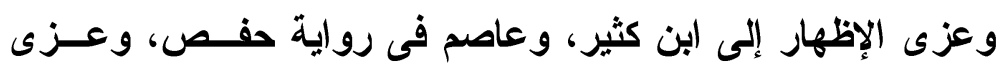

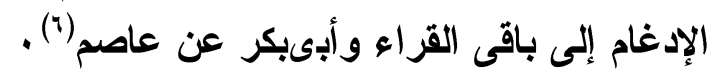

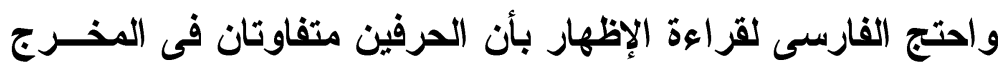

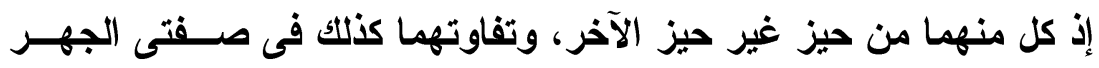
أما من قرأ بالإدغام فحجته قرب الحرفين فى المخرج، إذ حيز كـلـ و الهمس .

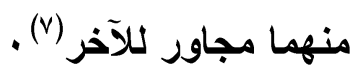

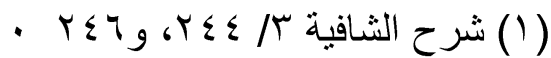

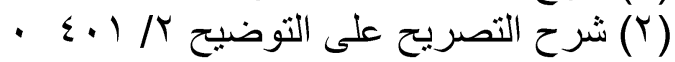

$$
\begin{aligned}
& \text {. }
\end{aligned}
$$

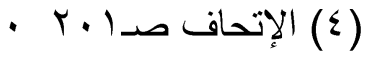

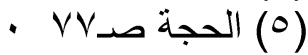

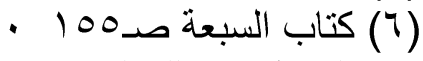

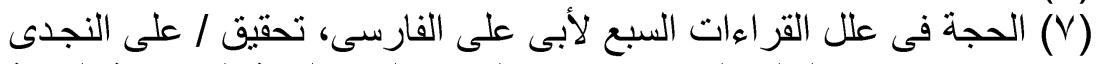

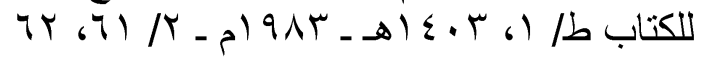

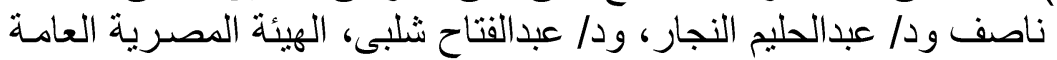




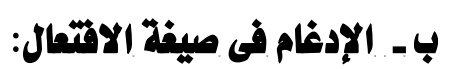

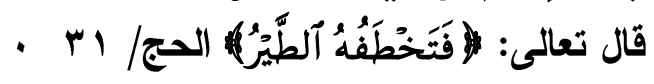

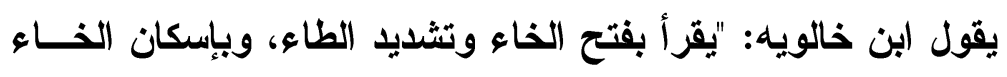

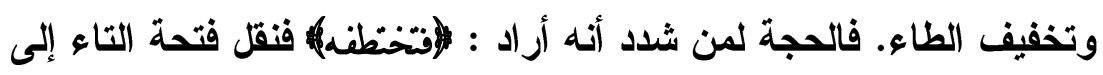
الخاء وأدغم التاء فى الطاء فثثدد لذلك .

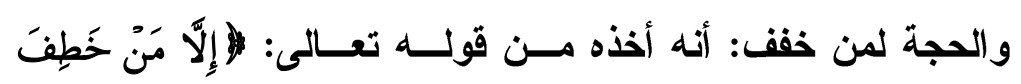

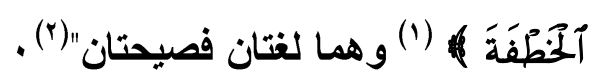

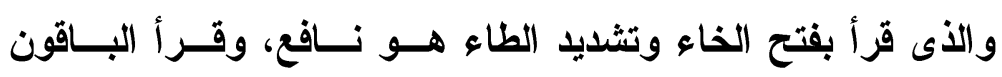

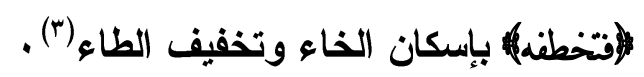

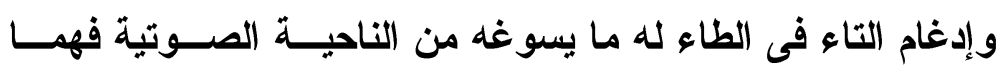

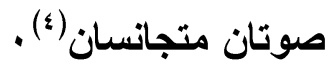

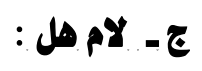

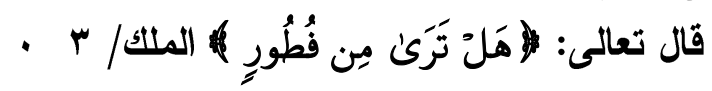

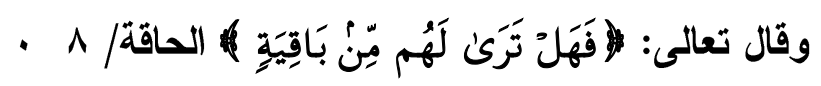

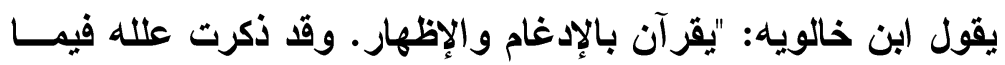

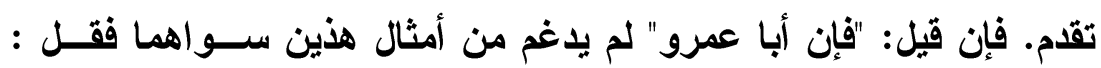

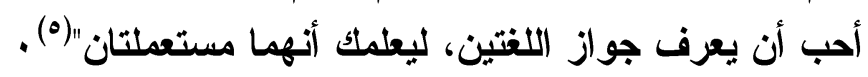

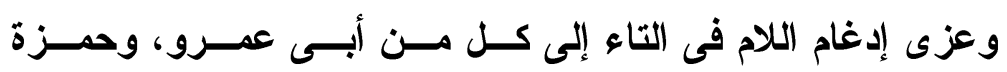

و الكسائى (").

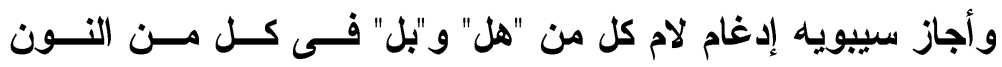

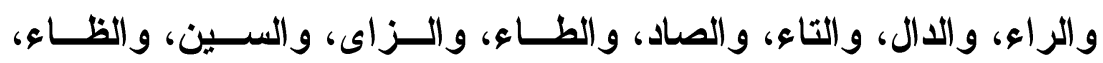

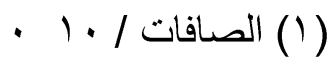

$$
\begin{aligned}
& \text { - ror r r r الحجة (r) }
\end{aligned}
$$

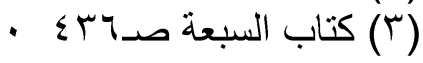

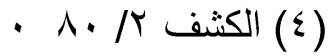

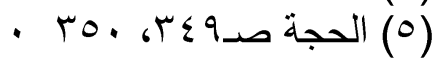

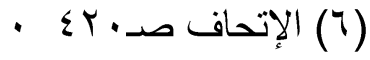


والثاء، والذال وعلل لذلك بقوله : "لأنها أقرب الحروف إلى اللام وأثبهها

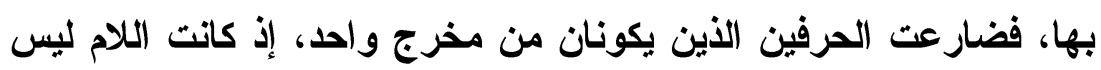

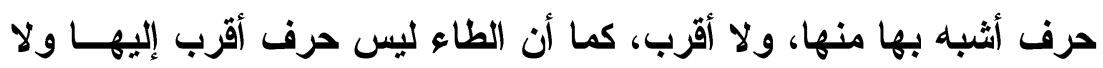

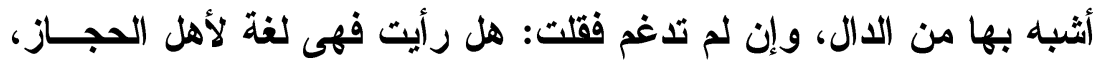

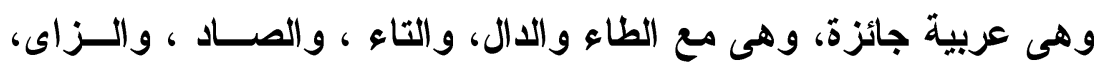

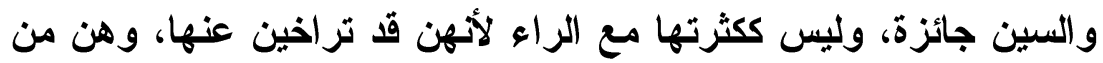

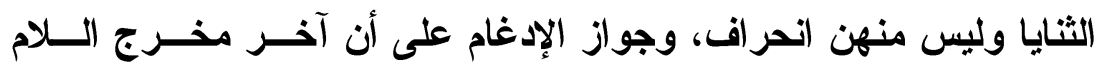
قريب من مخرجها وهى حروف طرف اللسان" (1) .

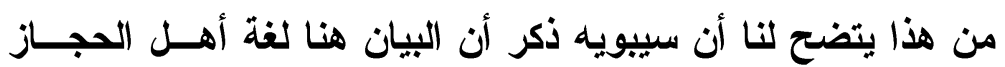

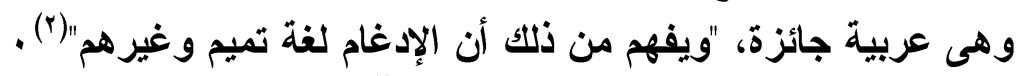

\section{r}

\section{تعريفها وأقسامها :}

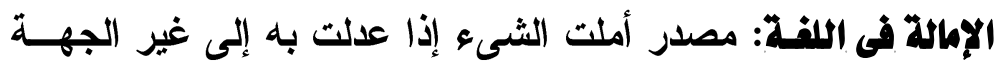

$$
\text { التى هو فيها("). }
$$

وفى الاصـطلاح: "عدول بالألف عن استوائه وجنوح به إلــى اليـاء

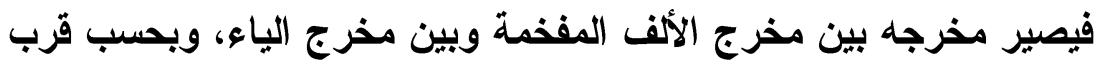

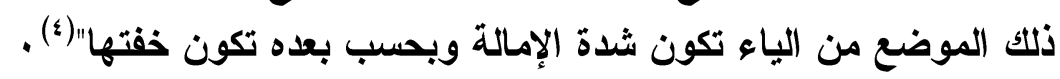

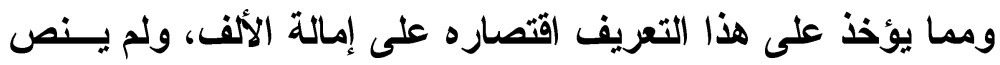

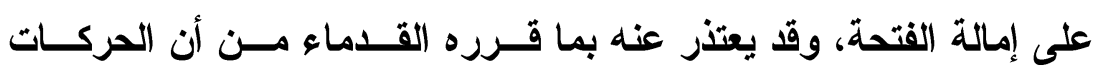

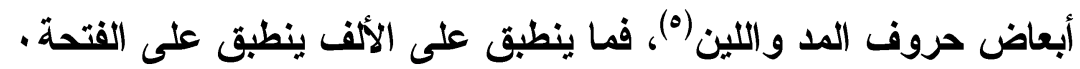

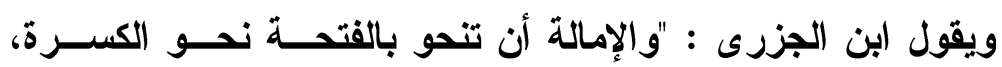

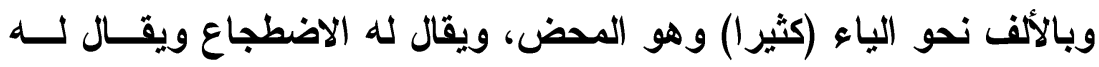

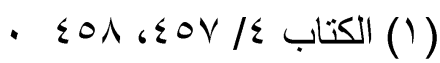

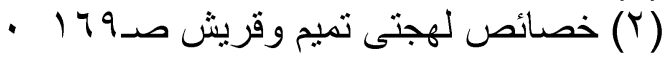

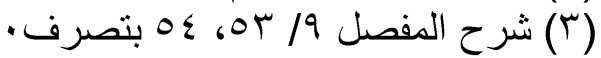

$$
\begin{aligned}
& \text { - } 0 \text { ( }
\end{aligned}
$$

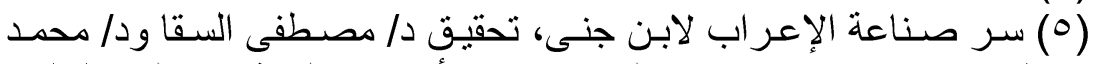

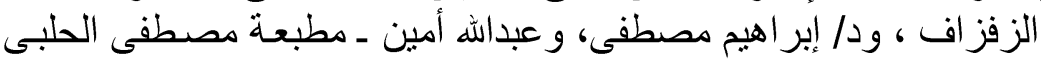


البطح، وربما قيل له الكسر أيضا. و(قليلا) وهو بين اللفظين ويقـال لــه

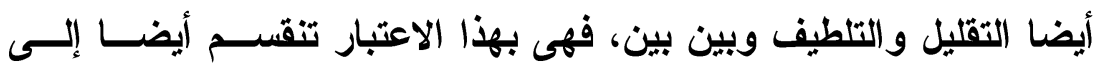

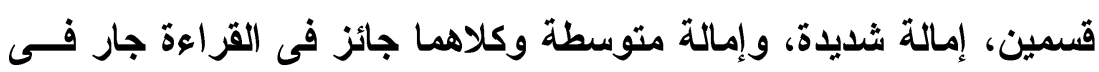

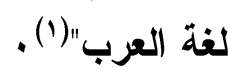
ومما يؤخذ على مثل تعريف ابن الجزرى اعتباره القتحة والكســرة

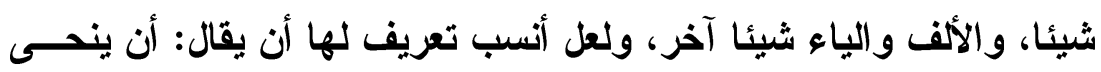
بالفتحة قصيرة أو طويلة نحو الكسرة قصيرة أو طويلة (؟) . الفرض من الإمالة:

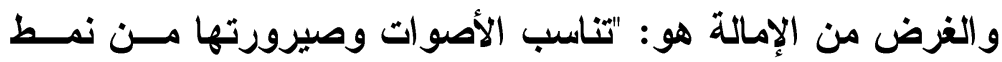

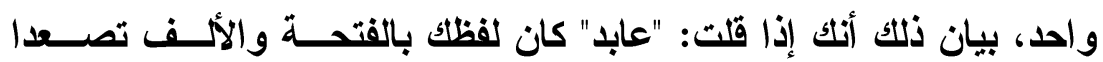

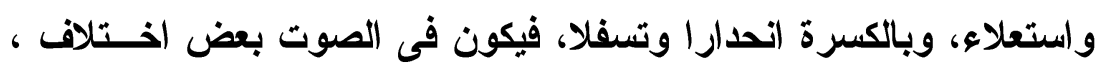

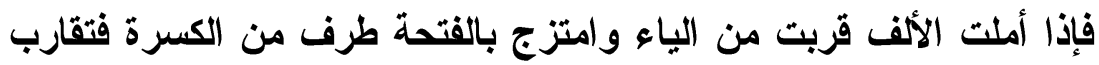
الكسرة الواقعة بعد الألف، وتصير الأصوات من نمط واحد" (بات) .

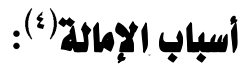

أسباب الإمالة ترجع إلى وجود الياء أو الكسرة قبل الألف أو الفتحة

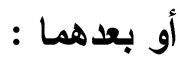
ـ فتمال الألف إذا تقدمتها كسرة، ولابد أن يكون بينهــــا فاصـلـ،

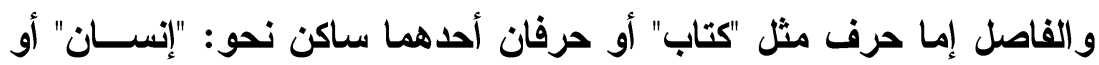

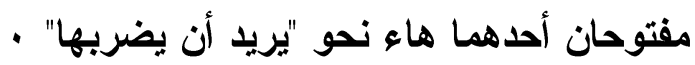

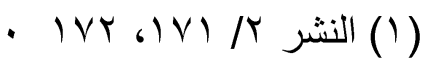

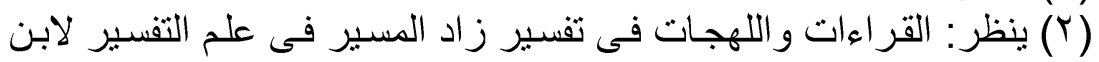

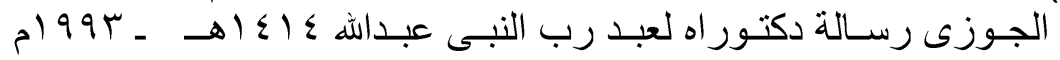
מנד (T) شـرح الأشـمونى على الألفبـة ومعـه حاشـية الصـبان ط عيسـى الحلبـى Yr./

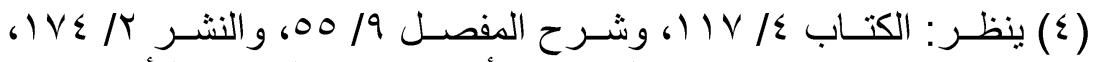

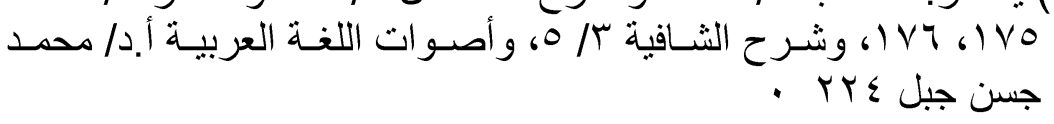




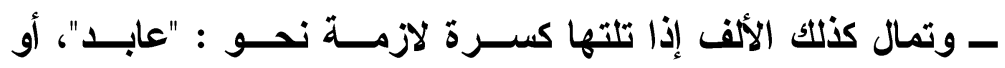

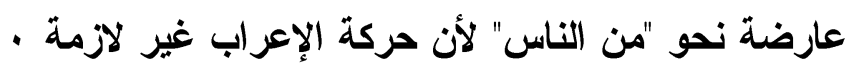

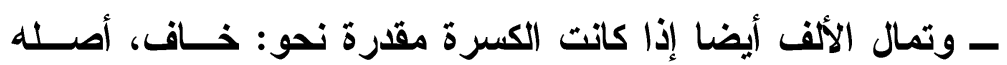

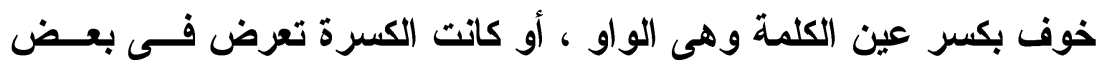

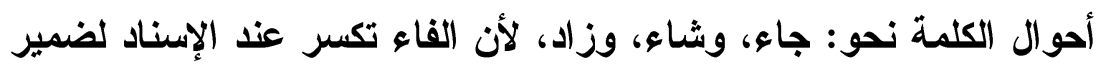

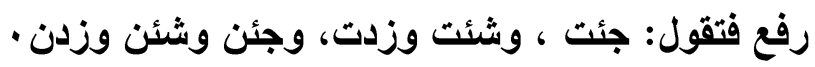

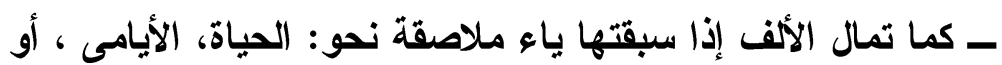

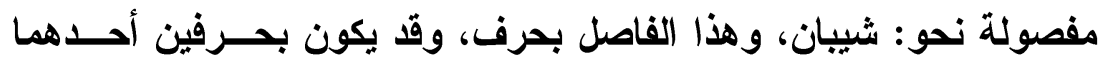
الهاء نحو: يدها، وقد يكون غير ذلكان وهن نحو: "رأيت يدنا" .

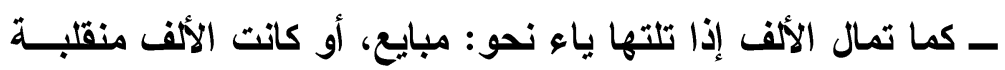

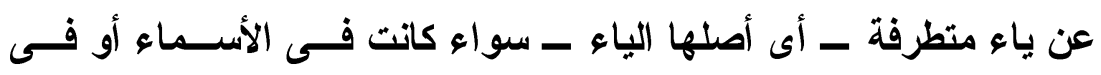

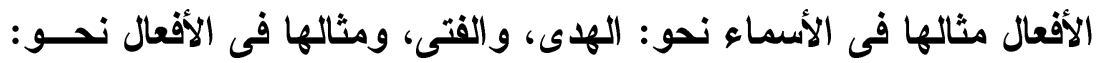

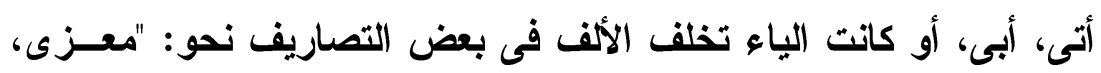

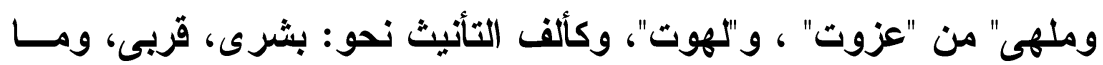

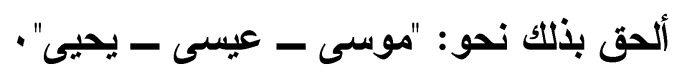
ـ كما أن هناك إمالة لأجل كثرة الاستعمال، كإمالتهم الحجاج لكثرته فى كلامهم وكإمالة كلمة "الناس" • ماله لاجل

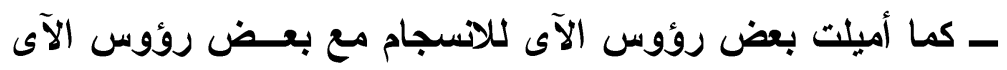
المجاورة الممالة كإمالة الضحى، وضحاها، وتلاها .

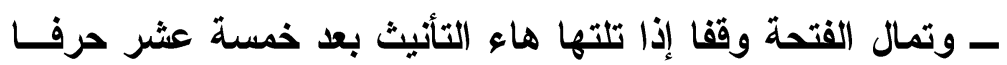

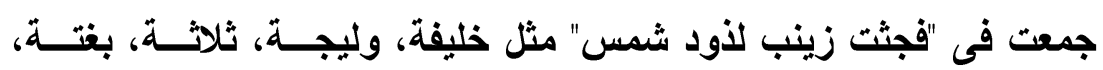

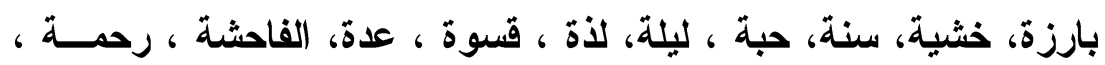

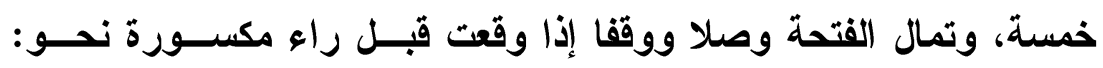

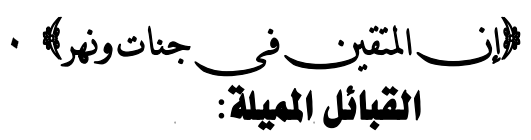

نصت كتب اللغة والقراءات على أن العرب الـــين وجــدت ظـــاهرة الإمالة فى لغتهم هم : لغكت 


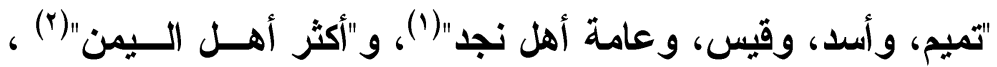

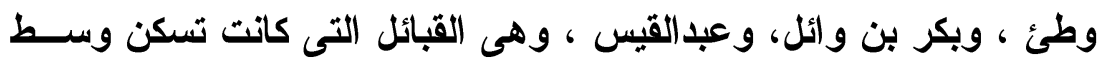

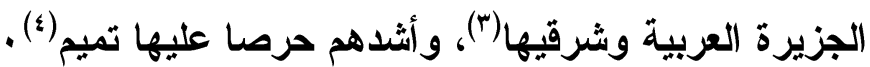

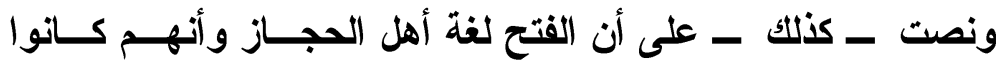

يميلون فى بعض المواضع(0).

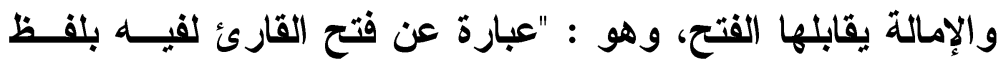

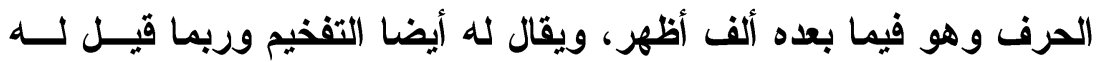

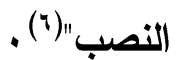

وينقسم الفتح إلى "فتح شديد، وفتح متوسط ، فالثديد هــو نهايــة

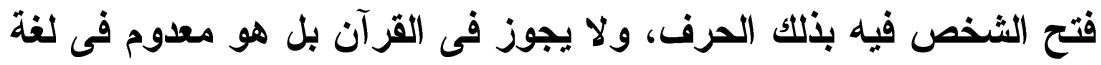

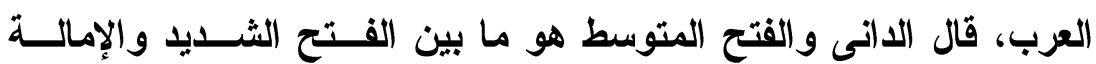

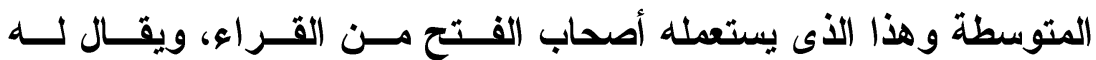

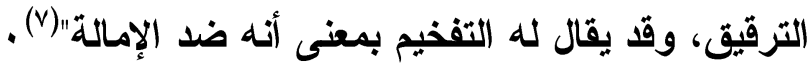

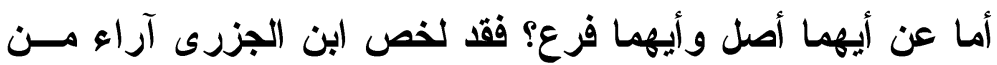

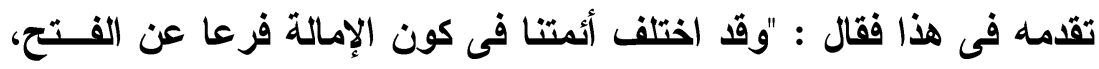

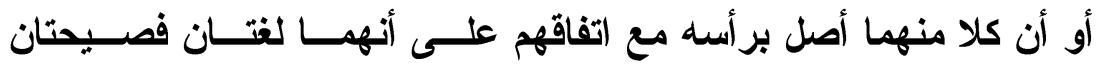

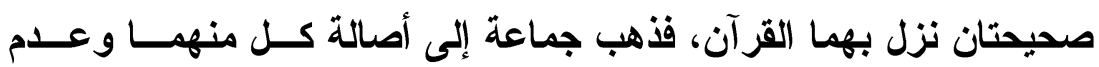

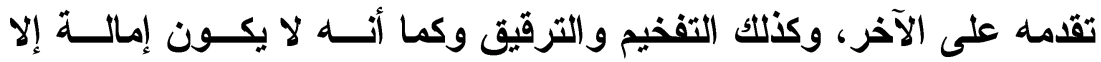

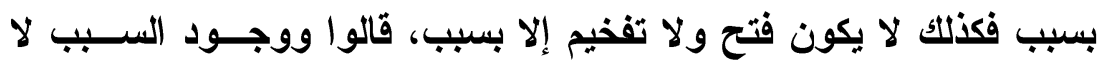

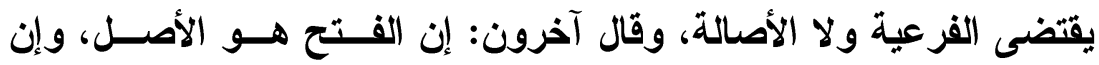
الإمالة فرع بليل أن الإمالة لا تكون إلإلة عند وجود سبب من الأسباب، فإن الأن

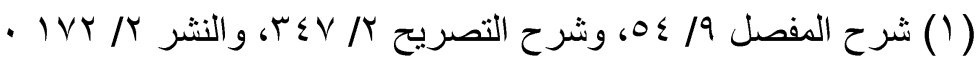

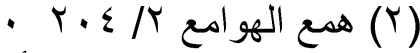

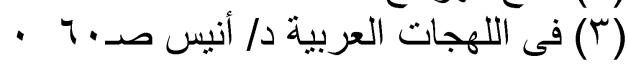

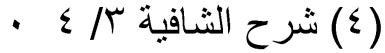

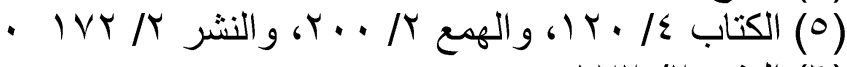

$$
\begin{aligned}
& \text { - IVT/r النشر (7) } \\
& \text { (السابق : نفس الصفحة ( (Y) }
\end{aligned}
$$


فقد سبب منها لزم الفتح، وإن وجد شىء منها جاز الفتح والإمالة، فما من

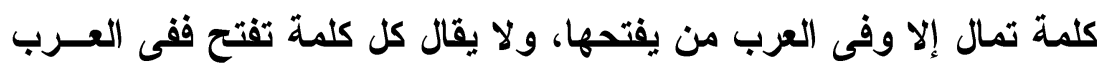

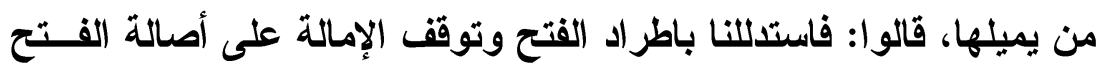

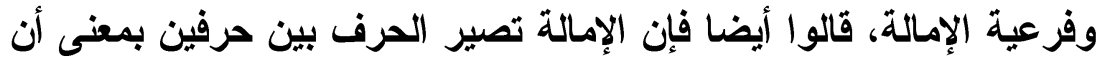

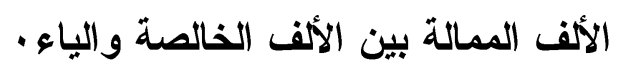

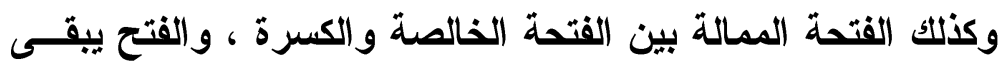

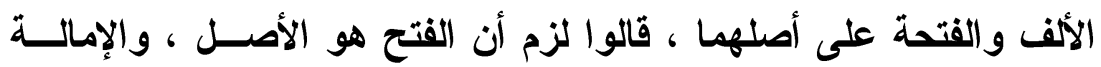

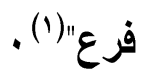

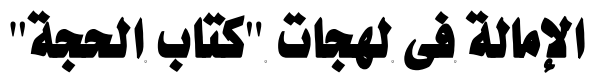

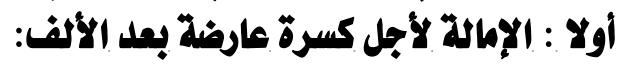

$$
\begin{aligned}
& \text { ورد هذا فيما يأتى : }
\end{aligned}
$$

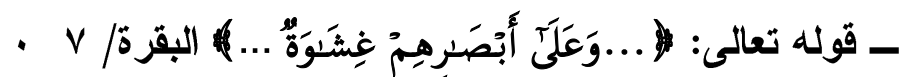

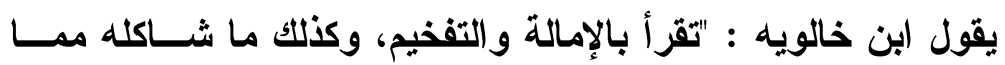

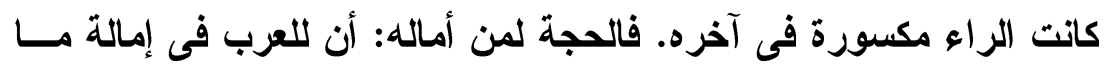

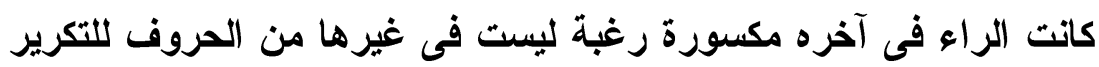

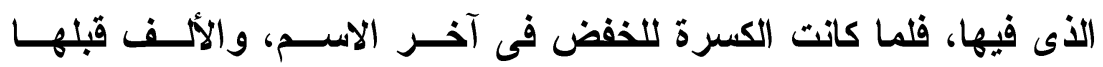

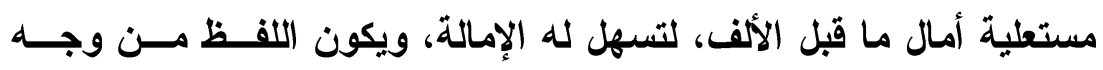
واحد.

والحجة لمن فخم: أنه أنى بالكلام على أصله ووجهه الذى كان لــه

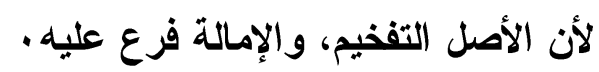

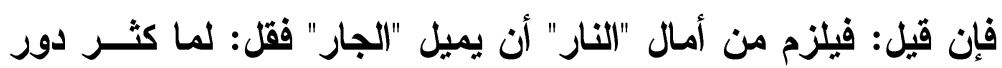

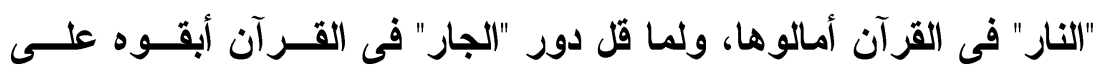

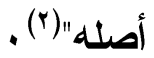


وأمال (أبصارهم) أبوعمرو، وابن ذكــوان مــن طريـق الصــورى

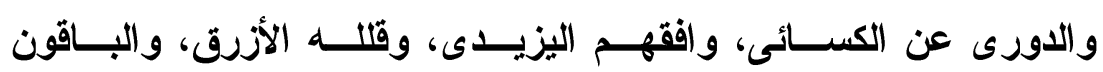
بالفتح (') - (الاوري عن

ومن الملاحظ أن ابن خالويه قد انضم للفريق الأى يرى أن الفـتح

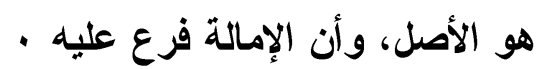

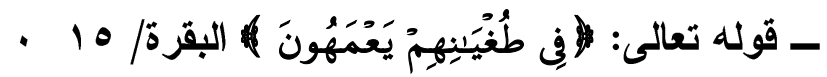

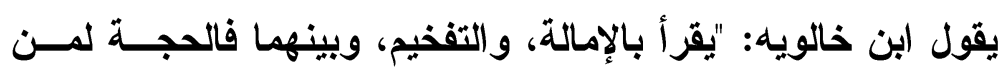

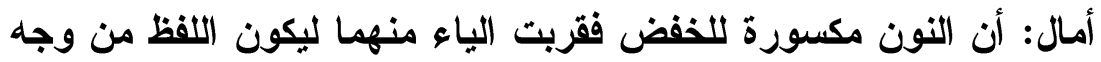

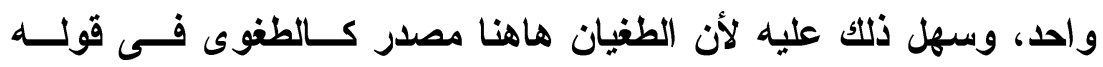

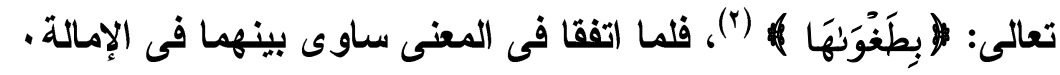
والحجة لمن فتح: أنه أتى بالكلام على أصل ما بنى عليه.

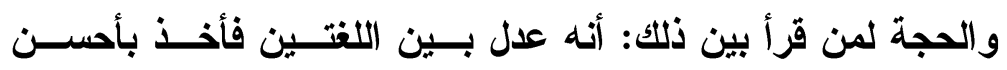

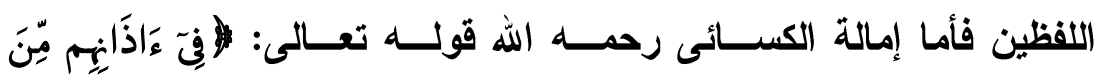
آلصَّوَ'عِقِ ) (r) فإن كان أماله سماعا من العرب فالسؤال عنه ويـلـل، وإن كان أمساله قياسا فقد وهم، لأن ألف الجمع فى أمثال هذا لا تمال، ويلزمسـهـ

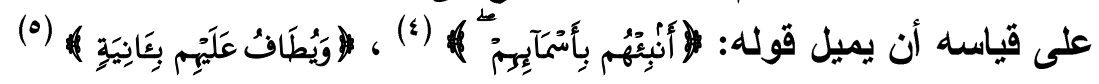

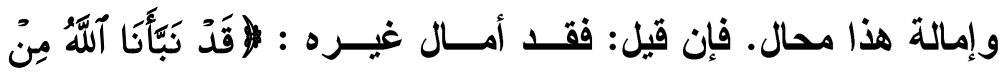

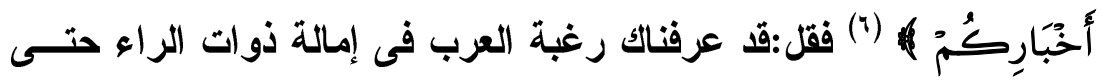

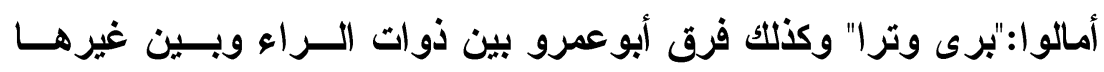




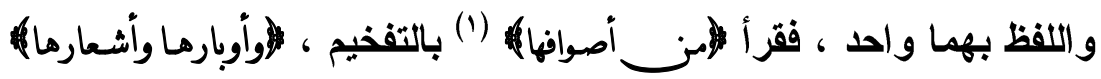

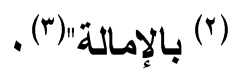

وقال أبوعمرو الاورى ونصير بن يوسف النحوى : كان الكسـائى

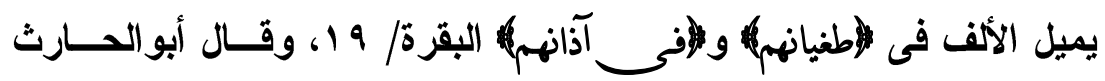

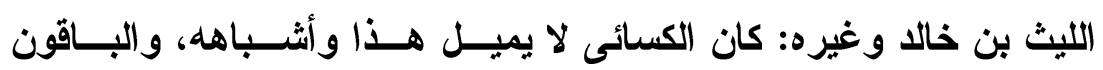

\section{ثانيا : الإمالة لأجل كسرة تعرض فى بعض أموال الكلمة:}

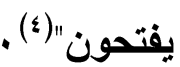

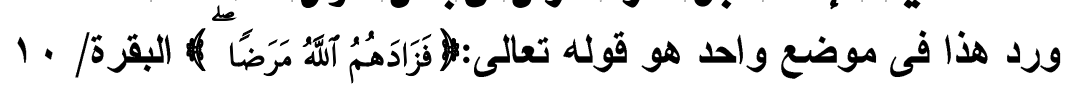

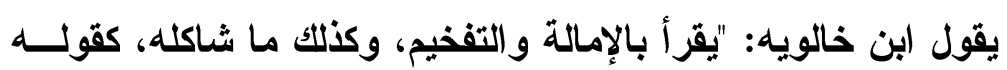
شاء، وخاف، وجاء، وضاق، فالحجة لمن أمال كسر أوائل هذه الأله الأفعال إذا

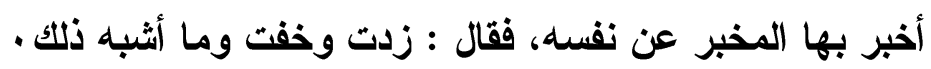

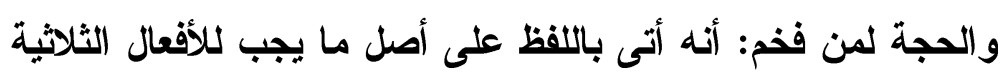

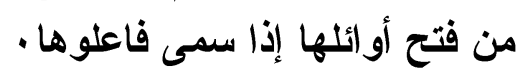

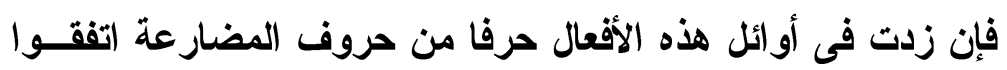

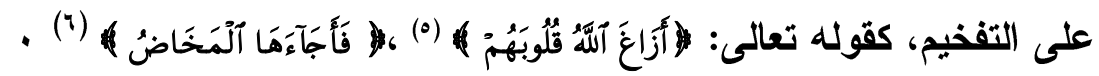

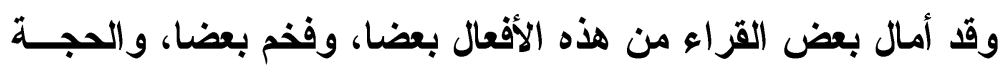

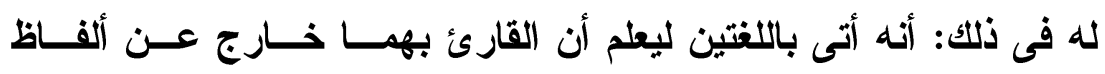

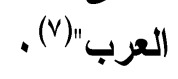

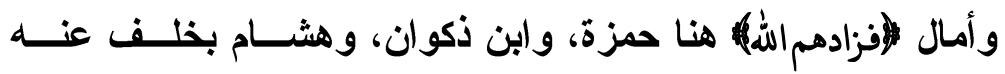

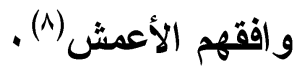

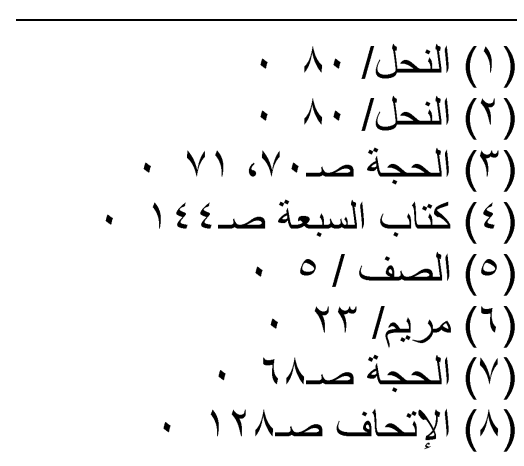




\section{كالثا: إمالة الألف المنقلبة عن ياك:}

ورد هذا فى المواضع الآتية:

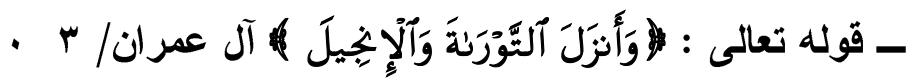

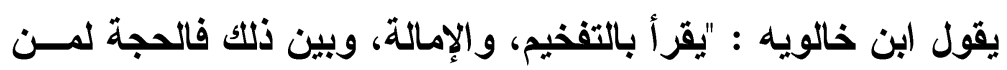

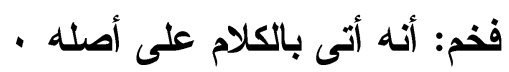

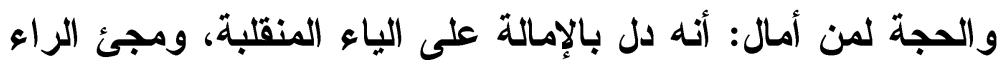

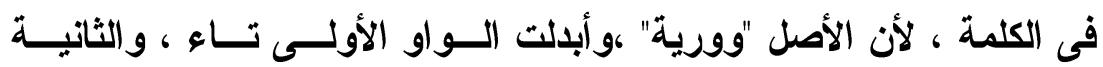

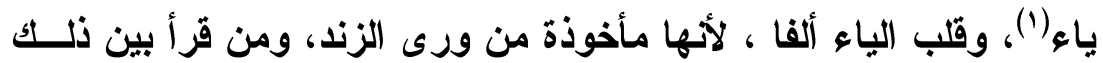

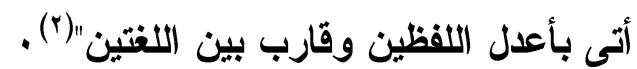

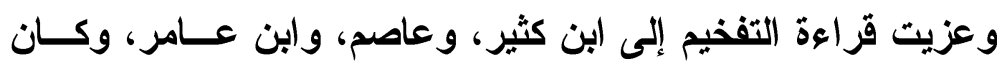

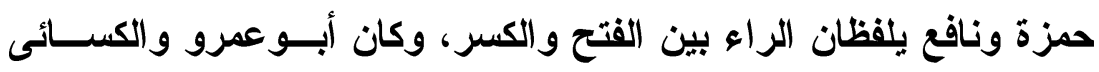

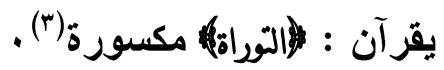

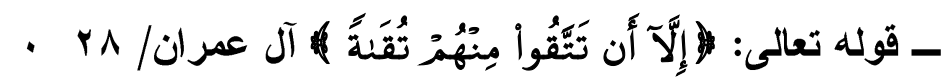

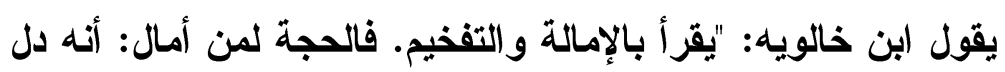

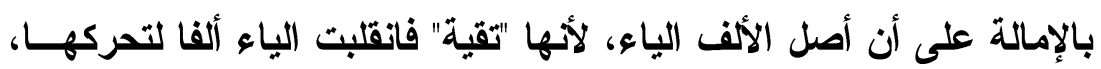

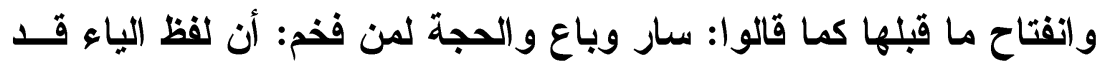

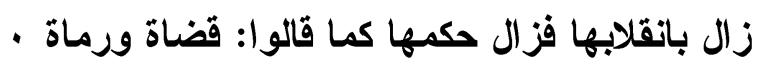

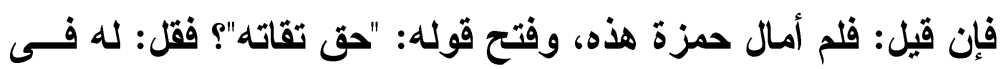

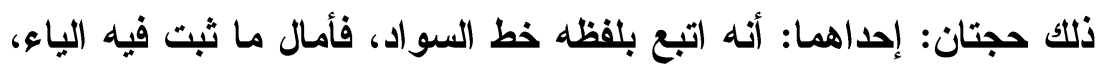

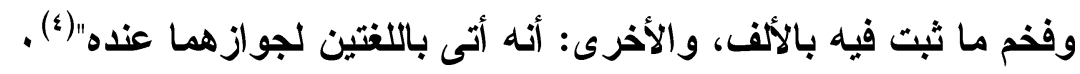

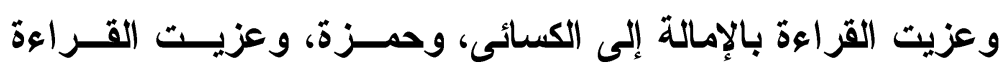

$$
\text { بالفتح إلى باقى القراءع) (هزاء). }
$$

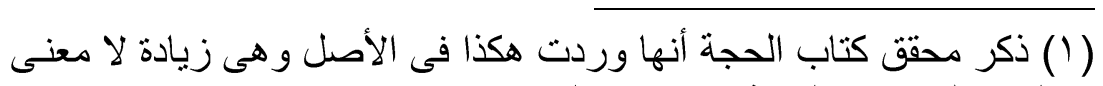

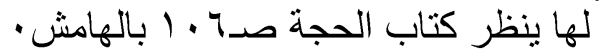

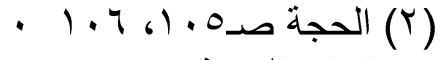

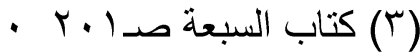

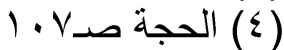

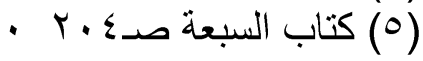




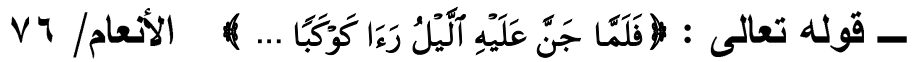

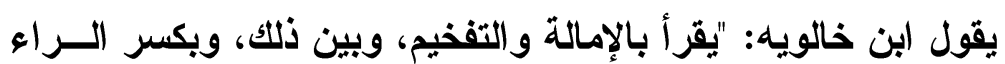

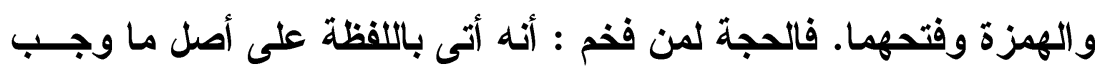

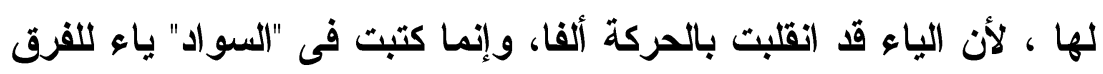

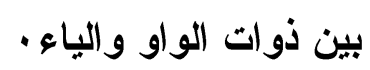

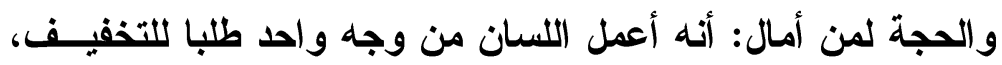

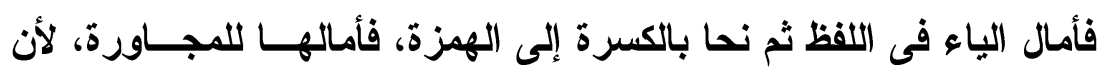

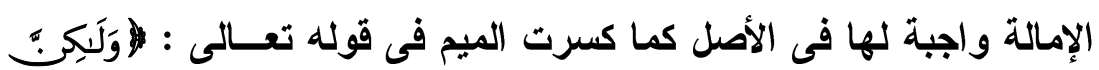

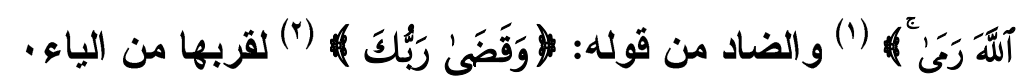

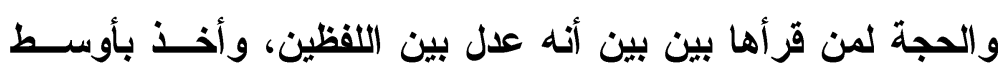

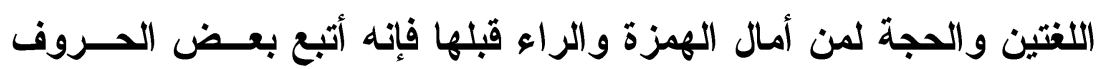

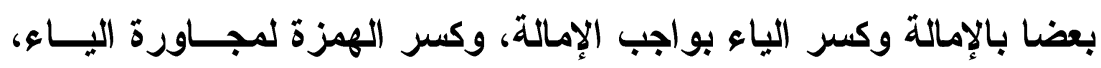

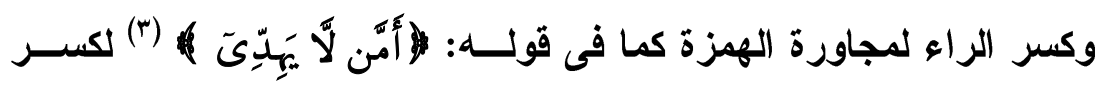

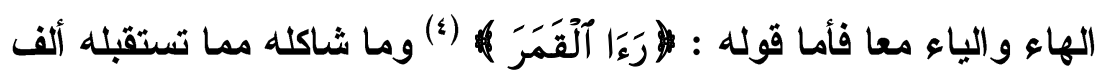

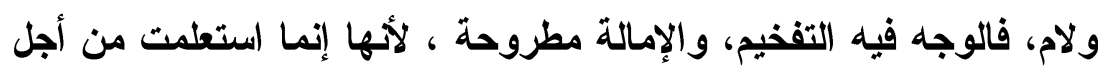

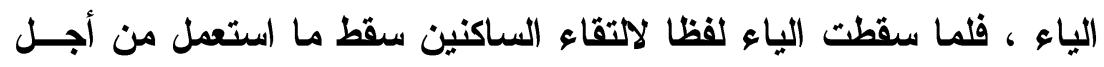

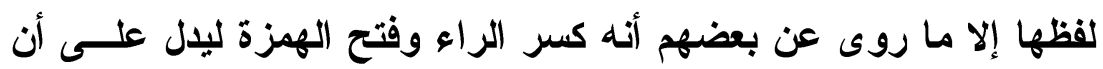

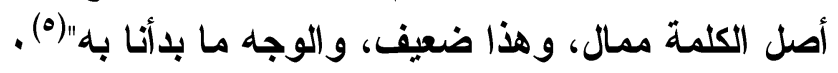

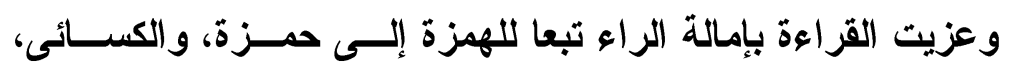

وخلف، وأبىبكر (").

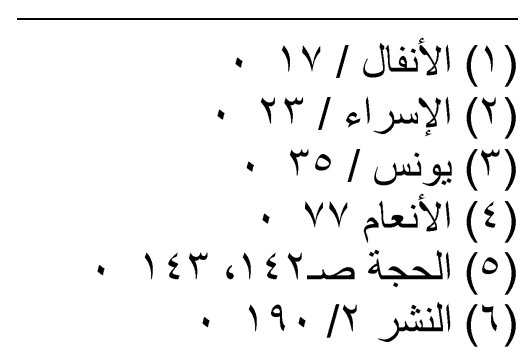


وقرأ ابن كثير وعاصم فى رواية حفص : (لرها) بفتح الراء والهمزة وقرأ نافع: بين الفتح و الكسر، وقر أ أبوعمرو : (لروما) بفتح الــراء وكسـر الهمزة، وروى عنه أيضا : (لرء|) بكسر الراء والهمزة جميعا وقرأ عاصم فى رواية أبىبكر، وابن عامر، وحمزة، والكسائى : (لرء|) بكسـر الــراء

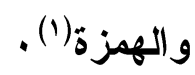

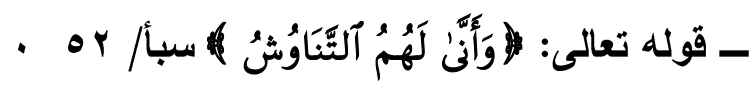

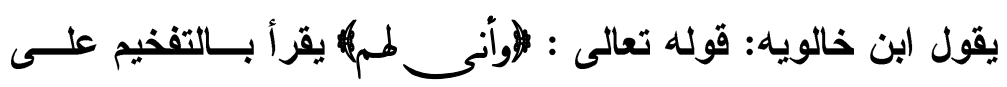

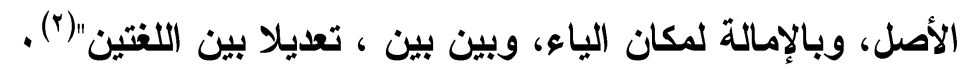

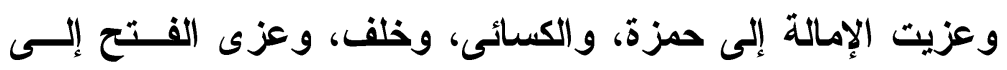

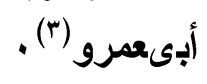

\section{رابعا : الإمالة فى حروف الهجاء ."فواتع السور" :}

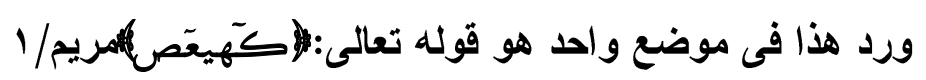

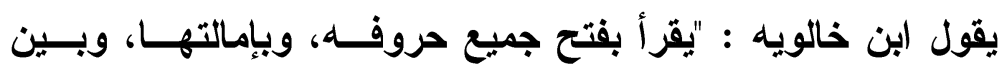

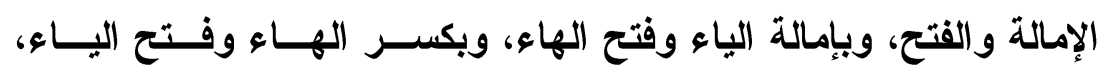

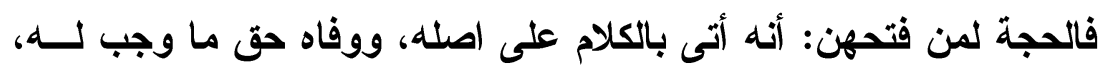

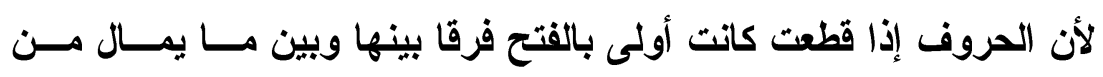

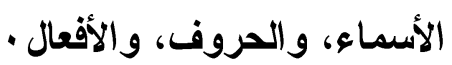

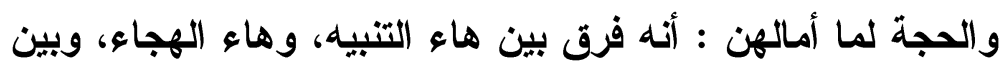

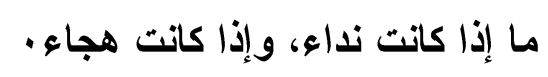

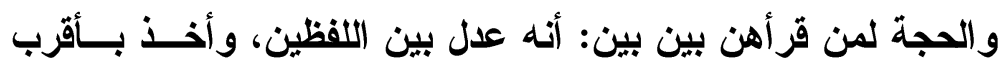


والحجة لمن أمال بعضا، وففم بعضا: أنه كره تو الى الكســرات أو بو بوات

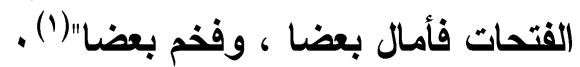

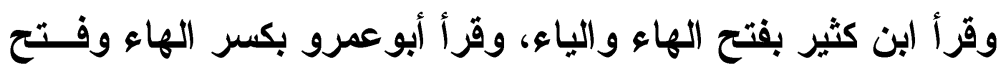

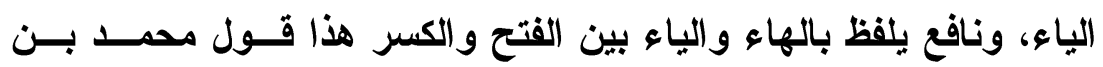

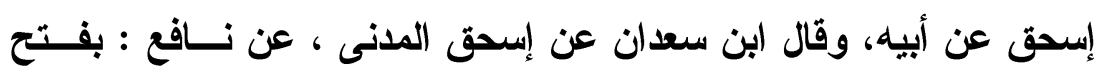

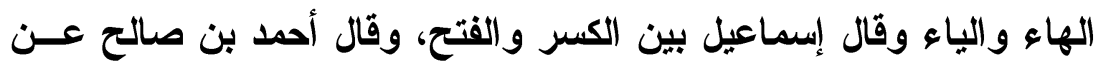

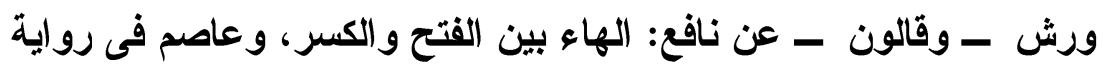

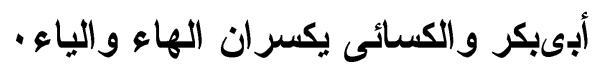
وقرأ حمزة، وابن عامر بفتح الهاء وكسر الياء() الهاء)، وعزيت القراءة

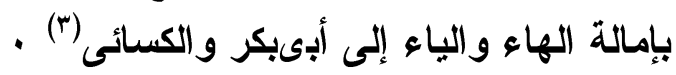

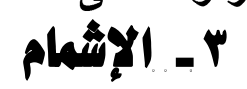

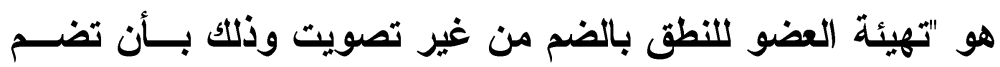

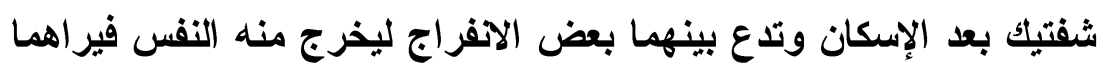

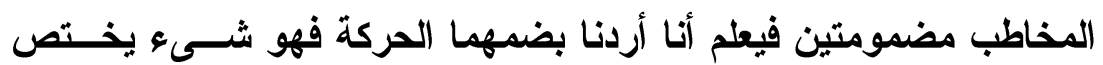
العين دون الأنن" (\&).

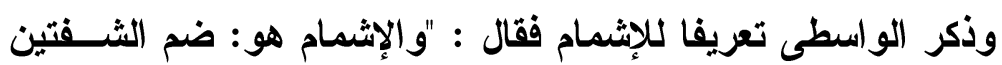

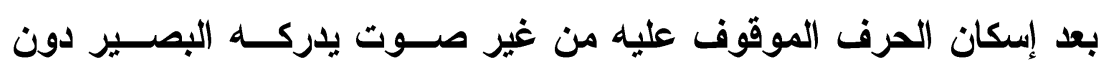

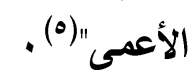

فائدة الإشعام : "إبانة نوعية الحركة للسامع المبصر، بخلاف الحسال

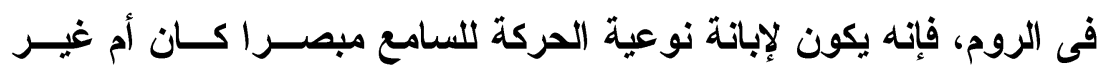

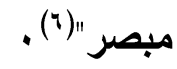

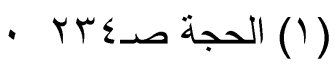

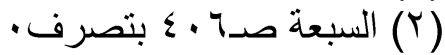

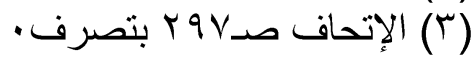

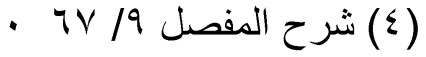

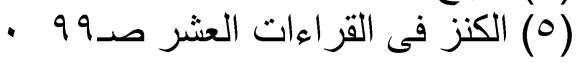

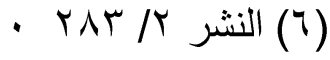


سياقاته : يدخل الإثمام من الحروف الحرف المضموم، ولا يـــخل

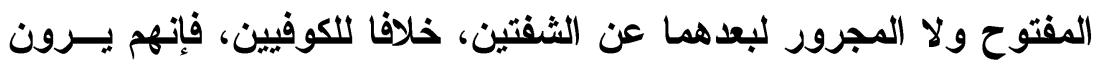

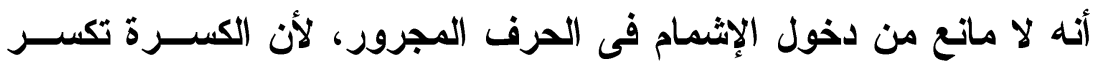

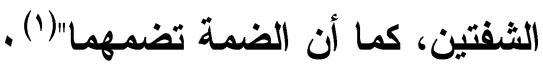

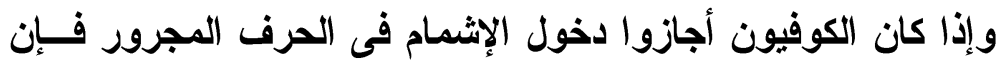

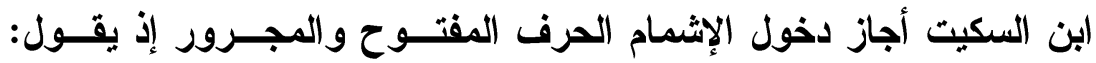

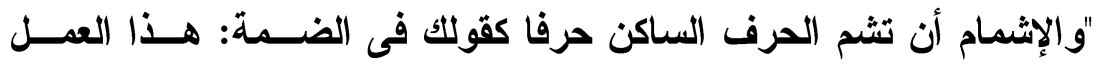

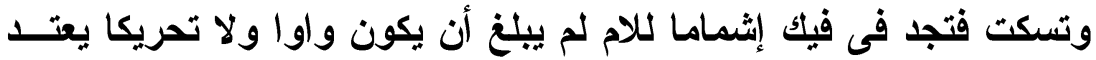

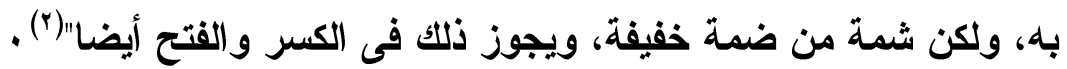
وذكر نصر بن على الثبيرازى فى كتابه الموضح:

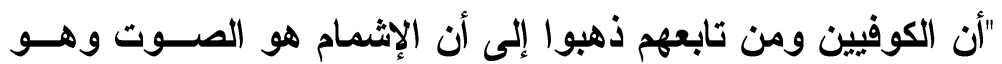

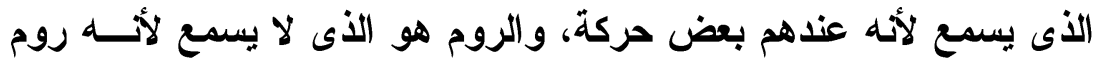

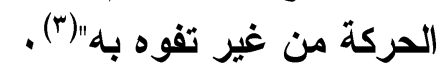

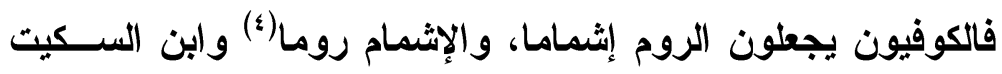

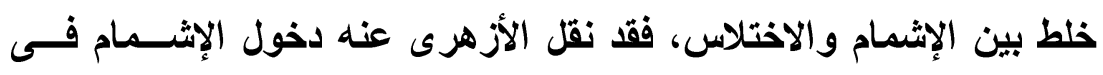

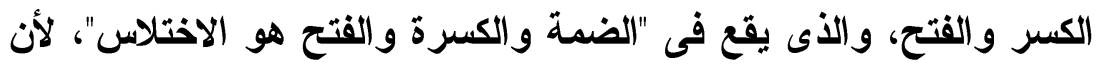

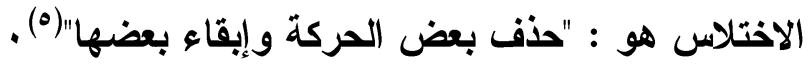
أنواعه (") : الأول: ضم الثفتين بعد نطق الصوت الموقوف عليه مباشرة، وذلك

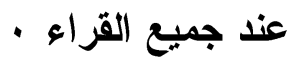

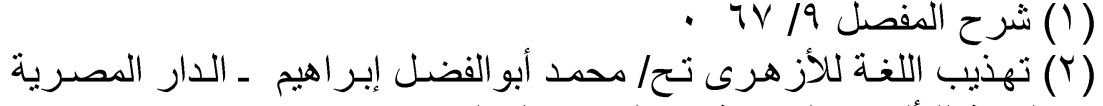

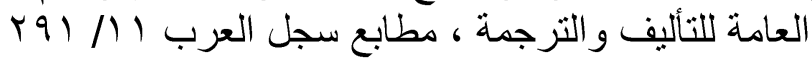

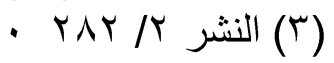

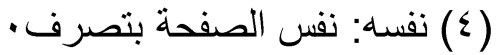

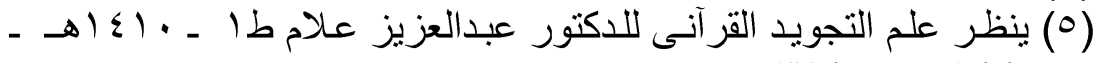
(7) (ال السابق : نفس الصفحة. 
الثانى: إخفاء الحركة بين الحركة و الساكن، كما فى قوله : (لألاتمنا)

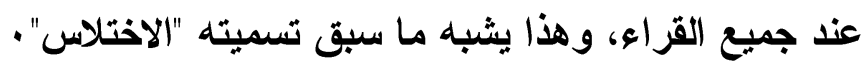

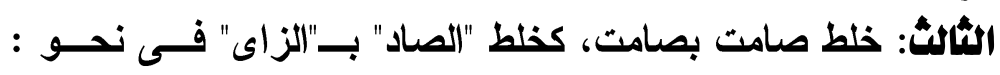

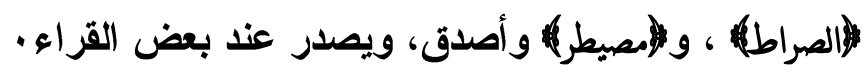

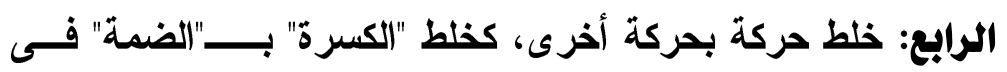

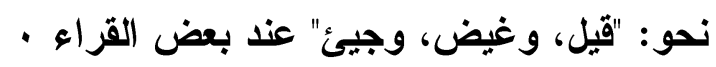

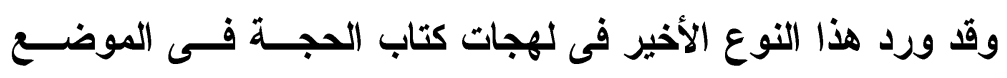
الآتى:

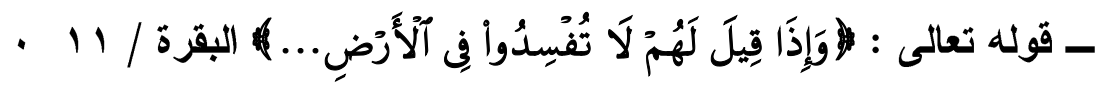

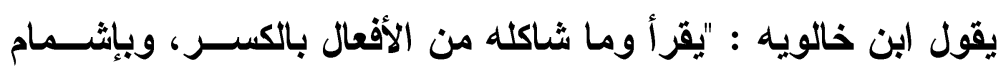

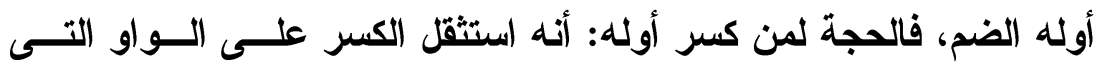

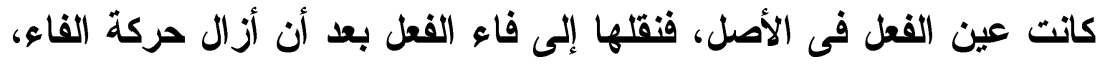

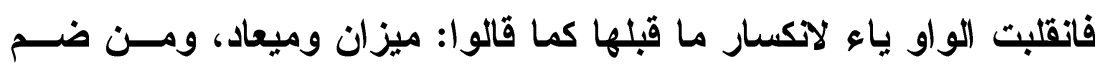

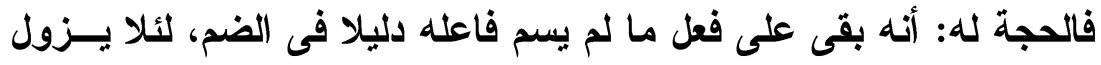

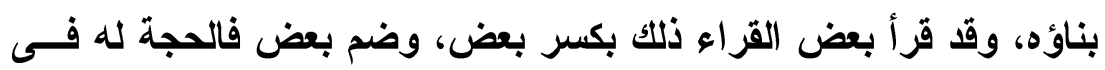

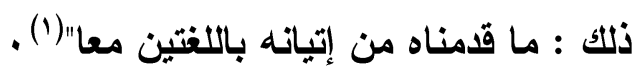

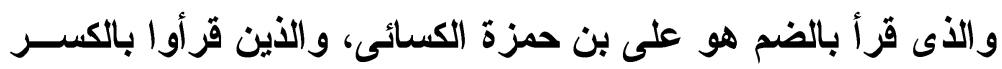

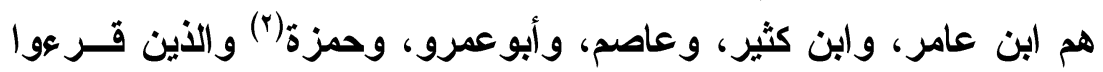

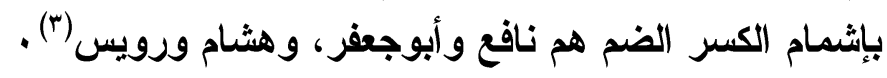

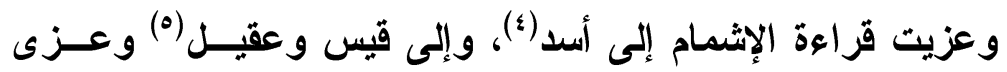

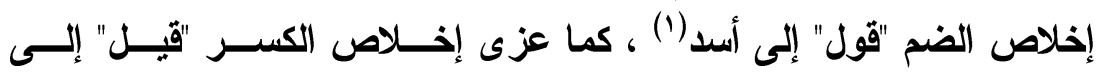

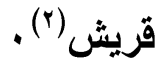

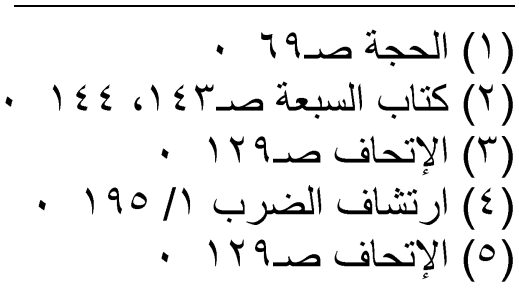


- $\Sigma$ V. -

(1) البحر // (1/ • • و اللسان : "قول" •

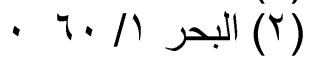




\section{الفصل الرابع الفي

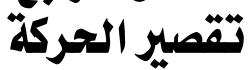 \\ أولا : تقصير الحركة الطويلة}

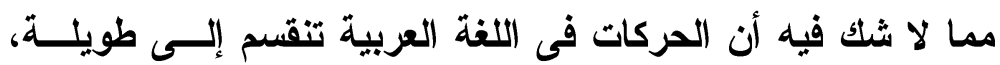

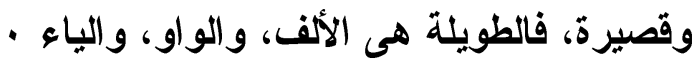

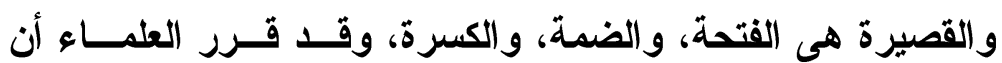

الفتحة بعض الألف، والضمة بعض الواو، والكسرة بعض الياء .

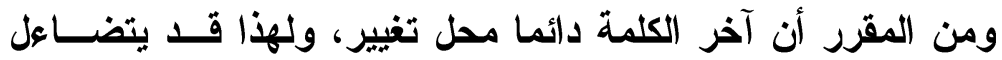

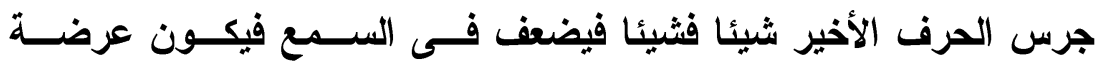

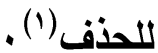

وقد مال بعض العرب إلى تقصير الحركة الطويلة فكانوا يقولون يوم

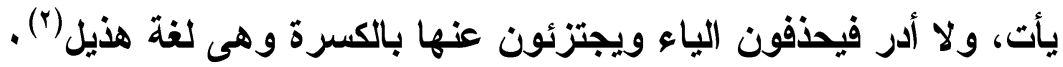

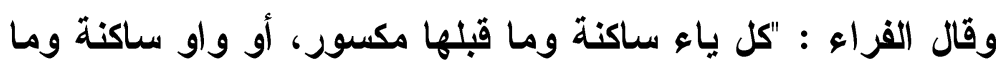

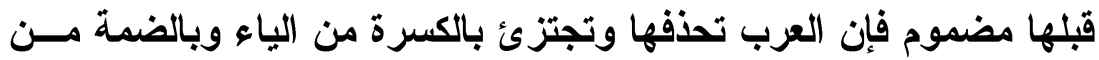

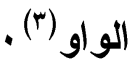

كما ذكر الفراء أن هوازن وعليا قيس يجتزئون بالضــم عـن واو

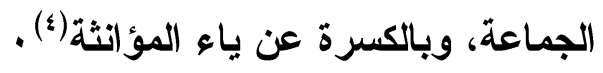

ونص سيبويه على ذلك وعز اه إلى ناس كثيرين من قيس وأسد (ه) .

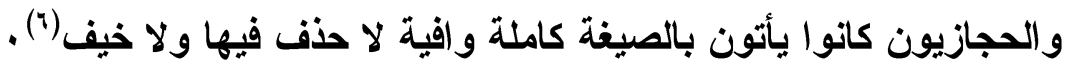

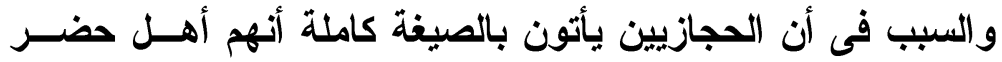

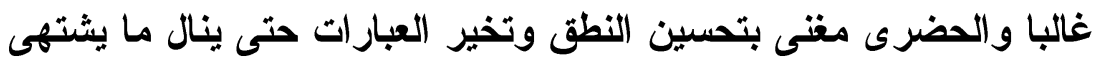

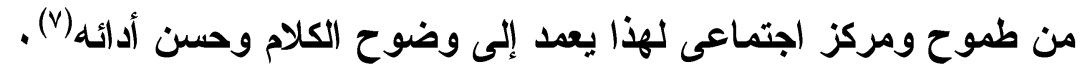

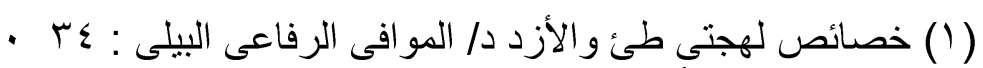

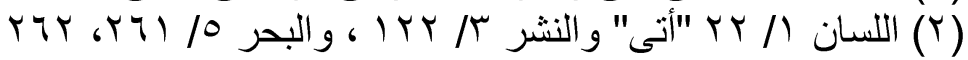
• ماد (Y)

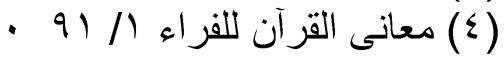

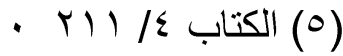

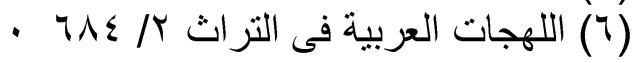

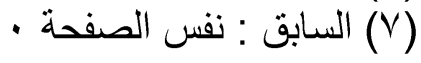


وقد جاء فى كتاب الحجة كلمتان حذفت فيهما الياء واجتزئ عنها بالكسرة، وعزى ذلك إلى اختلاف اللهجات، وهات التان الكلمتان هما:

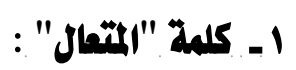

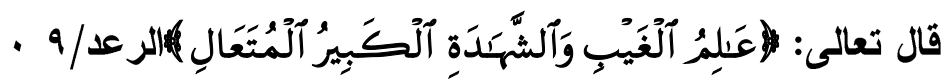

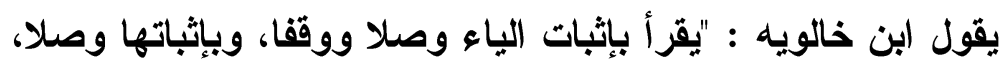

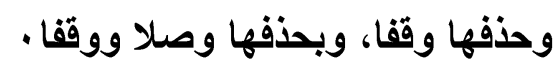

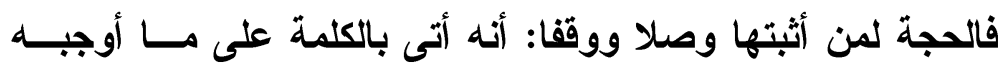

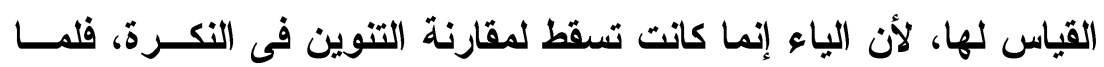

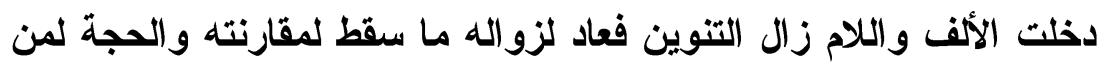

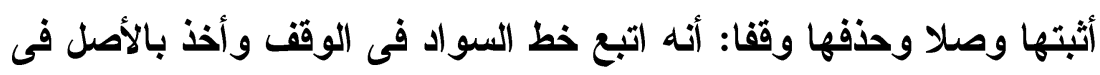
الوصل، فأنى بالوجهين معا .

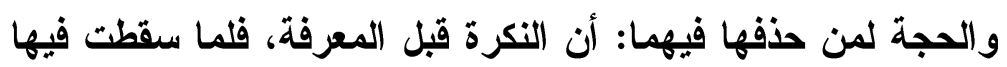

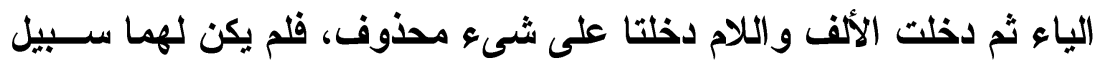

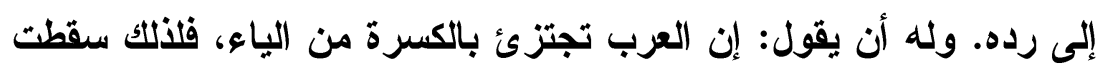

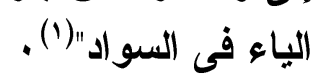
وعزيت القراءة بالياء فى الوصل والوقف إلى ابــن كثيــر وكــلتك

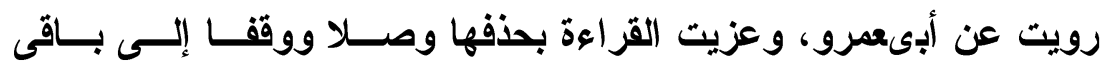

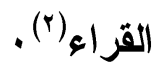

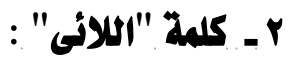

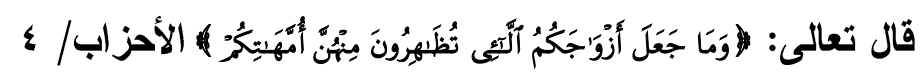

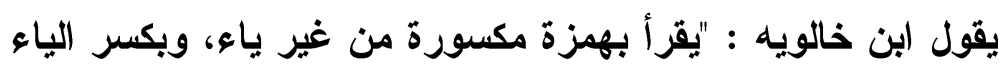

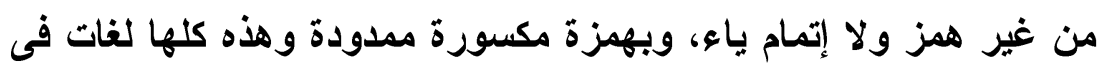

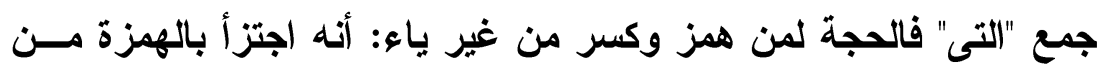

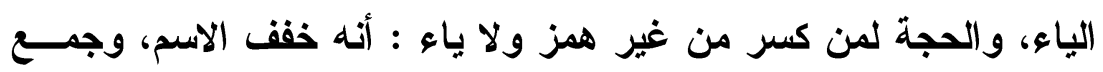

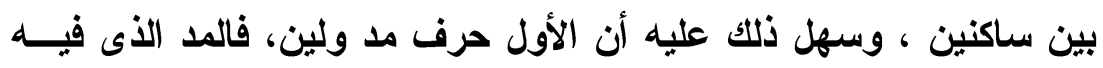

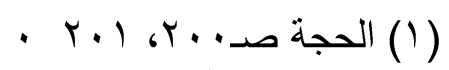

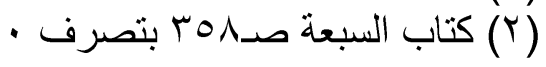


يقوم مقام الحركة، والحجة لمن همز ومد: أنه أتى بالكلمة على أصل مـــ

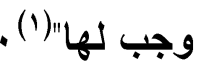

وعزيت القراعة بكسر الهمز وحذف الياء إلى ابن كثير ونافع ، وقــرأ

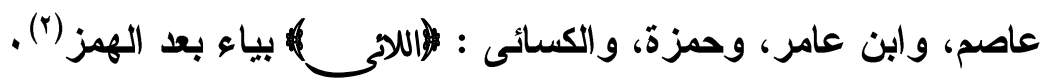

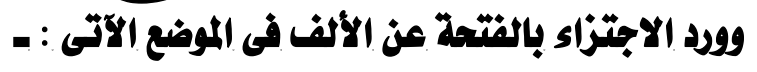

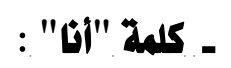

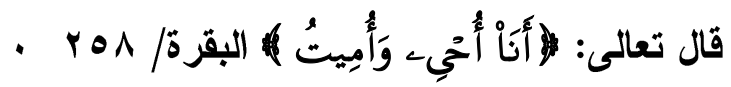

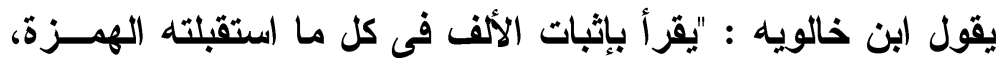

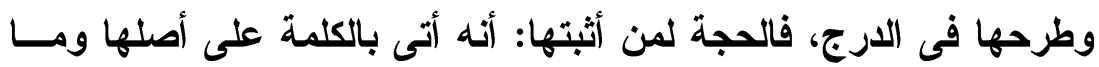

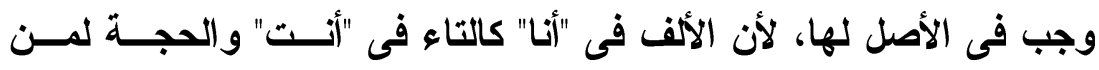

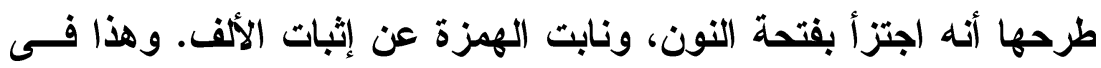

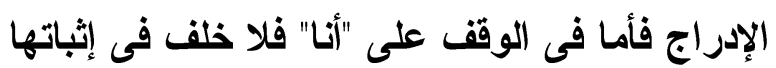

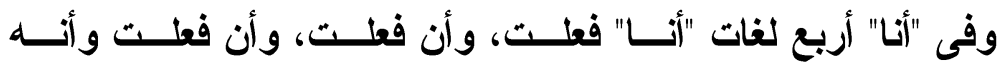
فملت (r) (

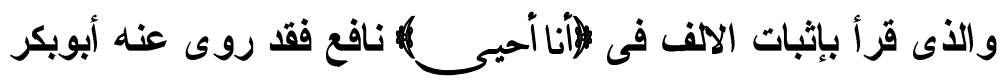

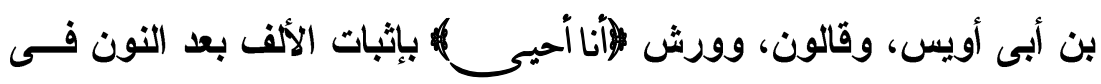

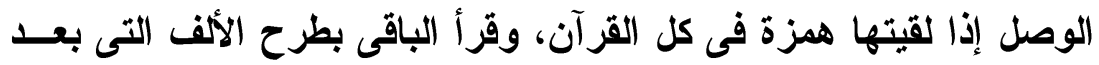

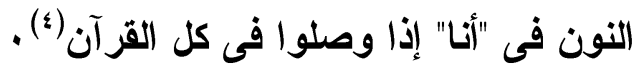

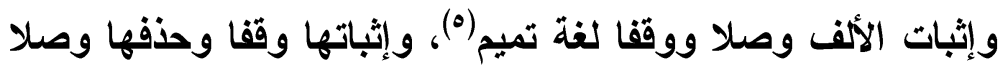

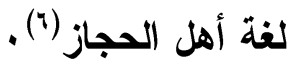

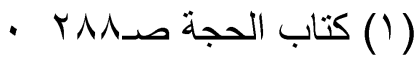

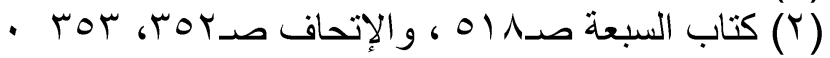

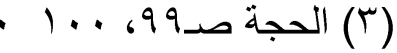

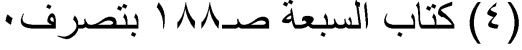

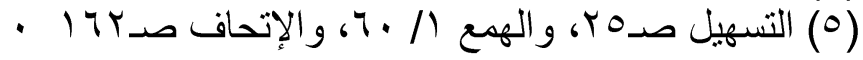

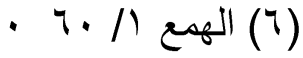


ومن العرب من يقول أنه فى "أنا" إذا وقف وهى لغة جيدة وهى فى عليا تميم وسفلى قيس (1) .

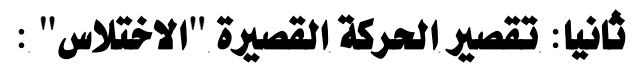

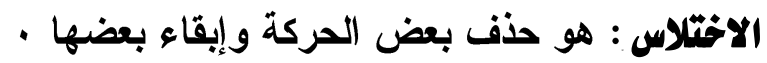

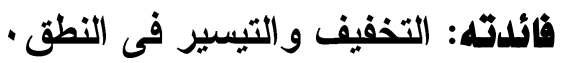

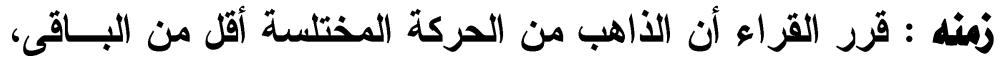

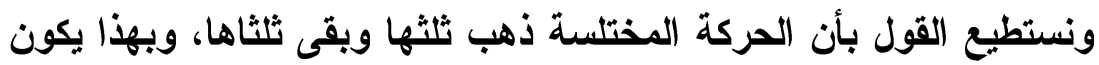

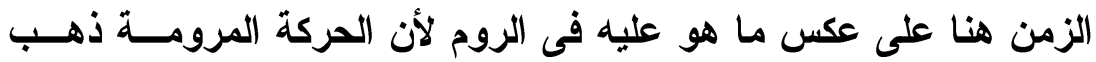

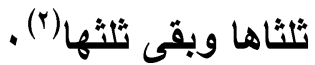
وهذا الاختلاف بين الروم والاختلاس قد أثثار إليه البناء إذ يقهــول:

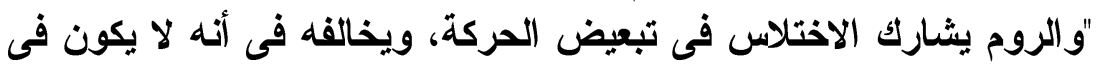

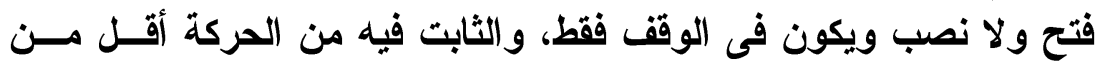

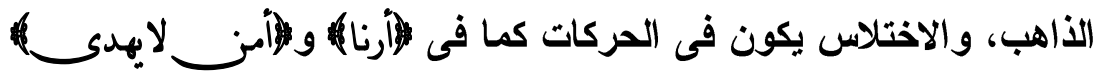

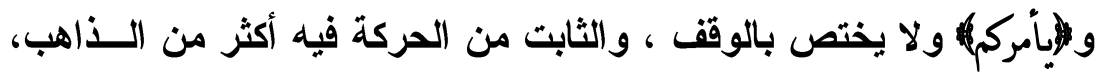

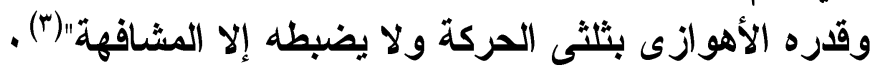

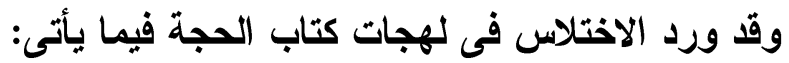

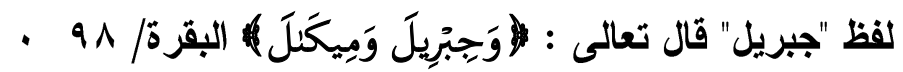

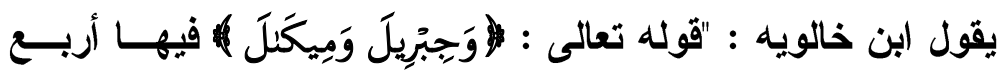

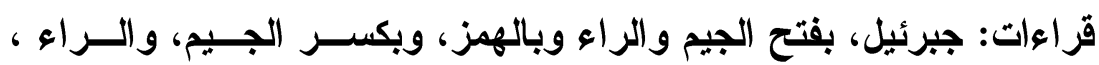

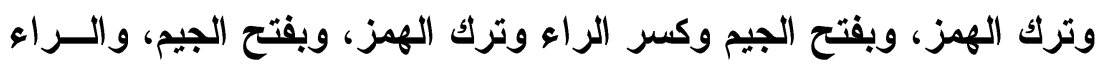

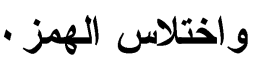
و وميكال) يقرأ بالمد و الهمز، وبالألف من غير مد ولا همز، وبالهمز

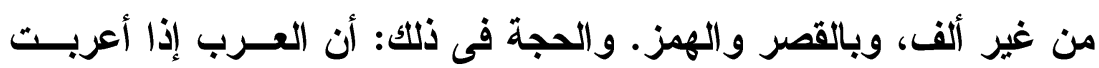

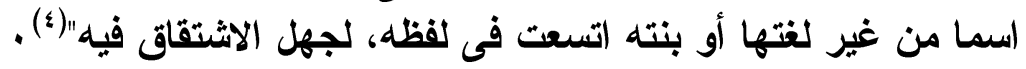

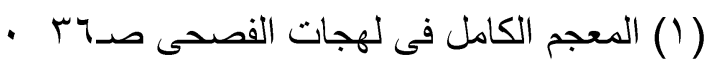

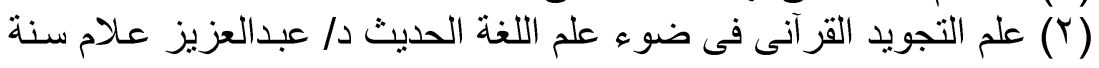

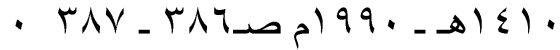


قرأ (بن كثير: "وجبريل بفتح الجيم وكسر الراء مــن غيـر هــــ،

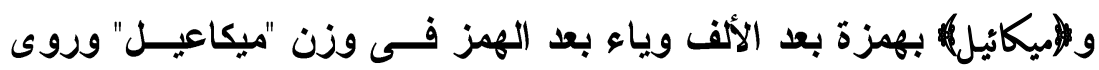

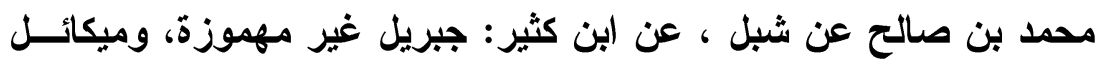

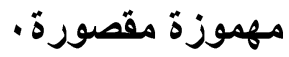
وقرأ نافع : الجبريل) بكسر الجيم والراء من غير همز مثل أبىعمرو

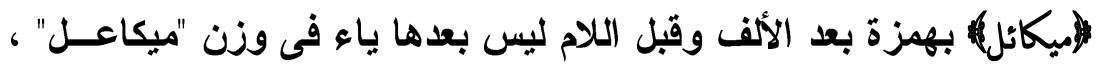

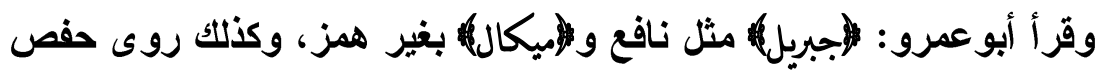

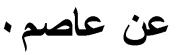

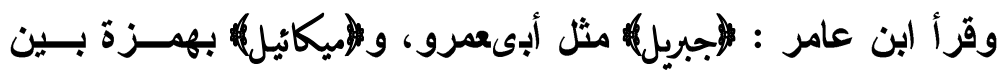
الألف و الياء الممدودة . وقر أ عاصم فى رواية يحيى بن آدم عن أبىبكر - وحماد بن سلمة

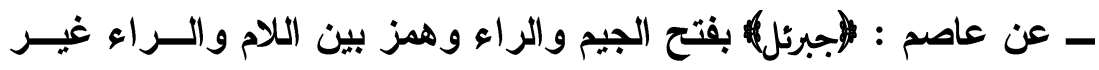

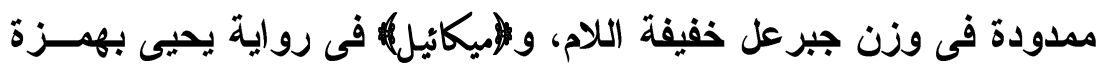

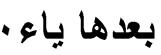
وقر أ حمزة و الكسائى : (لجبرئيل) و وميكيل) ممدودين بهمزة بعـدها

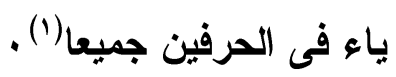

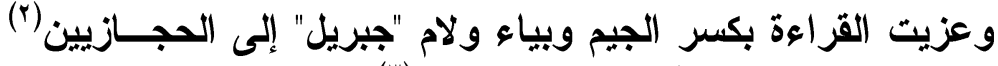
ولغة تميم وقيس وكثير من أهل نجد : جبر ائيل (r) .

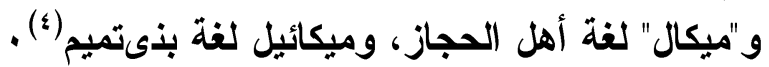

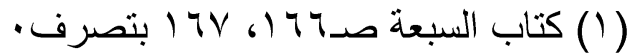

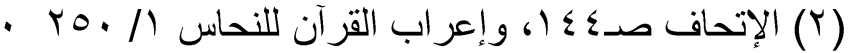

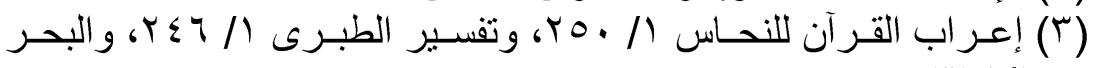
- $T / N$

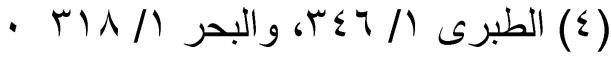




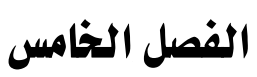 \\ الحذف الحفان

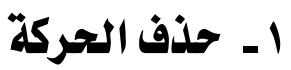

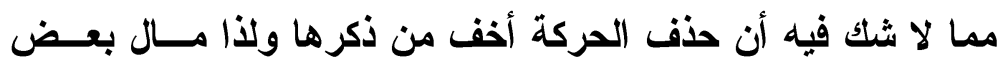

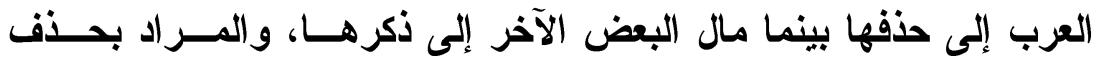

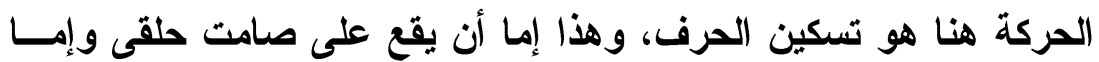

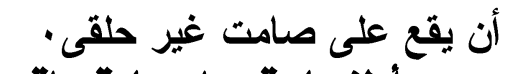
أولا: ما يقع على صامت حلقى:

أ ـ. حلف ما توالت فيه ضمتان: وقد فئ ورد هذا في الكلمات الآتية:

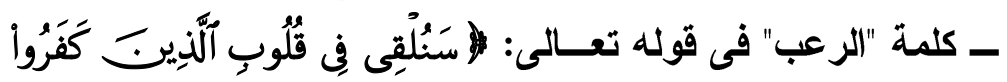

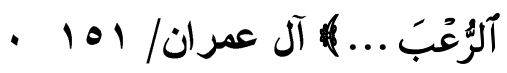

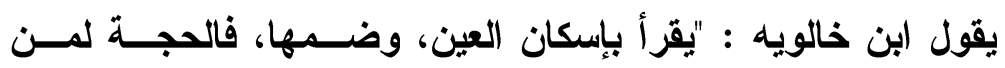

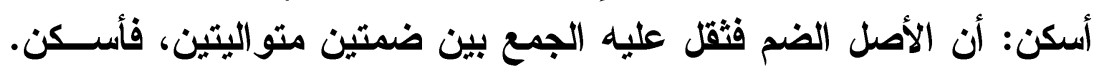

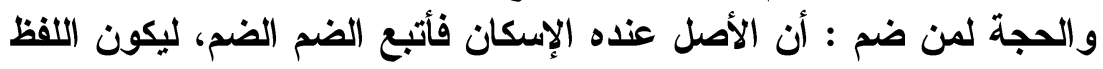

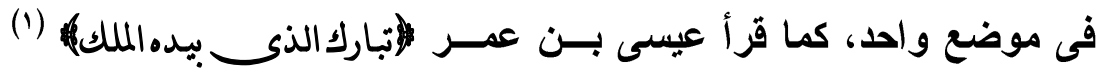

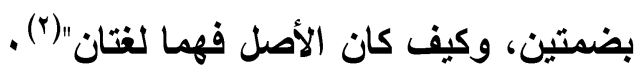

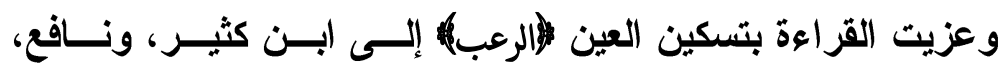

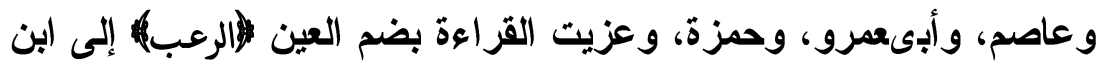

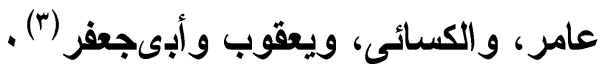

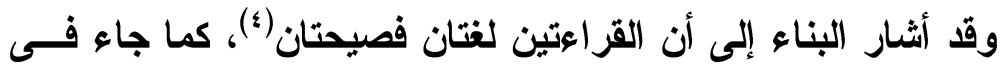

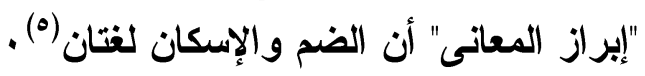

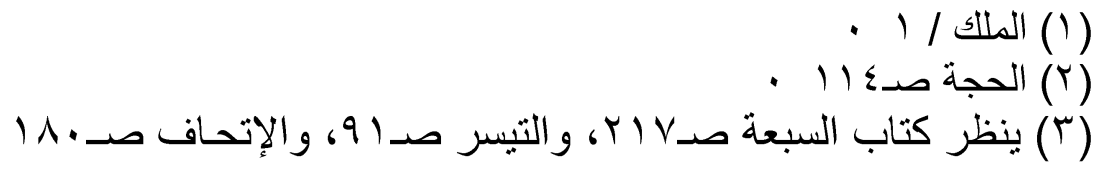

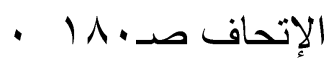

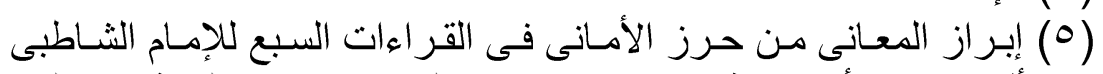

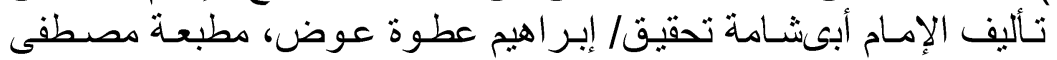

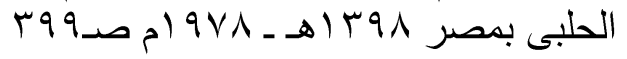


وذكر العلماء أن بعض العرب يميلون إلى إسكان العين فــى بنــاء

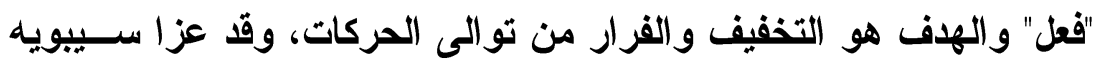
ذلك إلى تميم، ويكر بن وائل (1) .

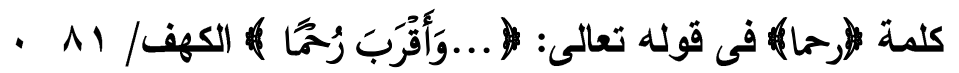
يقول ابن خالويه : "يقرأ بضم الحاء و إسكانها، وهما لغتان: كالعمر

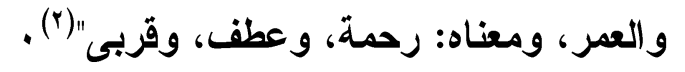

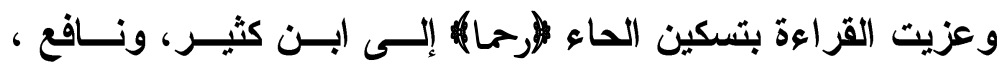
وعاصم، وحمزة، والكسائى، وعزيت القراءة بضم الحاء (لرحما) إلى (بـن

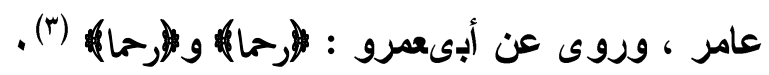

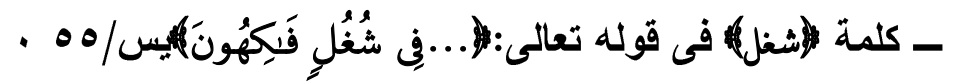

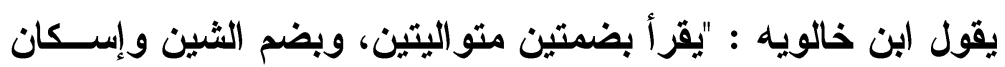

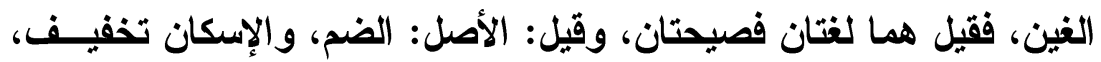
وقيل معنى شغلهم : افتضاض الأبكار، وقيل: استماع النغم والألحان" (؛) .

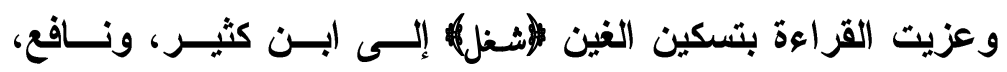

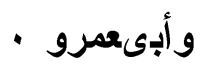
وعزيت (القراعة بضم الغين (ششغل) إلى عاصم، وابن عامر، وحمزة، و الكسائى (0).

ومن قرأ بتسكين الغين ثقل عليه توالى ضـــتين فأســــها تخفيفــا

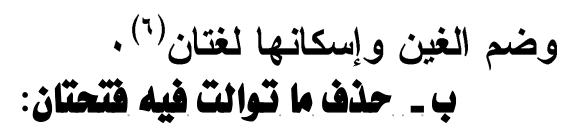

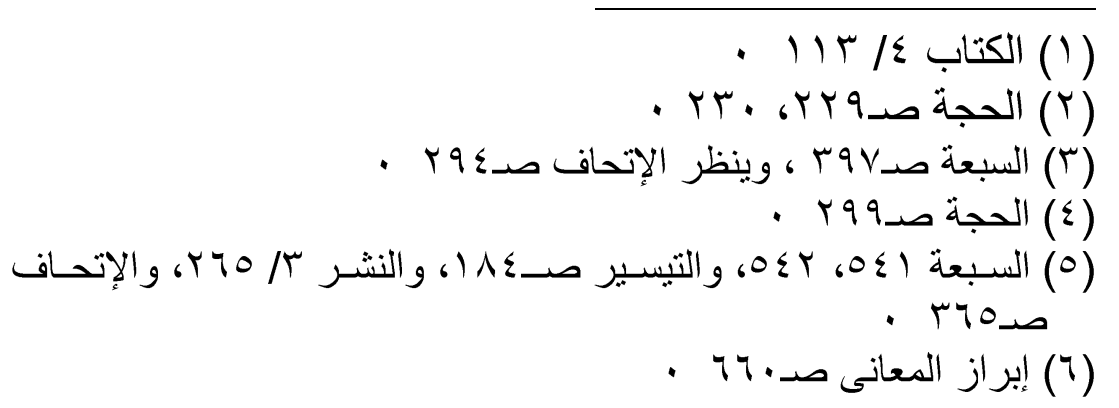


ذكر ابن جنى أن عامة عقيل من القبائل التى كانت تقــــأ الصــامت

الحلقى بالفتحة إذ يقول معلقا على قراعة سهل بن شعلى شعيب "جهره وزهره" :

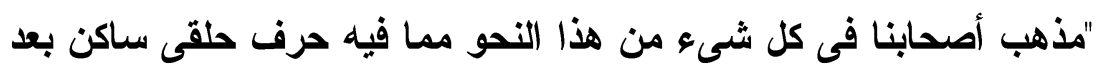

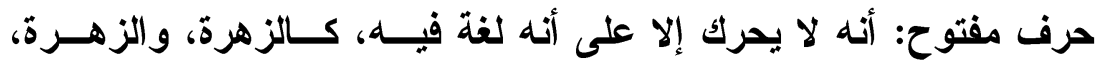

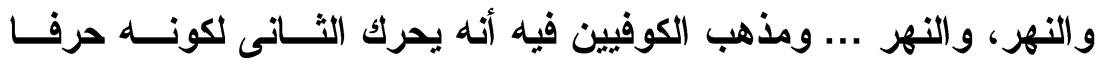

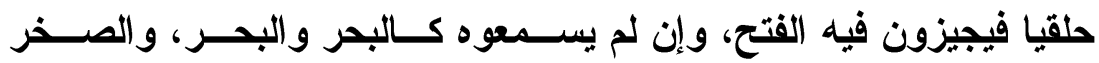

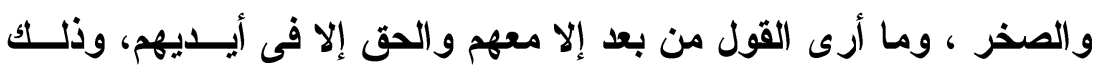
أننى سمعت عامة عقيل تقول ذالك (')" . وقد ورد حذف ما توالت فيه الفتحتان فى الكلمات الآتية:

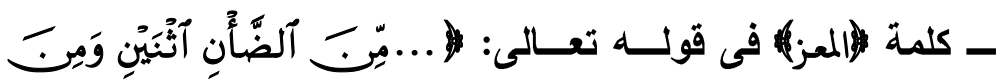

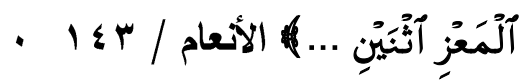
يقول ابن خالويه : "يقرأ بفتح العين وإسكانها، وهما لغتان، والأصل الإسكان، وإنما جاز الفتح فيه، لمكان الحرف الحلقى"(†) .

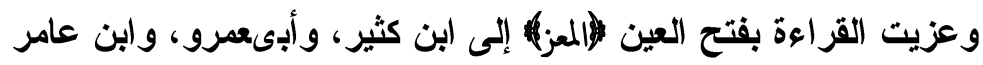
وعزيت القراعة بتسكين العين (المعز) إلى عاصم، ونــافع، وحمـزة و الكسائى (r) .

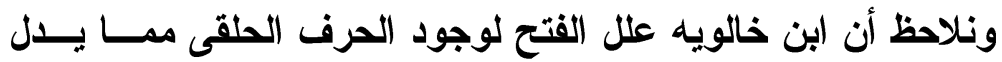

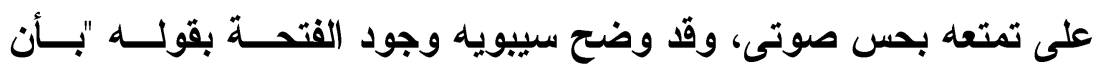

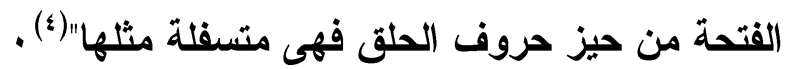

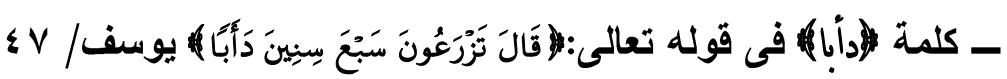

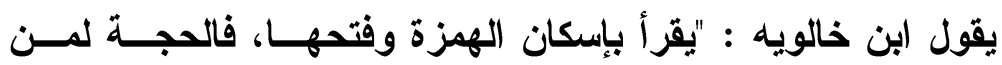

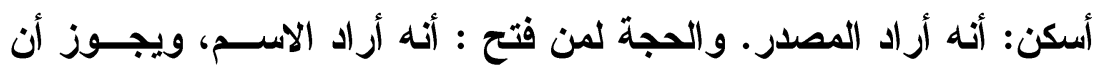

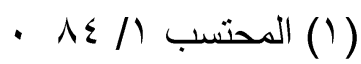

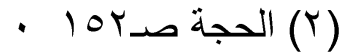

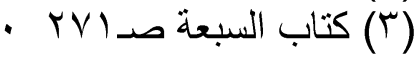

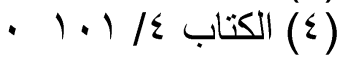


يكون أصله الفتح، فأسكن تخفيفا، والعرب تستعمل ذلك فيما كـان ثانيـهـ

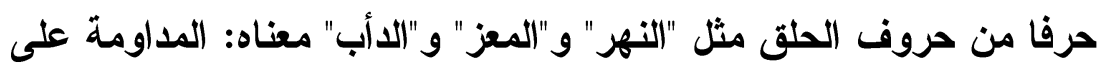
الثىء وملازمته، والعادة قال الكميت:

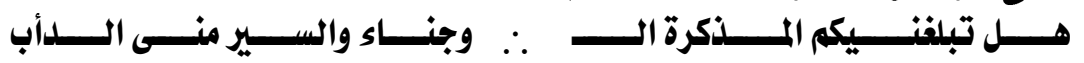

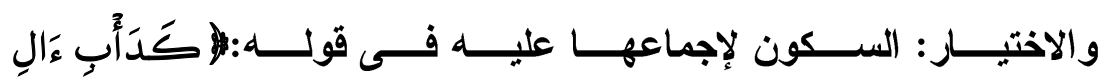

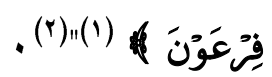

وعزيت القراعة بتسكين الهمزة (لوأبا) إلــى (بــن كثيــر، ونــافع، وأبىعمرو، وابن عامر، وحمة، والكسائى، وأبىبكر عن عاصم، وعزيت

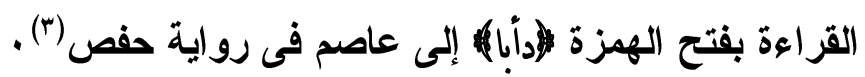

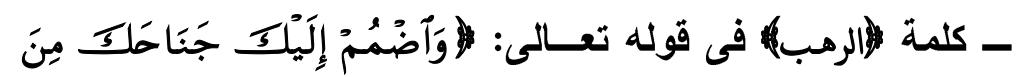

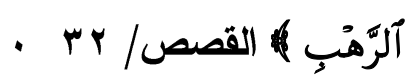

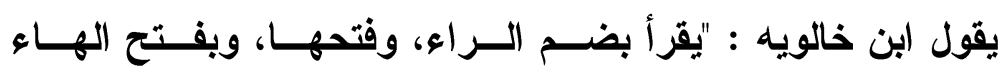

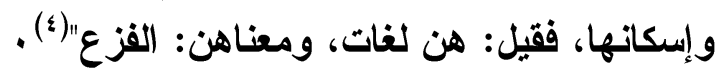

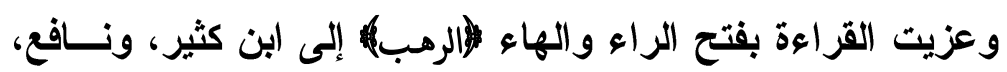

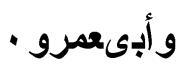
وعزيت القراعة بضم الراء وتسكين الهاء (الرهب) إلى (بن عـامر وحمزة ، والكسائى، وروى عمرو بن الصباح عن حفص عـن عاصــم :

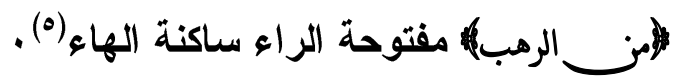

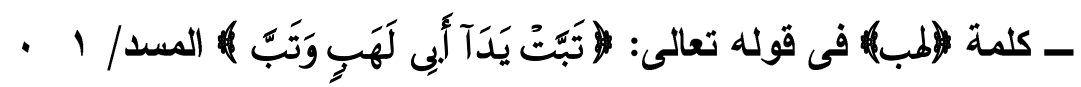




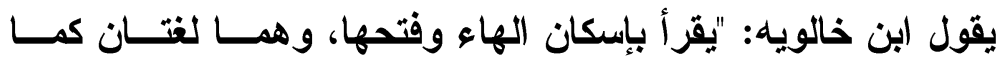

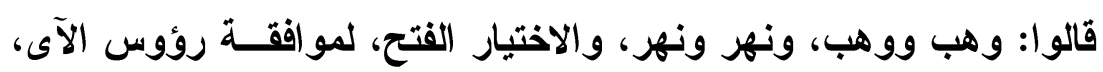

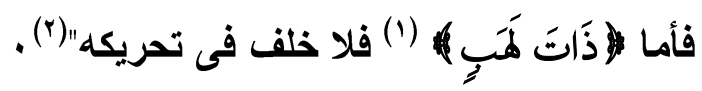

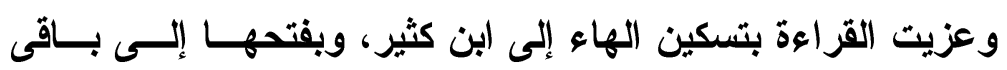

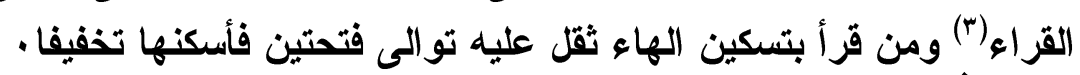

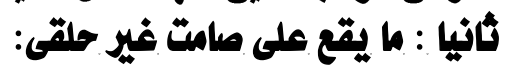

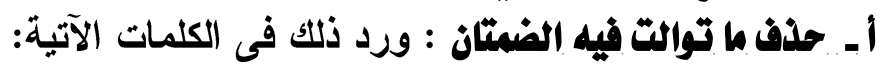

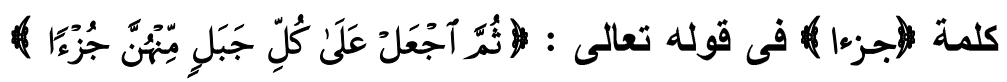

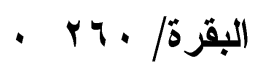

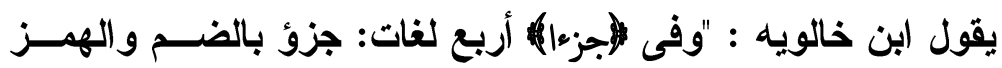

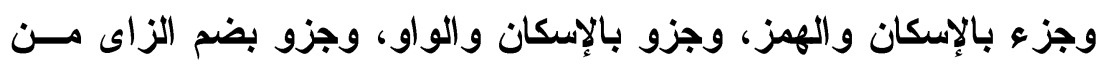

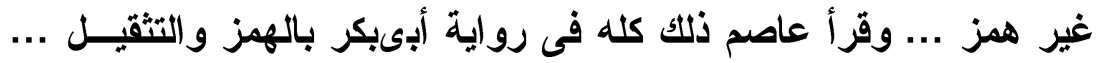

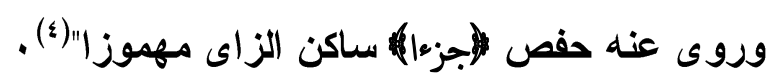

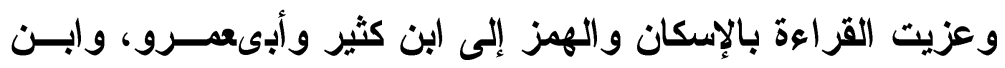

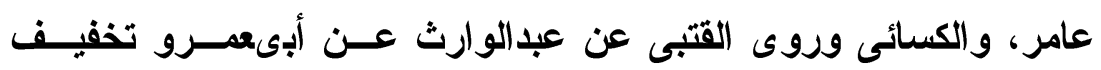

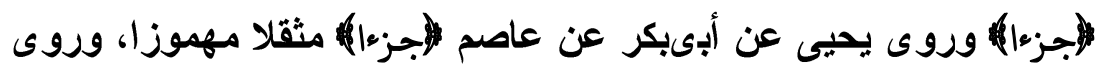

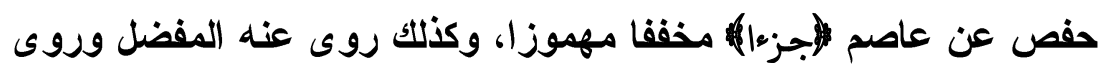

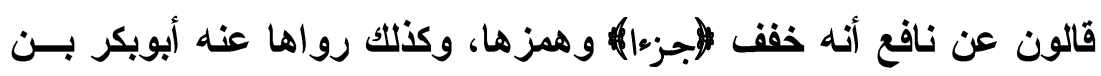

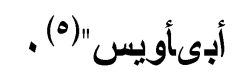

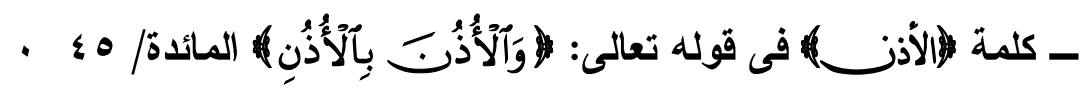

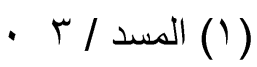

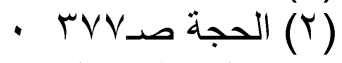

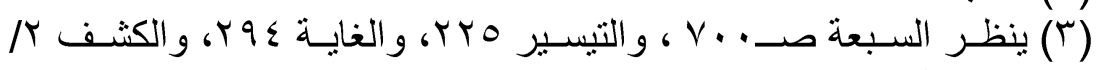

$$
\begin{aligned}
& \text { - }
\end{aligned}
$$

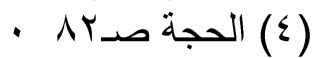

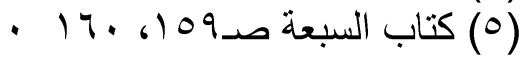


يقول ابن خالويه : "يقرأ بضم الذال، وإسكانها، فالحجة لمن ضـــ:

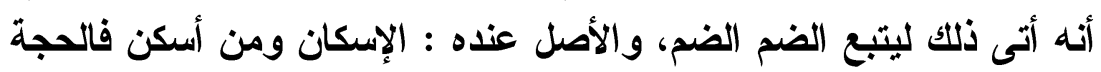

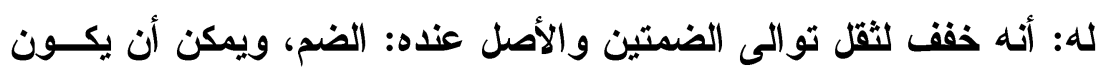

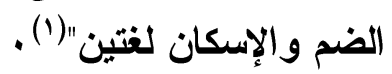

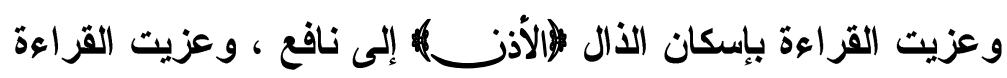

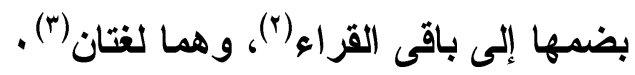

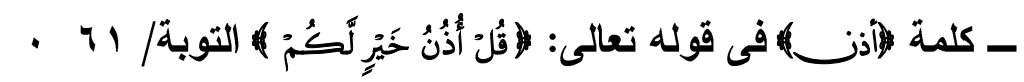

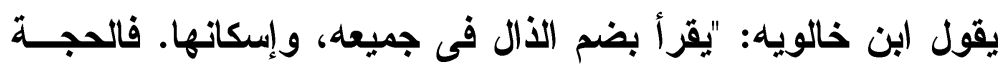

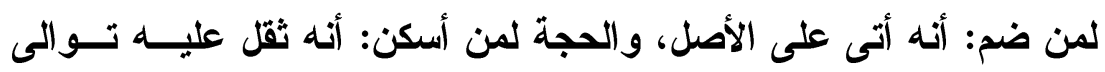

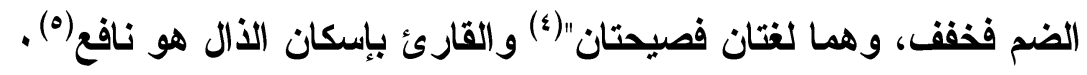

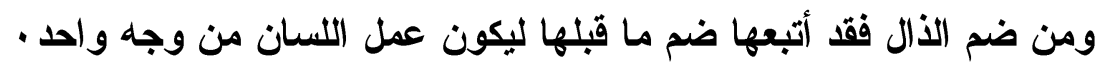

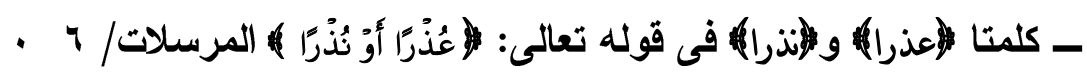

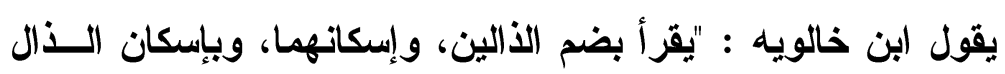

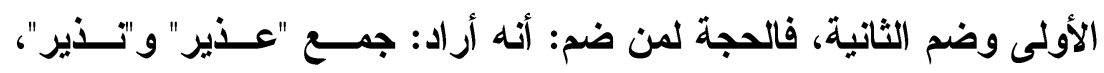

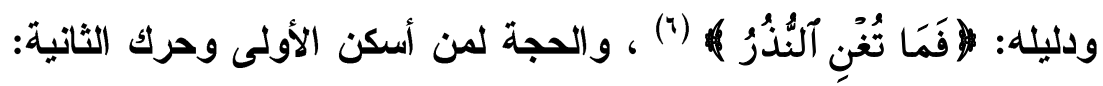

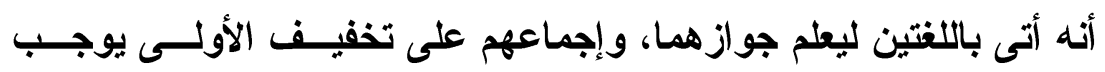

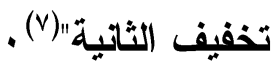

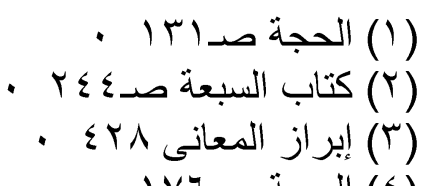

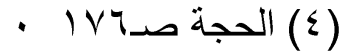

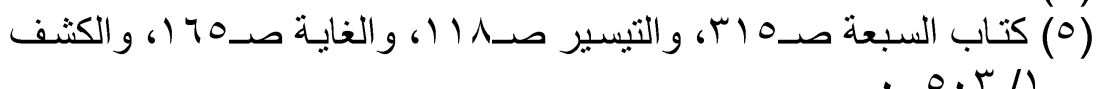
.

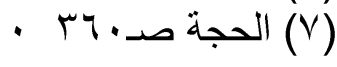




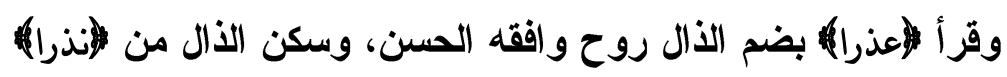

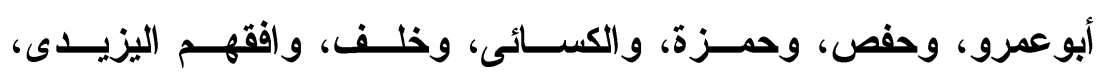

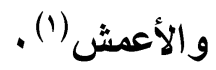

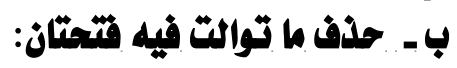

ورد ذلك فى الكلمة الآتية :

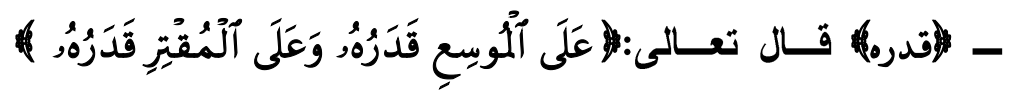

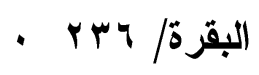

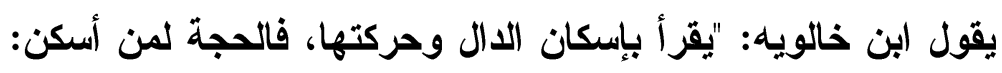

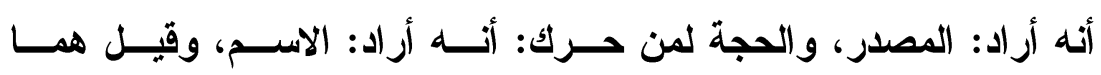

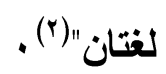

وعزيت القراعة بتحريك الدال (إقدره) إلى ابـن عـامر، وحمـزة ،

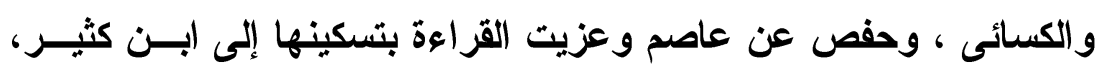

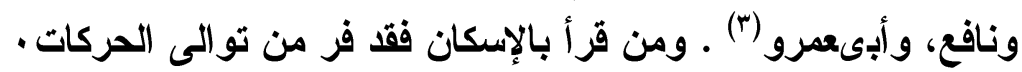

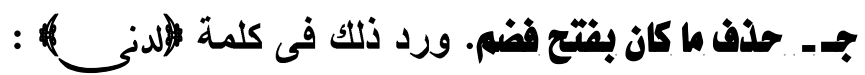

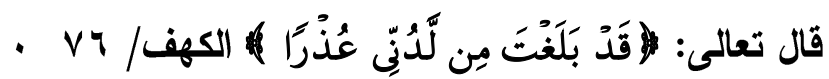

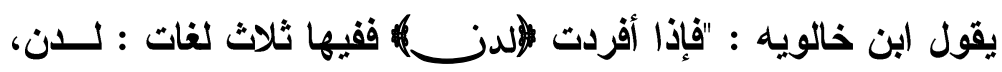

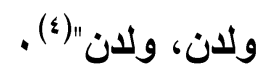

و "قال ابن برى: ذكر أبوعلى فى لان بالنون أربع لغات: لان ولان ، ولان

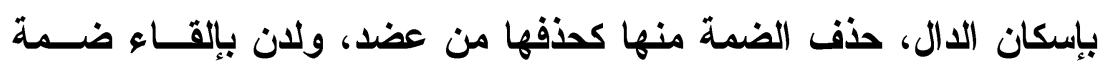

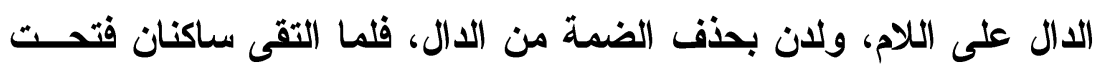

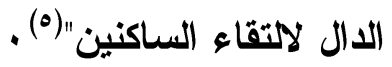

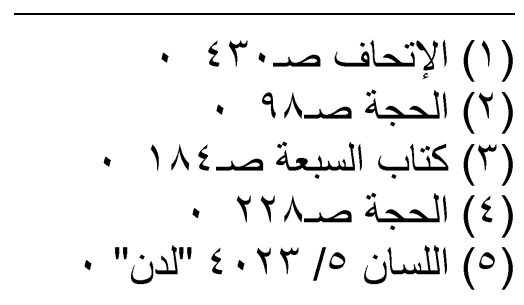




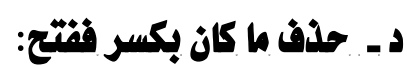

ورد حذف ما كان بكسر ففتح فى ياءات الإضافة وهى فى اصطى إطلاح

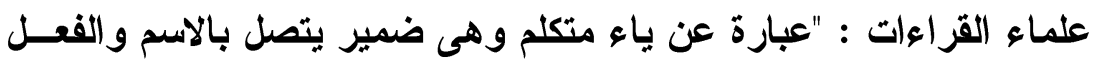

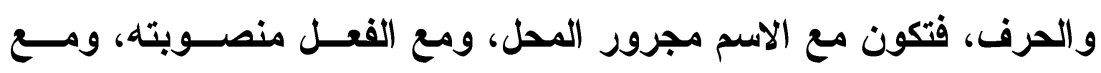

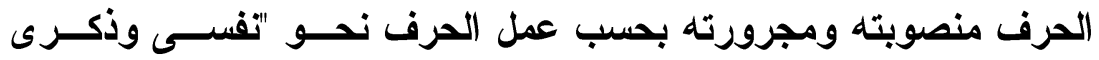

$$
\text { وفظرنى وليحزنتى وإنى ولى" (1) . }
$$

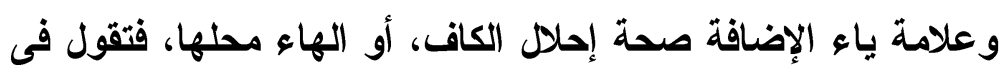
نحو: "فطرنى ، فطرك، وفطرة" (r) ).

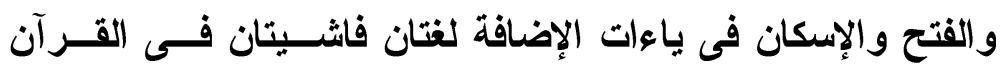

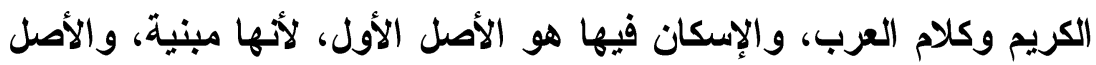

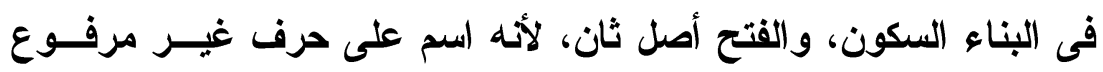
فقوى بالحركة وكاتت فتحة للتخفيف" ("ام) .

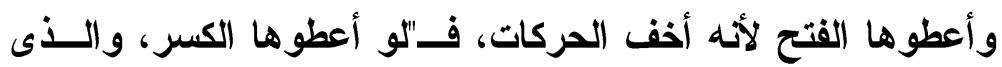

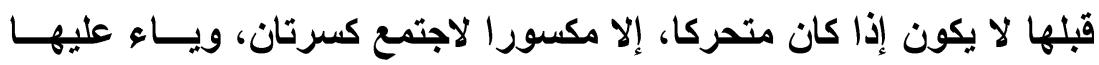

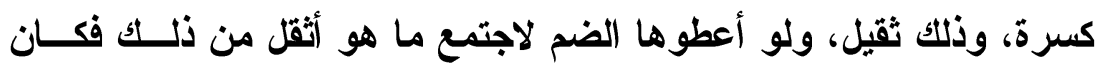

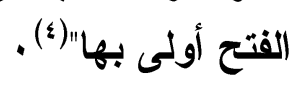
وقد نص ابن خالويه على الأوجه التى وردت عن العرب فى ياءات الإضافة فى الموضع التالى :

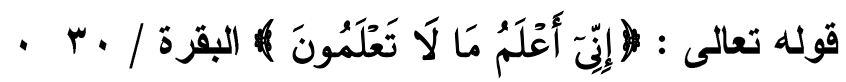

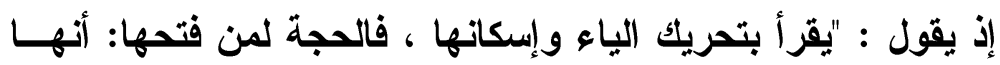

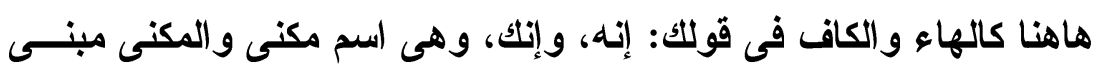

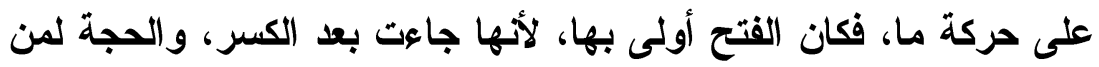

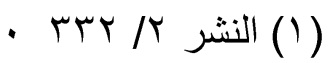

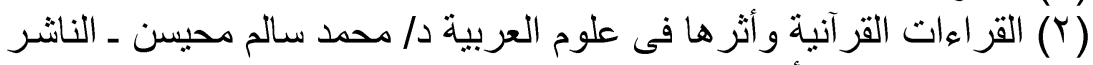

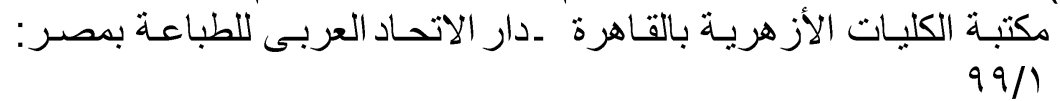


أسكن: أن يقول: الحركة على الياء ثقيلة وأصل البناء السكون، فأســنها تخفيفا .

و القزاء يختلفون فى هذه الياءات وما شـاكلها من يــاءات الإضـــافة

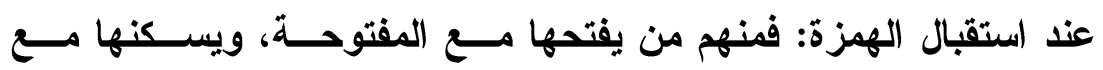

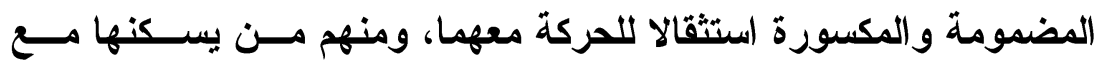

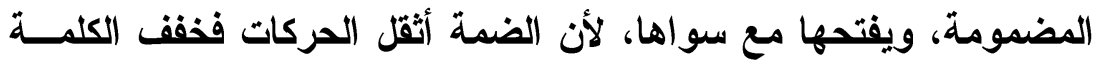

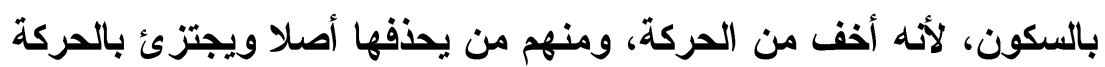
منها

فإن اتصلت بحرف واحد فالوجه فتحها لئلا تسقط لالتقاء السـاكنين

فتبقى الكلمة على حرف واحد، و إسكانها جائز -

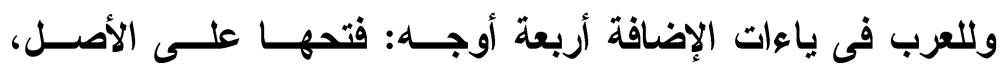

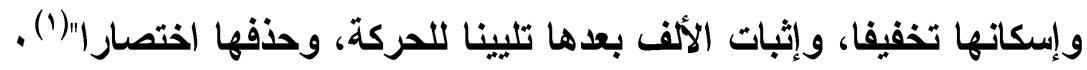

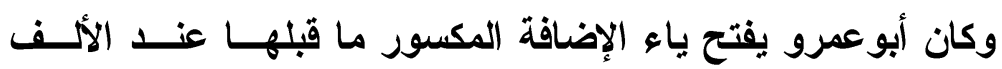

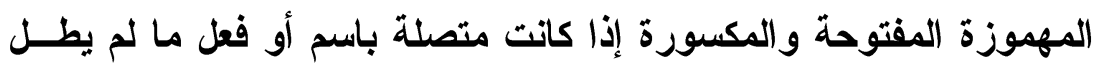

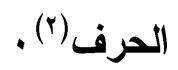

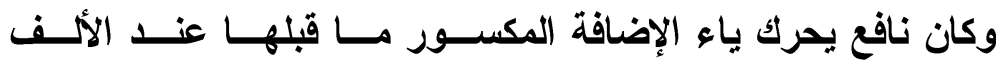

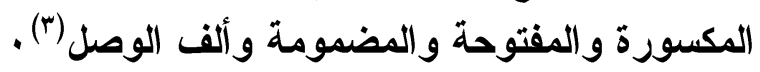

$$
\begin{aligned}
& \text { r - ـ حذف العرض : }
\end{aligned}
$$

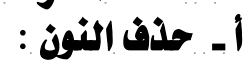

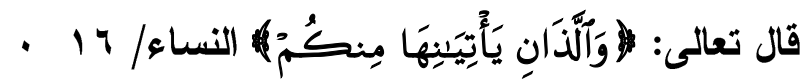

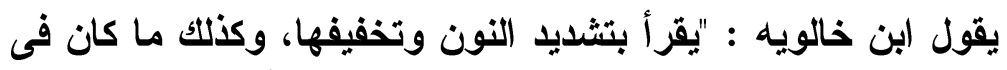

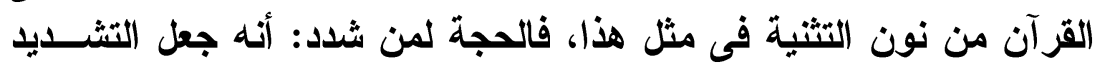

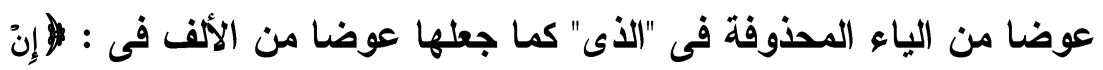


هَذَنِنِ َسَحِحرَنِِ ) (') ليفرق بين ما قد سقط منه حرف، وبين ما قد بنى على

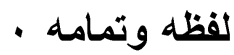

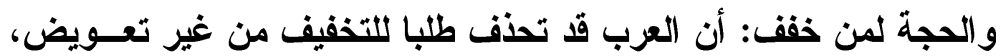

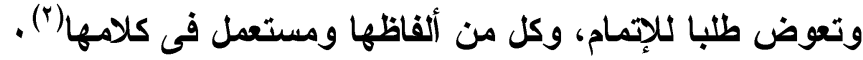

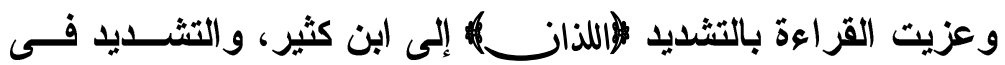

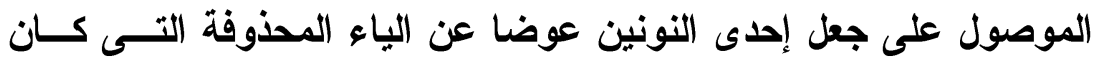

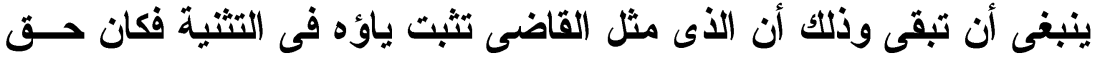

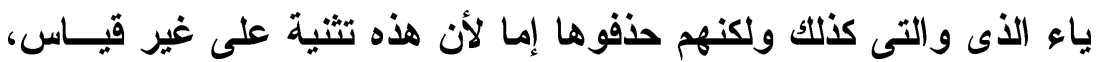

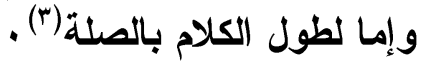

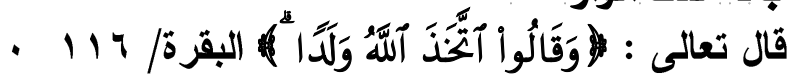

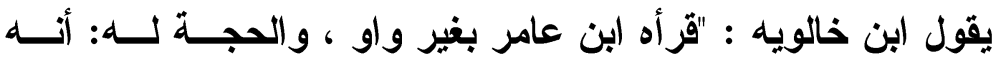

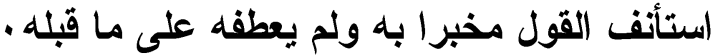

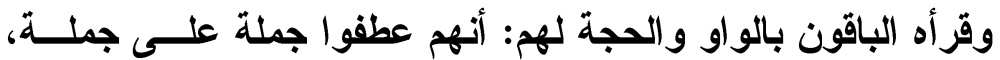

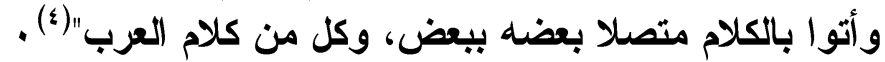

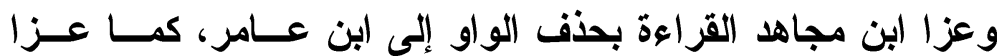
القراءة بإثباتها إلى باقى القراءع (ه) .

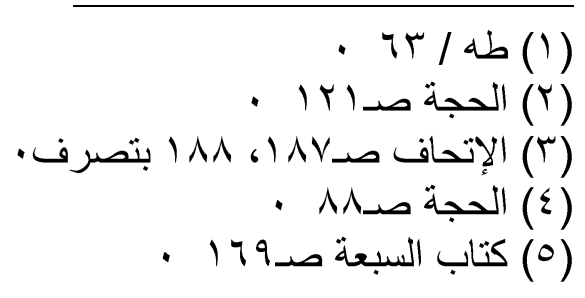




\section{الفمادل السادس المبرية \\ الظواهر الصرفية الطولية \\ أولا : البنية بين الطول والقصر : بوفية}

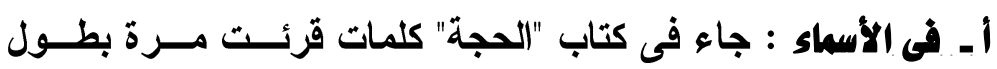

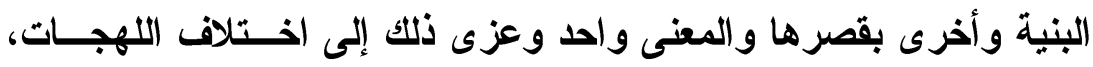

وتوضيح ذلك فى المواضع الآتية :

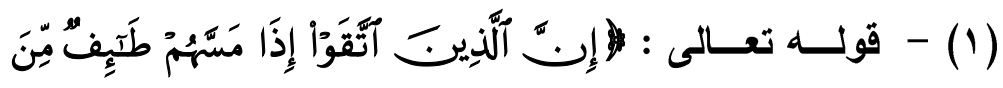

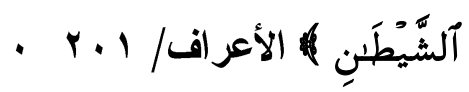

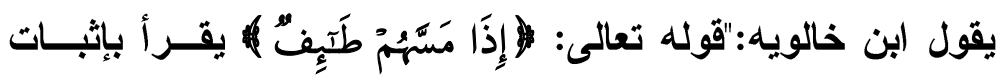

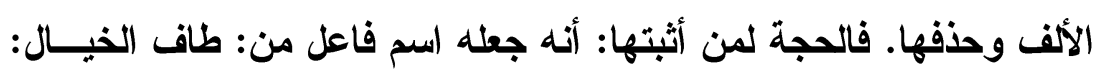

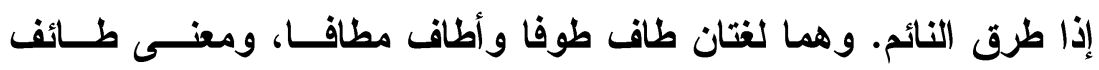

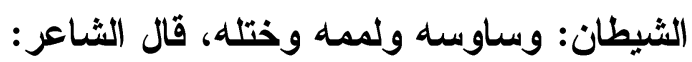

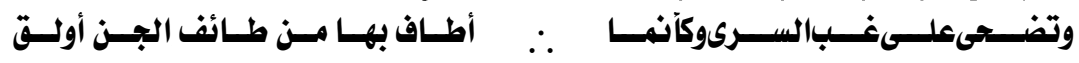

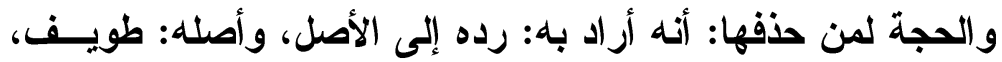

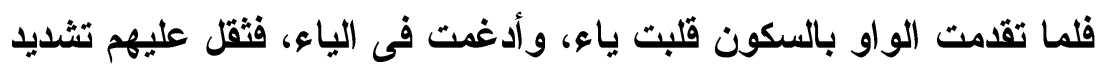

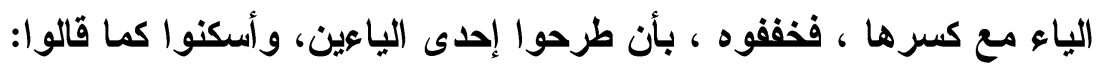

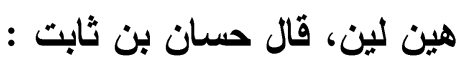

(1)

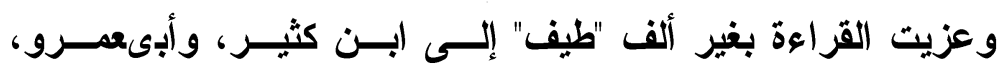

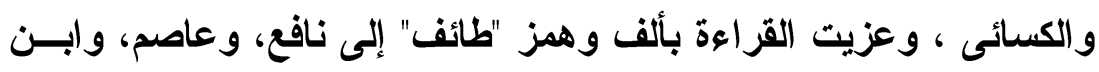

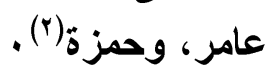

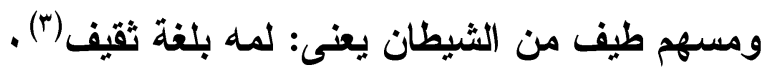

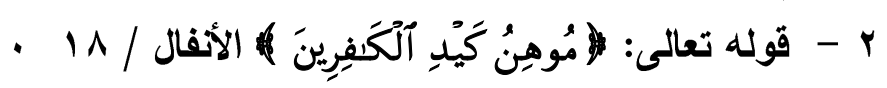

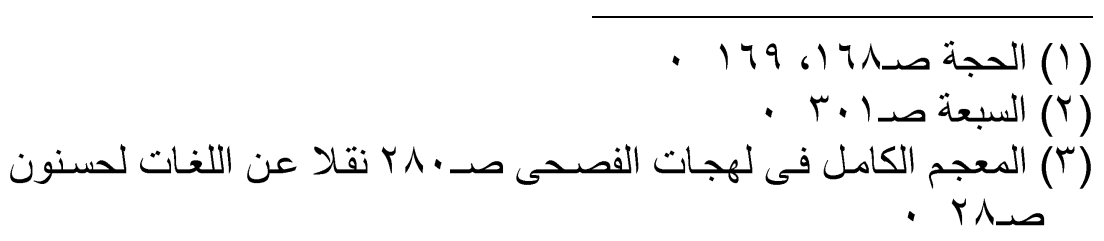




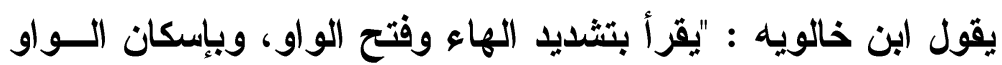

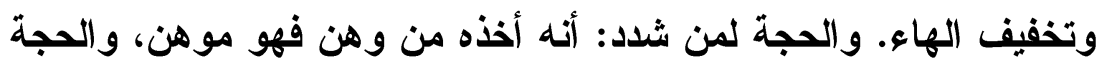

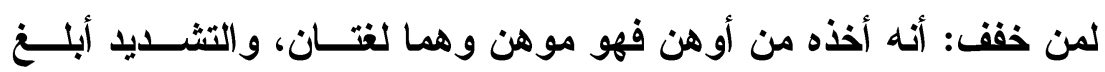

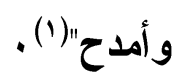

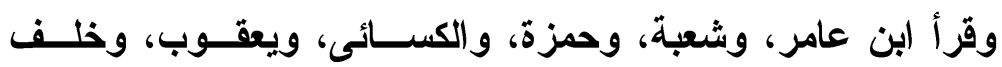

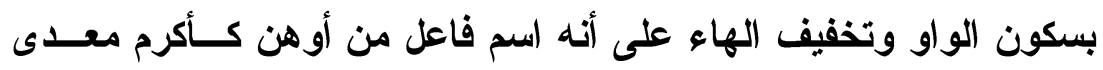

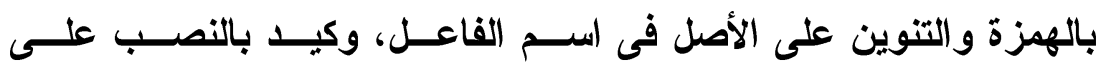

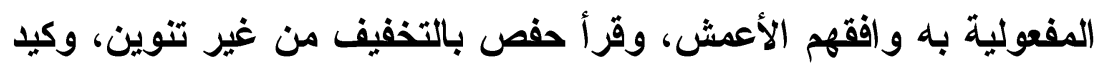

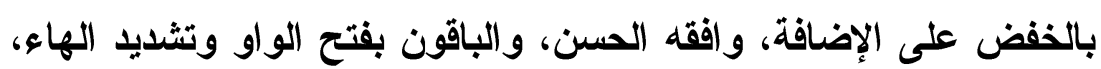

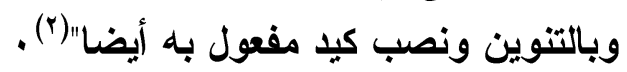

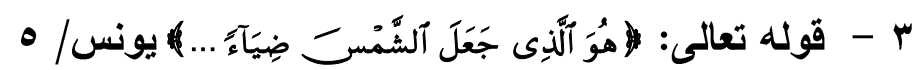

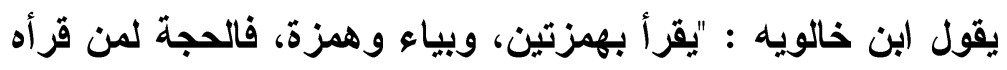

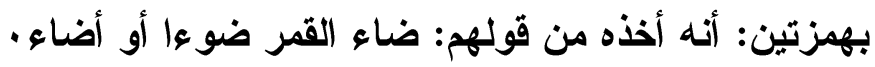

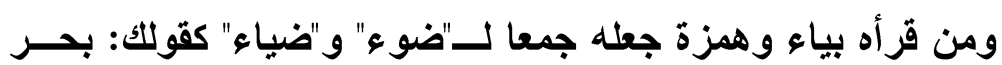

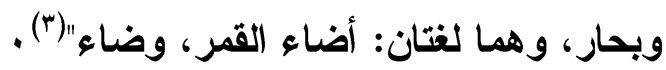
وعزيت القراعة بهمزتين "ضئاء" إلى ابن كثير، وقرأ الباقون بهمزة الفئرة واحدة"(i) . .

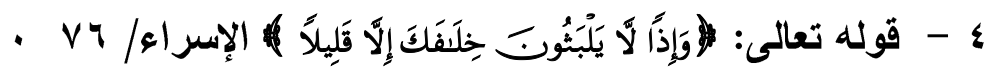

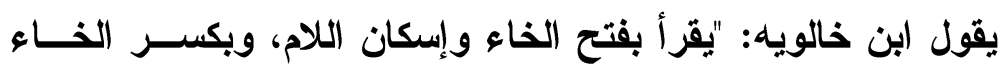

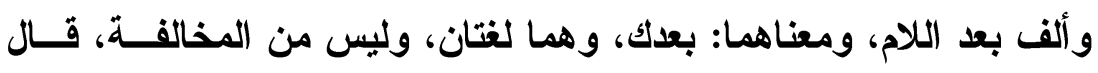

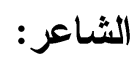

نــؤى أقــام خــلاف الحسى أو وتــــ(ه)

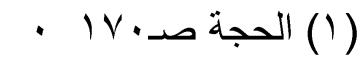

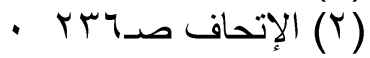

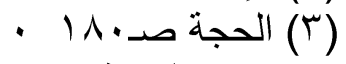

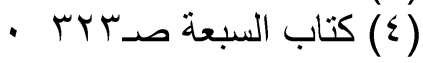

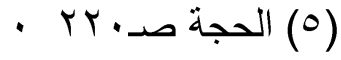




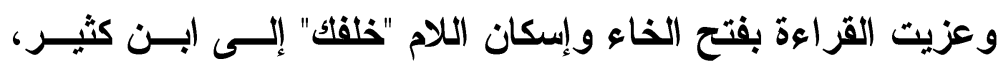

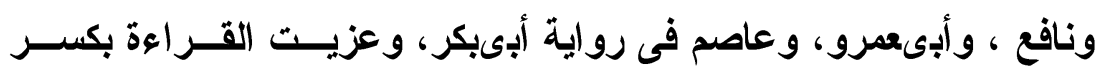

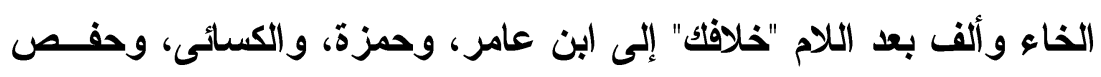

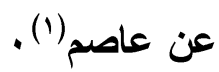

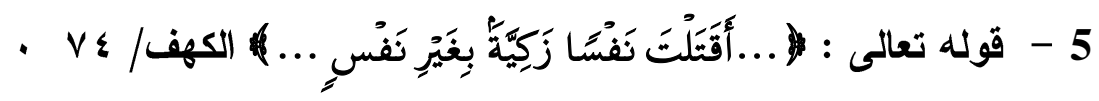

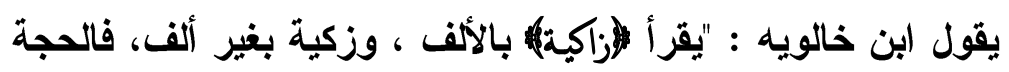

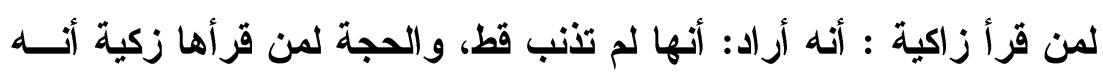

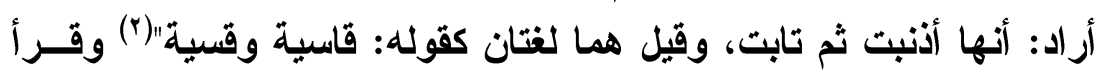

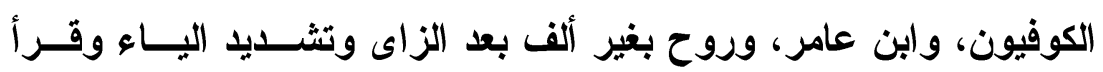

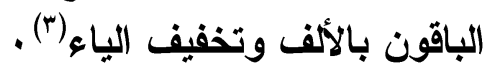

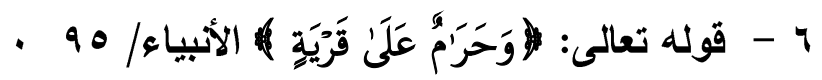

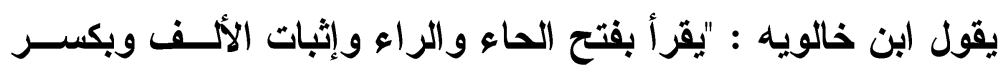
الحاء وإسكان الراء وحذف الألف، فالحجة لمن فتح وأثبت الثبت الألف أنه أراد:

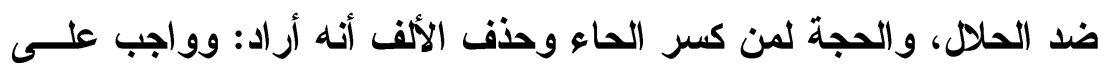

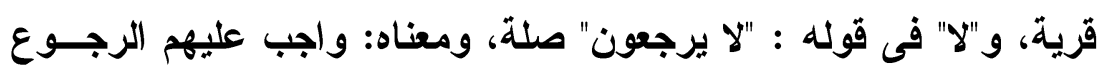

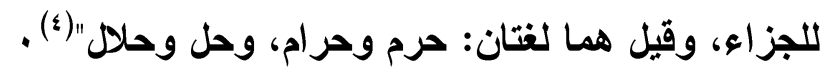

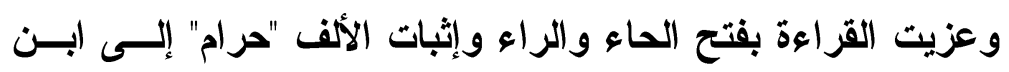

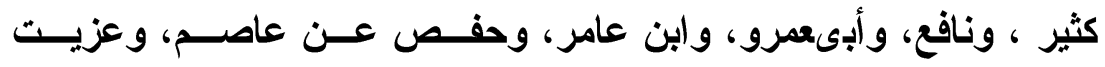

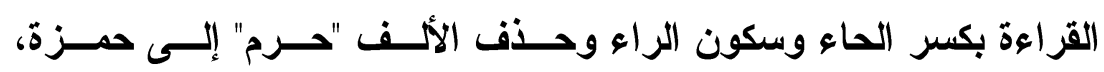

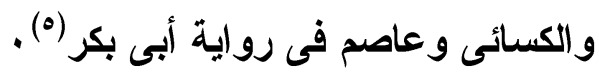

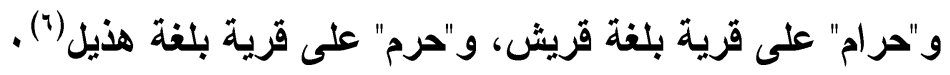

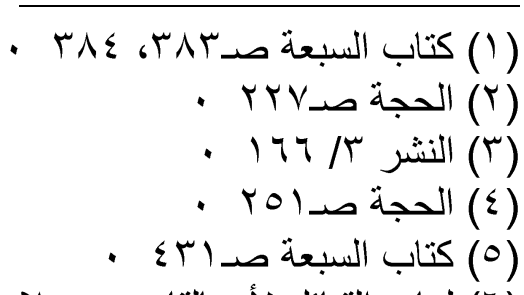

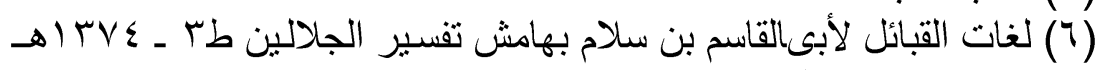

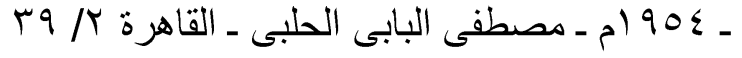




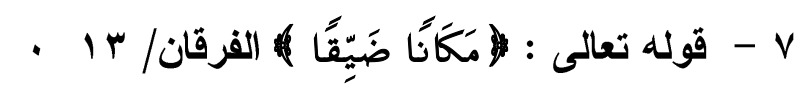

يقول ابن خالويه : "يقرأ بالتشديد والتخفيف فقيل: هما لغتان، وقيل

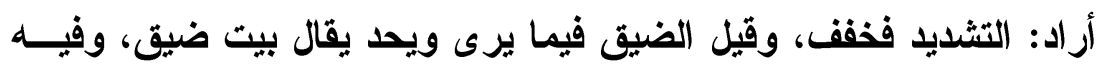

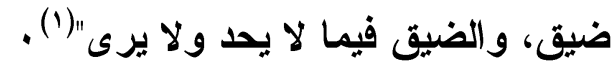
وعزيت القراءة بالتخفيف (اضضيقا) إلى ابن كثير ، وعزيت القـراءة

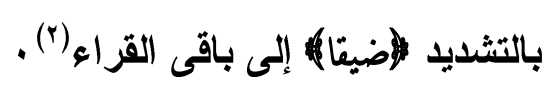

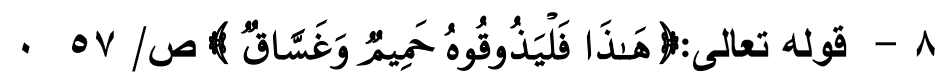

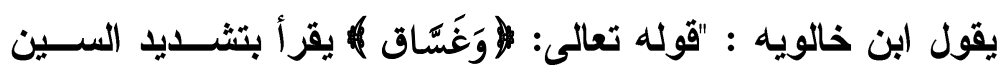

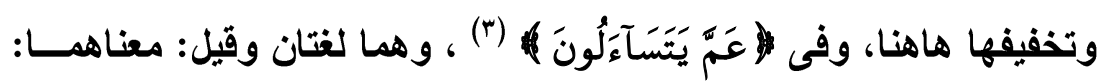

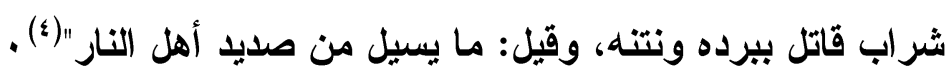

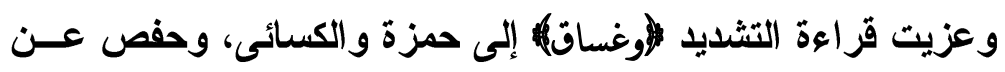

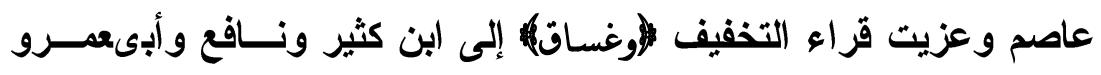

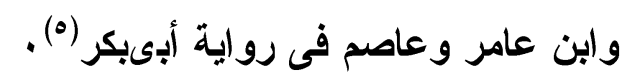

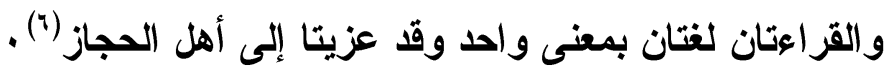

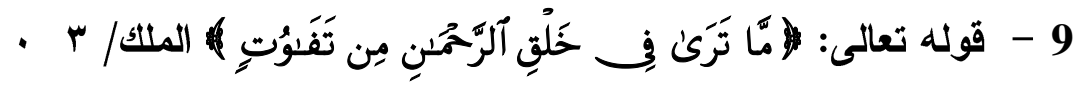

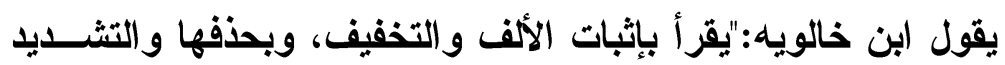

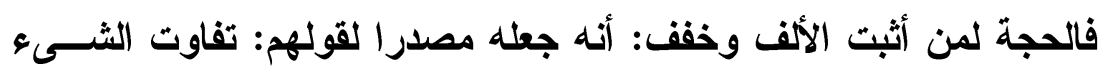

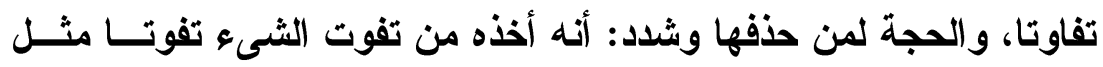

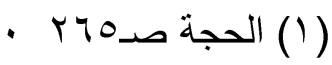

$$
\begin{aligned}
& \text { - TrV }
\end{aligned}
$$

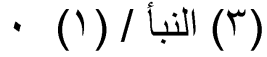

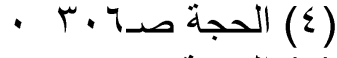

$$
\begin{aligned}
& \text { - }
\end{aligned}
$$

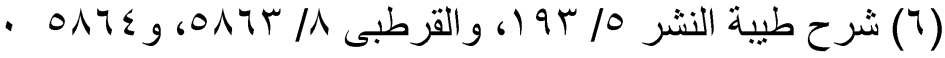




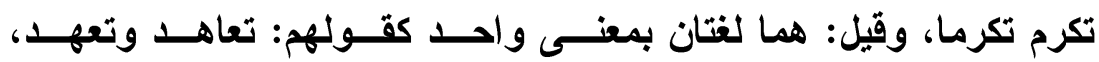

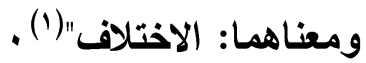

وعزيت القراعة بضم الواو مشددة (لتفوت) إلى حمــزة و الكســائى،

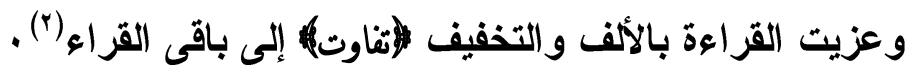

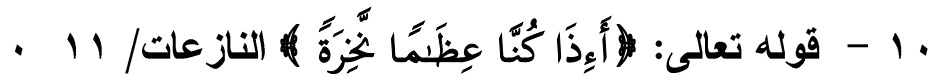

يقول ابن خالويه : "قوله تعالى: (زناخرة) يقرأ بإثبات الألف وحذفها،

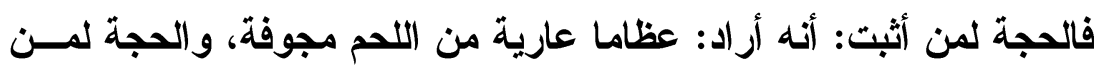

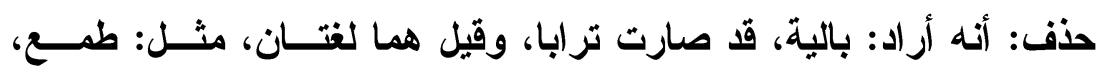

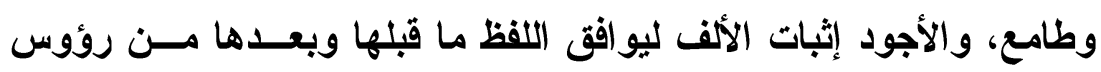

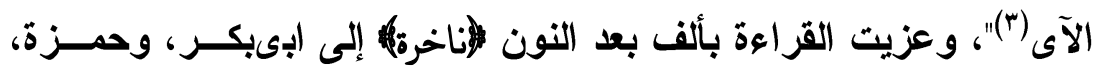

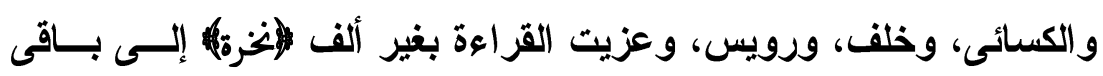

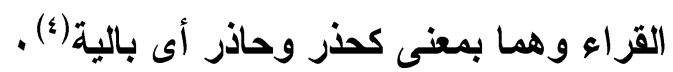

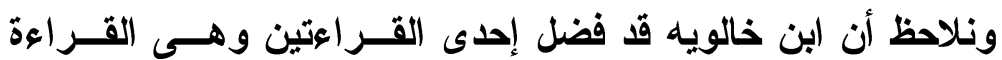

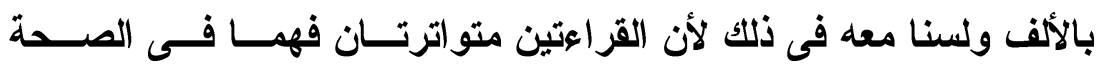

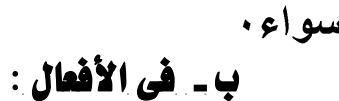

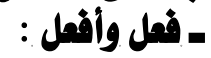

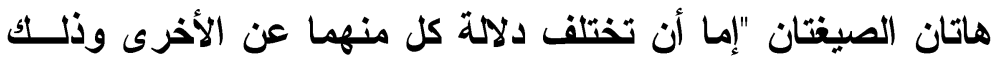

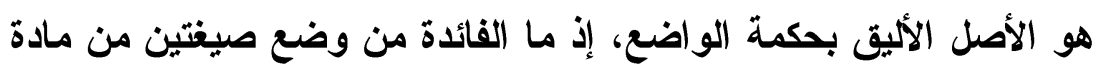

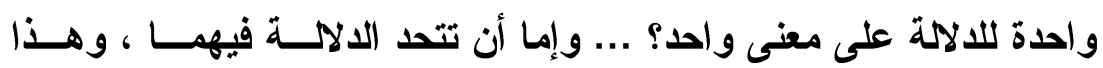

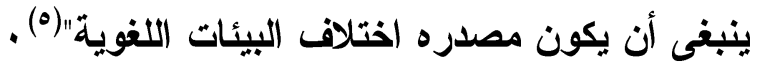

$$
\begin{aligned}
& \text { - (1) الحجة صدو (1) }
\end{aligned}
$$

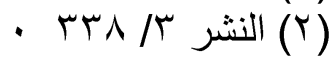

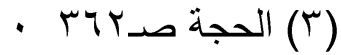

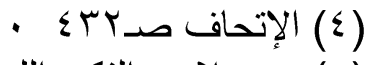

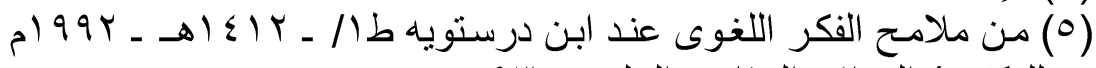

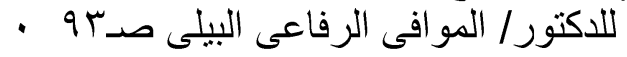


وقد بين سيبويه لنا أنه "قاث يجئ فعلت وأفعلت: المعنى فيهما واحـــ إلا أن اللغتين اختلفتا"(1)

فهاتان الصيغتان باتفاق المعنى قد نشأتا من اختلاف اللهجات، وهذاه

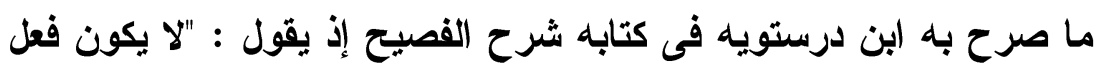

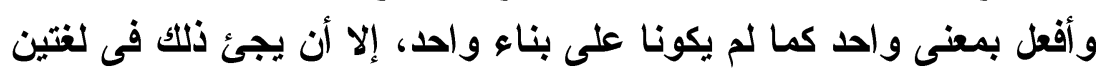

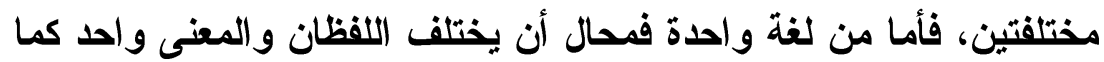
يظن كثير من اللغويين والنحويين"(r) .

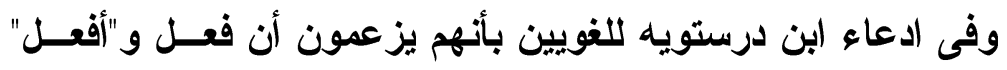

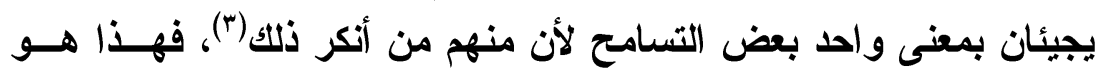

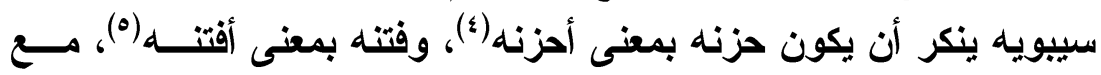

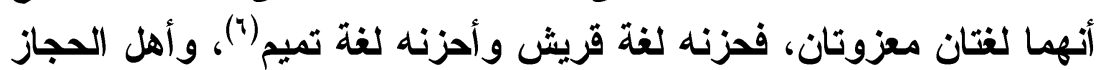

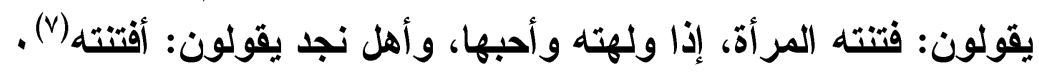

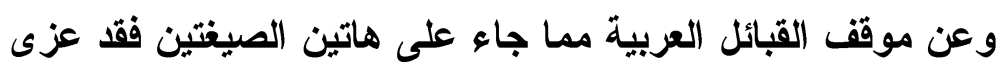

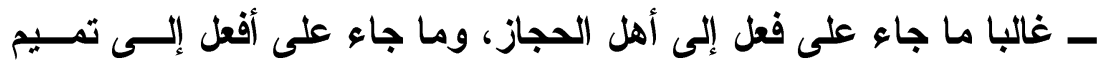

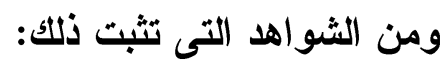

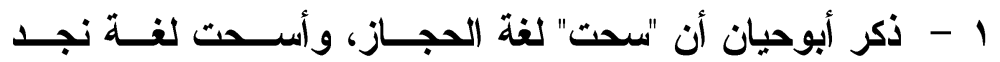
وتميم (^)

r - وذكر ابن منظور أن فتأه فتئا وفتو عا، ومـــا أفتـــأه الأخيــرة

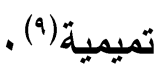

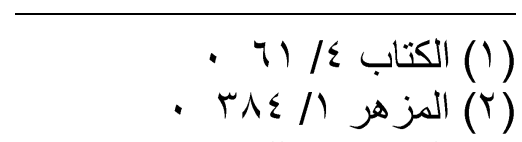

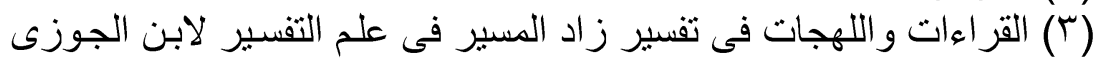

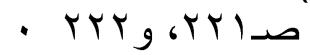

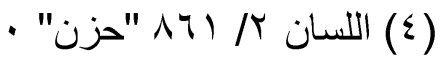

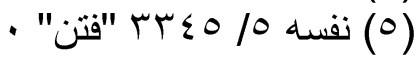

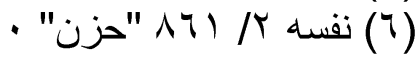

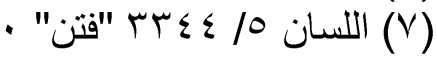
- البحر / البعان / (1)

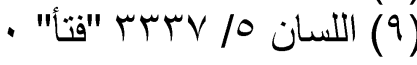


r - ـ وجاء فى المصباح أن جزى لغة الحجاز، و الرباعى المهـــوز

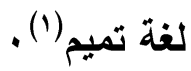

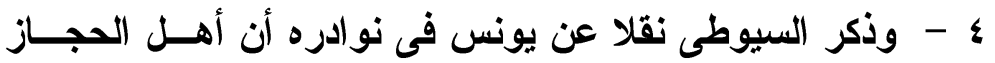
"لاته عن وجها يليته، وتميم ألاته يليته" (†) .

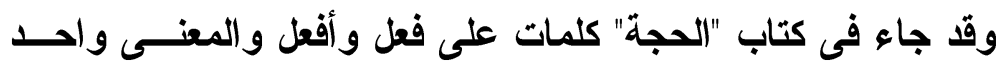

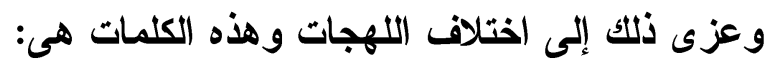

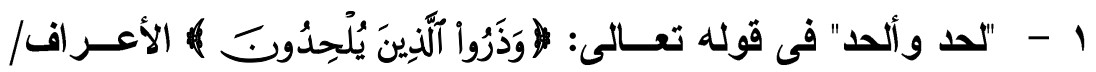
- 11.

يقول ابن خالويه: "يقرأ بضم الياء، وكسر الحاء، ويفتحهما هاهنــا

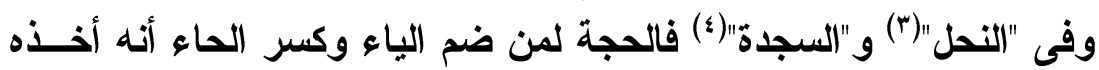

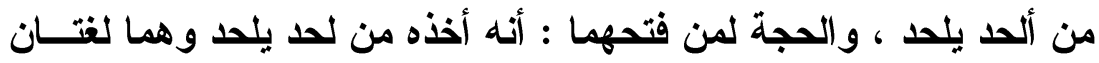

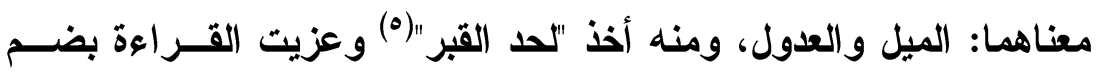

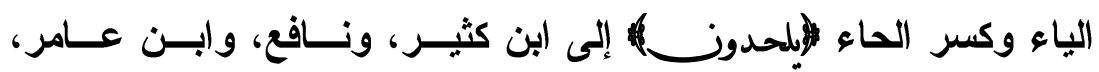

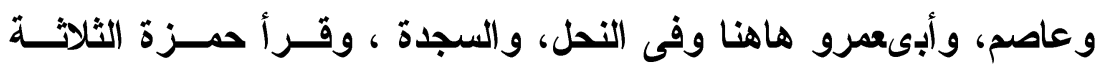

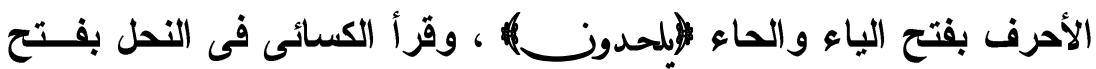

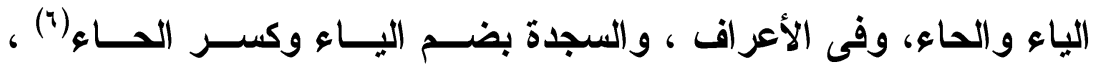

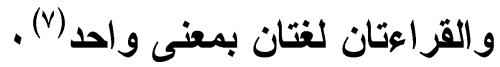

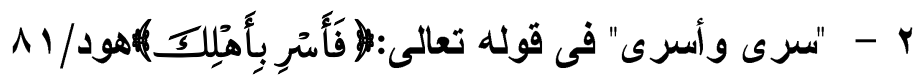

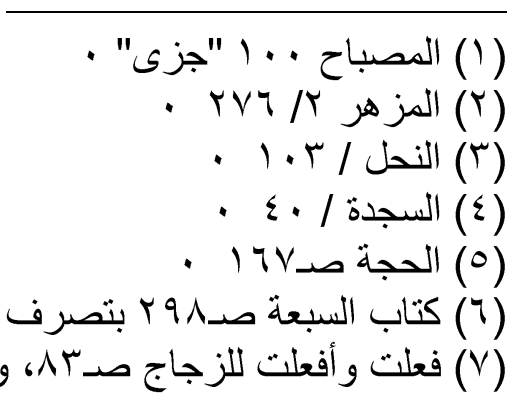


يقول ابن خالويه: "يقرأ بقطع الألف ووصلها، فالحجة لمن قطع: أنه

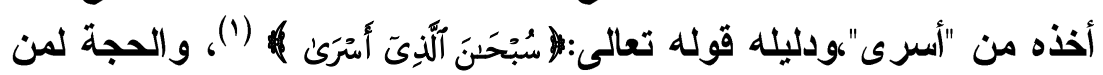

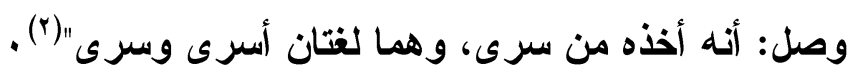

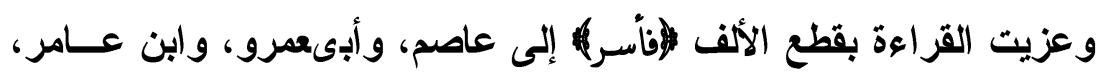

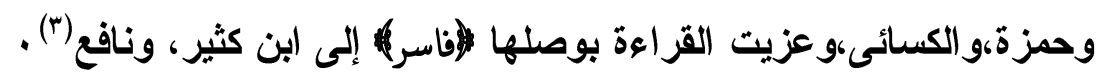

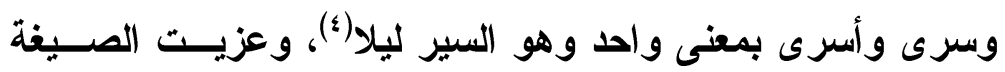
الرباعية "أسرى" إلى الحجاز (0) .

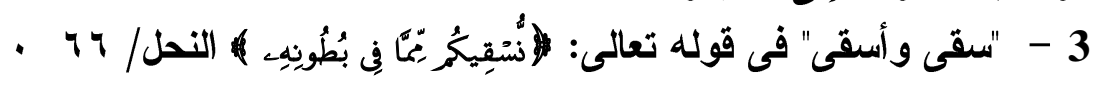

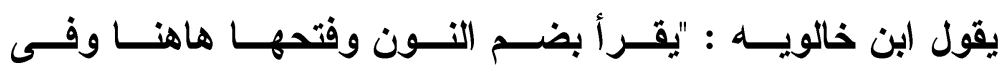

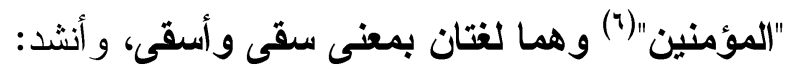

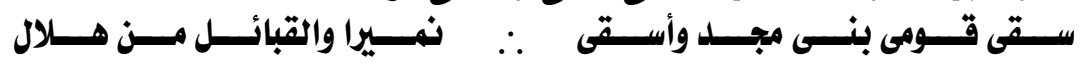

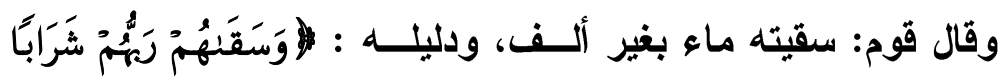

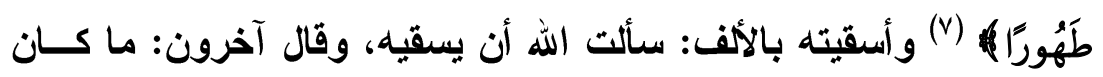
مرة واحدة فهو بغير ألف، وما كان دائما فهو بالألف"(1) .

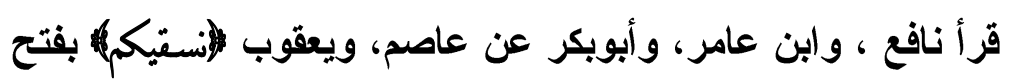

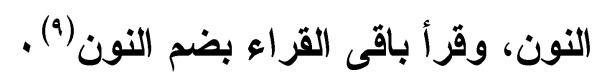

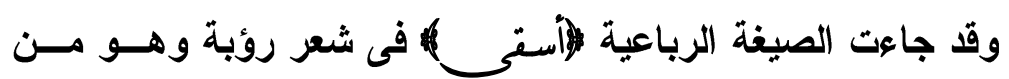
تميم وهذا يثبر إلى أنه تكلم بلغة قومه (1).

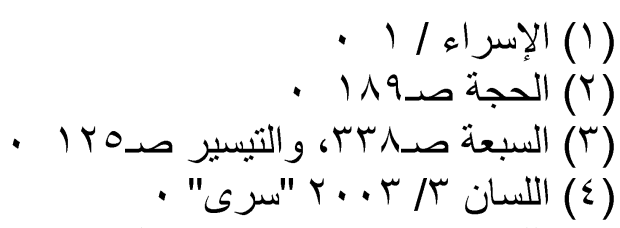

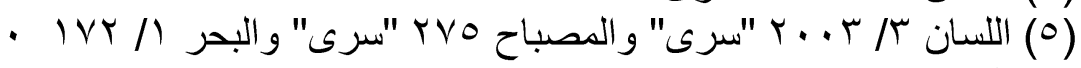

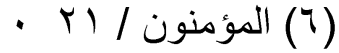

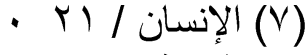

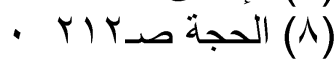

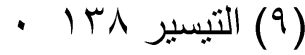




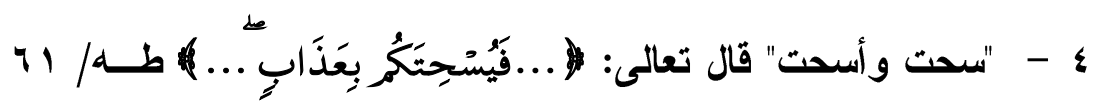

يقول ابن خالويه : "يقرأ بفتح الياء والحاء، وبضـــ اليـاء وكسـر

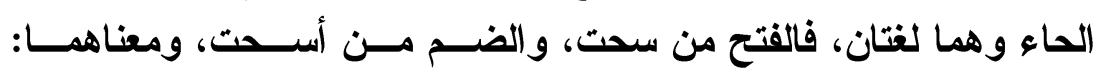

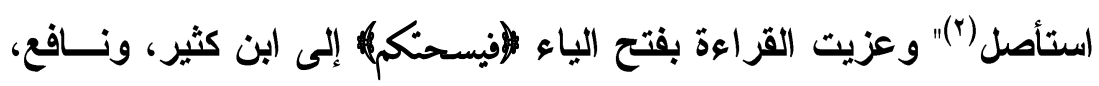

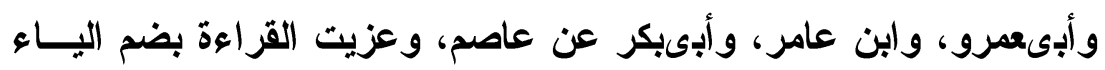

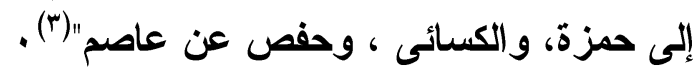

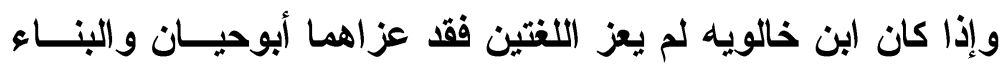
فالثلاثى للحجاز والرباعى لتميم (4) .

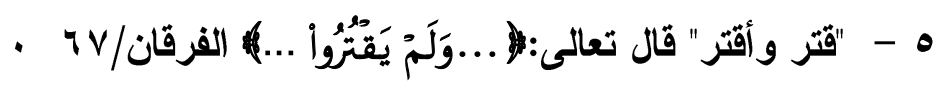

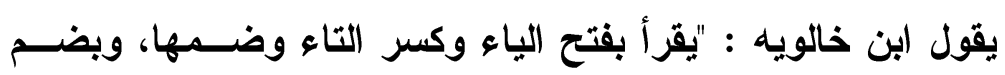

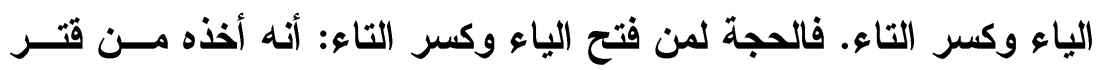

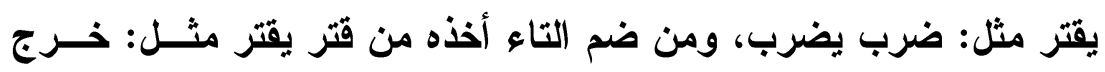

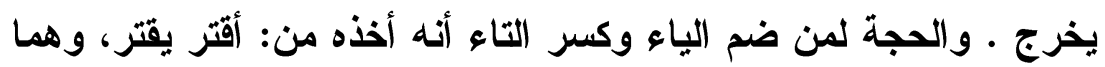

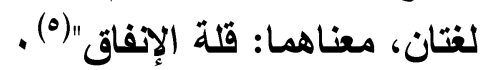

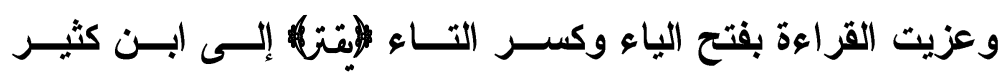

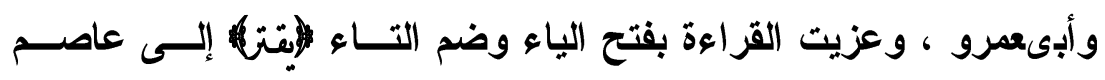

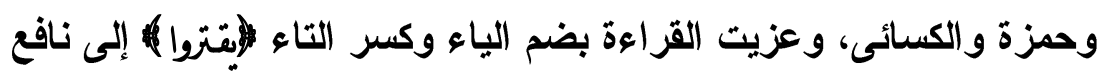

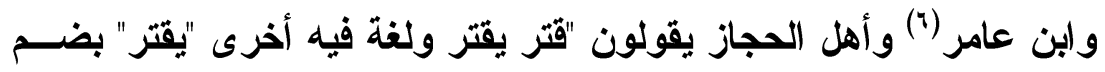

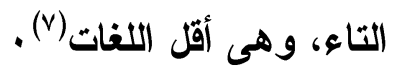

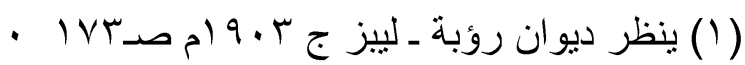

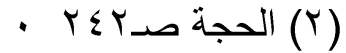

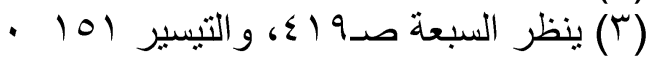

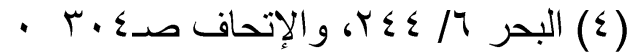

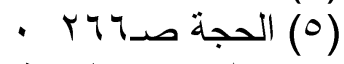

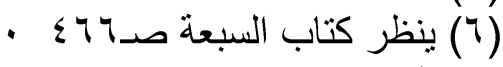

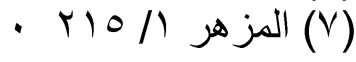




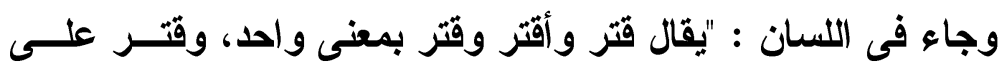

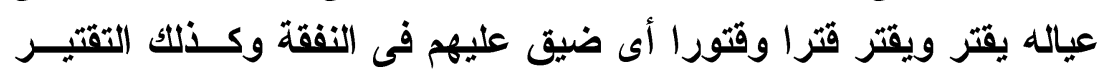

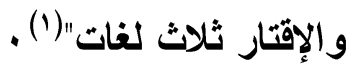

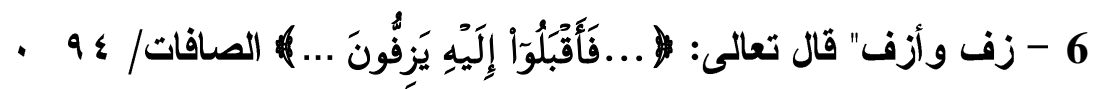

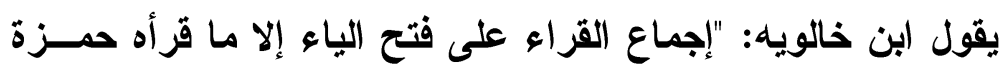

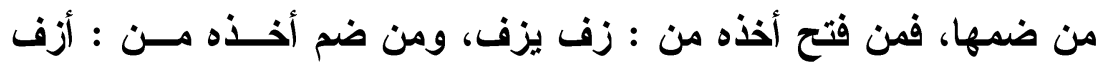

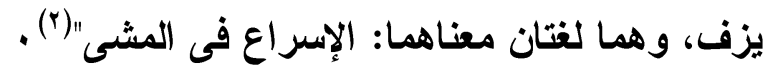

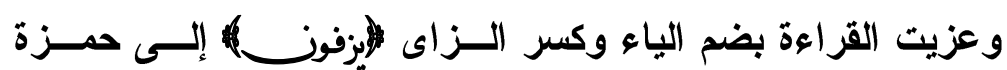

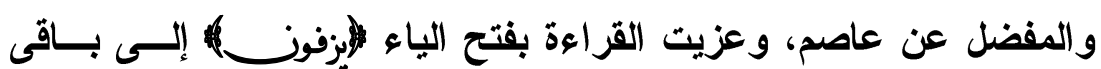

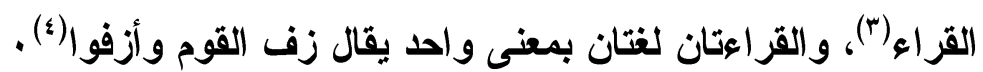

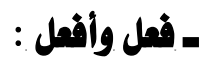

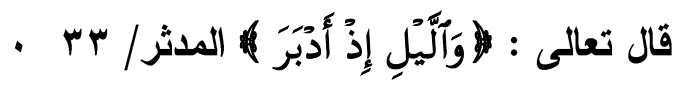

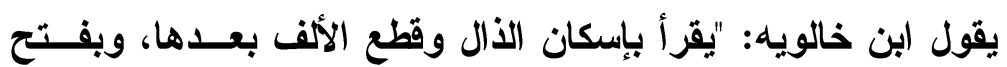

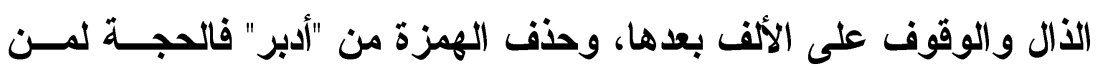

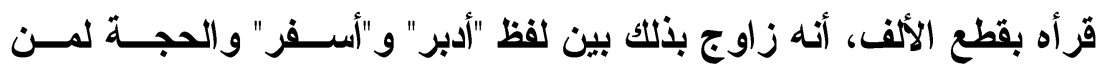

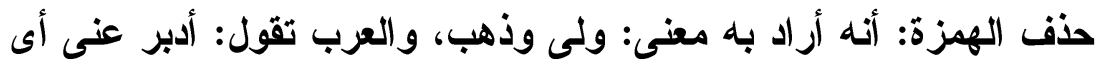

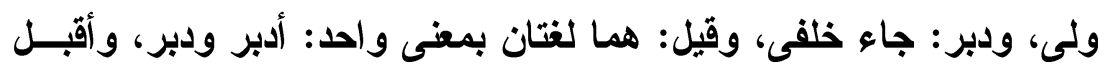

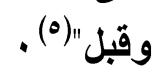

قرأ نافع، وحفص ، وحمزة، ويعقوب، وخلف بإسكان الذال ظرفا لما

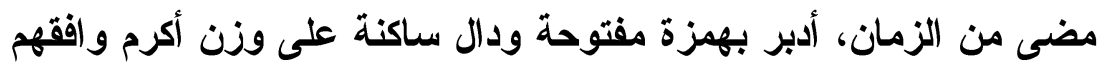

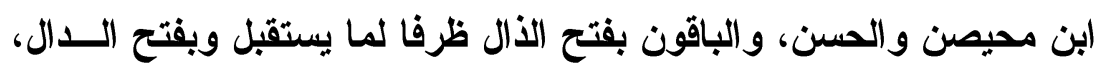

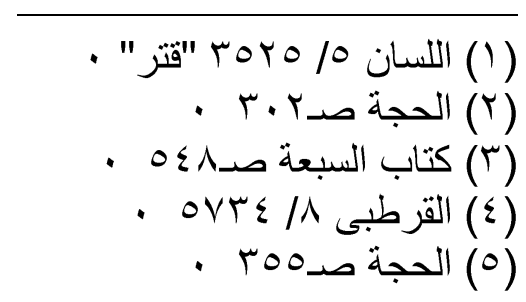


دبر على وزن ضرب لغتان بمعنى يقال دبر الليل وأدبر، وقيل أدبر تــولى إنى

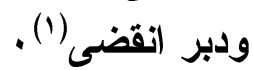

وقد عزيت الصيغة الثلاثية (بدرب) إلى قريش، والصـيغة الرباعيـة

$$
\text { "أدبر" إلى غيرهم (r) . }
$$

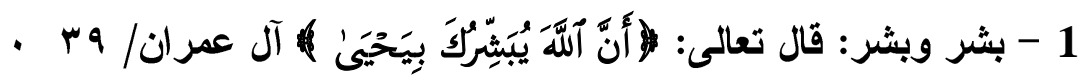

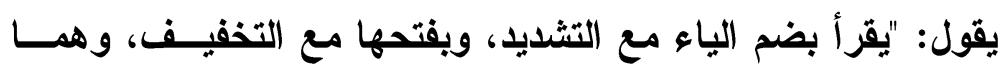

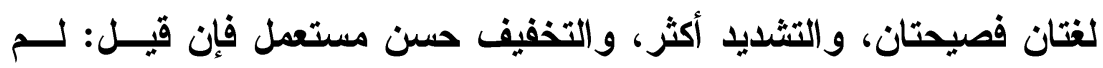

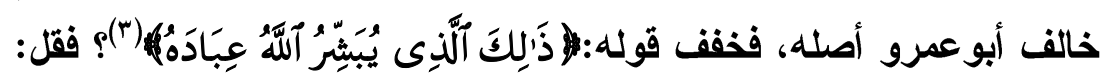
إن أباعمرو فرق بين البثارة والنضارة، فما صحبته الباء شدد فيه لأســه

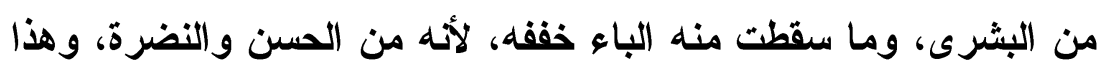

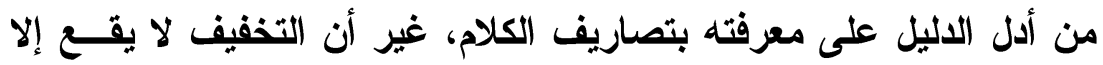

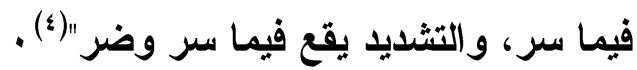

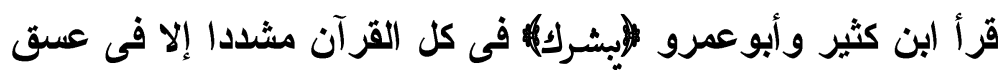

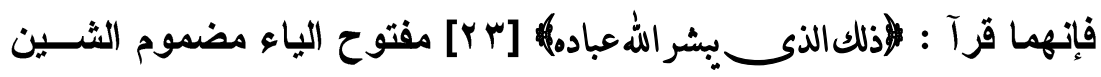

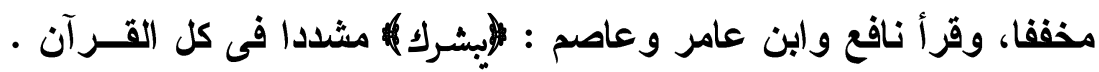

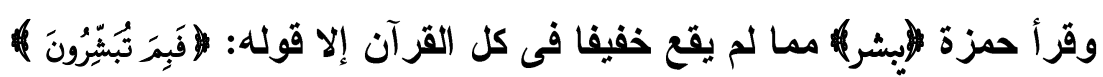

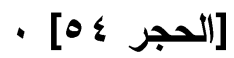
وقرأ الكسائى : يبشر مخففة فى خمسة مواضع: فى آل عمران فى في

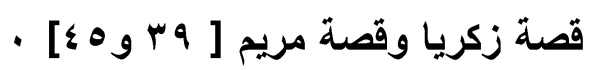

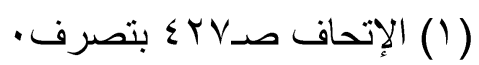

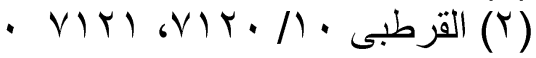
• (

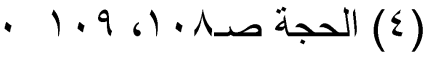




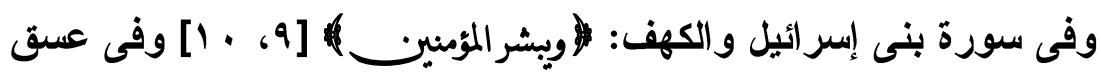

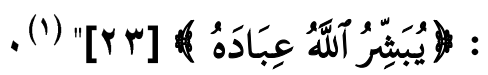

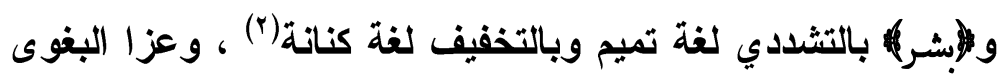

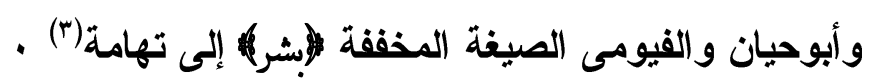

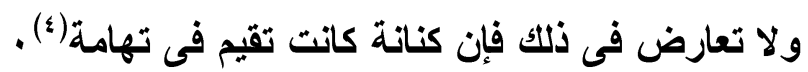

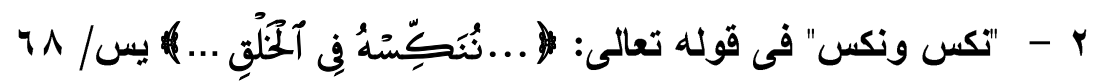

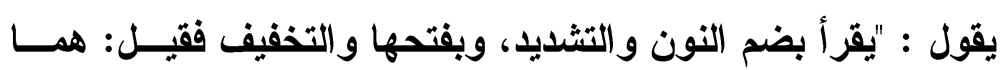

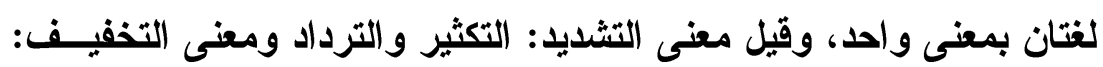

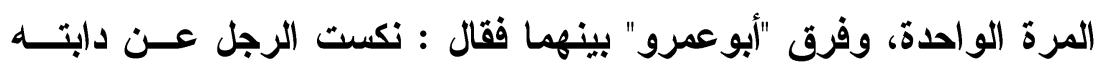

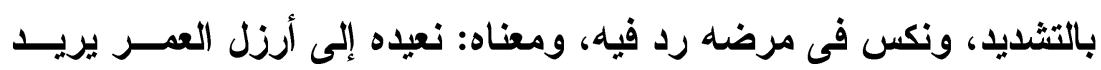

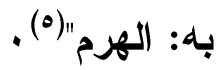

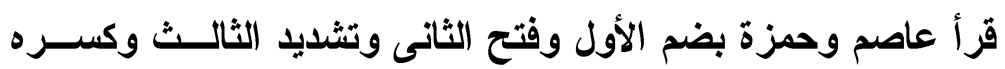

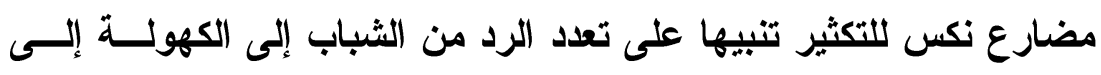

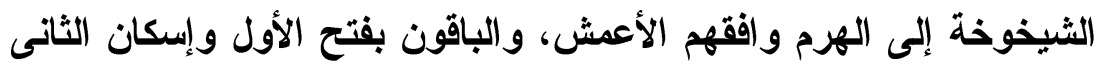

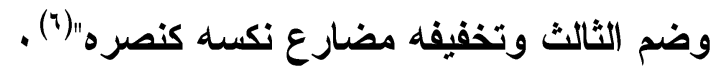

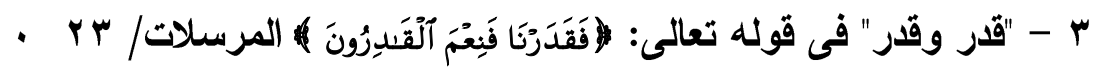

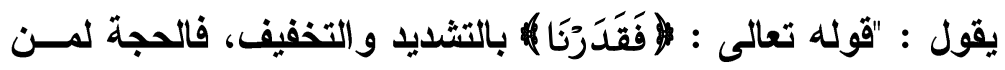

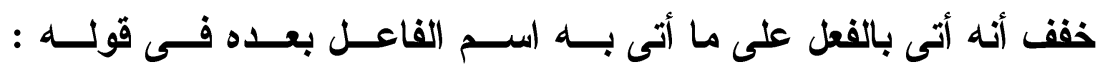

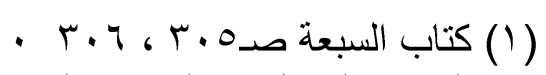

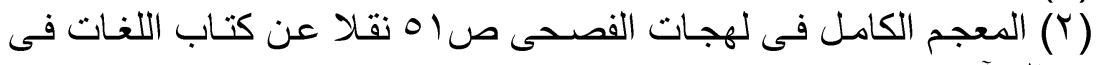

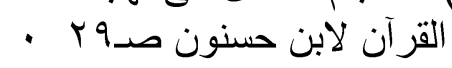

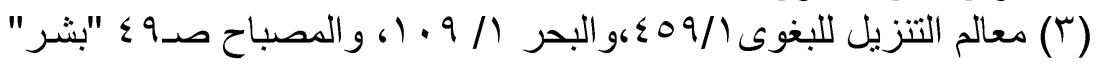




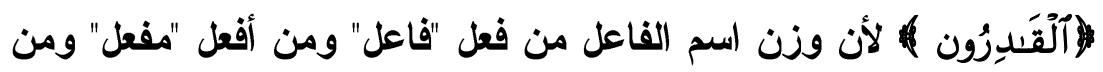

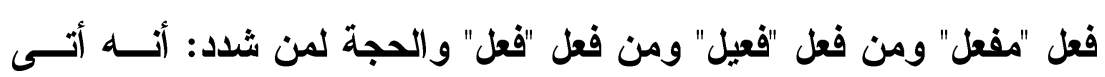

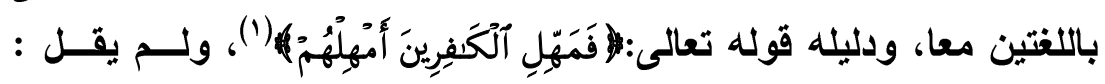

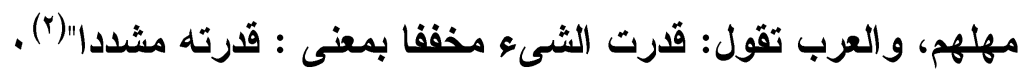

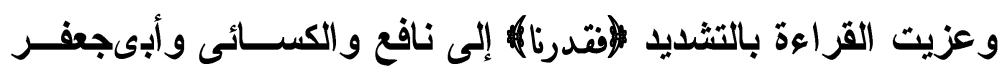

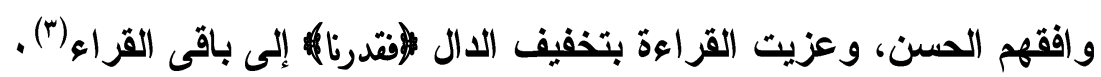

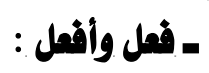

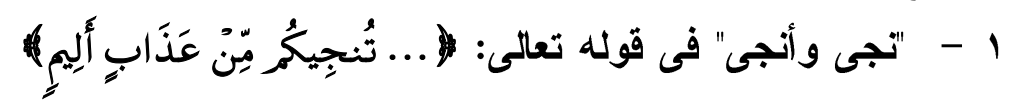

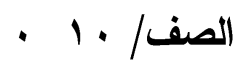
يقول : "إجماع القراء على التخفيف إلا "ابن اعــامر" فإنسـه شـــداد،

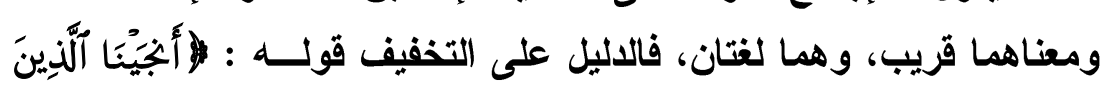

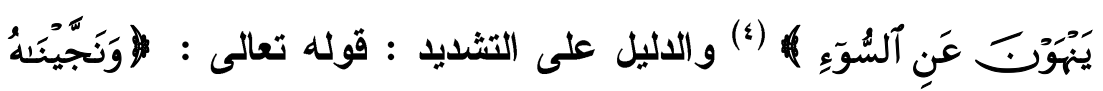

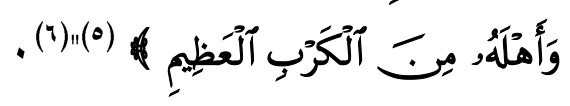

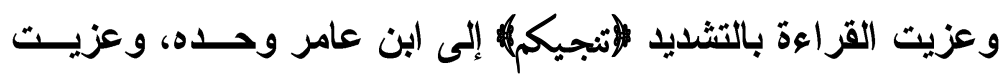

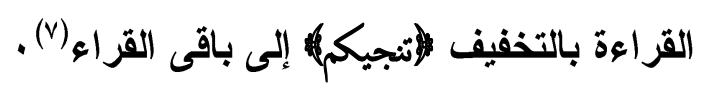

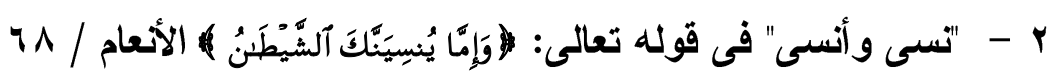

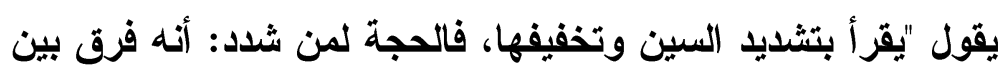

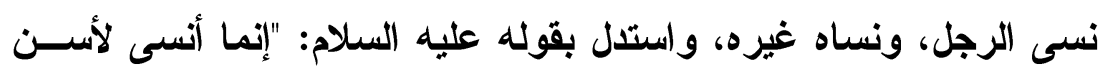

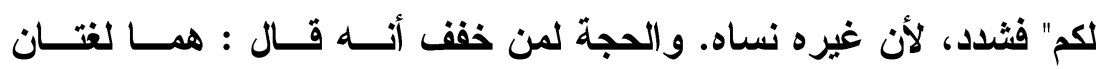

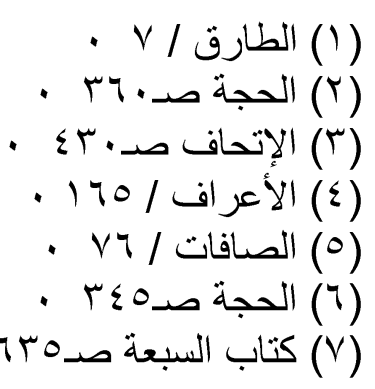




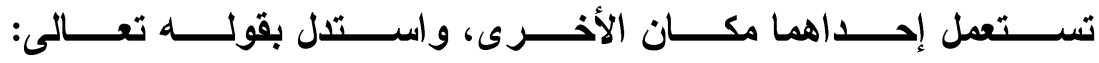

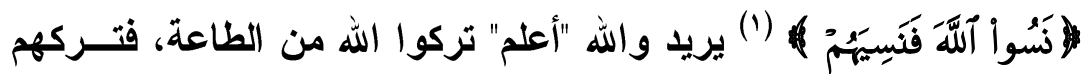

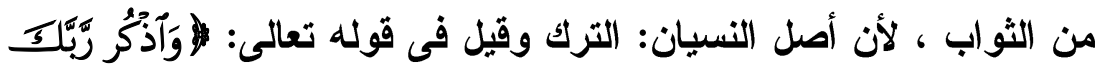

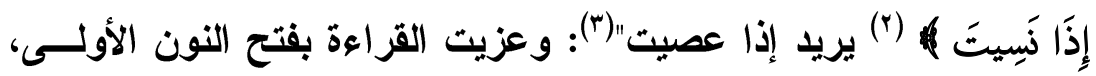
وبتثديد السين ميع النون الثانية (بنسينك) إلى (بن عامر، وعزيت القراعة بتسكين النون الأولى وبتشديد الثانية (بنسبيك) إلى باقى القراء(؛). ـ تمل واشتمل:

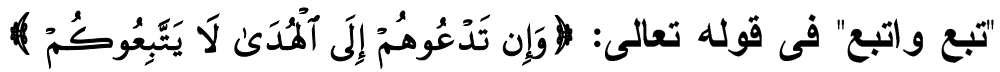

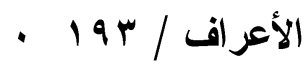

يقول : "يقرأ بالتشديد والتخفيف، فالحجة لمن شدد: أنه أراد به: لا يسيرون على أثركم، ولا يركبون طريقتكم فى دينكم، والحجة لمن خفــف:

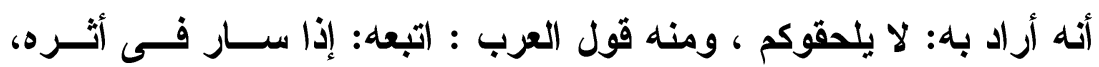

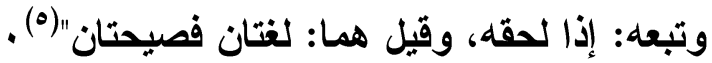
وعزيت القراعة بسكون التاء وفتح الباء (لايتبعوك) إلى نافع وحسده وعزيت القراعة بتثديد التاء (لإتبعوكم) إلى باقى القراع(ا) .

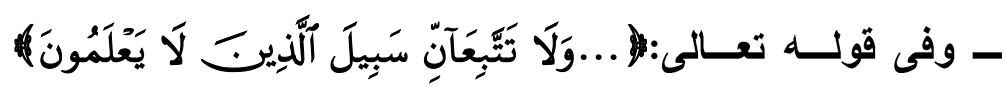
يقول : "يقرأ بإسكان التاء وتخفيفها، وبفتحها وتثـــيدها فالحجـــة

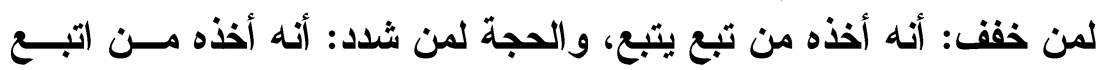

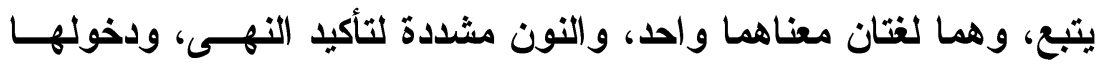

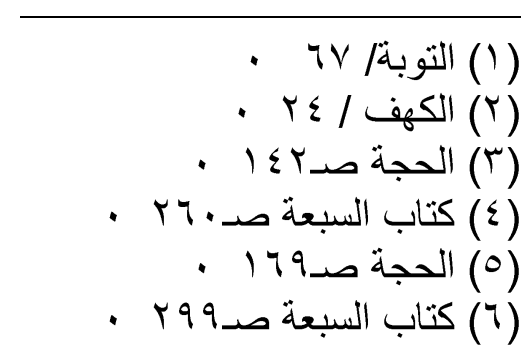


على الفعل مخففة ومشددة فى أربعة مواضع: للتأكيد فى الأمر، والنهـى،

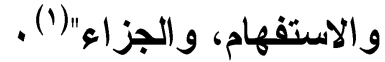

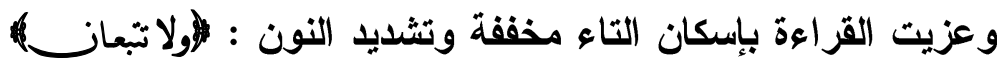

إلى ابن عامر وحده فى رواية ابن ذكوان، وفى رواية الحلو انى عن هثــام بـن

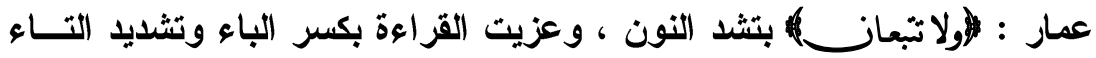

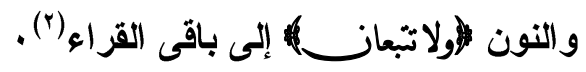

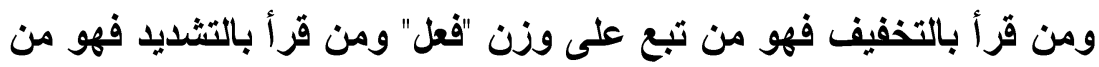

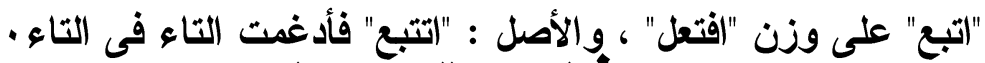

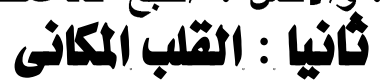

تعريفه : هو تصبير حرف مكان حرف بالتقديم والتـــأخير (ॅ) وقيــل

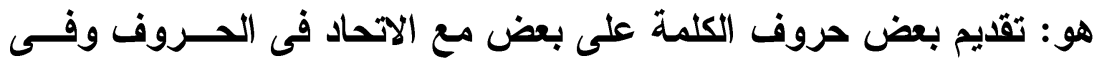

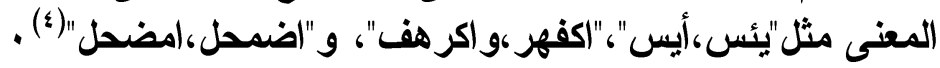

سبب وجوده:

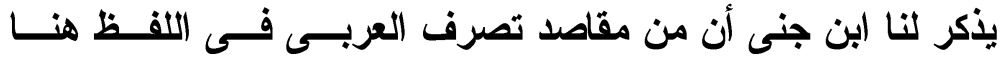

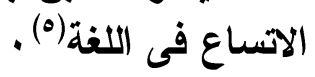

وينقل السيوطى أن الاضطرار من أسباب القلب المكانى(") وقد أرجع

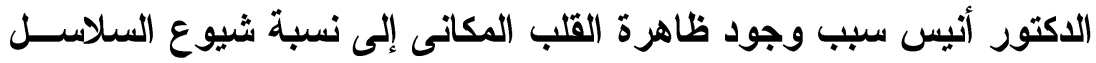

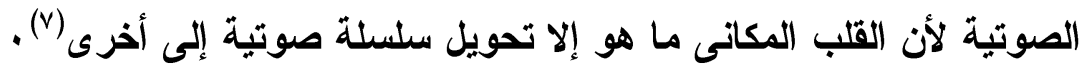

\section{آراء العلماs فى القالب المكانى :}

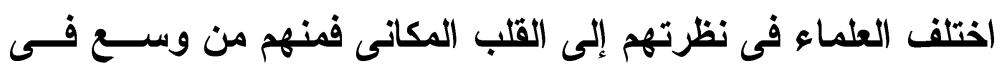

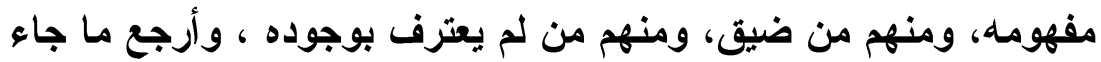

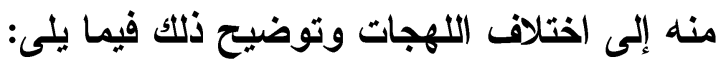

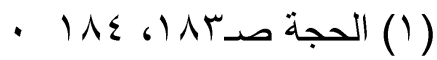

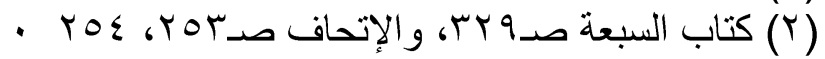

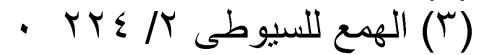

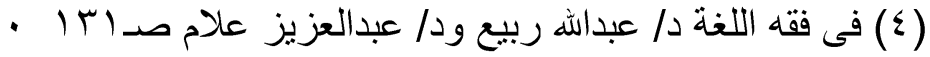

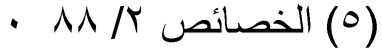

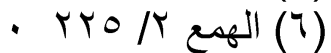

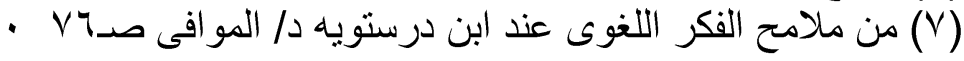


1 - يذهب جمهور اللغويين إلى أن الكلمات التى اتعدت معانيهــا

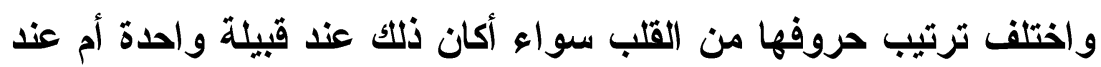

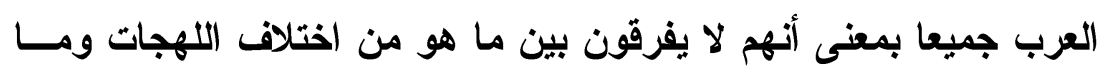
هو موجود فى الاستعمال اللغوى العام (1).

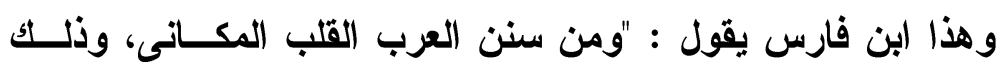

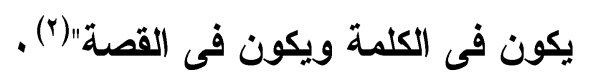

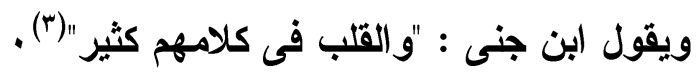

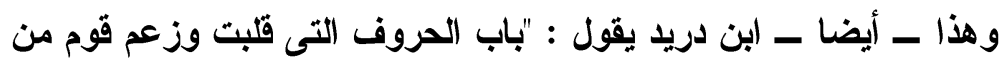

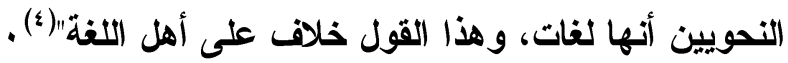

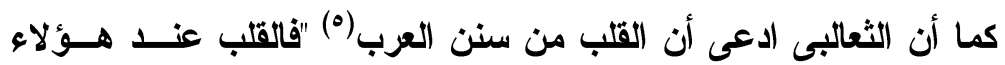

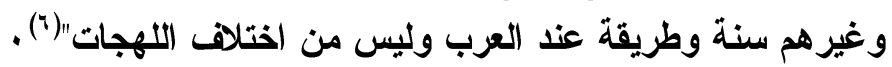

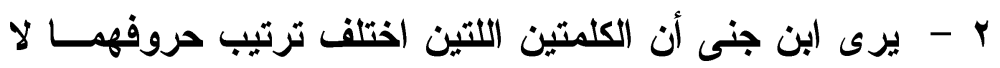

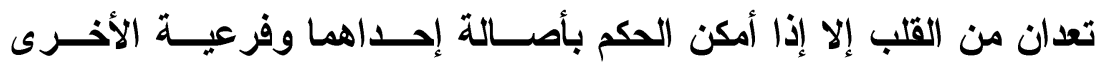
ومقياس الأصالة أن تكون إحدى الكلمتين أوسع تصرفا من الأخرى أما إذا إلا

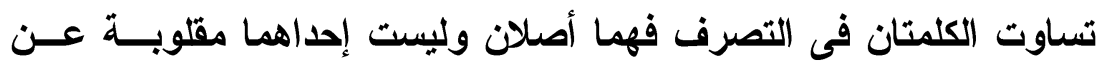
الأخرى (v) (الماوت

وخرجت ألفاظ كثيرة من القلب المكانى عند ابن جنى بسـبب هــــا

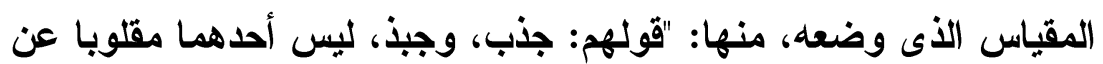

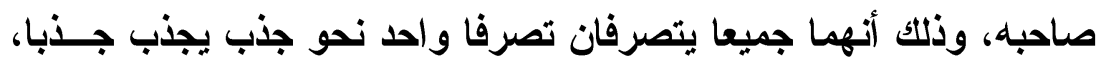

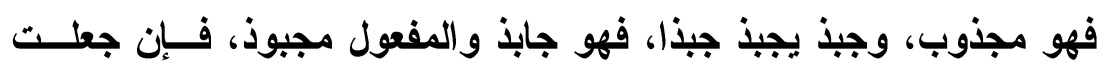


أحدهما أصلا لصاحبه فسد ذلك لأنك لو فعلته لم يكن أحدهما أســد بهـــه

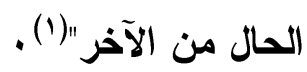

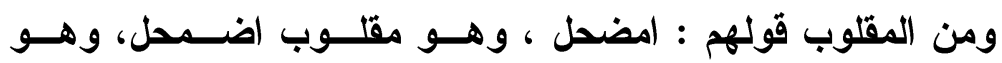
الاضمحلال ولا يقولون امضحلال (r) . فابن جنى حكم على قلب أحد اللفظين عن الآخر بكثرة تصرفه وقلة الآلة

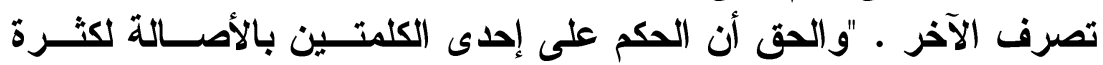

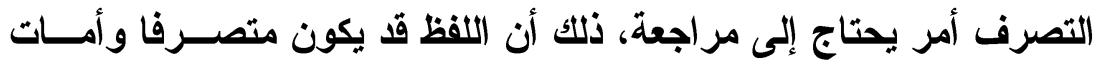

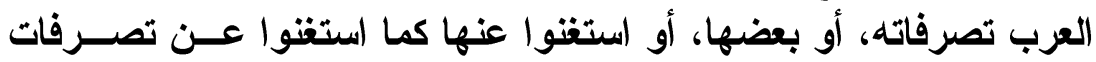

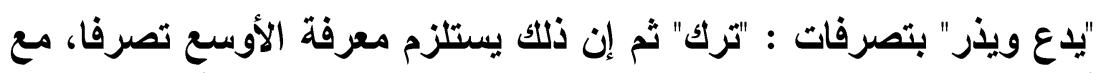

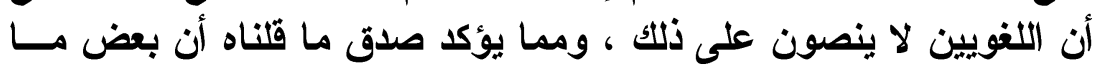

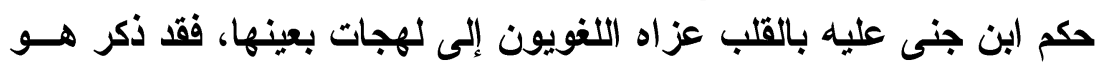

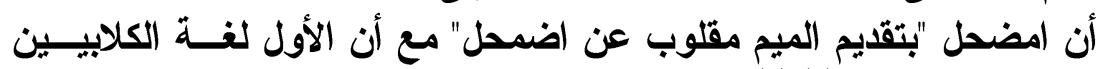
كما ذكر اللغويون" (r)(")(

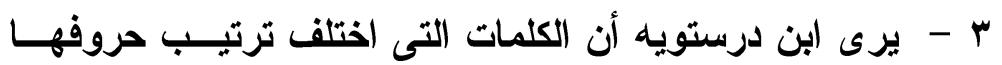

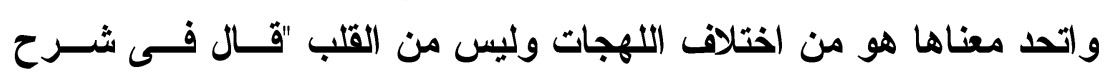

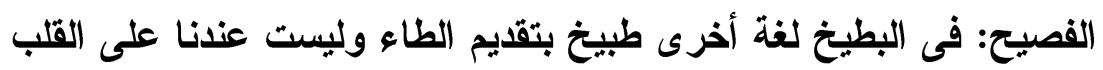

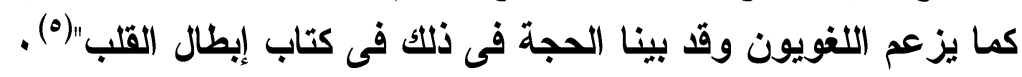

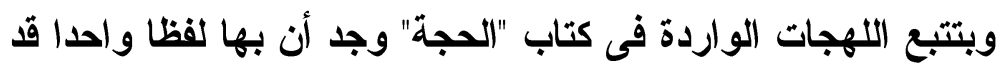
وقع القلب فيه هو لفظ "رأى" وجاء ذلك فى الموضع الآتى :

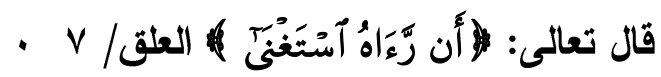

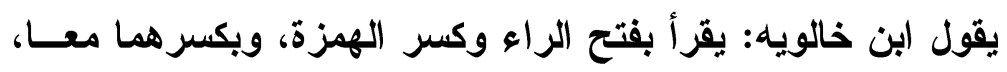

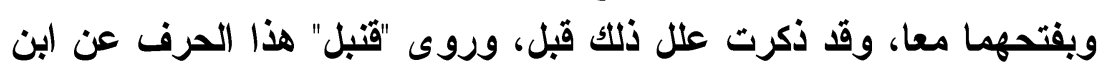

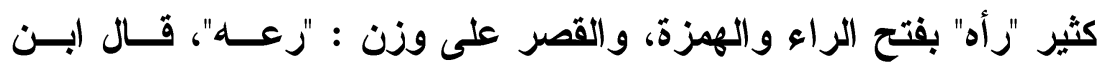

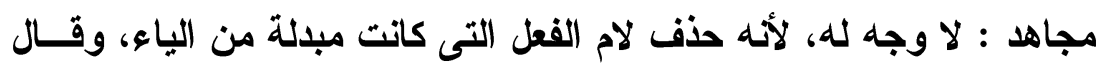

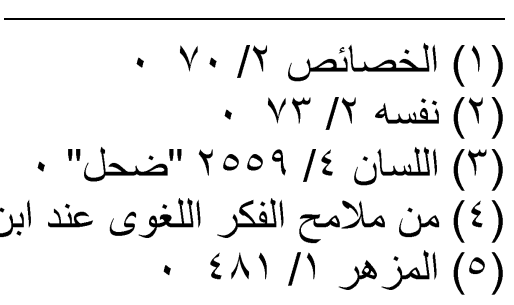


بعض أهل النظر: أحسن أحوال ابن كثير : أن يكون قرأ هذا الحرف بتقــديم

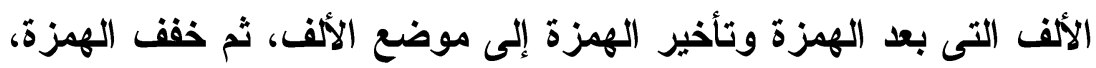

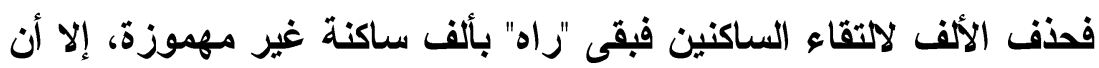

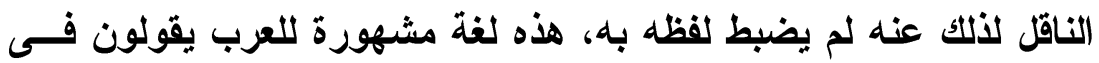

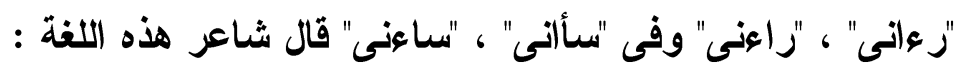

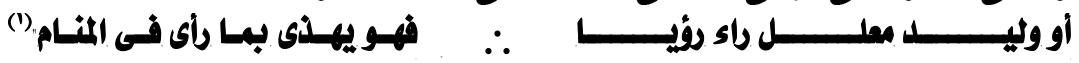
وعزيت القراعة بغير ألف بعد الهمزة "أن رأه" بوزن رعهد إلى ألى أبـن

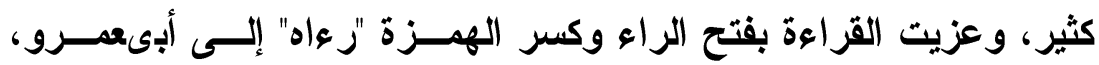

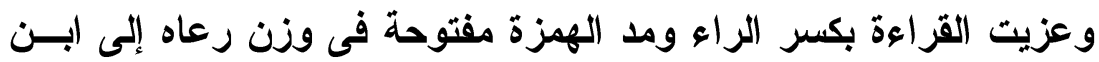

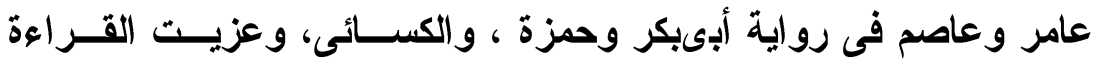

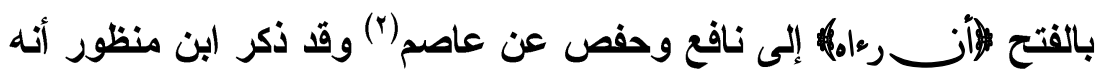

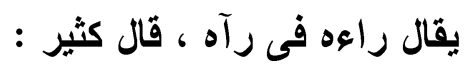

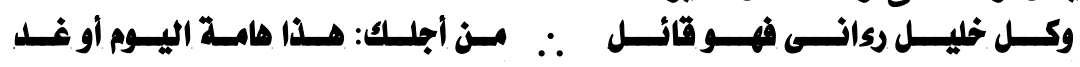

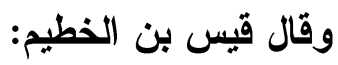

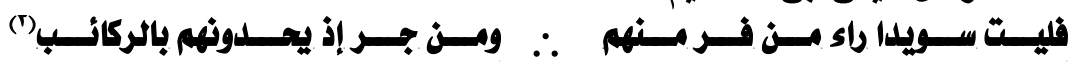

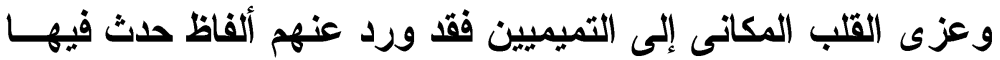

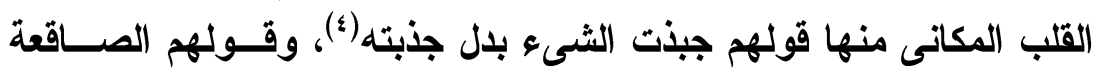

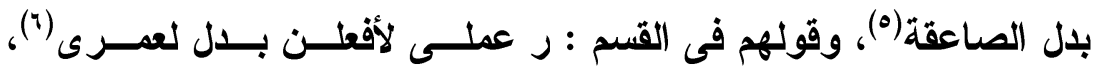

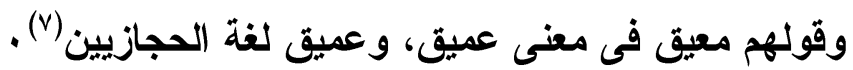

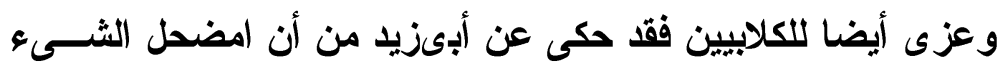
بمعنى ذهب لغة الكلابيين فى اضمحل(^) .

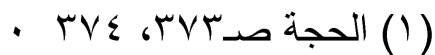

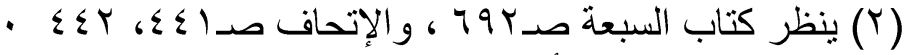

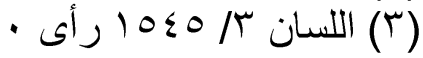

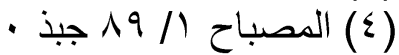

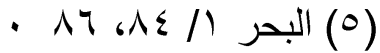

$$
\begin{aligned}
& \text { - rVV/ } \\
& \text { - البحر }
\end{aligned}
$$

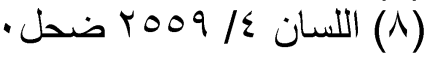




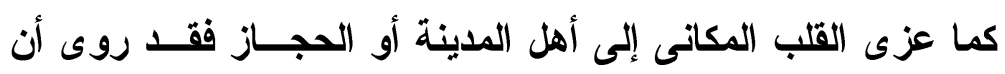

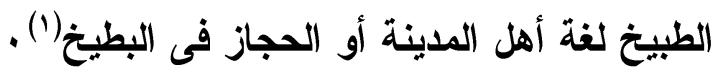




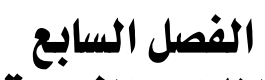 \\ الثطواهر النحوية النمية

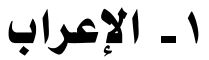

الإعراب فى الافة: البيان ، يقال أعرب عن حاجته إذا أبان عنها(1).

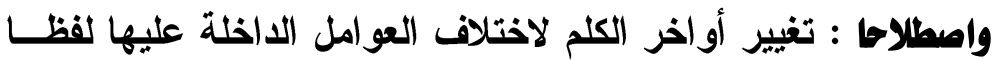

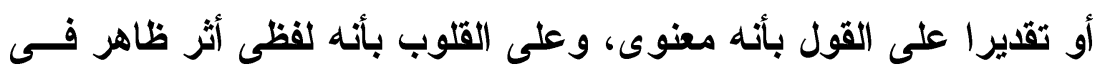

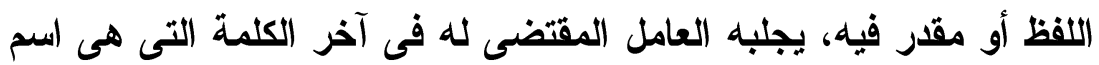

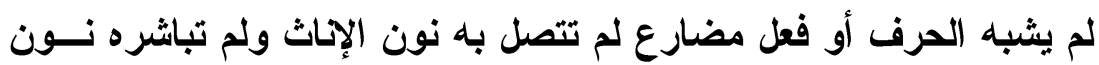

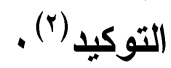
والإعراب من أساليب الأداء وصور التعبير التى لا تقبل عند العرب

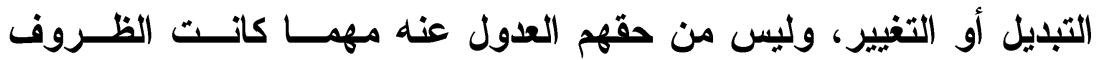

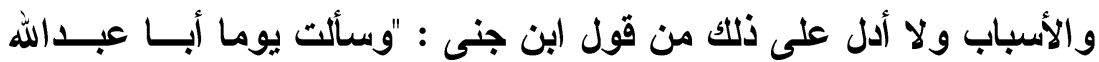

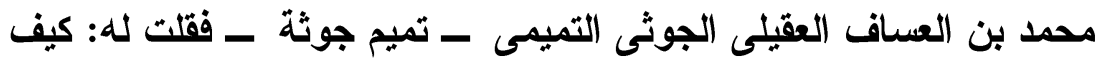

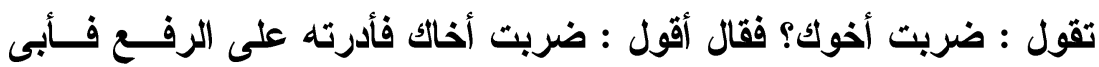

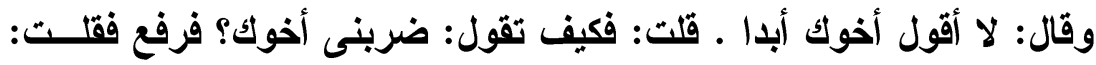

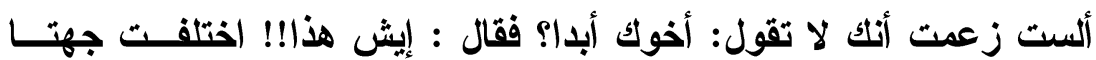

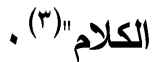

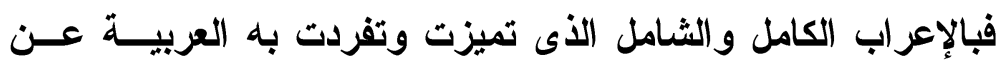

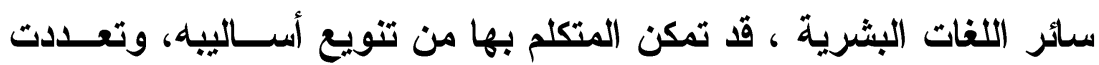

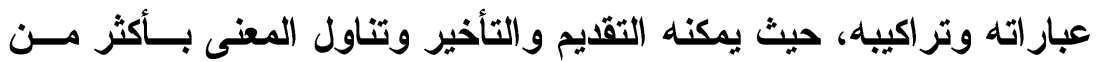

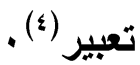

وبالإعراب يعرف الفاعل من المفعول إذ يقول ابن جنى: "هو الإبانة

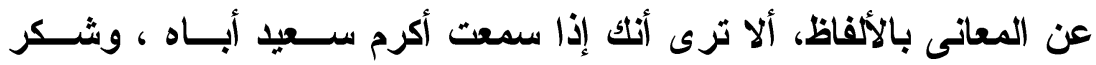

$$
\begin{aligned}
& \text { - VY/ (1) شرح المفصل }
\end{aligned}
$$

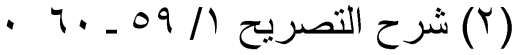

$$
\begin{aligned}
& \text { - VT/ / (Y) الخصائص (Y) }
\end{aligned}
$$

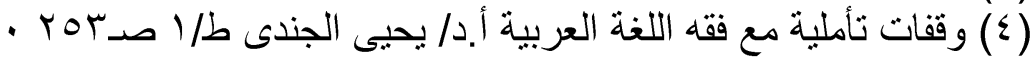




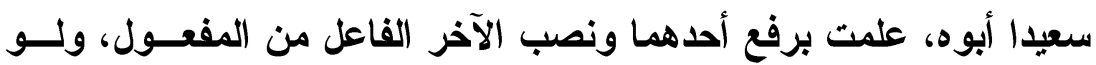
كان الكلام شرحا واحد لاستبهم أحدهما من صاحبه" (1) .

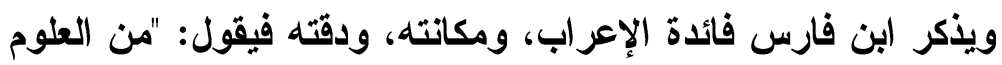

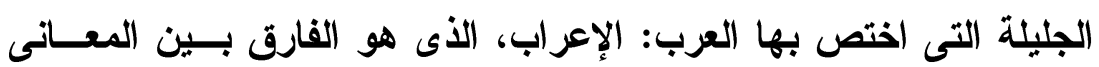

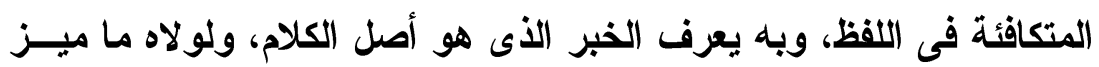

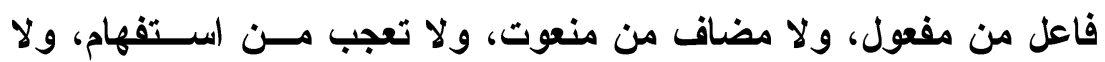

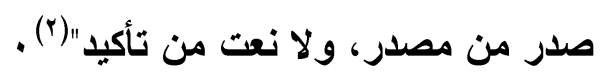

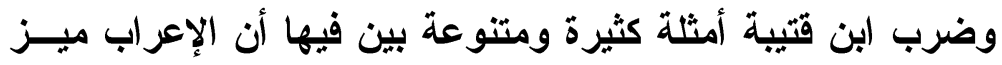

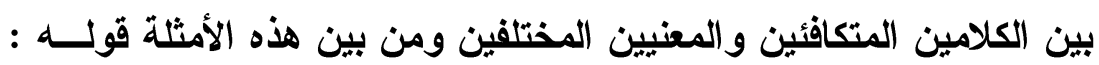

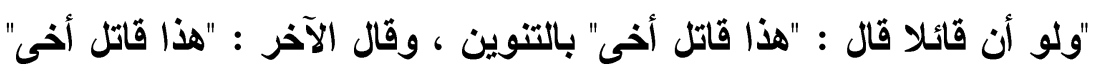

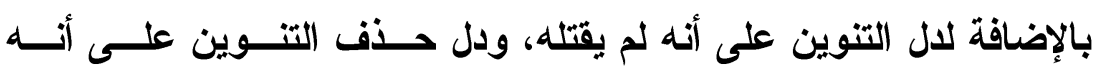

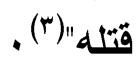

ولهذا فإنتا لو ألزمنا آخر الكلم السكون لخفيت علينا المعسانى "فأــم يعلم الفاعل من المفعول · ولو اقتصر فى البيان على حفظ المرتبة فـيعلم

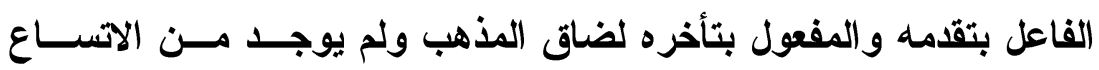

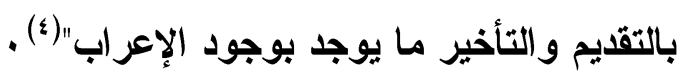

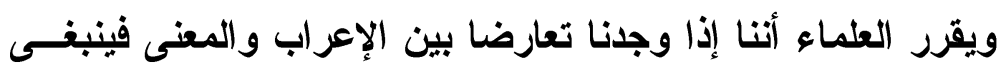

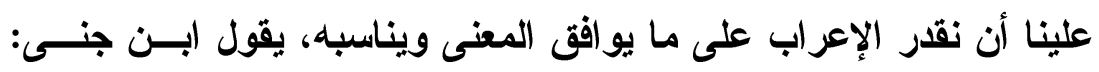

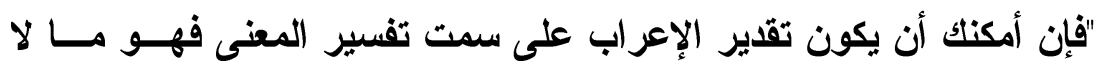

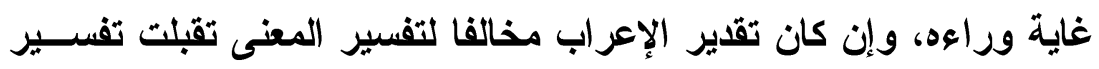

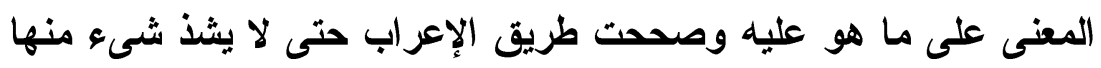

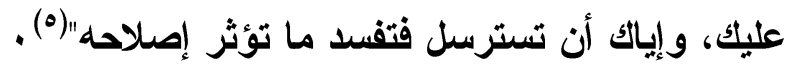

$$
\begin{aligned}
& \text { (1) (1) الخصائص / (1) }
\end{aligned}
$$

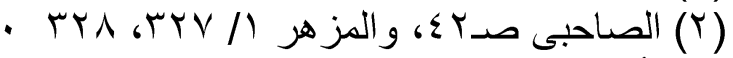

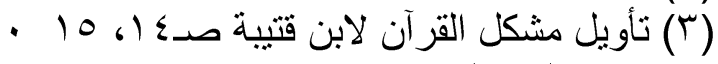

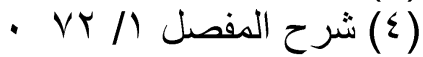

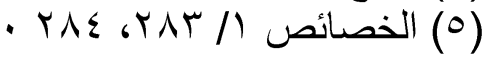


ويجب على من يتناول لفظا من ألفاظ كتاب الله بالإعراب - أن يفهم

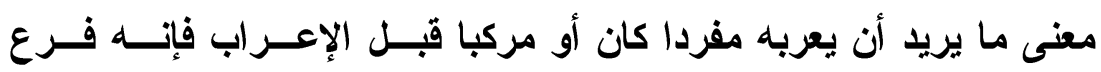

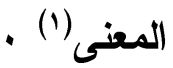

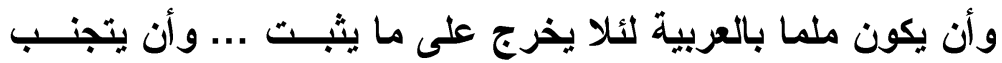

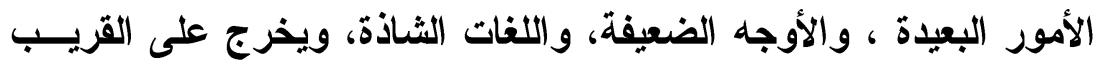

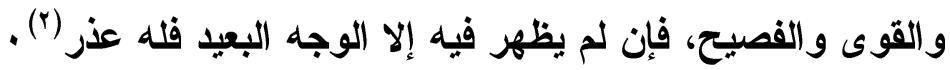

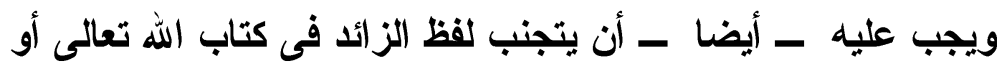
التكرار ولا يجوز إطلاقه إلا بتأويل (ז) .

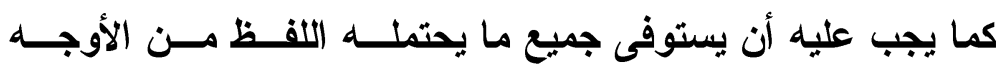

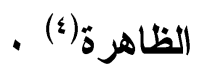

وأنواع الإعراب أربعة هى : "الرفع والنصب والجر والجزم .. فأمسـا

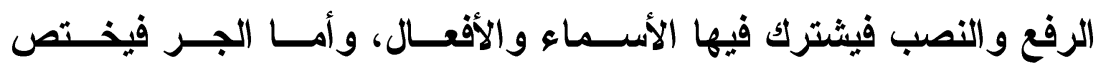

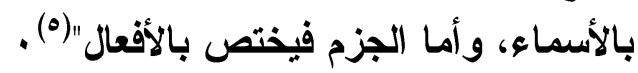

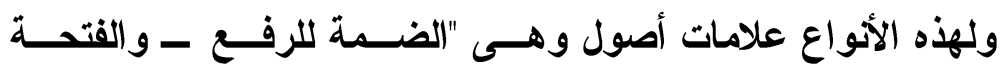

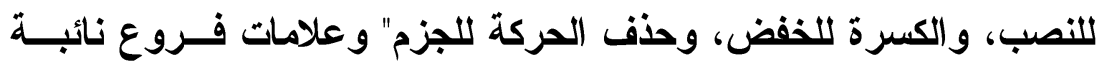

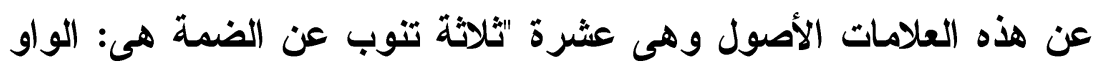

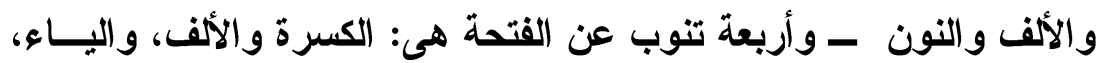

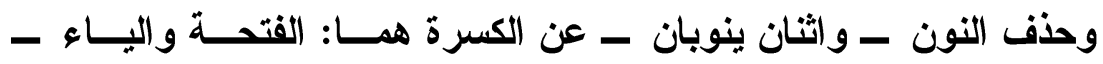

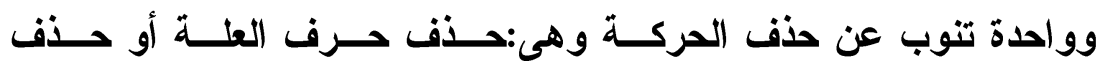

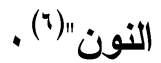

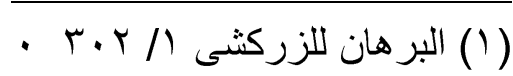

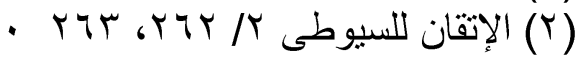

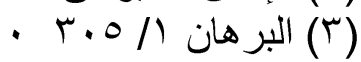

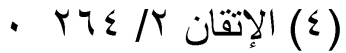

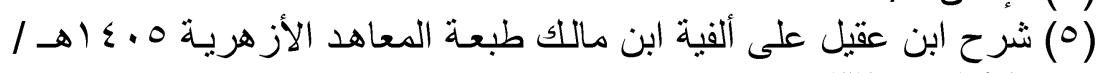

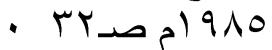

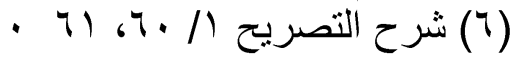


وقد جاء فى كتاب الحجة أسماء وأفعال تعـددت فيهــا اللهجــات،

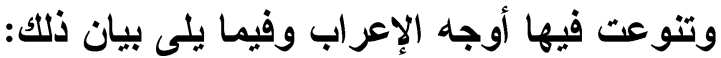

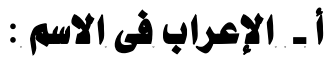

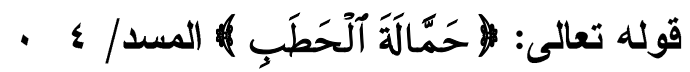

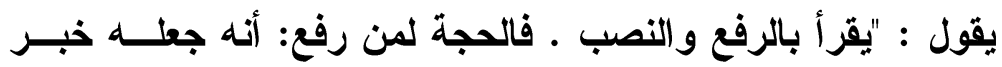

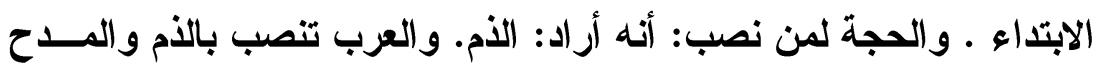

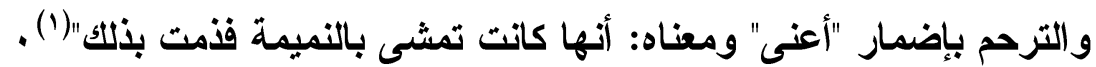

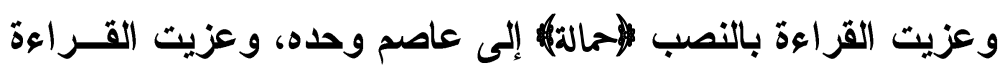

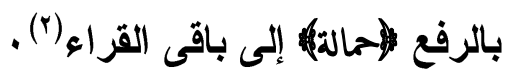

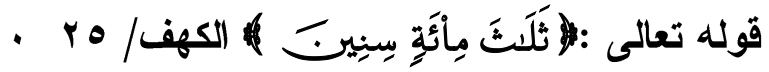
يقول: "يقرأ بإثبات التنوين، وبطرحه والإضافة. فالحجة لمن أثبـــ

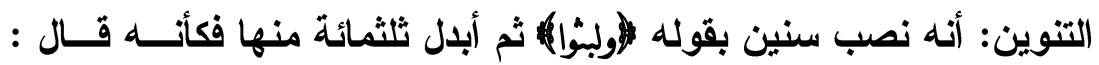

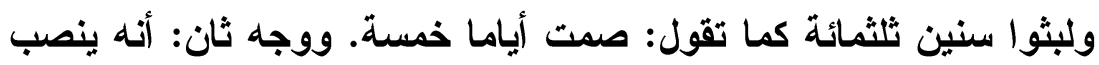

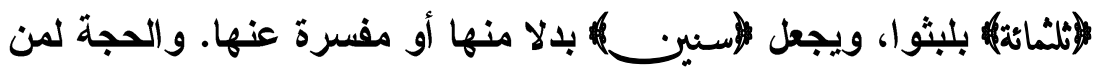
أضاف : أنه أتى بالعدد على وجهه، وأضافه على خفة بالمفسر مجموعـا

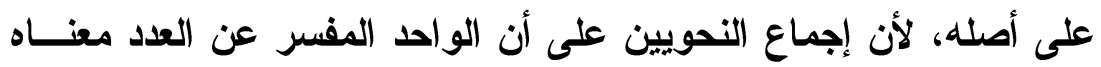

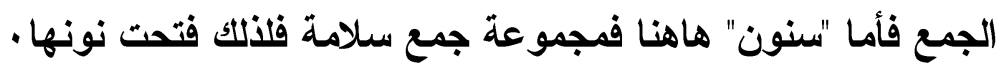

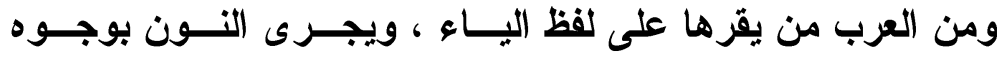

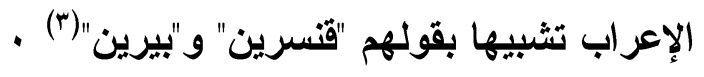

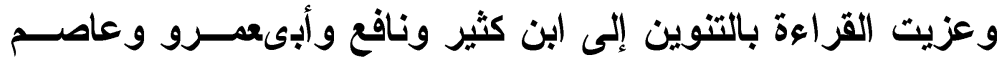
وابن عامر، وعزيت القراعة بدون التنوين إلى حمزة و الكسائى(؛) . 


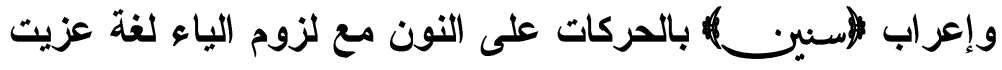

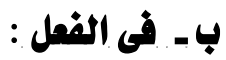

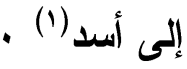

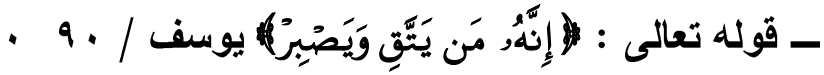

يقول: "القراءة بكسر القاف وحذف الياء علامة للجزم بالثرط إلا ما

$$
\text { رواه قنبل عن ابن كثير بإثبات الياء. }
$$

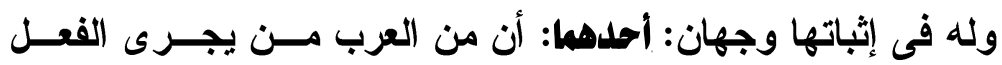

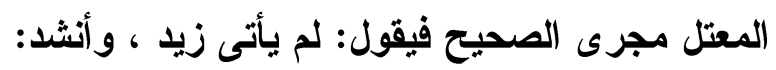

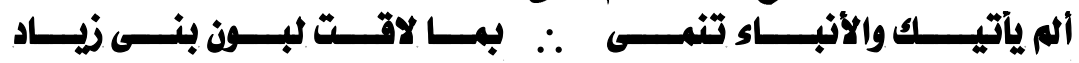

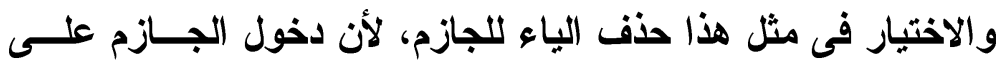

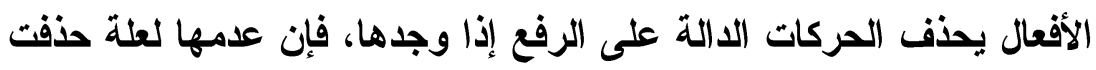
الحروف التى تولات منها الحركات لأنها قامت مقامها ودلت على الدات ما كانت

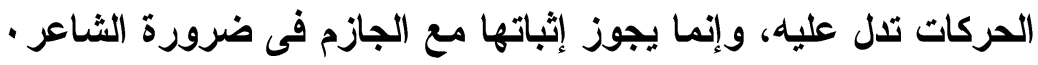

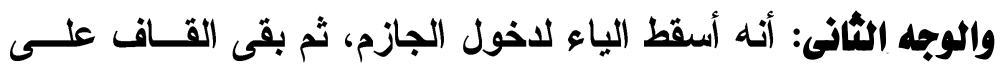

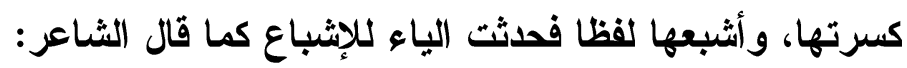

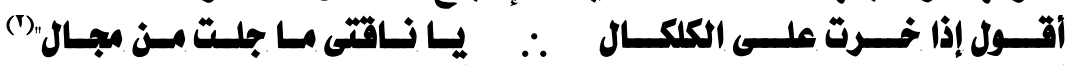

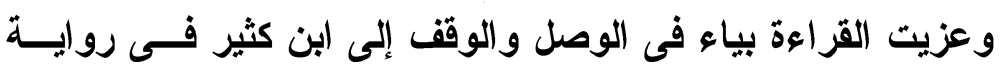

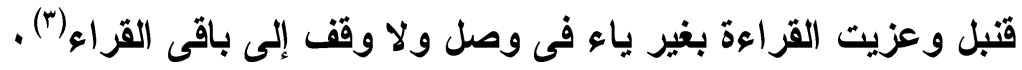

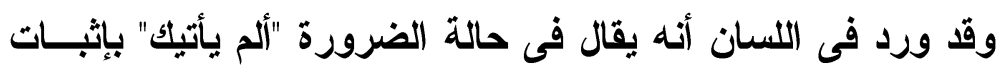

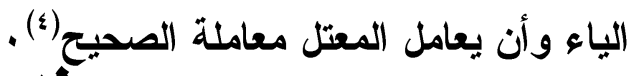

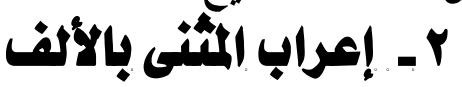

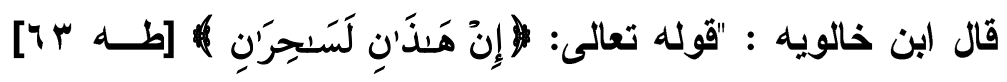

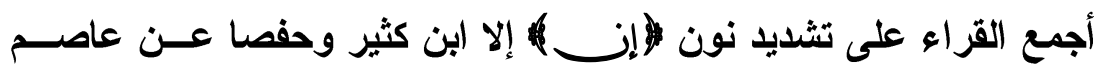

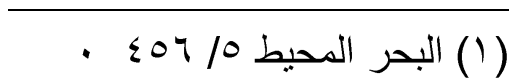

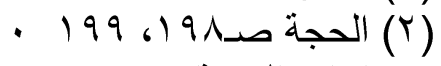

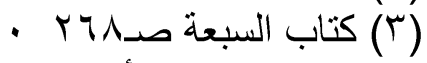

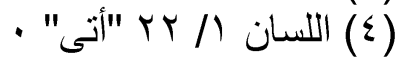




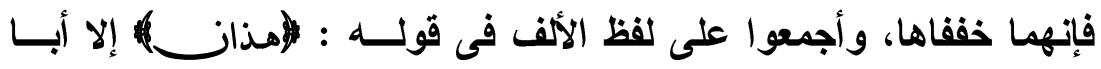

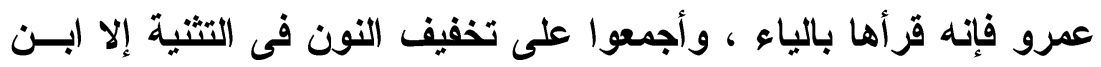

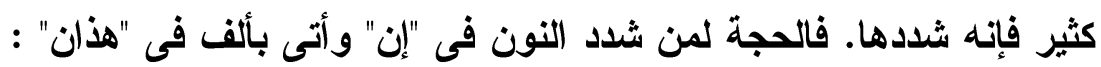

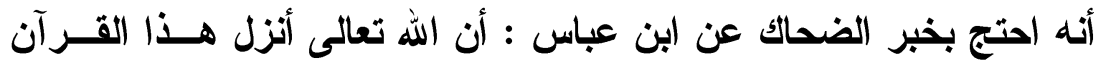

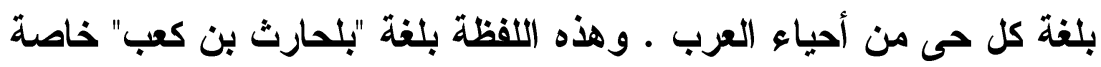

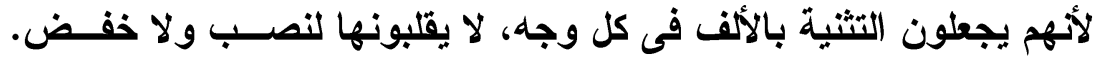

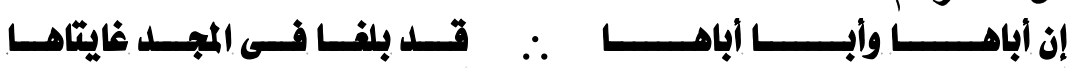

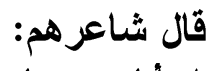

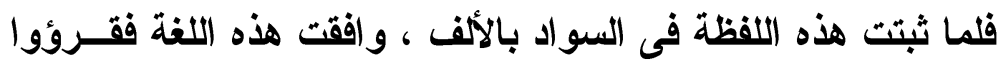

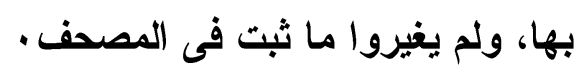

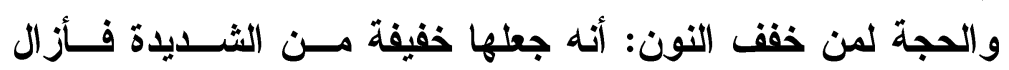

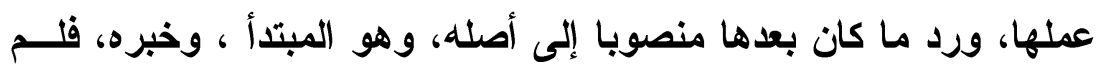

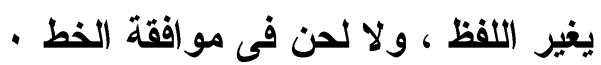

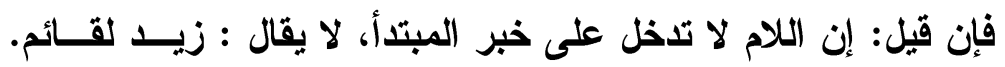

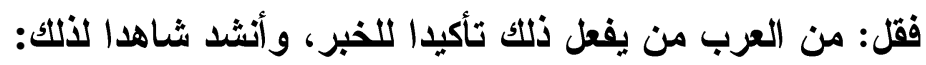

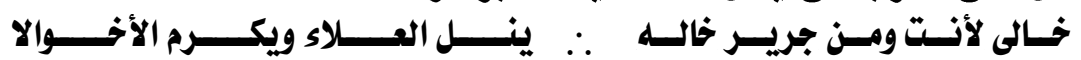

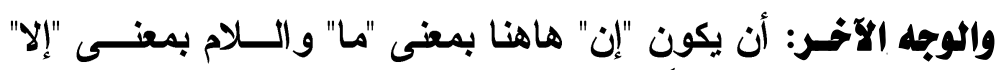

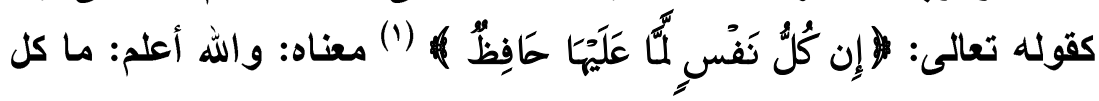
نفس إلا عليها حافظ.

وقال أبو العباس المبرد: أولى الأمور بإن المشددة أن تكون هاهنــا

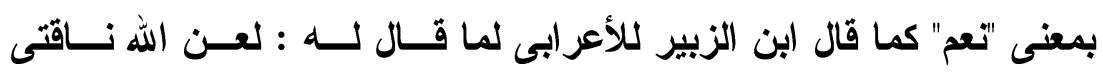

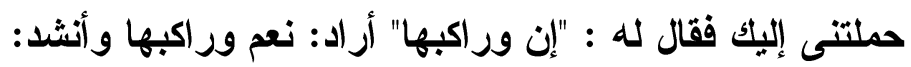

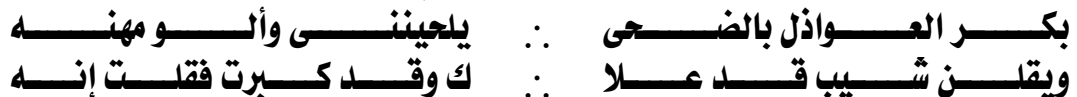

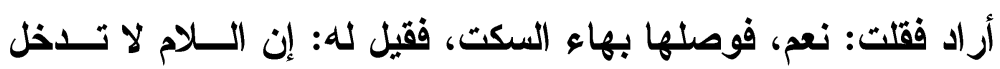

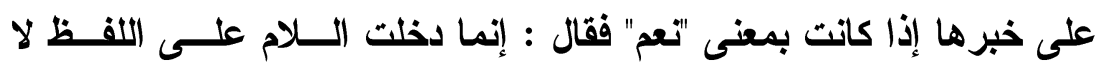


المعنى - والحجة لمن قرأها بالياء ما روى عن عائشة ويحيى بن يعمر :

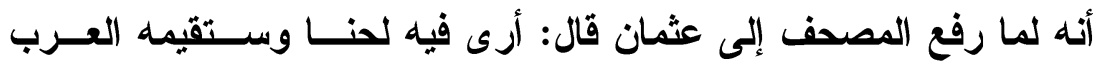
بألسنتها

فإن قيل : فعثمان كان أولى بتغيير اللحن فقل: ليس اللحسن هاهنـــا

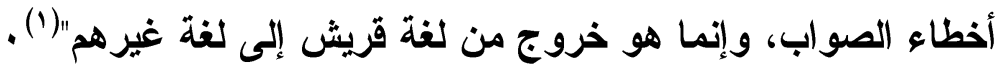

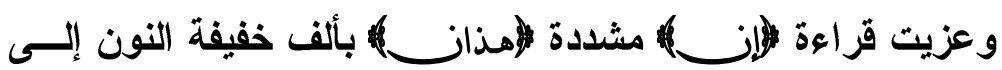
نافع ، وابن عامر، وحمزة، والكسائى، وعاصم فى رواية أبىبكر

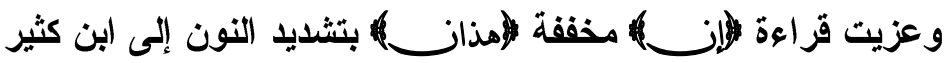

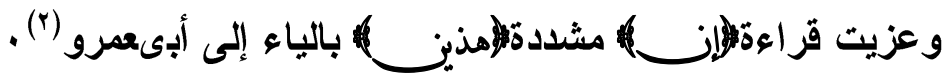

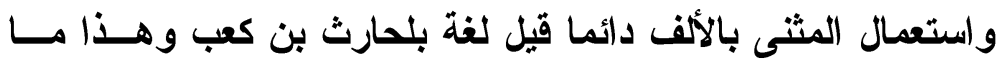

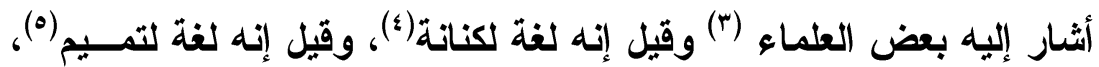
وقيل إنه لبكر بن وائل (ז) .

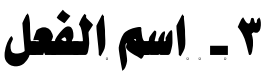

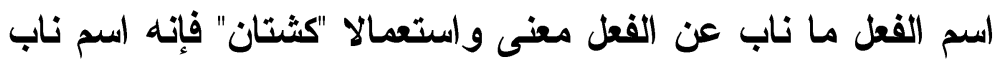

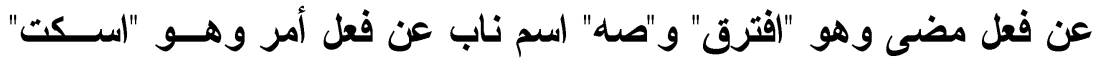

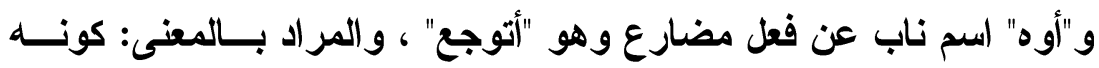

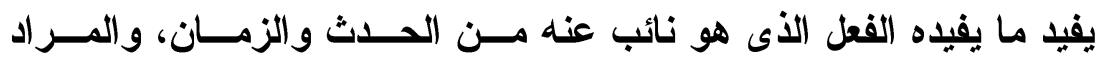

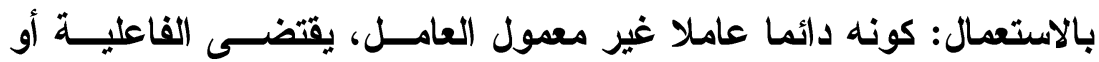

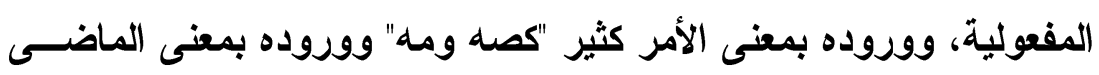

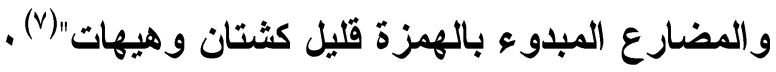

$$
\begin{aligned}
& \text { - (1) الحجة صد (Y) }
\end{aligned}
$$

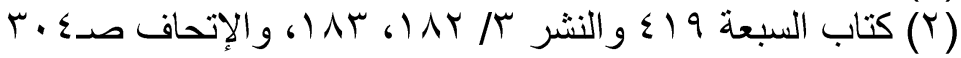

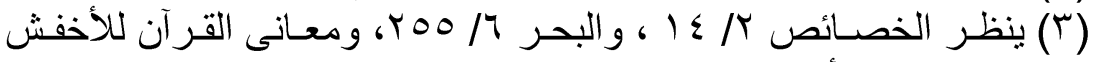

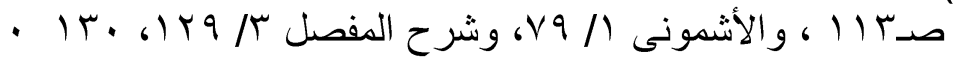

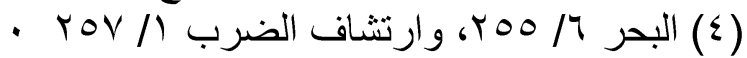

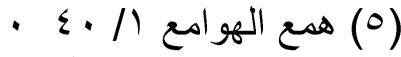

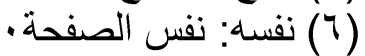

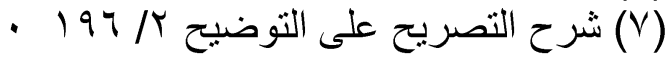


وأسماء الأفعال حكمها غالبا فى التعدى واللزوم وغيرهما كإظهــار

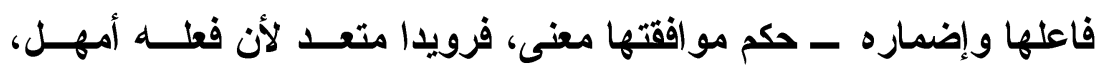

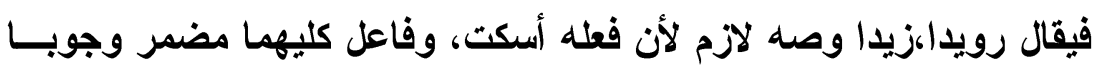

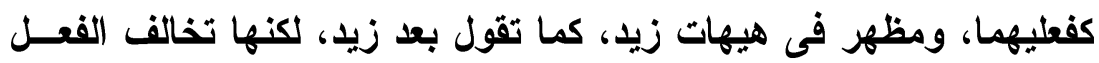

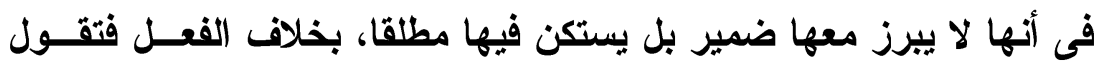

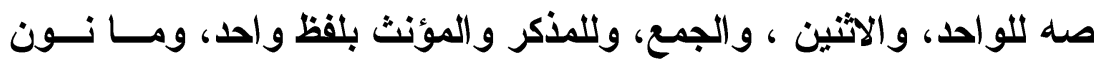

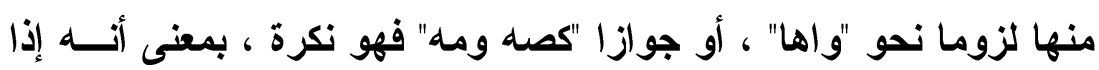

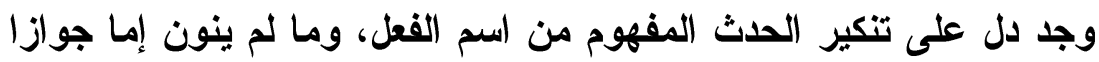

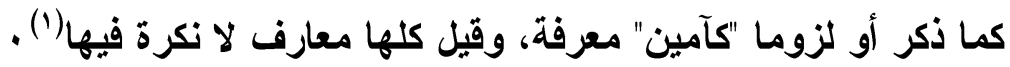

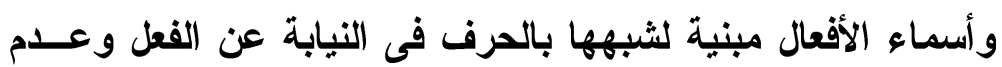

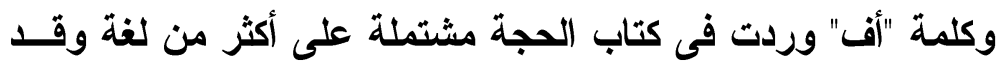
جاء ذللك فى الموضع الآتى:

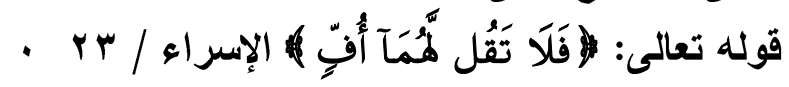
يقول ابن خالويه : "يقرأ بالكسر منونا وغير منون، وبــالفتح مــن

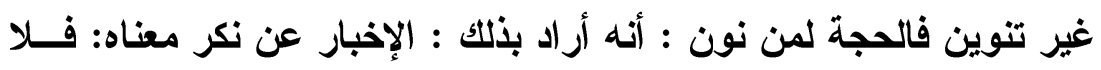

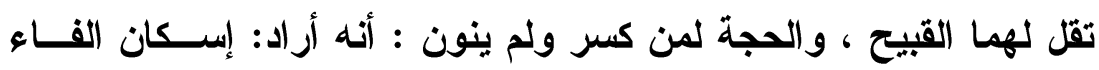

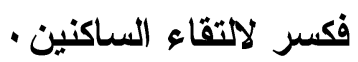

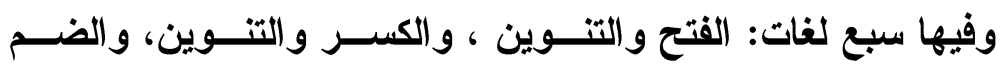

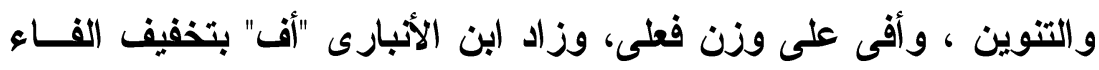

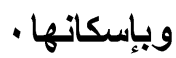

وهى كلمة تقال عند الضجر، ولو علم الله تعالى أوجز منها فى ترك

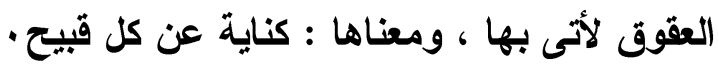




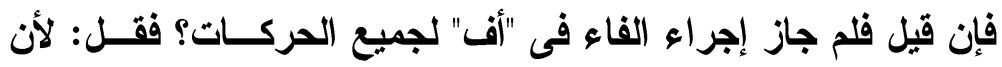

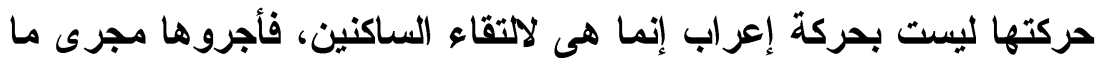

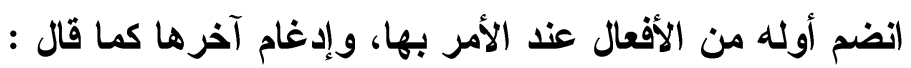

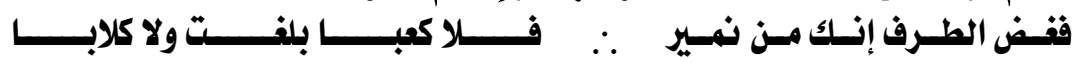

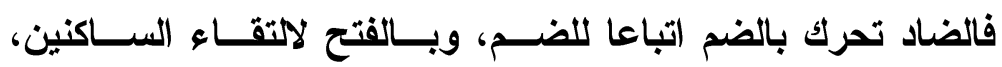

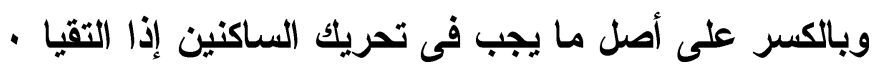

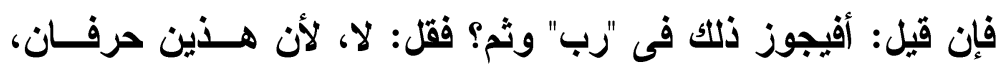

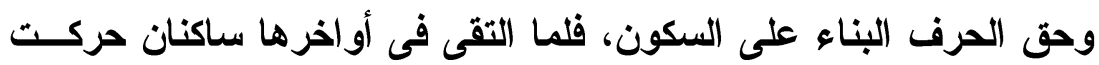

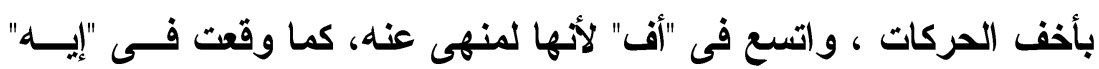

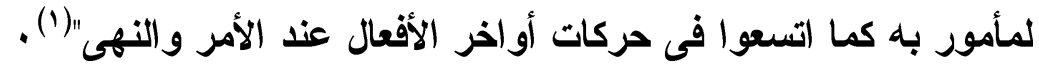

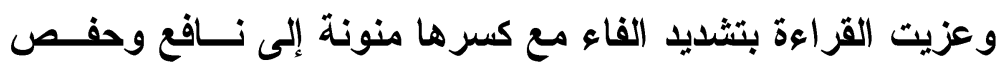

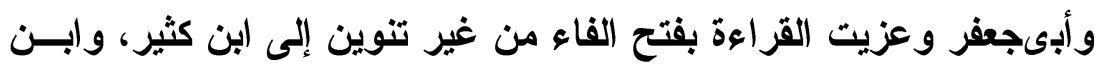

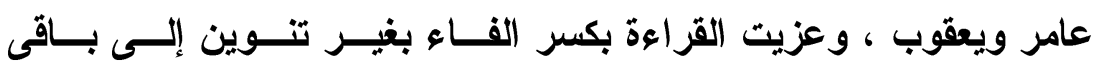

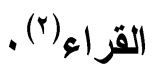
ولغة الحجاز الكسر بالتنوين وعدمه، ولغة قيس الفتح(ז) وأثمار (بن

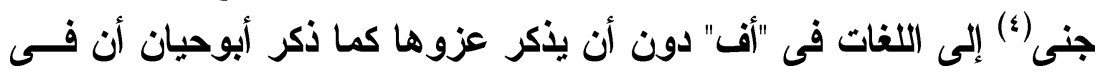

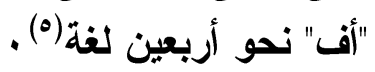

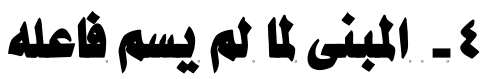

مما لا شك فيه أن هناتك تغييرات تحدث في الجملة حين تتحول مــن

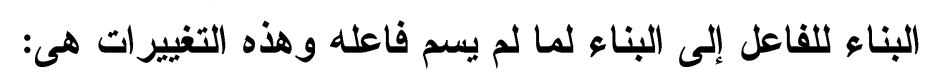

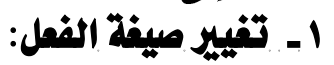

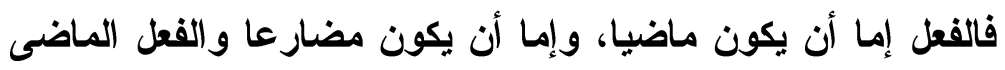

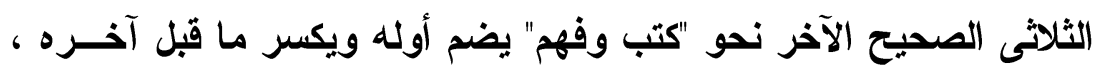

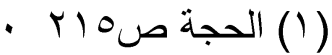

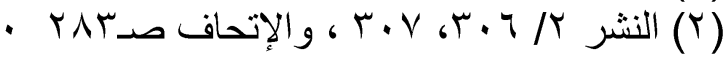

$$
\begin{aligned}
& \text { - (r) الإتحاف صد (r) }
\end{aligned}
$$

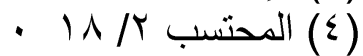

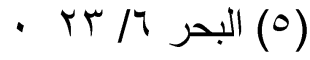


و الماضى المبدوء بتاء مطاوعة بضم أوله وثانيه ويكسر ما قبل آخره نحو

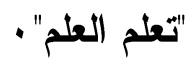

والمبدوء بهمزة وصل يضم أوله وثالثه ويكسر ما قبل آخره نحــو:

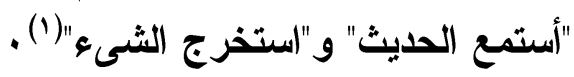
و الماضى الثلاثى الأجوف نحو "قال وباع" فئهيه ثُلاث لغات:

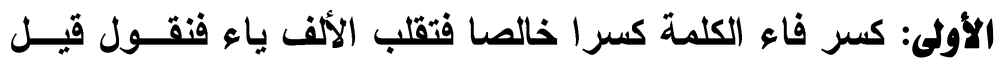

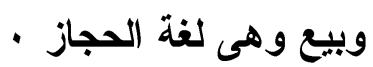

الثانية: إثمام الكسرة الضم وهى لغة كثير من قيس وعامة أسد .

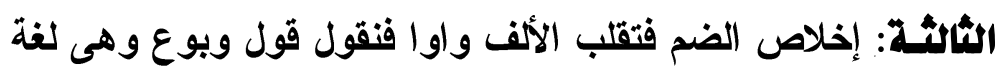
هذيل، وفقعس، ودبير وهما من فصحاء بنى أسد .

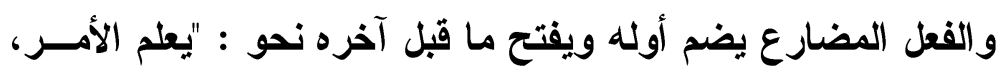

$$
\begin{aligned}
& \text { ويكرم الرجل"(^) . } \\
& \text { r ـ ـ حذف الفاعل: }
\end{aligned}
$$

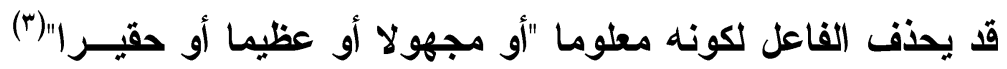

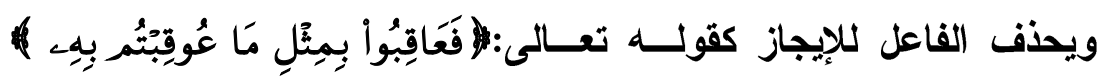

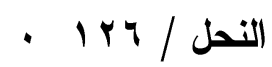
وإصلاح السجع كقولهم: "من طابت سريرته حمدت سيرته" فإنه لو لو لو لوني

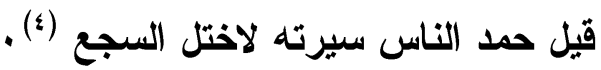

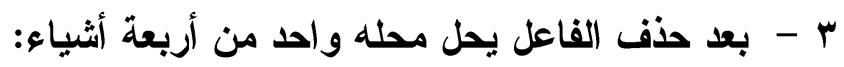

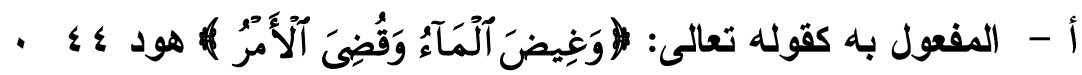

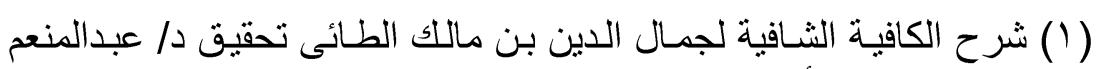

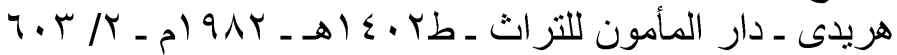

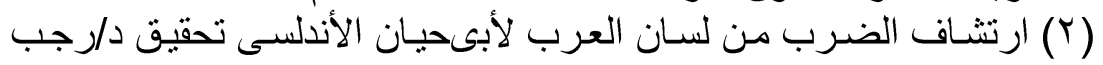

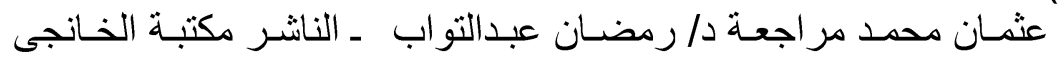

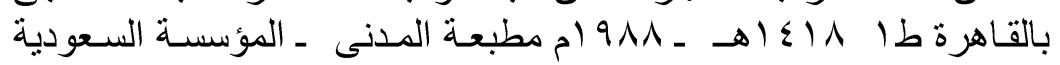

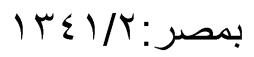

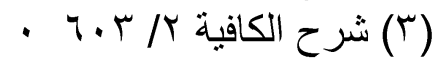

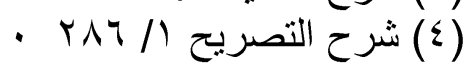


ب - المصدر بشرط أن يكون متصرفا مختصــا كقولـهـ تعـالى :

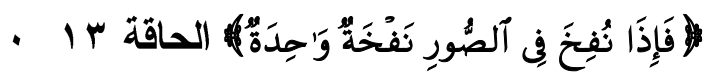

جـ - ظرف الزمان و المكان بشرط أن يكون متصرفا مختصا نحو

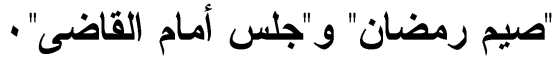

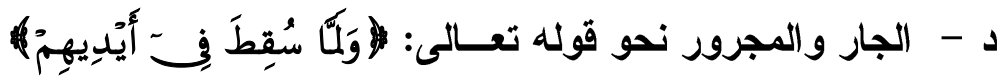

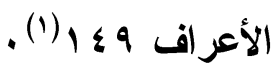

وضم أول الفعل المبنى للمجهول "لأن الضم من علامــات الفاعـل،

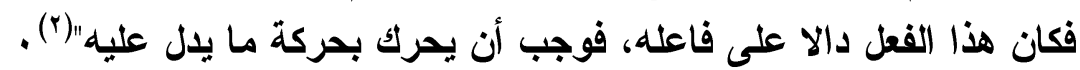

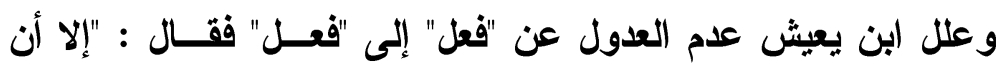

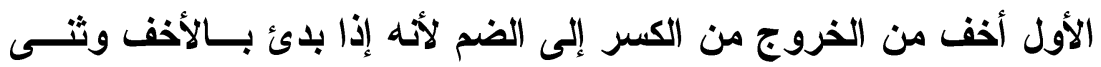

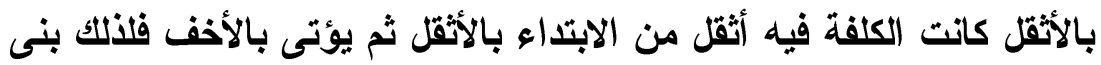

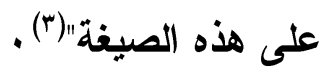
وبتتبع اللهجات الواردة فى كتاب الحجة وجدت كلمات ذكرت بالبناء للفاعل، وبالبناء لما لم يسم فاعله وهذه الكلمات هي:

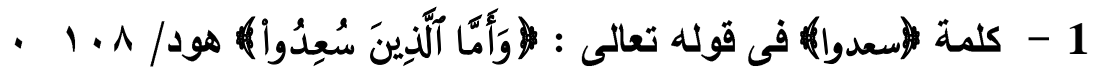

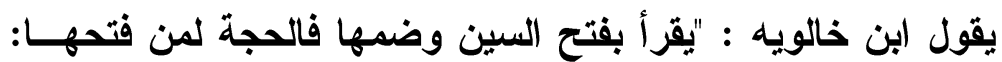

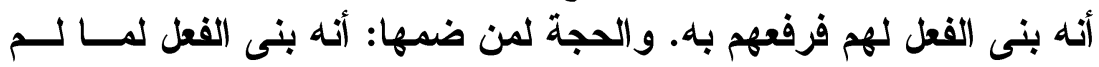

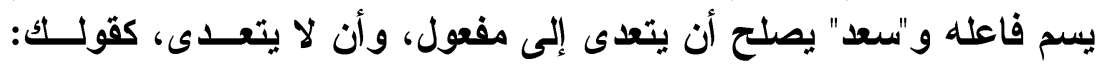

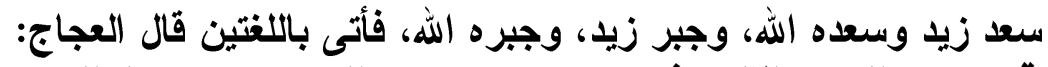

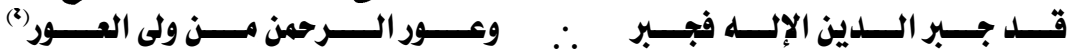

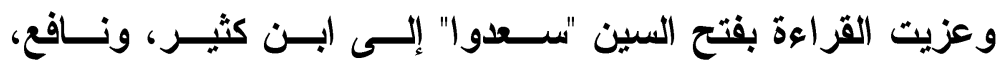

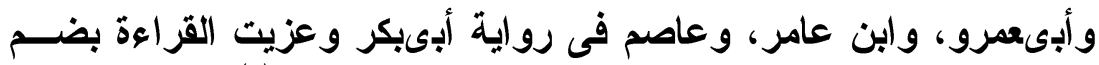

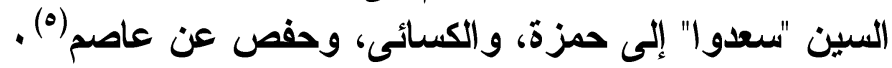

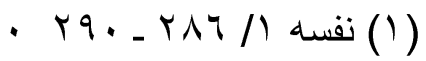

- V) N شرح المفصل (Y)

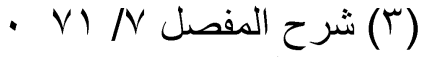

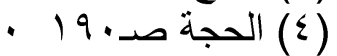

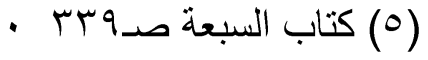




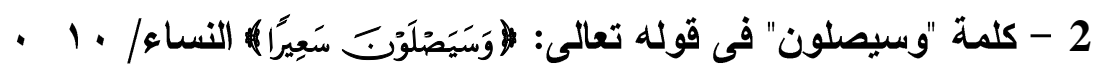

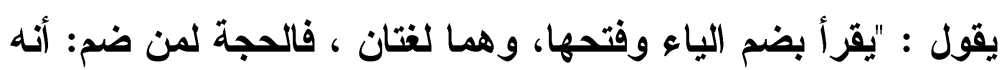

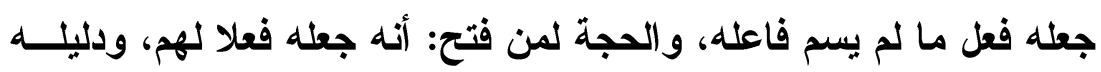

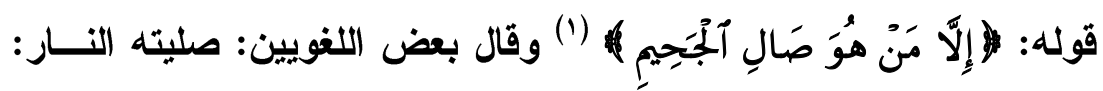

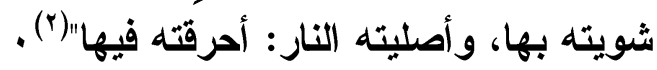

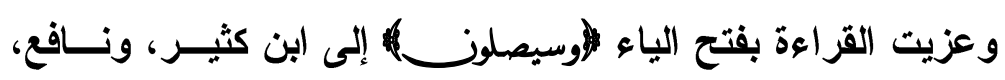
و وأبعمدرو، وحمزة، و الكسائى .

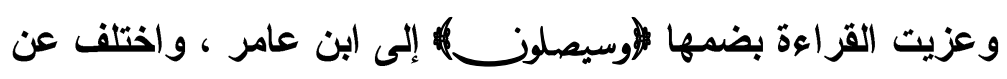

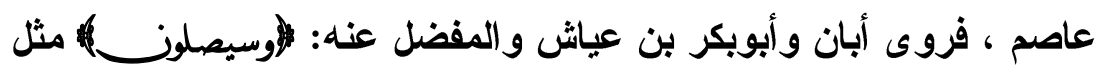

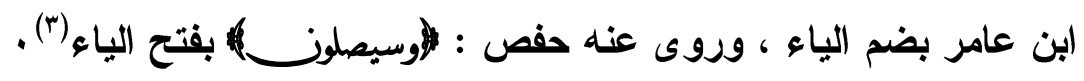

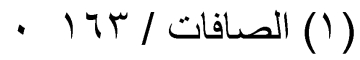

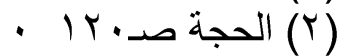

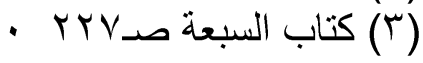




\section{الخاتمة}

لقد أسفر البحث فى هذا الموضوع عن النتائج التالية:

1- فضل ابن خالويه لهجات على أخرى •

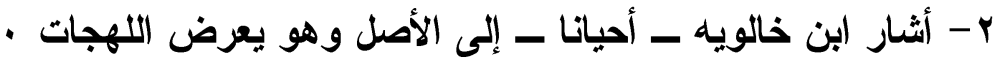

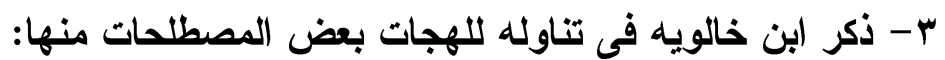

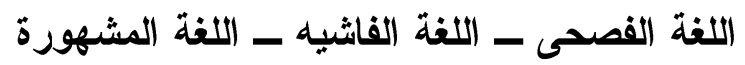

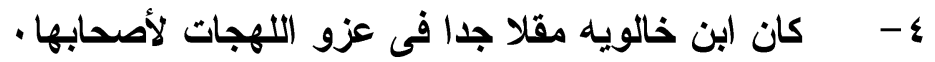

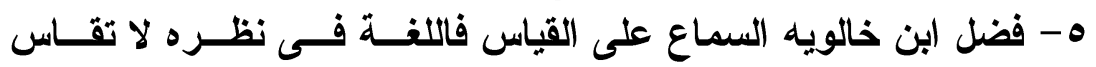

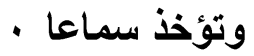

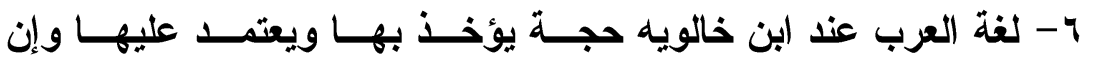

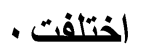

V- من منهج ابن خالويه فى كتابه الحجة أن القرآن الكريم لا يحمل على الفى

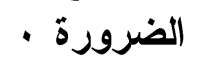

^- كان ابن خالويه فى الحجة مستقل التفكير ، متحرر النزعة لا يتعصب

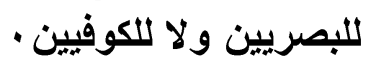

9- ذكر ابن خالويه كثيرا من القراءلات دون ذائن ذكر أصحابها إيمانا بالإيجاز

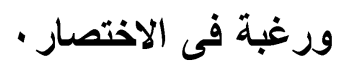

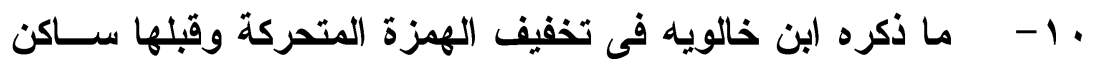

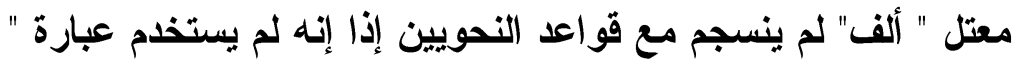

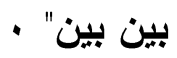

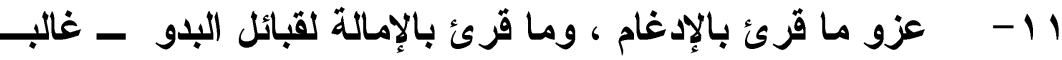

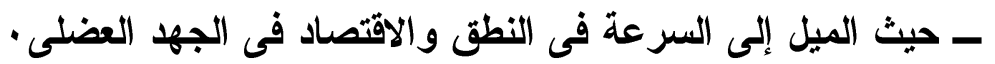

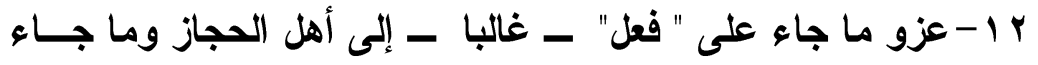

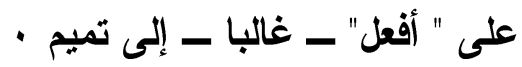

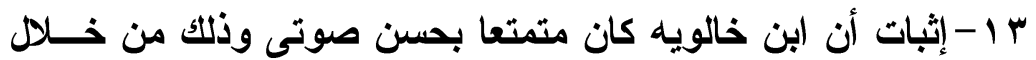

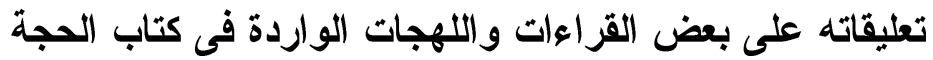
وفى ختام هذا البحث نقول : هذا ما تم التوصل إليه من نتائج فى هذاب

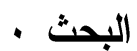

وصل الهم على سيدنا محمد وعلى آله وصحبه وسلم وآخر دعوانا أن الن آله

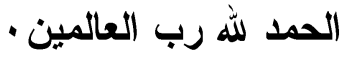




\section{فهرس المصادر والمراجع}

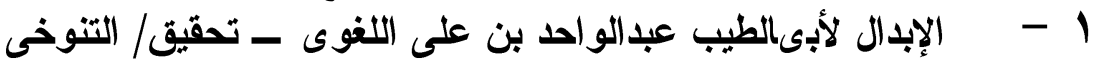

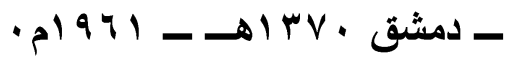

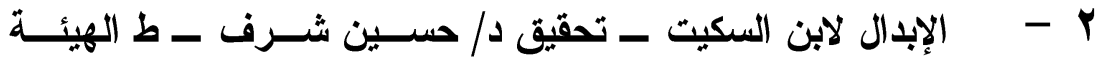

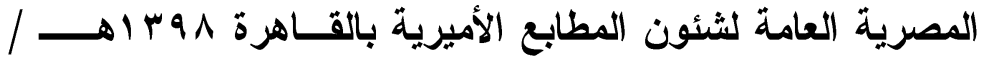

$$
\text { - } 9 \text { 1 } 9 \text { 人 }
$$

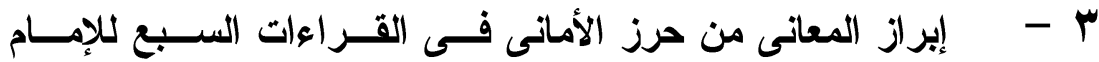

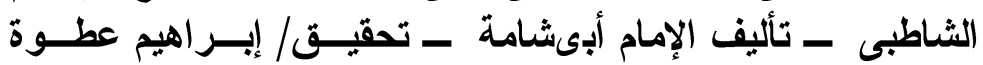

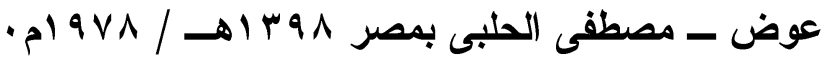

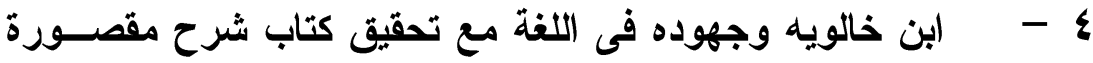

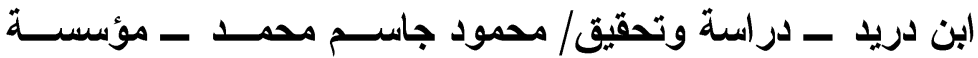

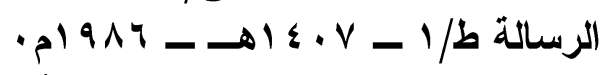

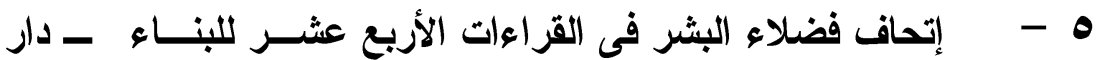

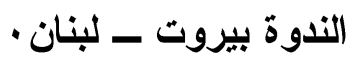

7

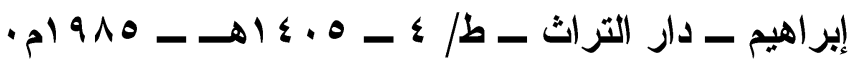

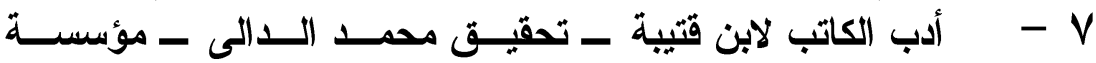

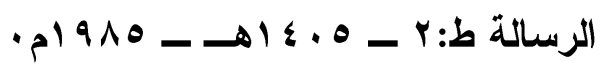

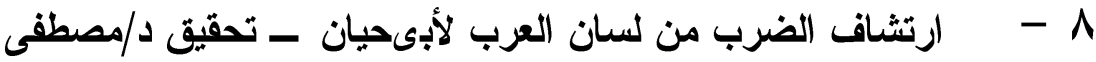

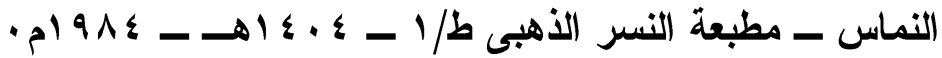
، - - 9

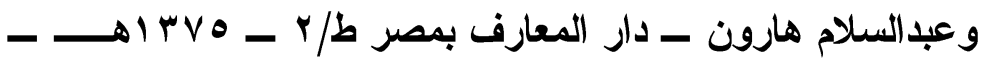
-

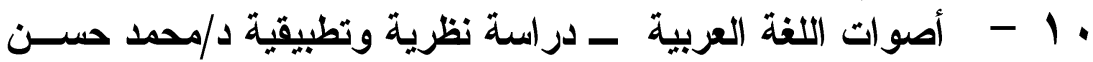

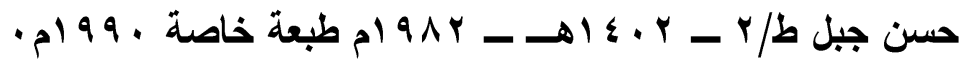

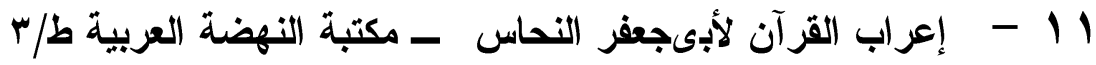

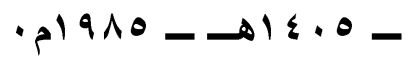

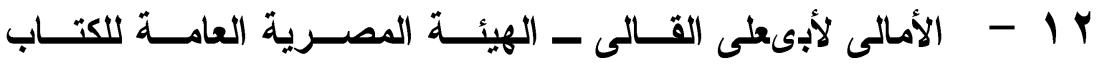
- 9 -

rا

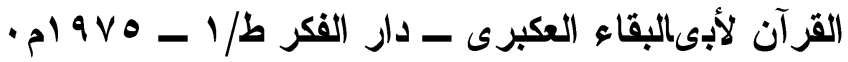




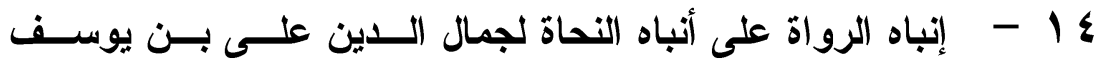

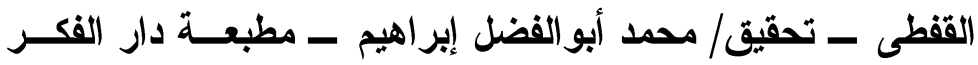

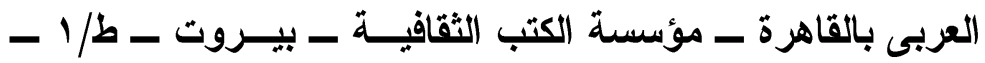

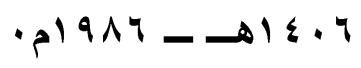

10

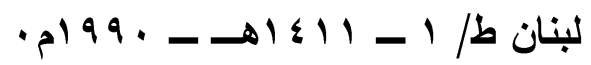

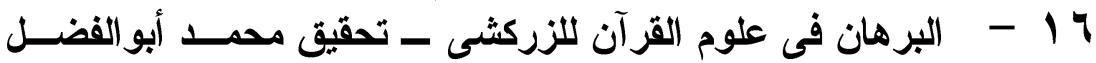

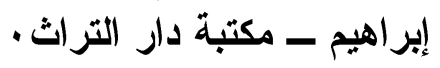

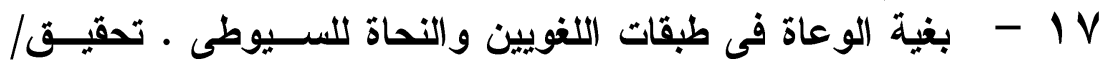

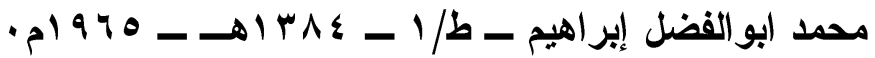

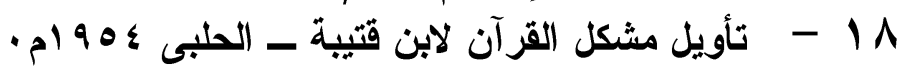

19

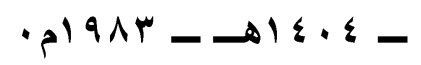

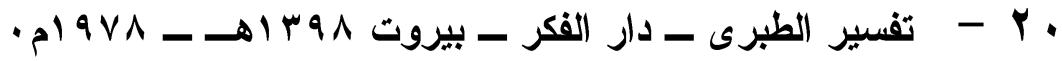

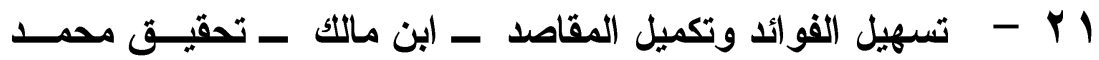

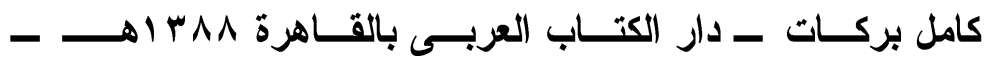

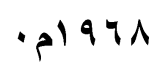

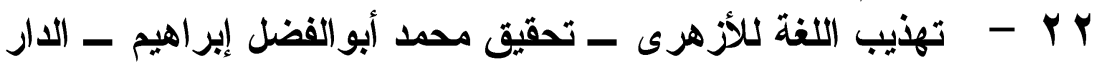

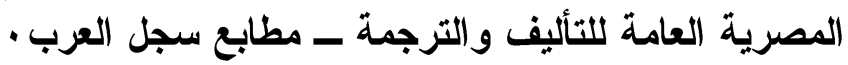

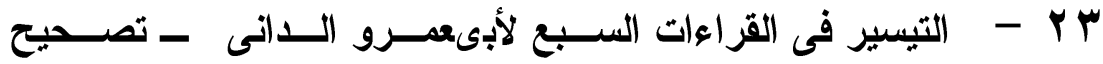

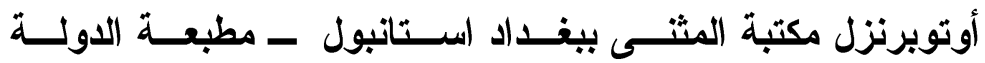

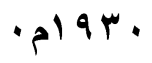

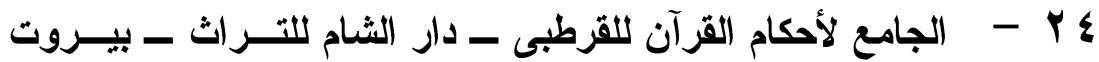

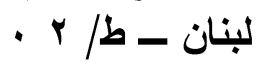

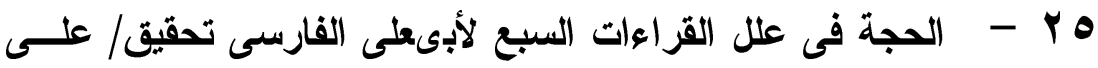

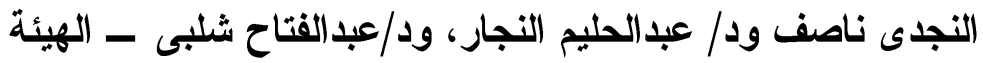

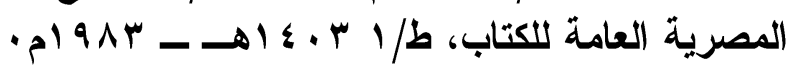

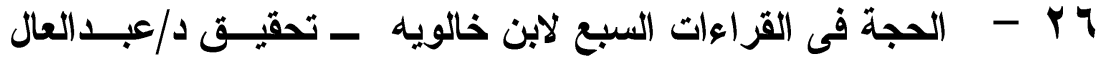

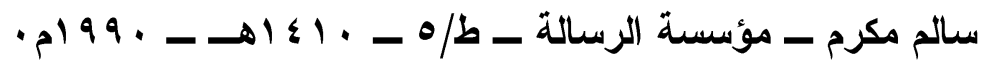

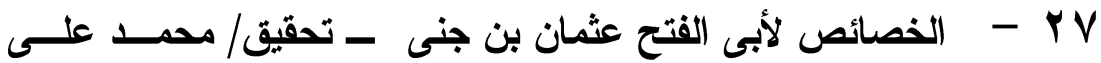

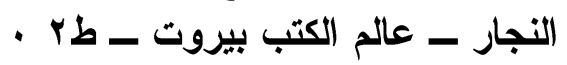




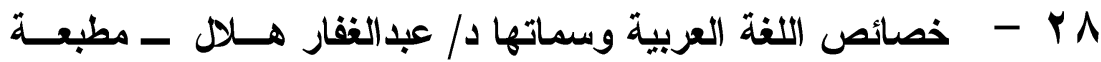

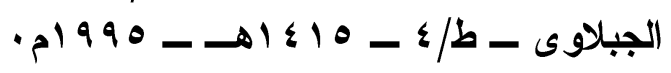

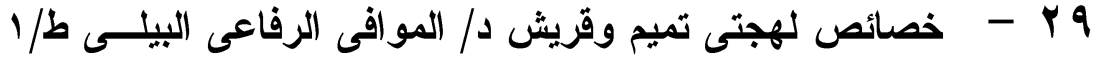
- $19 \wedge \mathrm{V}-$

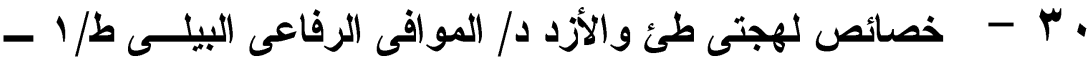

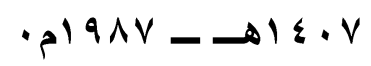

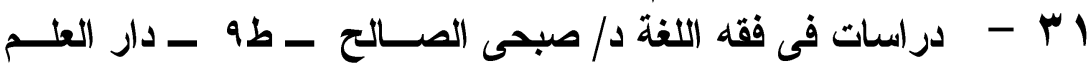

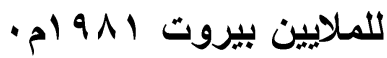

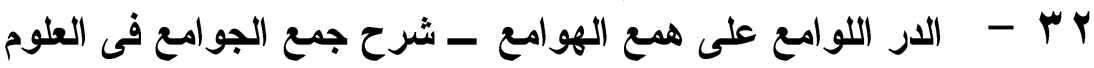

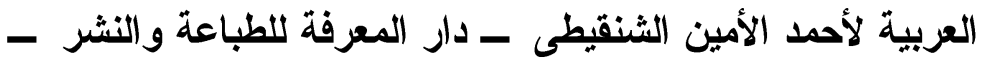

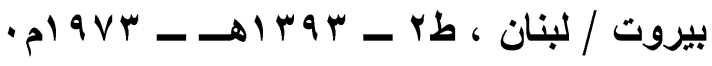

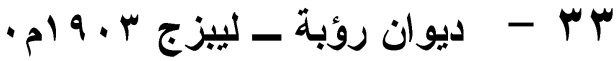

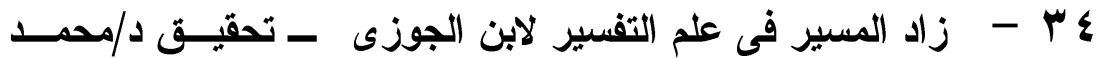

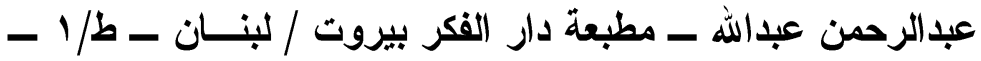

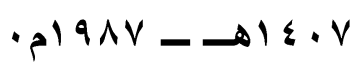

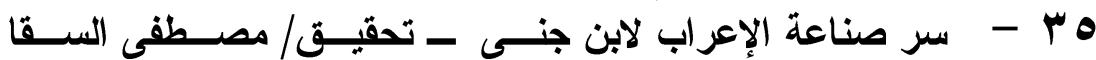

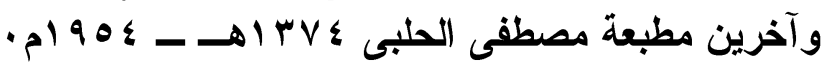

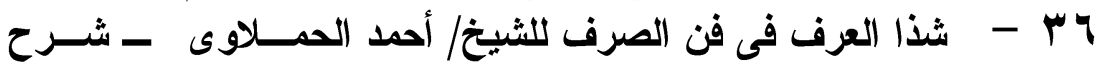

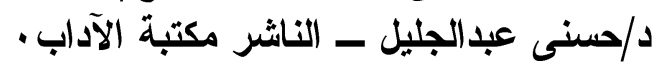

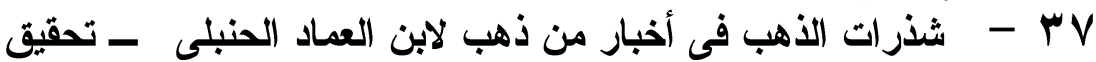

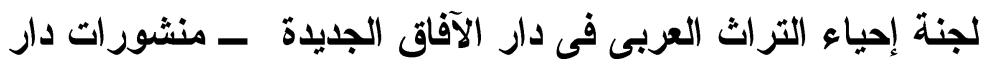

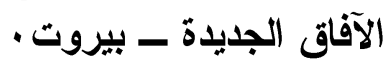

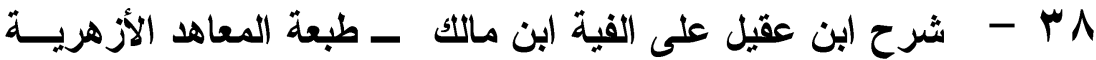

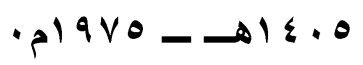

q - - شرح الأشمونى على ألفية (بن مالك ، ومعه حاثية الصــبان ط

$$
\text { عيسى الحلبى الأنونى }
$$

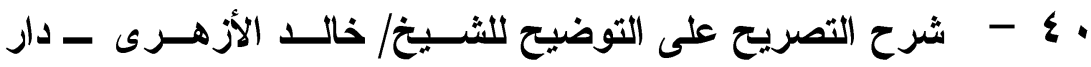

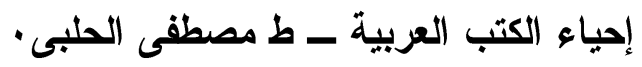

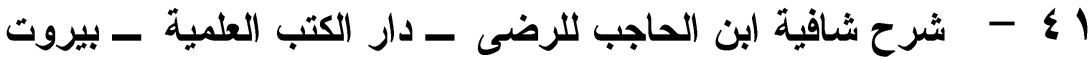

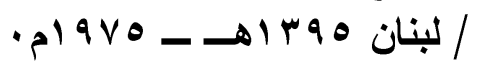




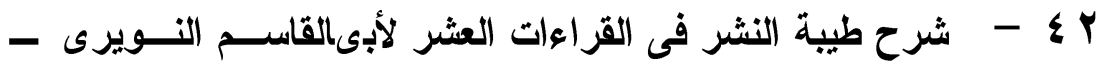

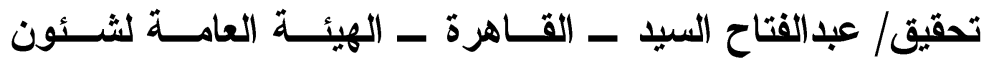

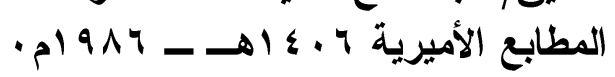

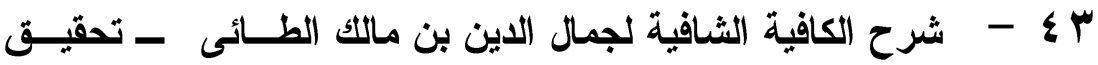

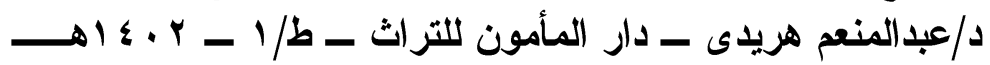

$$
\text { - } 19 \wedge r-
$$

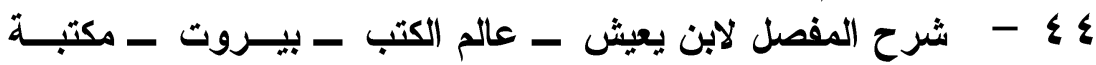

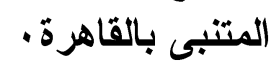

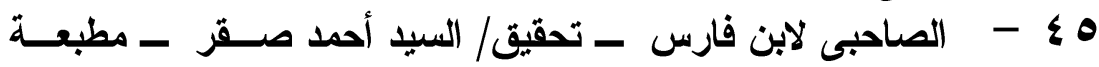

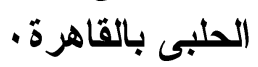

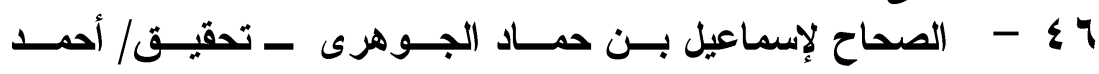

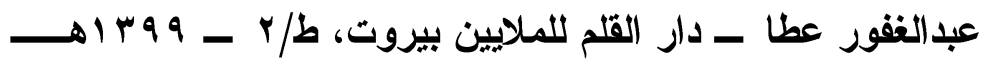

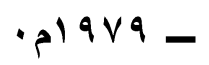

\&V

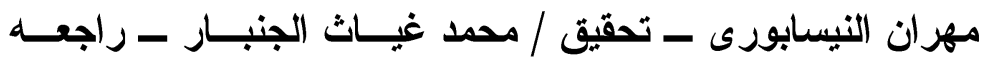

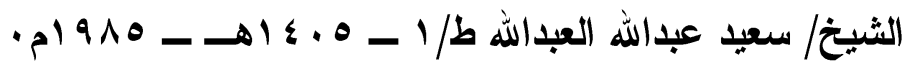

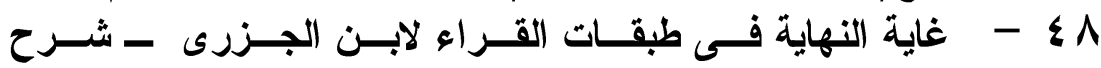

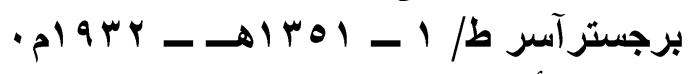

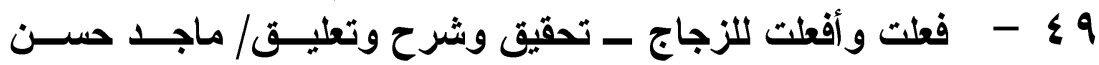

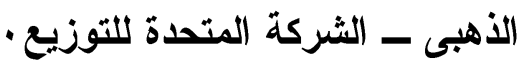

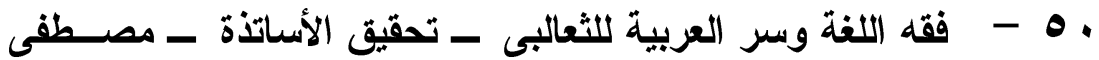

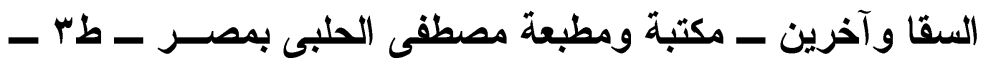

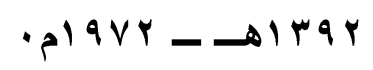

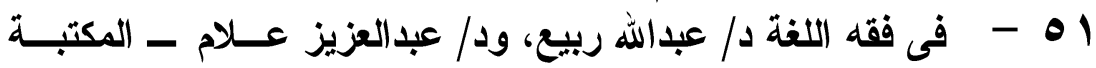

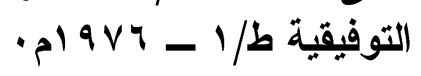

r - م فى اللهجات العربية د/ إبراهيم أنيس - مكتبة الأنجلو المصرية

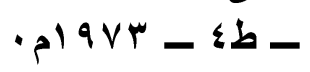

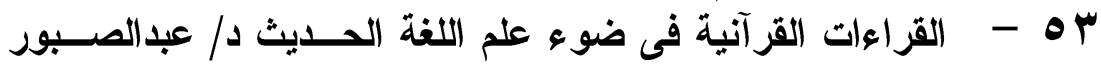

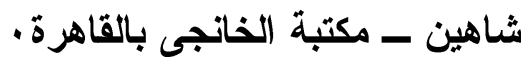

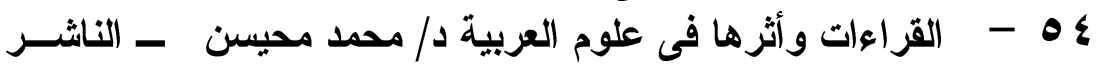

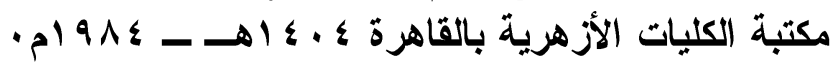


هـ - القراءات واللهجات فى تفسير زاد المسير فى علم التفسير لابـن

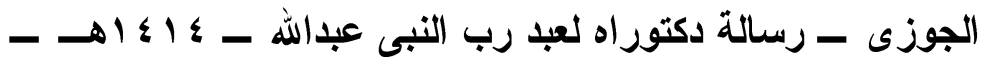

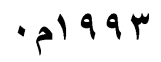

צ ه - الكتاب لسبيويه ـ مكتبة الخانجى بالقاهرة، ودار الرفــاعى ودار

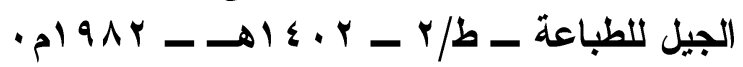

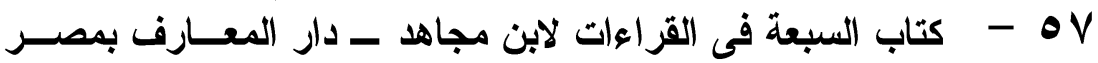

$$
\text { - } r / b
$$

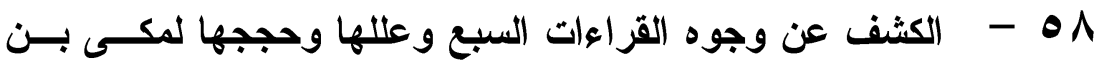

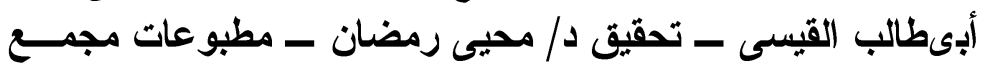

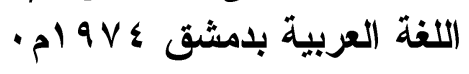

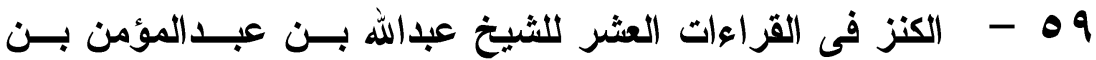

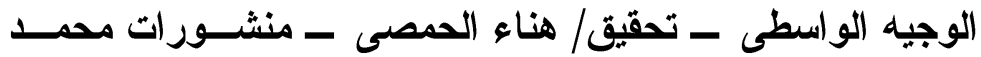

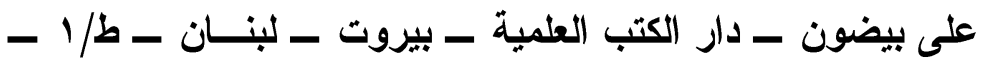

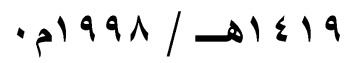

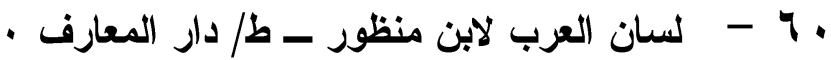

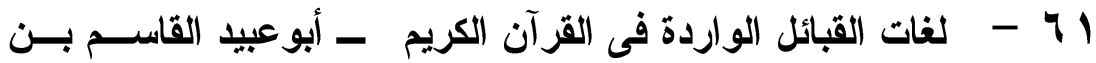

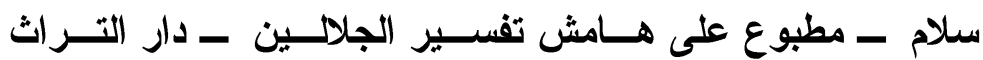

$$
\text { - } 9 \mathrm{VV}
$$

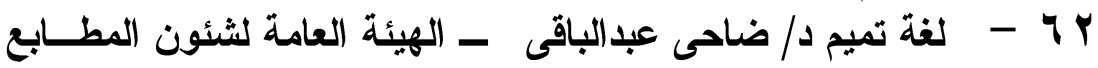

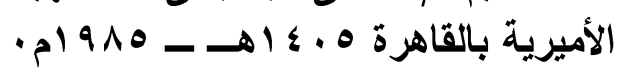

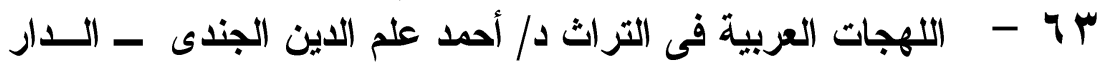

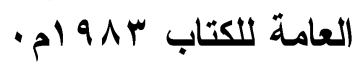

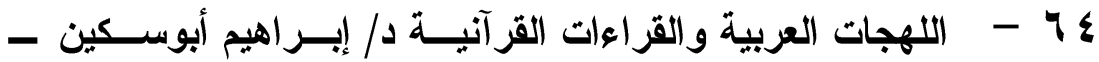

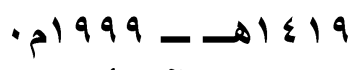

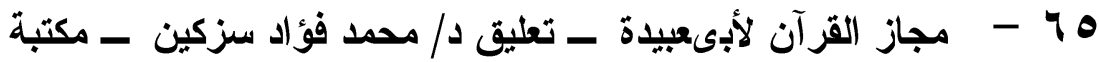

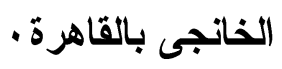

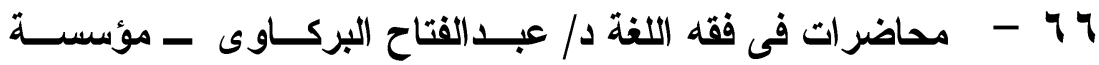

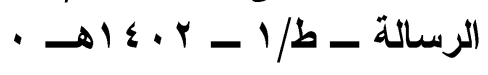

- IV

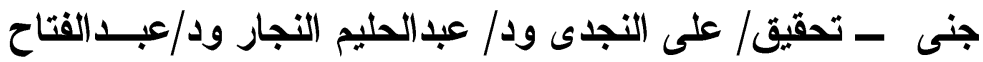




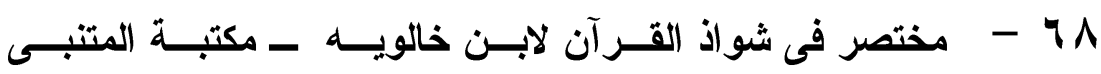
بالقاهرة.

- 99

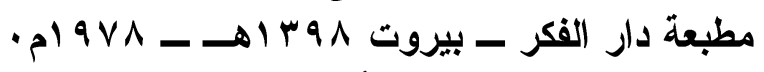

- V.

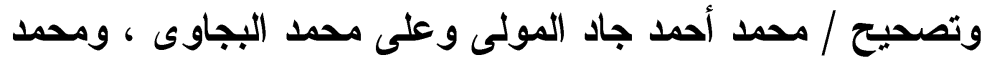

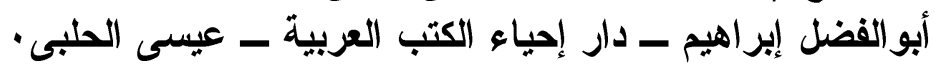

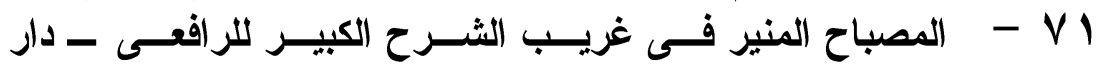
المعارف - المعناح

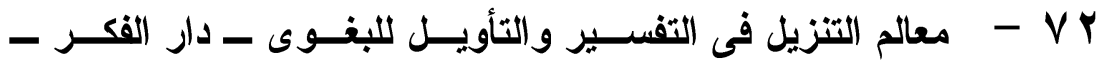

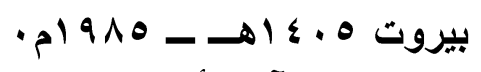

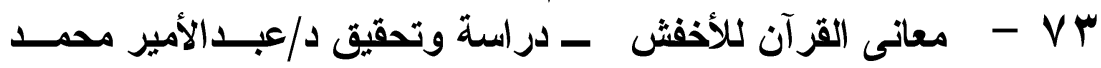

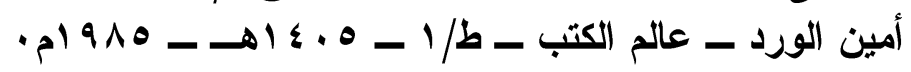

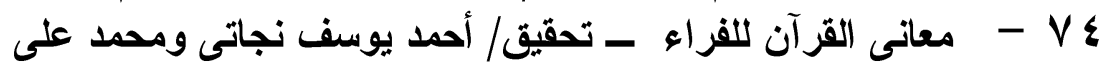

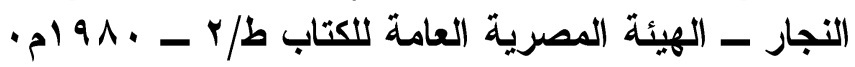

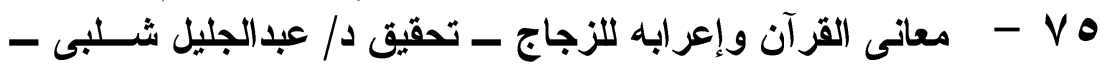

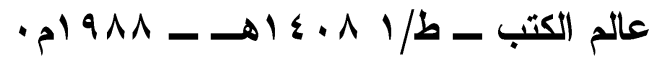

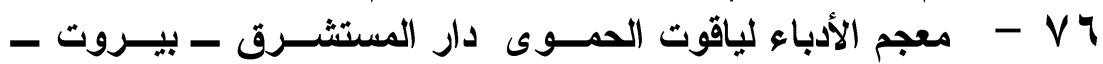
لبنان - لبعم

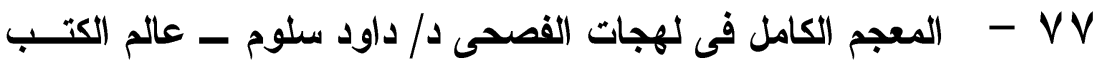

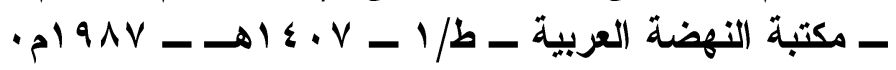

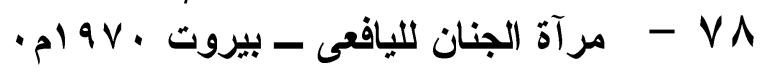

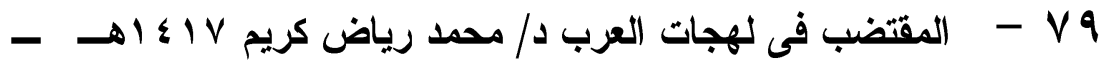
- 1997

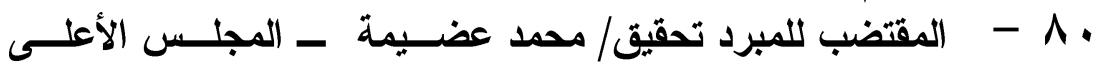

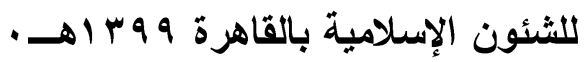

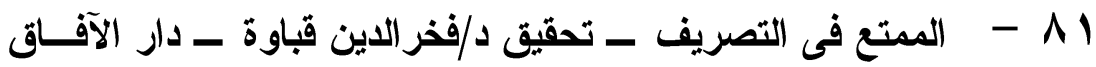

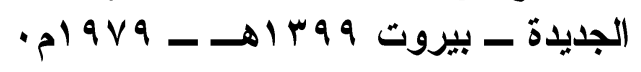

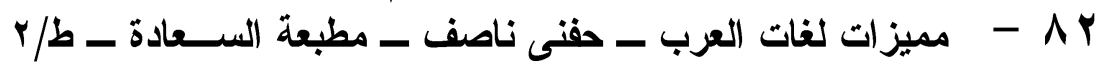
بمصر • بrاוهـ. 


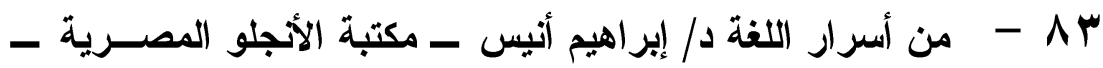

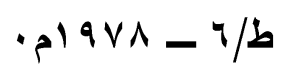

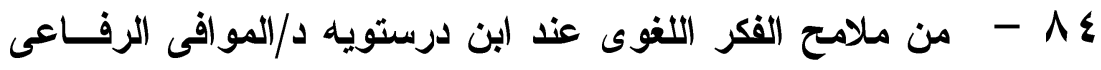

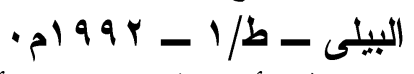

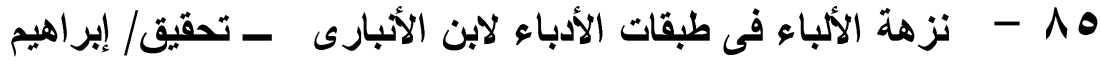

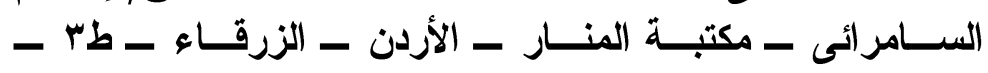

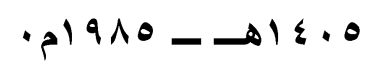

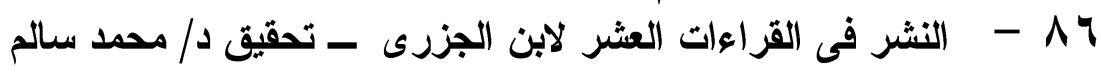

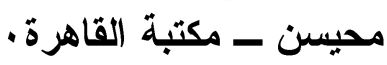

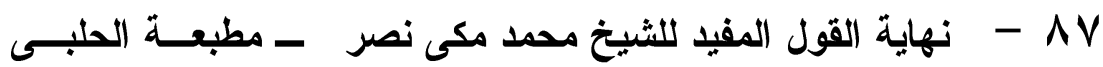
צ 9 كاية الهـ

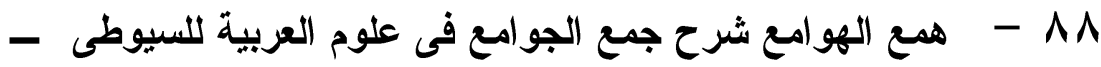

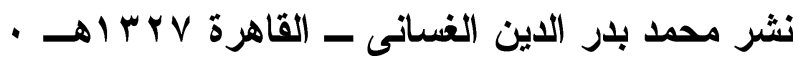

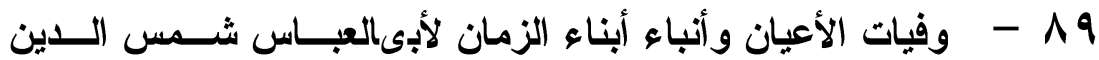

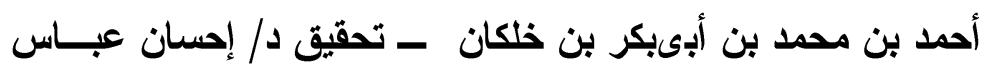

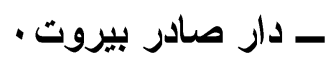

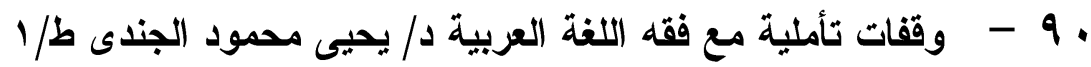

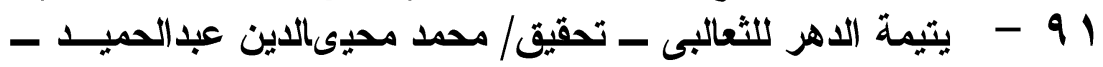

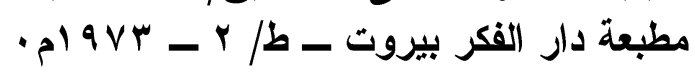

